UNIVERSIDADE DE SÃO PAULO

FACULDADE DE FILOSOFIA, LETRAS E CIÊNCIAS HUMANAS

DEPARTAMENTO DE LETRAS MODERNAS

PROGRAMA DE PÓS-GRADUAÇÃO EM LÍNGUA E LITERATURA ALEMÃ

André Luiz Ming Garcia

\title{
PROGRESSÃO DE TÓPICOS GRAMATICAIS EM CURSOS DE ALEMÃO LÍNGUA ESTRANGEIRA: ESTUDO EMPÍRICO DE PROCESSOS DE ENSINO-APRENDIZAGEM
}

Dissertação apresentada à banca examinadora do Departamento de Letras Modernas da Faculdade de Filosofia, Letras e Ciências Humanas da Universidade de São Paulo como requisito parcial para a obtenção do título de Mestre em Letras.

Área de concentração: Língua e Literatura Alemã

Orientador: Prof. Dr. Helmut Paul Erich Galle

São Paulo

2014

- exemplar revisado - 
UNIVERSIDADE DE SÃO PAULO

FACULDADE DE FILOSOFIA, LETRAS E CIÊNCIAS HUMANAS

DEPARTAMENTO DE LETRAS MODERNAS

PROGRAMA DE PÓS-GRADUAÇÃO EM LÍNGUA E LITERATURA ALEMÃ

André Luiz Ming Garcia

\section{PROGRESSÃO DE TÓPICOS GRAMATICAIS EM CURSOS DE ALEMÃO LÍNGUA ESTRANGEIRA: ESTUDO EMPÍRICO DE PROCESSOS DE ENSINO-APRENDIZAGEM}

Dissertação apresentada à banca examinadora do Departamento de Letras Modernas da Faculdade de Filosofia, Letras e Ciências Humanas da Universidade de São Paulo como requisito parcial para a obtenção do título de Mestre em Letras.

Área de concentração: Língua e Literatura Alemã

Orientador: Prof. Dr. Helmut Paul Erich Galle

De acordo,

São Paulo

2014

- exemplar revisado - 
Prof. Dr. Marco Antonio Zago

Reitor da Universidade de São Paulo

Prof. Dr. Sérgio França Adorno de Abreu

Diretor da Faculdade de Filosofia, Letras e Ciências Humanas

Prof. Dr. Francis Henrik Aubert

Chefe do Departamento de Letras Modernas

Prof. Dr. Helmut Paul Erich Galle

Coordenador do Programa de Pós-Graduação em Língua e Literatura Alemã 
Nome: André Luiz Ming Garcia

Título: Progressão de tópicos gramaticais em cursos de alemão língua estrangeira; estudo empírico de processos de ensino-aprendizagem

Dissertação apresentada à Faculdade de Filosofia, Letras e Ciências Humanas da Universidade de São Paulo com vistas à obtenção do título de Mestre em Letras.

Área de Concentração: Língua e Literatura Alemã.

Aprovado em:

/ 2014.

Banca Examinadora:

Prof(a). Dr(a). Instituição:

Julgamento: Assinatura:

Prof(a). Dr(a). Instituição:

Julgamento: Assinatura:

Prof(a). Dr(a). Instituição:

Julgamento: Assinatura: 
Para minha mãe,

'força que nunca seca'

Para minhas irmãs,

tão dadas a acreditar em mim

Para meus amigos,

família escolhida 


\section{AGRADECIMENTOS}

Expresso meus mais sinceros agradecimentos e minha estima, creditando assim a fundamental presença do outro, intelectual e afetivamente, na construção desta pesquisa:

Ao Prof. Dr. Helmut Galle, pela acolhida, pela ética profissional e acadêmica, pela liberdade de pesquisa concedida e pela constante e característica gentileza;

À Prof ${ }^{a} \operatorname{Dr}^{a}$ Dörthe Uphoff e à Prof ${ }^{a}$ Dr $^{a}$ Eliane Lousada, pelas valiosas apreciações de meus manuscritos durante o exame de qualificação, pelos saberes que tão gentilmente foram compartilhados comigo ao longo do caminho, pelo seu rigor acadêmico e generosidade;

Aos professores doutores que amavelmente aceitaram participar da banca de defesa: Prof. Dr. Aleksandar Jovanovic, que me introduziu aos estudos da didática e metodologia de ensino de língua estrangeira; $\operatorname{Prof}^{\mathrm{a}} \operatorname{Dr}^{\mathrm{a}}$ Dörthe Uphoff, que abrilhantou a banca de qualificação; Prof $^{\mathrm{a}}$ Dr $^{\mathrm{a}}$ Maria Helena Battaglia que, além de alemão, me ensinou didática; Prof. Dr. Henrique Janzen e $\operatorname{Prof}^{a} \operatorname{Dr}^{a}$ Maria Cristina Evangelista, que tão amavelmente se prontificaram a atuar como suplentes;

À minha grande amiga, companheira, colaboradora e incentivadora Érica de Freitas, meu muito amor;

À minha estimada amiga e mestra, Cristina Shibuya, do Goethe-Institut São Paulo, com quem várias vezes reaprendi a arte de ensinar;

Não poderei mencionar, neste curto espaço, todos os meus queridos amigos, que cultivei ao longo dos anos e que com tanta compreensão perdoa(ra)m meus sumiços - a eles, em conjunto com minha família, dedico este trabalho. De forma específica, porém, necessito lembrar aqueles que de alguma forma participaram ativamente deste processo, quer seja pela torcida, quer seja pela presença acalentadora em momentos difíceis: Daniela Prado e Laura Prado (minhas irmãs que não são irmãs), Rogério Fraulo, meu tão querido irmão, Cristiana Menezes, Daiana Dalfito, Cátia Mezalira, Regina Souza, Regina de Andrade e Priscilla Nascimento; 
Aos hoje amigos e ex-colegas de trabalho com quem passei momentos saborosos, Stefan Dudovitz, Carla Koch e Ana Barreto, pela colaboração generosa - sem vocês, este trabalho nada seria;

A Aline Abreu, que tanto admiro, por me ajudar a visar o futuro com cores, traços, formas, texturas, dimensões, doces palavras e todo o êxtase da verbovisualidade;

À querida e admirada $\operatorname{Prof}^{\mathrm{a}} \operatorname{Dr}^{\mathrm{a}}$ Maria dos Prazeres Mendes, pelas oportunidades que me ofereceu durante o estágio PAE, permitindo-me olhar, a partir de dentro, para o processo de ensino-aprendizagem no âmbito universitário, e pelas incontáveis e incomparáveis referências e (re)leituras do poético no mundo;

Aos funcionários do DLM e do Serviço de Pós-Graduação da FFLCH/USP, em especial Fátima e Edite, pela prontidão em ajudar na resolução dos não poucos pepinos burocráticos que, em certos momentos, eram tão molestos que não me permitiam concentrar-me apenas na dissertação. Nada foi fácil, tudo deu certo;

Aos meus alunos e ex-alunos, razão pela qual decidi refletir um pouco mais longamente sobre o ensino-aprendizagem dessa Fremdsprache, língua bela, mas estranha e estrangeira;

À CAPES, pelo financiamento da pesquisa, que foi fundamental e viabilizou a confecção deste trabalho;

E a todos aqueles amigos fisicamente ausentes durante este processo. Levarei sempre algo de vocês em mim, sendo-o-outro nestes caminhos de (des)aprender e (des)esquecer.

I've looked at life from both sides, now

From up and down and still somehow

It's life's illusions I recall

I really don't know life at all

Joni Mitchell, 1969, “Both Sides, Now”, in Clouds 


\section{RESUMO}

Neste trabalho, a partir de uma proposta de investigação híbrida, ao combinar elementos da pesquisa quantitativa aos da qualitativo-interpretativista, e com base em arcabouços teóricos advindos da área de alemão língua estrangeira e psicolinguística, entre outras, procura-se comparar os produtos do ensino-aprendizagem de alunos brasileiros de alemão língua estrangeira que aprendem as orações relativas do alemão a partir das propostas de progressão de tópicos gramaticais sintética e analítica, assim como descritas por Wilkins (1978). Para tal, realizaram-se coletas de dados junto a aprendentes que tiveram contato com as orações relativas alemãs em meio institucional, onde se adotava os livros didáticos Schritte International 5 e studio $d$ A2. Considera-se que o ensino de tópicos gramaticais em blocos, com a transmissão de grandes volumes de informação de uma só vez, como na abordagem analítica e mediante o emprego de Schritte, possa gerar uma sobrecarga da memória de trabalho dos aprendizes, enquanto que o ensino da gramática em fases ou ciclos, a partir da abordagem sintética, permita o depósito paulatino de informações na limitada memória de trabalho (e de curta duração), com a possibilidade de que dados se assentem na memória de longa duração e possam ser acessados quando do depósito de novos dados relacionados. $\mathrm{O}$ trabalho confirma a hipótese inicial de que ambas as perspectivas, ao apresentarem seus bônus e ônus, conduzem a resultados semelhantes no processo de ensino-aprendizagem. Adotandose a tipologia de exercícios de Neuner et al. (1981), influente na área de alemão língua estrangeira, verifica-se a produção dos estudantes em exercícios que oscilam entre os mais reprodutivos e os mais produtivos, constatando-se que a performance dos alunos é superior nos primeiros, quando se avaliam as frases construídas de forma adequada morfossintática e semântico-pragmaticamente. Em resumo, os dados coletados e analisados, de forma geral, não apontam para uma suposta superioridade de uma ou outra abordagem de progressão de tópicos gramaticais em cursos de (alemão) língua estrangeira.

Palavras-chave: alemão como língua estrangeira; ensino-aprendizagem; gramática; livros didáticos; memória; orações relativas. 


\section{ABSTRACT}

In this work, from a proposed hybrid research method, by combining elements of the quantitative and qualitative-interpretative methods, and based on theoretical frameworks coming from the area of German as a foreign language, psycholinguistics etc., we seek to compare the products of teaching and learning German as a foreign language by Brazilian students, based on the proposals of the progression of synthetic and analytical grammatical topics, as described by Wilkins (1978). To this end, we collected data from learners who had contact with the German relative clauses in institutional environment, where two different textbooks were used, Schritte International 5 and studio $\mathrm{d}$ A2. It is considered that the teaching of grammar topics in blocks, with the transmission of large amounts of information at once, as in the analytical approach and by employing Schritte, can generate an overload of the working memory of the learners, while the grammar teaching in phases or cycles, from the syntetic approach, allows the gradual deposit of information in the limited working memory (short term), with the possibility that data be deposited in long-term memory and can be accessed when the deposit of new information occurs. The work confirms the initial hypothesis that both perspectives, in presenting their bonuses and burdens, lead to similar results in the teaching-learning process. Adopting the type of exercises of Neuner et al. (1981), influential in the area of German foreign language, we analyze the production of students in exercises ranging from the most reproductive and more productive, in order to verify if the performance of students is higher in the first, when evaluating sentences constructed appropriately in morphosyntactic and semantic-pragmatic terms. In summary, the collected and analyzed data, in general, do not point a supposed superiority of one of the two approaches to the progression of grammar topics in (German) foreign language courses.

Key words: German as a foreign language; teaching and learning; grammar; textbooks; memory; relative clauses. 


\section{ZUSAMMENFASSUNG}

Ausgehend von einer hybriden Forschungsperspektive vergleicht die vorliegende Arbeit sowohl mit quantitativen als auch qualitativen Methoden, und basierend auf DaF- und psycholinguistischen theoretischen Mustern, die Produkte des Lernprozesses brasilianischer DaF-Lerner, die deutsche Relativsätze auf der Grundlage von syntetischen und analytischen Ansätzen (Wilkins, 1978) erlernen. Hierzu wuden Daten von Lernern gesammelt, die an Sprachenschulen unter Einsatz der Lehrwerke Schritte International und studio d einen Deutschkurs besuchen. Es wird angenommen, dass im Allgemeinen das Lehren von Themen der DaF-Grammatik, bei dem eine Fülle von Informationen parallel vermittelt (analytischer Ansatz, Schritte International) und so das Arbeitsgedächtnis überlasten kann; Im Gegensatz dazu kann das Grammatiklehren aus einer zyklischen Perspektive (syntektischer Ansatz, studio d) das sukzessive Speichern von Informationen im begrenzten Arbeits- bzw. Kurzzeitgedächtnis unterstützen, sodass neue Informationen im Langzeitgedächtnis verbleiben und aktiviert werden können, wenn neue, damit verbundene Daten gespeichert werden. Die Forschungsergebnisse bestätigen die Ausgangshypothese, dass beide Perspektiven ihre Vor- und Nachteile haben und zu ähnlichen Ergebnissen beim Lernprozess führen. Basierend auf der im DaF-Bereich einflussreichen Übungstypologie von Neuner et al. (1981), unternimmt diese Arbeit den Versuch, die Produktion von Lernern bei reproduktiven und produktiven Aufgaben zu verifizieren. Dabei wird untersucht, dass die Leistung der Lerner bei den reproduktiven Übungen besser ist, wenn die Grammatikalität der von ihnen gebauten Sätze aus morfosyntaktischer und pragmatisch-funktioneller Sicht evaluiert wird. Zusammengefasst zeigen die gesammelten Daten im Allgemeinen, dass keine der beiden Perspektiven beim Lehren und Lernen der Grammatik des DaF besser zu funktionieren scheint.

Schlüsselwörter: Deutsch als Fremdsprache; DaF lehren und lernen; Grammatik; Lehrwerke; Gedächtnis; Relativsätze. 


\section{LISTA DE SIGLAS}

ALE $=$ Alemão língua estrangeira

$\mathrm{DaF}=$ Deutsch als Fremdsprache (ALE)

FFLCH/USP = Faculdade de Filosofia, Letras e Ciências Humanas da Universidade de São Paulo

IE = Instituição de ensino (sinônimos utilizados: escola, instituto, academia)

IES = Instituição de ensino superior

LA = Linguística Aplicada

$\mathrm{LD}=$ Livro didático, manual

LE = Língua estrangeira

LM = Língua materna

QECR $=$ Quadro Europeu Comum de Referência para as Línguas

\section{LISTA DE TABELAS}

Tabela 1 - Artigos definidos (Bestimmte Artikel) do alemão ............................................... 50

Tabela 2 - Pronomes relativos (Relativpronomen) do alemão ............................................ 50

Tabela 3 - Principais teorias de aquisição e de aprendizagem de línguas estrangeiras .......... 73

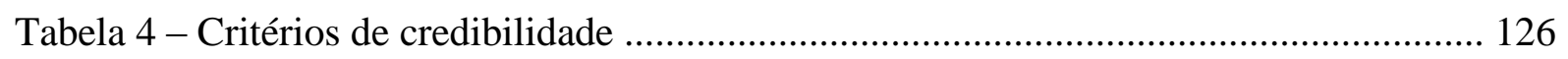

Tabela 5 - Balanço quantitativo da atividade B, Grupo A ............................................... 152

Tabela 6 - Balanço quantitativo da atividade C, Grupo A ................................................ 153

Tabela 7 - Balanço quantitativo da atividade D, Grupo A …............................................ 154

Tabela 8 - Orações relativas no nominativo, Grupo A, Atividade D .................................. 156

Tabela 9 - Erros intra e interlinguísticos na produção geral do Grupo A ............................. 159

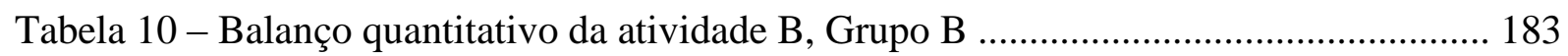

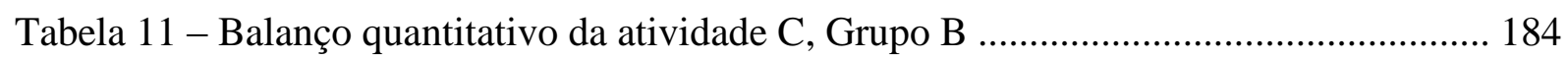

Tabela 12 - Balanço quantitativo da atividade D, Grupo B ............................................ 184

Tabela 13 - Orações relativas no nominativo, Grupo B, Atividade D .............................. 185

Tabela 14 - Erros intra e interlinguísticos na produção geral do Grupo B ........................... 185 
Eu sei muito pouco. Mas tenho a meu favor tudo o que não sei.

Clarice Lispector

Eu quero desaprender para aprender de novo.

Rubem Alves 


\section{S UMÁR I O}

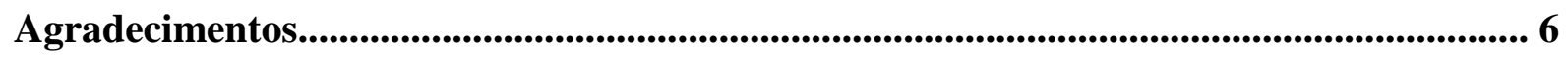

Resumo/Abstract/Zusammenfassung ....................................................................... 8

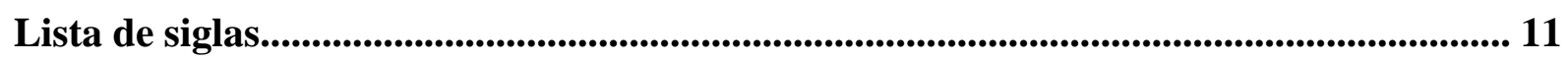

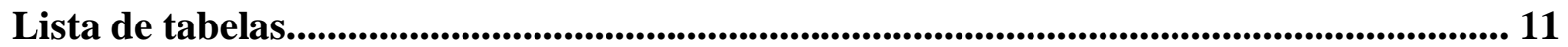

1. INTRODUÇÃ

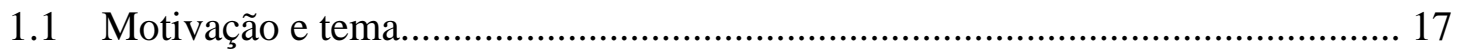

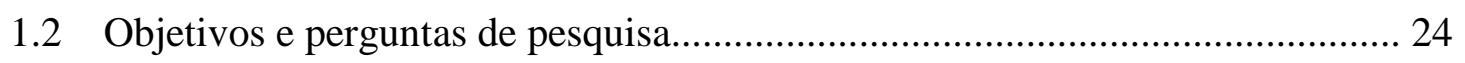

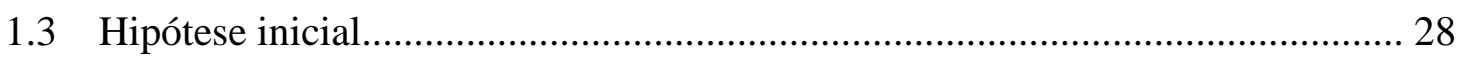

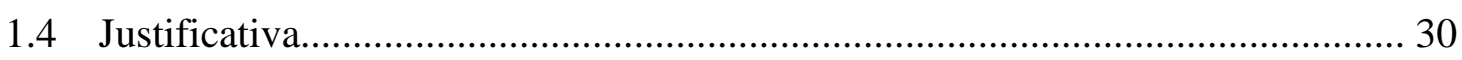

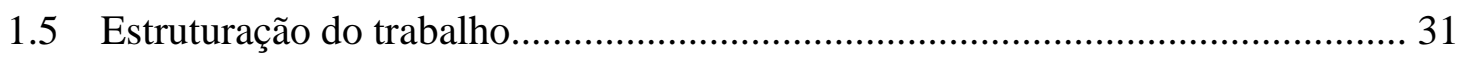

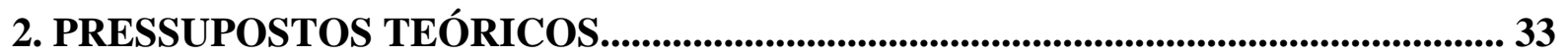

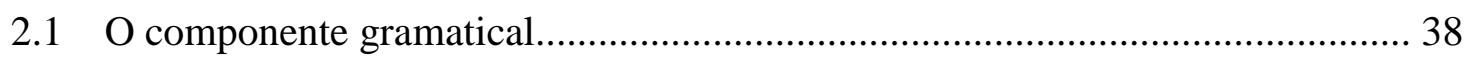

2.1.1 Conceituação (as gramáticas)........................................................ 39

2.1.2 O tópico gramatical (as Relativsätze).............................................. 46

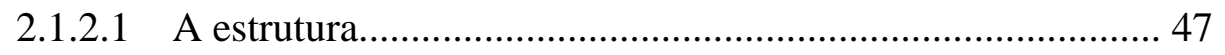

2.1.3 Gramática: entre erros, acertos, compreensibilidade e funções........... 53

2.2 Teorias de aquisição, aprendizagem e processamento..................................... 71

2.2.1 Considerações introdutórias.............................................................. 71

2.2.2 Teorias de aquisição e aprendizagem............................................. 72

2.2.3 Teorias de transição......................................................................... 78

2.2.3.1 Processamento de informação............................................. 78

2.2.3.2 Teoria da Processabilidade................................................. 85

2.3 Análise e síntese no ensino de gramática.................................................... 90

2.4 A discussão contemporânea sobre o uso do livro didático de língua estrangeira. 


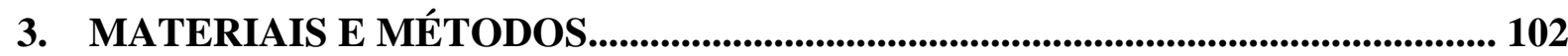

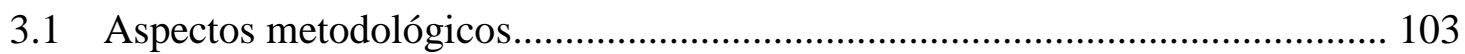

3.1.1 Paradigma, classificação e metodologia da pesquisa....................... 103

3.1.2 Contexto da pesquisa.................................................................. 105

3.1.2.1 Instituições de ensino........................................................ 105

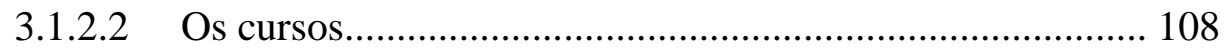

3.1.2.2.1 Participantes (alunos)......................................... 109

3.1.2.2.2 Professores-voluntários...................................... 111

3.1.2.2.3 Pesquisador..................................................... 112

3.2 Procedimentos de coleta de dados................................................................. 112

3.2.1 Os exercícios............................................................................ 114

3.2.1.1 Tipologia de exercícios...................................................... 114

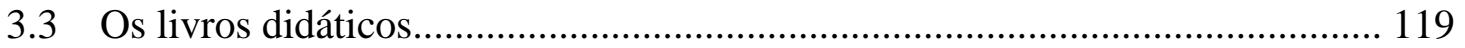

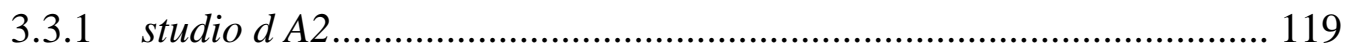

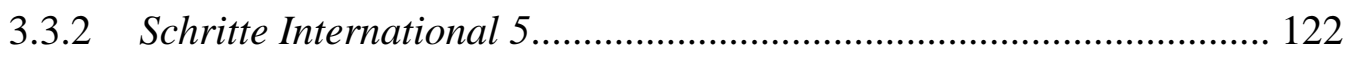

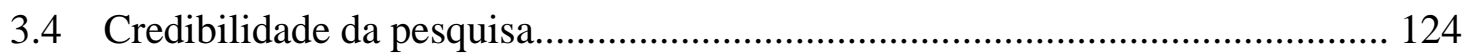

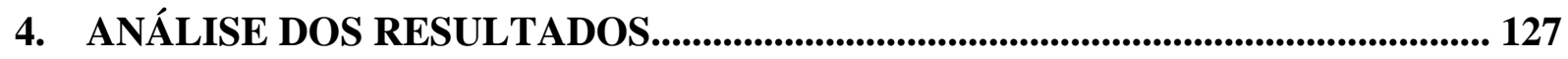

4.1 Os dados obtidos e seus desdobramentos.................................................... 130

4.1.1 $1^{\circ}$ grupo de inform. (A): Schritte International (6 informantes)....... 133

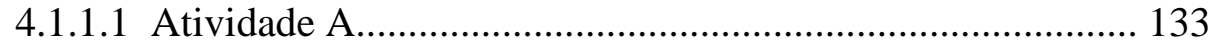

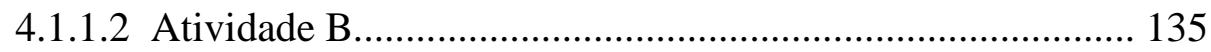

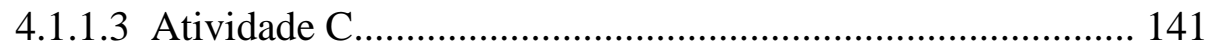

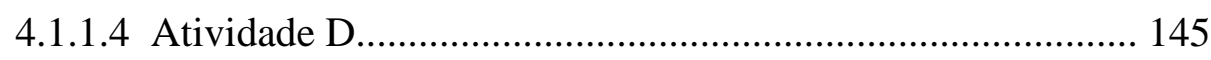

4.1.1.5 Balanço dos dados do Grupo A........................................ 152 
4.1.2 $2^{\circ}$ grupo de informantes (B): studio $d$ (6 informantes), em comparação com o Grupo A

4.1.2.1 Atividade A............................................................................ 167

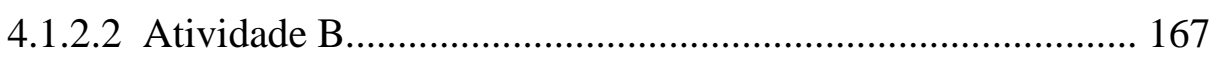

4.1.2.3 Atividade C................................................................... 173

4.1.2.4 Atividade D........................................................................ 177

4.1.2.5 Balanço dos dados do Grupo B.............................................. 183

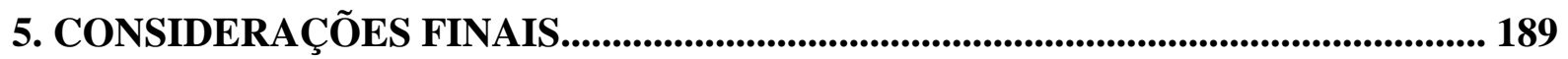

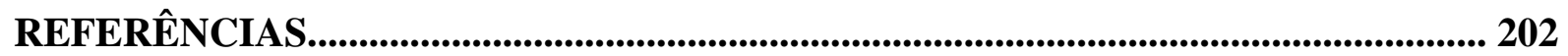

\section{REGISTROS}

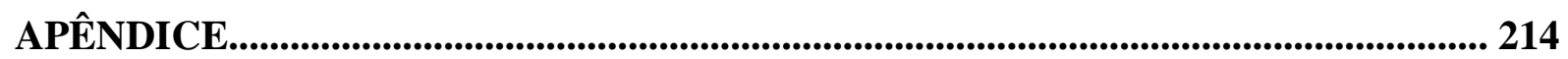

Apêndice 1a: Lista das escolas de alemão de São Paulo (cursos livres para adultos) e LDs adotados para cursos regulares dos níveis A1 a B1 do QECR............................................. 215 Apêndice 1b: Lista dos cursos livres de alemão de São Paulo para adultos oferecidos pelas universidades públicas paulistas ao público geral e LDs adotados......................................... 220

Apêndice 2a: Entrevista com o professor do grupo A...................................................... 222

Apêndice 2b: Entrevista com o professor do grupo B...……………………………..... 228

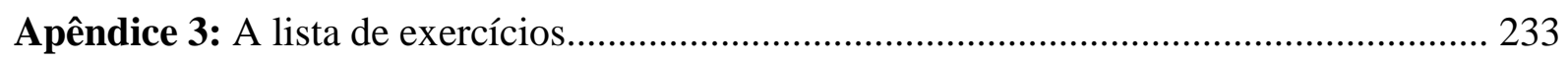

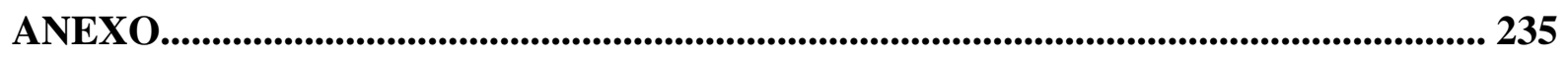

Anexo 1: Termo de consentimento livre e esclarecido....................................................... 236

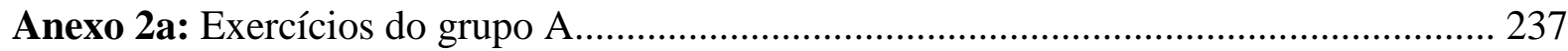

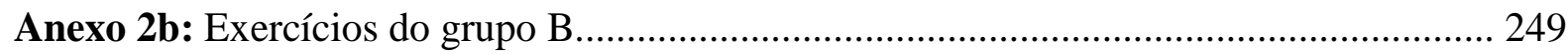

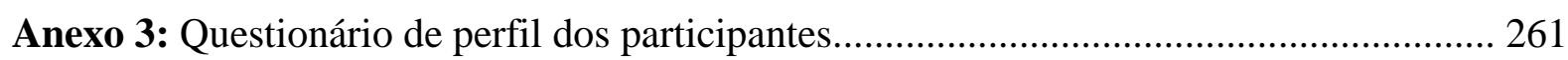

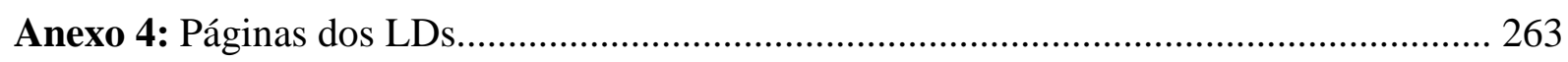


1. INTRODUÇÃO 


\subsection{Motivação e tema}

Atuando desde 1998 como professor de alemão língua estrangeira, sempre alimentei ${ }^{1}$, em paralelo, a intenção de seguir a carreira acadêmica e, nos últimos anos, comentava com colegas pesquisadores e docentes que somente ingressaria no programa de pós-graduação de nossa área quando um tema instigante emergisse do meu trabalho em sala de aula e da observação de fenômenos advindos do processo de ensino-aprendizagem. Não tardou em darse a gênese da dúvida a dirimir que me levaria à formulação da hipótese motivadora e justificativa da elaboração do projeto inicial de pesquisa, constituinte do nó górdio que impulsionou o desenvolvimento da presente dissertação. Mais tarde, percebi que este trabalho não apenas deveria partir de uma realidade observável e observada em salas de aula, mas também oferecer, de alguma forma, subsídios para o trabalho de professores, instigando a reflexão sobre aspectos de nossa prática profissional e questões concernentes à mesma sala de aula. Tendo isso em mente é que desenvolvi o presente texto. Desse modo, tudo começou a partir de meu próprio fazer docente em meio institucional e da busca de uma verificabilidade científica para os fenômenos constatados e para aqueles intuídos.

Trabalhando em uma escola ${ }^{2}$ de idiomas mediante a adoção de um material didático que me era até então desconhecido, passei por aquele processo familiar aos professores que consiste em dedicar mais tempo que o normal à preparação de aulas e à exploração dos novos livros. Em pouco tempo, ao adquirir mais familiaridade com o manual em uso nesse contexto, deparei-me com fenômenos que chamaram minha atenção e suscitaram dúvidas - que rapidamente me prontifiquei a descortinar. Nesse material, o livro didático studio $d^{3}$, causoume estranhamento o modo como ocorria a progressão dos tópicos de tipo gramatical. Em vez de explorados de uma vez, em uma totalidade temática, os temas gramaticais pareciam ser desmembrados em fragmentos apresentados ao aprendiz e ao professor ao longo das diferentes lições, o que ia de encontro ao modo como eu mesmo havia aprendido a língua. Nos anos noventa, frequentava cursos de alemão nessa mesma escola onde agora atuava

\footnotetext{
${ }^{1}$ Este trabalho será redigido na primeira pessoa do singular devido ao caráter pessoal das motivações e ações conduzidas ao longo da pesquisa. A primeira pessoa do plural será reservada para formulações em que se esteja incluindo ou convidando o leitor.

${ }^{2}$ Aqui, o termo "escola" será empregado como sinônimo de instituição de ensino, instituto de ensino de línguas estrangeiras e academia de ensino. O uso variado desses parassinônimos ao longo do texto visa a fins meramente estilísticos, sem distinções conceituais.

${ }^{3}$ Funk et al. (2010).
} 
profissionalmente, sendo adotado, naquela época, o material Themen neu, com o qual lecionei durante três anos. Mais adiante, trabalhei com uma variedade de livros didáticos ${ }^{5}$, mas em nenhum deles as coisas pareciam funcionar como em studio $d$.

Rapidamente, passei a prestar especial atenção no ritmo de aprendizagem de meus alunos mediante a utilização desse livro. A comparação, contudo, se fazia difícil, uma vez que eu não estava trabalhando, naquele então, com outro livro de ecologia diferente, e me via sem parâmetros para medir o rendimento discente com uma ou outra forma de aprender gramática. Seria necessário, por isso, estabelecer uma comparação entre os produtos de um alunado que frequentasse um curso com studio $d$ e outro que estudasse com um material de funcionamento distinto. Essa questão se resolveu em pouco tempo, uma vez que o livro didático Schritte International $^{6}$, no qual os conteúdos são apresentados do modo que antes me era familiar, era e é utilizado em um número relevante das escolas de alemão língua estrangeira ${ }^{7}$ do estado de São Paulo. Cabia, assim, comparar as produções de alunos que estivessem aprendendo com um ou outro LD para chegar, talvez, à resolução da dúvida anteriormente expressa.

Nesse meio-tempo, os primeiros ensaios de levantamento bibliográfico conduziramme à releitura de Notional Syllabuses, de Wilkins (1978). O contato com esse texto me levou a conhecer o que o autor denomina abordagem sintética (studio d) e abordagem analítica (Schritte International) de progressão gramatical em LD ou cursos de língua estrangeira. As formas de apresentação da gramática em ambos os livros, Schritte e studio d, estavam sendo teoricamente fundamentadas e estudadas há décadas, embora uma observação dos materiais de ALE atualmente disponíveis no mercado sublinhe uma tendência mais recente de adoção da abordagem sintética, enquanto a analítica faz-se mais visível nos materiais antecedentes.

\footnotetext{
${ }^{4}$ Aufderstraße et al. (1994).

${ }^{5}$ Doravante, também LD.

${ }^{6}$ Hilpert et al. (2011).

${ }^{7}$ Doravante, também LE. Estando ciente da distinção conceitual, na literatura, entre língua estrangeira (LE) e segunda língua (L2) - no caso do alemão, o par de termos DaF (Deutsch als Fremdsprache, alemão como língua estrangeira) e DaZ (Deutsch als Zweitsprache, alemão como segunda língua) -, ressalto que, neste trabalho, não farei referência ao segundo termo, uma vez que unicamente considerarei contextos em que o alemão é aprendido no Brasil, mais especificamente em São Paulo, por falantes de português brasileiro como LM sem conhecimentos prévios de alemão, e em meio institucional. Para mais quanto a essa distinção teórica, com aplicações nos diversos contextos brasileiros, ver Pupp Spinassé (2006).
} 
A pesquisa levou-me, também, a deter-me mais detalhadamente sobre as teorias psicolinguísticas e de aquisição da linguagem, e a encontrar, em seu seio, os estudos acerca do processamento informacional baseados na distinção das instâncias da memória humana (de trabalho, de curta e longa duração, entre outras denominações e conceitos ${ }^{8}$ ). Estava estabelecido, assim, o enlace entre o uso das memórias - questão que considero de absoluta ubiquidade durante processos de ensino-aprendizagem ${ }^{9}$, já que estes implicam o constante depósito e processamento de informação nas memórias - e a adoção de cada uma das abordagens: a analítica, de um lado, gerando um carregamento maior do que inicialmente se denomina memória de trabalho, por meio da transmissão de um volume mais pronunciado de informações de uma só vez, e a sintética, por outro, com depósitos periódicos de conteúdos na memória de trabalho/curta duração, com revisões esporádicas que permitiriam seu registro na de longa duração para, mais adiante, e com a de trabalho ou a de curta duração mais aliviada, haver novo acúmulo e entrelaçamento de dados.

Restava, então, elaborar uma forma eficaz e crível de realizar testes com estudantes que trabalhassem com um e com outro livro, com vistas a mensurar e comparar seu rendimento, entendido e avaliado aqui como os níveis de retenção e da consequente aplicação da matéria estudada quando da feitura de exercícios escritos. Para tal, adotou-se a tipologia de exercícios de Neuner et al. $(1981)^{10}$, uma proposta que contempla os requisitos da abordagem comunicativa e se emprega em diferentes cursos de formação de professores de ALE de amplo alcance e influência entre nossa comunidade profissional ${ }^{11}$. Em sua tipologia, o autor estabelece um continuum de tipos de exercícios (de A a D), perfazendo um percurso que conduz, partindo-se das atividades mais dirigidas e automáticas, àquelas mais produtivas, nas quais o estudante elabora textos (na mais ampla e pansemiótica acepção do termo) livremente. Decidi-me pela aplicação de exercícios que cobrissem essas diversas etapas e fossem

\footnotetext{
${ }^{8}$ Conceitos esses abordados no capítulo que lhes foi dedicado entre os fundamentos teóricos do trabalho (primeira parte). Nessa parte da dissertação, serão cotejados conceitos e termos de importantes teóricos da área a este respeito e expressarei preferência pela terminologia que me pareça mais adequada, sem ignorar a diversidade que existe nos discursos a respeito do tema.

${ }^{9}$ Almeida Filho (2005, p. 18) inclui a questão da memória entre os "fatores internos do processo de aprender e ensinar línguas".

${ }^{10}$ As circunstâncias da escolha da tipologia de exercícios de Neuner et alii, em detrimento de outras também amplamente difundidas na área de ALE, como as de Häussermann; Piepho (1996) ou Rampillon (2000), são abordadas na segunda parte deste trabalho, "Materiais e Métodos".

${ }^{11}$ Tais como a Deutschlehrerausbildung, do Goethe-Institut São Paulo, pólo continental (América do Sul) na formação de professores para a docência de ALE nos níveis A1, A2 e B1 do QECR.
} 
aplicados, nos dois contextos de ensino-aprendizagem, por professores voluntários. Essa decisão se justifica uma vez que a aplicação dos testes nos grupos que estudavam com Schritte teria de ser necessariamente conduzida por outrem, por motivos há pouco mencionados. Para manter esse padrão, de modo que toda a coleta de dados se desse de forma metodologicamente homogênea, decidi não aplicar os exercícios junto aos meus alunos de studio $d$, abrindo mão, assim, de realizar uma pesquisa-ação.

De acordo com estas considerações, pode-se afirmar que esta pesquisa consiste em um trabalho em Linguística Aplicada (LA) e, como tal, em uma investigação interdisciplinar que recorre também a elementos advindos da Linguística Teórica, da Psicolinguística e da Educação, entre outras fontes e áreas do saber. O texto se erige no âmbito da primeira das quatro grande áreas de concentração da LA, a saber, o campo do Ensino/Aprendizagem de Línguas e, mais especificamente, a área de língua estrangeira (ALMEIDA FILHO, $\left.2005^{12}\right)^{13}$.

A partir disso deve-se considerar, também, que a condução de uma pesquisa acerca de processos de ensino-aprendizagem de $\mathrm{ALE}^{14}$ no Brasil mediante o emprego de livros didáticos internacionais produzidos na Alemanha abre espaço a uma importante digressão acerca das condições em que se dá o uso desses materiais em nossos contextos institucionais. Na discussão hodierna a respeito do tema, e em alinho com questões tão correntes na LA atual, como o ecletismo e o pós-método, faz-se importante que se registre, aqui, ciência a respeito da necessidade de que o professor molde a utilização do livro didático às condições concretas do processo de ensino-aprendizagem. Entre outras dessas condições, considerem-se o contexto sócio-histórico-cultural em que se realiza o curso, realidades, necessidades e crenças dos estudantes, o estado das relações entre as culturas de origem e meta etc. Apesar disso, atua-se aqui às voltas com um recorte específico e delimitado da realidade, que são os

\footnotetext{
${ }^{12}$ As outras três grandes áreas da LA sendo, segundo o autor (ALMEIDA FILHO, 2005, p. 30), os "usos da Tradução/Interpretação", os "usos da Lexicografia/Terminologia" e as "Relações Sociais/Profissionais e Linguagem". A despeito do uso da barra que o autor faz ao lançar mão do termo "ensino/aprendizagem", aqui se opta pelo emprego do hífen, ao considerar-se o significado excludente do primeiro sinal, em contraposição ao de interligação do segundo.

${ }^{13}$ Os fundamentos teóricos do trabalho serão esboçados no capítulo 1, recortados lembrando as palavras de Severino (2000, p. 153), segundo quem "na elaboração de uma tese ou dissertação, não se deve falar de tudo, de todos os aspectos envolvidos pela problemática tratada. [...] O importante é ater-se ao substancial da pesquisa, não se perdendo em grandes retomadas históricas, em repetições, em contextualizações muito amplas. Não se pode falar de tudo ao mesmo tempo numa tese".

14 “Alemão (como) língua estrangeira".
} 
cursos que nos ofereceram os dados mais adiante analisados ${ }^{15}$. No caso desses cursos, trabalhou-se com informações que nos foram ofertadas por professores que declaram utilizar as respectivas lições dos LDs adotados pelas instituições onde exercem sua profissão. De acordo com depoimentos dos professores documentados no apêndice e retomados na segunda parte da dissertação ("Materiais e Métodos”), esses profissionais operam algumas modificações dos insumos presentes nos LDs, e eventualmente alteram a ordem de apresentação das atividades, mas devem responder, entretanto, a prescrições institucionais quanto ao uso do livro (tratadas na parte 2 da dissertação), em concordância com as quais gozam de liberdades limitadas para alterar o uso esperado do material. Em assim sendo, este trabalho opera num contraponto entre a realidade de mundo observada, a problemática construída e as discussões teóricas ou discursos atuais selecionados acerca do tema. De acordo com o recorte de tema aqui apresentado, deve-se frisar que este não pretende ser um trabalho sobre livros didáticos ou que tematize criticamente as condições de seu uso, mas sim uma pesquisa que tange esse tema, assim como abordado no presente texto.

Quanto à definição dos exercícios aplicados pelos docentes, a primeira limitação que se encontrou nesse âmbito foi a necessidade de exclusão da produção oral dos informantes, devido a uma dificuldade pronunciada em registrar os seus textos, principalmente levando-se em conta que essa tarefa seria posta em marcha por outros. A análise da produção de textos escritos, todavia, mostrou-se mais factível e adequada, segundo a taxonomia de Neuner et al. (1981), à categoria $\mathrm{D}^{16}$. Desse modo, idealizaram-se exercícios que permitiriam ao pesquisador verificar a ocorrência de diferenças qualitativas nas produções em atividades mais guiadas e mais livres. Além disso, como nos lembra Quites (1997), evita-se, mediante o emprego de atividades escritas, a timidez do aluno, por "...se vir obrigado a falar uma nova língua na presença de outros que a conhecem a fundo" (TITONE apud QUITES, 1997, p. 8). Como prossegue a autora, (op. cit.), "redigindo textos, os informantes se sentem mais à vontade e menos expostos, já que não é sua língua materna que está sendo analisada".

Elaborei esta dissertação ciente de que, ao cotejar dados coletados junto aos alunosinformantes em apenas um dia, não realizando, assim, um estudo longitudinal, o presente

\footnotetext{
${ }^{15}$ Parte terceira da dissertação.

${ }^{16}$ Exercícios que exigem maior autonomia do aprendiz e lhe concedem maior espaço para a livre expressão e utilização do sistema linguístico. A elaboração da atividade de tipo D que se propôs aos alunos-informantes deriva também da prática pedagógica dos seus professores. Maiores detalhes e descrição desse tipo de atividades na segunda parte deste trabalho, "Materiais e Métodos".
} 
trabalho assume um perfil fotográfico e não documenta, por esse motivo, todas as etapas do processo de assimilação da estrutura por parte dos aprendentes. Dito processo, cujas duração e dimensões não podem ser previstas de antemão e certamente são variáveis de aluno para aluno, inclui a ativação de um sem-número de processos mentais e instâncias da memória e, no âmbito do ensino-aprendizagem sob a forma de cursos, implica vasta gama de medidas e propostas a serem postas em prática ao longo do tempo e dos diferentes estágios de curso pelos professores, como revisões e retomadas de conteúdos anteriormente abordados. Considero que um estudo entitulado do que se poderia denominar o processo global de assimilação de uma estrutura por parte dos estudantes exigiria, eventualmente, múltiplas coletas de dados em diversas fases do andamento da aprendizagem, o que eventualmente extrapolaria o prazo oficial de conclusão do curso de mestrado acadêmico ${ }^{17}$, tratando-se, assim, de uma possibilidade de que se proceda, num estágio ulterior, à definição de um novo talhe fenomenológico ao qual poderia ser dedicada uma eventual pesquisa de doutorado. Além disso, o acompanhamento das diversas fases do processo de aprendizagem das orações relativas implicaria retomadas do tema em diferentes fases desse processo, o que descaracterizaria por completo minha intenção inicial, que é a de comparar a aprendizagem da estrutura mencionada a partir das abordagens analítica e sintética. Faz-se imperioso, por isso, poder observar o rendimento de um grupo de sujeitos ao qual seja apresentada a temática gramatical em questão de uma só vez, como proposto em Schritte International, para efeitos de futura comparação com os resultados produzidos pelo outro grupo. Por fim, é-me de valia lembrar que o recorte fenomenológico que deu origem a esta investigação parte da observação de fatos que efetivamente ocorrem na realidade dos cursos de língua estrangeira oferecidos no Brasil, com especial ênfase aos dois cursos durante os quais foram colhidos os dados que são analisados neste trabalho. Ou seja, fazem parte desses cursos a apresentação e a exploração de um conteúdo gramatical novo ou parcialmente novo aos alunos e a aplicação consecutiva de exercícios de diversos tipos para verificar o aprendizado dessa estrutura, e é devido a isso que o propósito desta investigação não é outro senão analisar o que ocorre nesse momento específico do processo de ensino-aprendizagem. Esta pesquisa, sua identidade e ipseidade se definem, portanto, também pelo contraste com aquilo que o trabalho deliberadamente não almeja ser e referendar. Trata-se das perguntas que permanecem abertas a partir da condução desta investigação e que serão abordadas no capítulo que encerra o texto, dedicado às considerações finais. Malgrado essas observações, ressalte-se que o momento do processo de ensino-aprendizagem da língua e da estrutura gramatical em questão que é abordado neste

\footnotetext{
${ }^{17}$ Dois anos e meio, no caso do Programa de Pós Graduação em Língua e Literatura Alemã da FFLCH-USP, de acordo com as normas vigentes no período durante o qual se realizou esta pesquisa.
} 
texto, meu objeto empírico, é tido como parte de um processo global muito maior, mais complexo e multifatorial, cujos limites e dimensões não se pretendem tentar, desta feita, definir ou caracterizar. É nesta direção que confluem as palavras de Bazarim (2008, p. 96), com apoio em Signorini:

Quando o foco é o processo de ensino-aprendizagem, espera-se, com isso, flagrar os momentos de um processo sempre em fluxo, “identificando tanto o que já está posto quanto o que apenas se delineia, se esboça, mas já aponta para os movimentos microbianos de que é feita toda mudança social" (Signorini, 2006). ${ }^{18}$

Optou-se, nesta pesquisa, pela análise dos dados referentes a um conteúdo específico, as Relativsätze (orações relativas) do alemão, estrutura que corresponde, grosso modo, às orações subordinadas relativas restritivas e explicativas do português, conforme as taxonomias da gramática tradicional. Esta eleição se deve sobremaneira a três fatores:

1. é o caso de uma estrutura cujo tratamento se vê especialmente distribuído em partes menores ao longo de studio $d$, de modo a consistir num exemplo notório do emprego da abordagem sintética e viabilizando, assim, a pesquisa - do mesmo modo que o oposto sucede em Schritte (leia-se a abordagem analítica do mesmo tópico);

2. trata-se de uma estrutura que apresenta alto grau de dificuldade para estudantes brasileiros, por seu perfil de Satzklammer (ao ser uma oração subordinada e, assim, com verbo situado ao fim) e pela variedade de pronomes relativos disponíveis, uma vez que variam em gênero, número e caso;

3. uma das sustentações teóricas desta pesquisa, a Teoria da Processabilidade de Pienemann (1998, 2003), situa as orações subordinadas, com colocação do verbo na última posição da frase, ao final de um continuum de aquisição de estruturas da língua alemã. $\mathrm{O}$ fato das orações subordinadas encontrarem-se ao final dessa ordem de aquisição confirma o desafio singular que seu ensino-aprendizagem representa. Considera-se, na esteira desse modelo teórico e em decorrência de seus pressupostos, comparadas às subordinadas introduzidas por conjunção, que as orações relativas, implicando a presença e a declinação de um pronome relativo no

\footnotetext{
18 A citação de Signorini é parte do discurso reproduzido de Bazarim. Trata-se de SIGNORINI, I. Gêneros catalisadores; letramento e formação do professor. São Paulo: Parábola, 2006.
} 
início da frase ${ }^{19}$, consistem no tipo mais complexo de orações subordinadas alemãs, o que explica o interesse no estudo de seus processos de aprendizagem e aquisição $^{20}$.

Cumpre sinalizar, neste momento, que o ensino-aprendizagem das orações relativas no genitivo foi excluído da presente pesquisa. Isso se deve ao fato de que, nos LDs pesquisados, a sua apresentação se dá invariavelmente em separado, várias lições após os três primeiros casos (nominativo, acusativo e dativo), o que consiste num exemplo de exploração sintética do tópico gramatical. Atendo-me à abordagem das Relativsätze nos três primeiros casos, em conformidade tanto com o que sugerem os LDs quanto com as medidas tomadas pelos professores-voluntários em sua organização de curso, encontram-se ensejos tanto para a pesquisa do processo de ensino-aprendizagem dessa estrutura pela via sintética quanto pela analítica.

\subsection{Objetivos e perguntas de pesquisa}

A feitura deste trabalho norteia-se pelas perguntas de pesquisa que motivaram a elaboração do projeto e a condução em si da investigação. Procura-se encontrar respostas às seguintes questões:

1. Há diferenças, durante a realização de exercícios escritos, entre a produção de alunos que aprenderam as orações relativas de acordo com as abordagens sintética ou analítica (WILKINS, 1978) de progressão de tópicos gramaticais? Em caso positivo, e se significativas, como se manifestam ou evidenciam essas diferenças?

2. Em diálogo com a pergunta de pesquisa anterior, e de forma a expandi-la: os LD Schritte International e studio $d$, consideradas suas singularidades no tocante à evolução da abordagem explícita dos itens gramaticais, caso utilizados como material de apoio para o tratamento em sala de aula das orações relativas, e caso sejam aceitas e incorporadas suas propostas centrais a respeito, levam a resultados

\footnotetext{
${ }^{19}$ Verificar descrição da estrutura no item 1.1.2.1 deste trabalho.

${ }^{20}$ Sobre essa distinção teórica e terminológica e minha posição a respeito, leia-se o capítulo 1 deste trabalho.
} 
de aprendizagem díspares ou semelhantes? No caso de haver diferenças no aprendizado dessas estruturas entre um e outro grupo, mediante a adoção de um desses LDs, como elas se manifestam e que perfil assumem?

3. Existem divergências de rendimento, na produção de um mesmo grupo de aprendizes e, inclusive, de um mesmo aluno, entre exercícios de feitio mais e menos controlado, ou mais e menos (re)produtivos? (cf. tipologia de NEUNER et al., 1981)?

4. A apresentação analítica das orações relativas no nominativo, acusativo e dativo, num único bloco, em Schritte International, parece ocasionar, durante a realização dos exercícios, uma sobrecarga da memória de trabalho, de acordo com os fundamentos teóricos discutidos na parte primeira desta dissertação, que transpareça a partir do que se observa em sua produção linguística escrita, contrastada com a do outro grupo (studio $d)$ ?

A partir dessas perguntas, estabeleceram-se os seguintes objetivos:

- Objetivo geral:

Este trabalho, em sua versão original, visava à identificação, por meio da análise de como as Relativsätze são abordadas nos livros didáticos de alemão LE studio $d$ e Schritte International, e mediante a aplicação de testes, do grupo de estudantes que apresentaria melhores resultados ${ }^{21}$ no processo de aprendizagem de tal estrutura. Os

\footnotetext{
${ }^{21}$ Com "melhores resultados", fazia-se referência à capacitação do aluno a construir sentenças gramaticalmente corretas e consideradas estruturalmente (embora naturalmente não se ignorem os aspectos semântico e pragmático) aceitáveis por falantes nativos dessa língua. Essa capacitação permitiria que o aluno se comunicasse com nativos de forma clara e que exigisse destes o menor esforço possível de compreensão (irrritação) e, de forma prática, que atingisse objetivos de ordem socioeconômica e social (ascensão no trabalho, possibilidade de realizar estudos em países germanófonos, etc.). Estou ciente, entretanto, de que o falante nativo não necessariamente representa um "falante ideal" que se expressa exclusivamente de acordo com as regras da norma culta do idioma (haverá referência a esse assunto no corpo do texto mais adiante). Sabe-se que o alemão, assim como qualquer outra língua natural, é composto por variantes caracterizadas por diferenças diatópicas, diacrônicas, diastráticas e diafásicas (cf. classificação de variantes linguísticas de COSERIU, 1980), sendo a norma culta não mais que uma entre inúmeras variantes que dão corpo e forma ao complexo sistema linguístico. Apesar disso, o fenômeno que foi recortado, matriz desta pesquisa, entre as vastas realidades de ensinoaprendizagem de alemão LE no Brasil, consiste no trabalho com uma estrutura gramatical específica num contexto em que se adotam e seguem livros didáticos nos quais a estrutura em questão é apresentada aos estudantes sob a ótica da gramática normativo-prescritiva. Uma vez que não se contemplaram, nos cursos
} 
testes consistem em exercícios de tipologia A, B, C e D, de acordo com a proposta de Neuner et al. (1981), indo dos mais guiados e de automatização aos mais livres, que demandam maior autonomia e permitem mais expressão da criatividade por parte do aluno. Entretanto, o desenvolvimento do trabalho, impulsionado por interlocuções privilegiadas com pesquisadores experientes da área, quer seja durante o exame de qualificação, quer seja durante sessões informais de atendimento e consultoria acadêmicos, levou-me a optar por uma modificação no tom do objetivo geral. Essas interlocuções permitiram-me verificar que tanto o gesto humano da linguagem quanto o complexo fenômeno da educação, temas e áreas que este trabalho abarca devido ao seu caráter linguístico aplicado (e, assim, intrinsecamente interdisciplinar, cf. SIGNORINI, 1998; ALMEIDA FILHO, 2005), não se curvam a uma análise que se pretenda tão objetiva e sustentada num nível de objetividade binomial (sim-ou-não) a que a linguagem e a educação não correspondem ${ }^{22}$. Por isso, preferiu-se proceder a uma análise dos dois processos de ensino-aprendizagem de gramática, sustentados nos dois tipos de progressão investigados, com vistas a apontar seus pontos de interface e de divergência, qualitativa e quantitativamente, não se desconsiderando jamais o perfil essencialmente interpretativo desta pesquisa, e não mais entrando em termos de "melhor" ou "pior", que não descreveriam completa e criticamente a complexidade dos fenômenos linguísticos e educativos.

- Objetivos específicos:

1. Determinar se existe uma diferença qualitativa (e quiçá quantitativa) entre a produção escrita de alunos que tenham aprendido as orações relativas a partir das abordagens de progressão gramatical dos dois LDs empregados pelos professoresvoluntários em curso;

2. Identificar diferenças significativas de rendimento, caso as haja, dentro do mesmo grupo e a partir da análise da produção de cada aluno informante, nas atividades

durante os quais se aplicaram os testes que constituem o corpus de nossa investigação, outros usos e formas das orações relativas que não aqueles estandardizados pela normatividade e apresentados pelos LDs aqui empregados, abstenho-me de abordar esse tema nesta dissertação.

${ }^{22}$ Agradeço à Profa. Dra. Eliane Gouvêa Lousada (DLM/FFLCH/USP) por essa observação. 
dos quatro tipos propostas [cf. tipologia de NEUNER et. al. (1981), descrita na parte segunda deste trabalho];

3. Comparar as amostras de produção linguística escrita dos dois grupos de informantes e dos diferentes alunos dentro de cada grupo, descrever as semelhanças e diferenças entre elas e, a partir disso, chegar a conclusões analíticas fundamentadas no referencial teórico da dissertação;

4. Relacionar, como proposto na hipótese, as distintas abordagens de progressão gramatical em cursos de LE à ativação das duas principais instâncias da memória ${ }^{23}$, à luz das diferenças e semelhanças observadas na produção linguística escrita coletada junto aos informantes;

5. Formular novas hipóteses motivadas pela análise dos dados.

- Objetivo complementar:

Deseja-se, ainda, oferecer subsídios à comunidade de professores de ALE e pesquisadores dos campos de Linguística Aplicada, Metodologia e Didática de LE com foco em análise de livros didáticos para a avaliação e seleção desses materiais e, eventualmente, para a elaboração de atividades com vistas ao ensino progressivo de gramática a partir de uma ou outra abordagem, ou de uma coadunação de ambas. Este trabalho se erige, assim, dado o recorte de pesquisa e suas implicações específicas, entre a pesquisa e a prática de ensino de ALE. Procura-se encurtar, ao menos no âmbito de alcance temático deste texto, as distâncias frequentemente observáveis entre dois extremos que existem em nossa área: de um lado, trabalhos acadêmicos que a comunidade de professores considera inaplicáveis em sala de aula e que muito pouco parecem dialogar com a prática docente e, de outro, o fazer pedagógico pouco ou nada lastreado na produção científica de conhecimento disponível sobre os processos de ensino-aprendizagem de LE. Este trabalho se pretende, assim, passível de leitura também por parte de professores. Apesar do recorte de tema de perfil microscópico, este trabalho se pretende de aplicação generalista, com seus resultados e propostas

\footnotetext{
${ }^{23}$ Verificar terceiro capítulo da fundamentação teórica (parte primeira) deste trabalho.
} 
sendo estendíveis a outras situações e contextos (ensino em geral de gramática, envolvendo outros tópicos gramaticais, avaliação da gramática em livros didáticos, etc.). A escolha do tema, por partir de questões e problemáticas de ordem prática observadas em salas de aula contemporâneas de ALE, tem como objetivo trazer respostas a questões relativas à própria prática de ensino-aprendizagem, modo de proceder nas pesquisas de LA sugerido por Cavalcanti (2009).

Dada a definição dos objetivos acima elencados, e de acordo com a totalidade das asserções feitas até o presente momento, considero importante ressaltar, neste ponto, que não faz parte dos objetivos que guiam a elaboração desta pesquisa propor tranformações de práticas docentes ou modificações de quaisquer tipo nos LDs empregados nos cursos em que se realizou a coleta de dados. Esses manuais tampouco serão analisados criticamente, sendo apenas descritas as lições envolvidas nesta investigação no item 2.3. Ou seja, não se trata de uma pesquisa de intervenção, e sim de uma pesquisa diagnóstico. Propor reflexões e transformações de fazeres docentes e exercitar a criticidade ao contemplar materiais didáticos são ações que certamente se aplicam a importantes pesquisas acadêmicas e constituem interesses legítimos de investigação que podem gerar valiosos resultados junto aos sujeitos de pesquisa e ao contexto do ensino-aprendizagem de (A)LE. Não obstante, são propostas que não correspondem ao escopo do presente trabalho.

\subsection{Hipótese inicial}

A hipótese inicial de trabalho viu-se modificada desde o começo da pesquisa, e muito antes do início da aplicação dos exercícios. Se, num primeiro momento e conformando minha intuição inicial, a abordagem sintética parecia "logicamente" a mais adequada para que se conduzisse uma experiência pedagógica a um ritmo mais amigável para o aluno, logo as primeiras observações informais de sua aplicação em sala de aula pareciam denunciar problemas de rendimento, verificados durante a correção de exercícios gramaticais escritos que apresentavam grande número de erros estruturais associados à construção das orações relativas. A análise dos dados, por sua vez, serviu como base para a reformulação da hipótese de trabalho. 
Entende-se que a abordagem sintética, ao permitir o depósito paulatino de informações na memória, a serem reativadas por meio de revisões e ampliadas através do oferecimento de novos insumos ao alunado, pode gerar esquecimento, entre uma e outra retomada do tema, e perda de enlace entre as parcelas de conteúdo. A abordagem analítica, por sua vez, pode levar a uma sobrecarga da memória de trabalho e trazer excesso de informação para os alunos. Entretanto, não deixa tanto espaço para o esquecimento e apresenta o conteúdo completo, de modo que o estudante possa expressar o que deseja, sem limitações [como no caso sintético em que o estudante poderá expressar, no primeiro contato com a estrutura, ideias tais como „der Mann, der hier wohnt“ (pronome relativo no nominativo), mas não „der Mann, den ich sehe $^{، 24}$ (acusativo)].

A partir destas reflexões, parte-se da seguinte hipótese de trabalho: as abordagens sintética e analítica de progressão gramatical em LD, ao possuírem seus bônus e ônus, não levarão a resultados significativamente dessemelhantes no tocante a uma análise quantitativa e qualitativo-interpretativista de produção textual de alunos que estudem alemão LE a partir de cada uma delas.

Pelo fato de as análises serem levadas a cabo a partir de registros obtidos junto a grupos de estudantes que frequentam um mesmo curso em meio institucional, há-se de hipotetizar, e o faço após longas e detidas conversas com colegas professores de ALE e a partir das minhas observações e intuições, que, apesar da diferença entre indivíduos, os grupos apresentam um perfil geral reconhecível, uma identidade que emerge a partir da ação mediadora docente e um nível de produção sintonizado, devido ao contexto interativo em que se dão seus processos de construção de conhecimento e às formas sociais adotadas pelos professores, com os alunos dispostos, no grupo de studio $d$, em mini-grupos de quatro participantes (Café-Tische ou "mesinhas de café") e em semi-círculo/plenário no de Schritte.

A análise dos dados, levada a cabo na parte terceira deste trabalho, servirá como espaço para a discussão de outras hipóteses deles advindas, abdutivamente, partindo-se do fenômeno observado para a busca da mais provável explicação para ele ${ }^{25}$.

\footnotetext{
24 "O homem que mora aqui” e "o homem que eu vejo".

${ }^{25}$ Abdução segundo Peirce (2010), sintetizada por Santaella (2001, p. 119-120) como "o mais original dos tipos de raciocínio ou argumento, ela se refere ao ato criativo de se levantar uma hipótese explicativa para um ato surpreendente".
} 


\subsection{Justificativa}

O interesse do tema se deve aos seguintes fatores:

1. Como se observará em várias passagens desta dissertação, o ensino-aprendizagem de gramática consiste em uma questão que intriga profissionais e estudiosos de nossa área e foi pauta de discussões ao longo da história dos métodos e abordagens de ensino de $\mathrm{LE}^{26}$, sendo, assim, de alta relevância para a pesquisa em Linguística Aplicada;

2. Em virtualmente todas as escolas de idiomas, colégios e universidades onde são oferecidos cursos de alemão no estado de São Paulo, adotam-se livros didáticos ${ }^{27}$. Por isso, como importantes instrumentos que são, não rara vez chegando a consistir num eixo condutor do planejamento de aulas, as pesquisas que os englobem podem trazer benefícios claros na resolução de interrogantes sobre seu emprego e funcionamento;

3. Esta pesquisa e seus resultados podem fornecer critérios para a análise, o estudo ou a adoção de livros didáticos por parte dos professores e das escolas de idiomas;

4. Esta investigação, considerando-se também suas limitações, suscitará o levantamento de outras questões relacionadas e ainda não arguidas que poderão ser do interesse de colegas pesquisadores, dando-se continuidade à produção de ciência em Linguística Aplicada ao ensino-aprendizagem de (A)LE.

5. Neste trabalho alinhavam-se múltiplas perspectivas teóricas, uma vez que aqui se abarcam questões relativas ao ensino de gramática, mais especificamente das orações relativas alemãs por parte de aprendizes brasileiros, psicolinguística, erros, emprego de material didático etc. Essa diversidade, que se constatou ser única após uma verificação do estado da arte acerca desses temas, jamais antes combinados dessa forma em trabalhos acadêmicos (teses e dissertações)

\footnotetext{
${ }^{26}$ Ver minha abordagem do tema em Ming (2012).

${ }^{27}$ Veja-se apêndice 1a.
} 
defendidos no Brasil, me permite afirmar que a contribuição que aqui se faz, embora modesta, é original e traz algo novo ao conjunto de trabalhos realizados neste país acerca de ALE para aprendizes brasileiros ${ }^{28}$.

\subsection{Estruturação do trabalho}

Este trabalho compõe-se de três seções-tronco. A primeira delas, subdividida em três capítulos, foi dedicada aos antecedentes teóricos que fornecem o embasamento necessário para a realização da pesquisa e dialogam com os dados obtidos e interpretados e com as considerações finais. Suas partes correspondem a quatro tópicos principais:

1. Uma revisão de teorias acerca da definição de gramática e da temática da gramática pedagógica ou da didatização de conteúdos metalinguísticos de índole gramatical, embasando a análise de livros didáticos a ser levada a cabo mais adiante no capítulo 2 - "Materiais e Métodos". Aqui será abordada, ainda, a questão dos conceitos de erro e acerto gramaticais;

2. Uma revisão das principais teorias de processamento da informação amplamente empregadas no âmbito da Psicolinguística, bem como referências a importantes teorias de aquisição e de aprendizagem;

\footnotetext{
${ }^{28}$ Para o levantamento do estado da arte, visando a verificar se este projeto consistia numa contribuição original aos estudos e discursos desta área, pretendia-se utilizar o banco de teses da CAPES. Essa base de dados, porém, encontra-se em fase de reformulação e, em maio de 2014, apenas incluía dados referentes a teses e dissertações defendidas a partir de 2011. Por esse motivo, optou-se por fazer buscas nas bases de dados das universidades brasileiras que possuem graduação em alemão e pós-graduação em Letras (ou Estudos Linguísticos, ou Linguística Aplicada etc.), mais a Unicamp e a PUC-SP, devido à tradição dessas duas instituições em Linguística Aplicada. Investigaram-se, além dessas duas, as bases de dados da USP, UNESP, UFRJ, UFPR, UFSC, UFRGS, UFPA, UFC, UFBA, UFMG, UFF, UERJ, UFMA, além de UNIOESTE e UNISINOS, de modo a verificar os trabalhos defendidos nas instituições mencionadas pelo Instituto Goethe em < http://www.goethe.de/ins/br/lp/lrn/wdl/wls/uni/ptindex.htm> (último acesso em: 01-05-2014). Não se encontrou nenhum trabalho dedicado especificamente às orações relativas do alemão sob nenhuma perspectiva de análise, de modo que, assim, já se possa atestar que este trabalho (re/a)presenta uma contribuição original. Além disso, embora Wilkins (1978) conste como referência em diversos trabalhos sobre ensino-aprendizagem de gramática de LE, não se localizou nenhum em que se tematizassem especificamente as abordagens analítica e sintética de progressão gramatical mediante o uso comparativo de LDs.
} 
3. Uma resenha da primeira parte de Notional Syllabuses (WILKINS, 1978) com a apresentação dos conceitos de abordagem sintética e analítica de progressão de itens gramaticais em cursos e LD;

4. A discussão contemporânea acerca do emprego do livro didático de LE.

A parte subsequente da dissertação corresponde ao segundo capítulo e suas subdivisões e aborda os aspectos metodológicos da pesquisa. Nela, discorre-se sobre as instituições onde se realizaram os testes e os perfis dos estudantes e professores-voluntários, bem como do pesquisador. Serão tratados, também, detalhes a respeito da aplicação dos testes, tais como tempo, etapas, procedimentos, seleção e análise de dados. Realiza-se, ainda, uma discussão sobre paradigmas e métodos de pesquisa empregados, e sobre questões relativas à credibilidade desta investigação e de seus resultados. Nesse capítulo, serão apresentadas a tipologia de exercícios de Neuner et al. (1981) e os materiais da pesquisa. Nessa parte do trabalho, trata-se também dos livros didáticos empregados e apresentam-se as partes dos capítulos desses manuais utilizadas pelos professores-voluntários nas aulas que deram origem aos exercícios constituintes do corpus.

$\mathrm{Na}$ última parte do trabalho, serão analisadas e contrastadas as informações previamente coletadas. $\mathrm{Na}$ sequência virão as considerações finais e serão arroladas as referências bibliográficas da dissertação. Seguem-se o apêndice e os anexos, onde se encontram o modelo do termo de compromisso assinado pelos participantes da pesquisa e os registros originais, i.e., cópias digitalizadas dos exercícios preenchidos pelos alunosinformantes. 
2. PRESSUPOSTOS TEÓRICOS 
Segundo Santos Filho \& Gamboa (1995, p. 88), as teorias podem ser consideradas "maneiras diversas de tentar articular diversos aspectos de um processo global e de explicitar uma visão de conjunto." Nesse sentido, não existe uma relação representacional, especular e mimética entre teoria e realidade, ou seja, a teoria não é "uma representação, uma imagem, um reflexo, um signo de uma realidade que cronologicamente, ontologicamente, a precede." (SILVA, 2007, p. 11). Ao contrário, uma determinada teoria constrói o seu objeto entre vários possíveis criando também, conseqüentemente, uma e não a realidade. Assim, faria mais sentido, conforme Silva (2007, p. 11), falar em discursos ou textos e não em teorias, pois um discurso "produz seu próprio objeto: a existência do objeto é inseparável da trama lingüística que supostamente o descreve." (Silva, 2007, p. 12), principalmente porque "é impossível separar a descrição simbólica, lingüística da realidade - isto é, a teoria de seus 'efeitos de realidade'. (Silva, 2007, p. 11). Nessa perspectiva, um discurso sobre o processo de ensino-aprendizagem de línguas não representaria mimeticamente esse processo, mas sim, construiria uma noção particular desse processo ou de algum de seus elementos. Com isso, aquilo que os objetos de pesquisas são depende da forma como eles são construídos pelos diferentes discursos, ou seja, pelas diferentes teorias. A maneira de construir o objeto de pesquisa, portanto, não é neutra, pois a forma como o pesquisador olha a realidade é influenciada por esses discursos (e também por suas crenças e valores). (BAZARIM, 2008, p. 94 - sublinhados da autora $)^{29}[$ sic $]$

Para a realização deste trabalho, houve a necessidade de proceder a uma diversidade de recortes, desde a delimitação pretensamente precisa do objeto de estudos (fenômeno simultaneamente escolhido junto à realidade social e (re)construído discursivamente) até a escolha da fundamentação teórica que não apenas atuaria na própria construção do objeto de estudos, mas também sustentaria a análise dos dados empreendida dentro desse construto, sendo ela mesma um construto, e que foi sendo adaptada e acomodada à luz da emersão desses dados durante a condução da pesquisa. Perante essa necessidade de recortar, depareime com duas pluralidades: uma é mais específica e se refere à grande quantidade heteróclita de insumos teóricos (discursos) que perfazem os estudos dentro da própria LA, decorrente do caráter inter, multi e transdisciplinar dessa ciência e dos trabalhos realizados em seu seio. A outra, mais geral, refere-se à vastidão das possibilidades de embasamento teórico de quaisquer estudos que tenham como objeto linguagens e/ou educação. Por isso, optou-se por vasculhar antecedentes teóricos pertinentes, de forma geral, aos arcabouços próprios da LA ao ALE, com foco nas teorias de aquisição e de aprendizagem e em concepções de língua, gramática e erro encontradas em teorias aninhadas nessa disciplina ${ }^{30}$, em detrimento de outras, muito válidas, que circulam entre os discursos da Linguística Teórica, mas que levariam o trabalho para outros rumos, menos próximos da sala de aula e dos fatos aos quais se pretende lançar

\footnotetext{
${ }^{29}$ A autora cita SANTOS FILHO, Gamboa. Pesquisa educacional; quantidade - qualidade. São Paulo: Cortez, 1995 e SILVA, T. T. Documentos de identidade; uma introdução às teorias do currículo. 2.ed. Belo Horizonte: Autêntica, 2007.

${ }^{30}$ Tendo em vista que encaro os registros coletados como produtos que são parte de um processo.
} 
luz e dos quais pretendo aproximar-me, (re)construindo-os à minha maneira, que é reflexo, simultaneamente, de minhas crenças, concepções, experiências e atual nível de maturidade. De modo mais específico, este trabalho se insere na área que costumeiramente se denomina, entre os germanistas, DaF (Deutsch als Fremdsprache/Estudos do alemão como língua estrangeira), e privilegia insumos teóricos nela circulantes e influentes. Conforme Uphoff (2013, p. 220), "trata-se de uma área que apresenta uma longa tradição prática de ensino do idioma e que alcançou, nas últimas décadas, também o status de disciplina acadêmica, além de uma posição destacada nas pesquisas sobre o ensino-aprendizagem de idiomas no âmbito internacional."

Considero importante, antes de apresentar os fundamentos do trabalho, assumir um posicionamento em relação a duas discussões presentes no seio das teorias de LA ao ensino de línguas: a questão do foco no produto $v s$. no processo e a distinção teórica entre aquisição e aprendizagem. Quanto à primeira discussão, Fontana e Lima (2009, p. 16-17) assim a resumem:

\begin{abstract}
Inicialmente, a ênfase das pesquisas [em LA ao ensino de línguas] concentrou-se no produto resultante do processo de aquisição, estabelecendo o foco dos estudos empíricos na descrição da interlíngua (a língua do aprendiz), definida como um sistema estruturado e construído pelo aprendiz em qualquer etapa do desenvolvimento da segunda língua (Selinker, 1972; Gass, Selinker, 2008). Posteriormente, verifica-se uma mudança: os estudos da linguagem, na perspectiva teórica da Aquisição de Segunda Língua (ASL) em situação instrucional, têm estabelecido o foco nos processos, nos fatores implicados e nos sujeitos que estão adquirindo uma outra língua que não a sua língua materna. Nessa perspectiva, os principais estudos têm enfocado a interação, pois consideram a experiência de conversar o aspecto mais relevante para a aquisição da língua, uma vez que oferece oportunidade simultânea para a obtenção do insumo e do feedback necessários para o aprendiz construir sua gramática, modificando e ajustando a sua produção em direção à evolução da língua que está aprendendo. ${ }^{31}$
\end{abstract}

Considerando-se essas asserções e a natureza da presente pesquisa, pode-se afirmar que aqui se foca, primeiramente, no produto da aprendizagem dos participantes, ao analisarem-se e interpretarem-se registros de sua produção linguística (interlíngua) coletados num momento específico do seu processo maior de ensino-aprendizagem. Deste modo, considero os produtos como insumos que fotografam momentos decisivos de dito processo, sem desconsiderar, com isso, o fato de que se inserem num âmbito maior do ensinoaprendizagem, i.e., de que os produtos são extraídos do processo, de forma que, numa

\footnotetext{
${ }^{31}$ Os textos citados pelas autoras constam das referências ao final do trabalho, uma vez que também foram consultados por mim.
} 
investigação que lança luz mais diretamente sobre os primeiros, não se esteja desconsiderando o segundo. Assim, teorias que focam o processo podem e devem ser mobilizadas, com vistas à complementaridade, em estudos que analisam produtos, já que o processo não se interrompe quando se enfatizam os produtos, e esses produtos nos informam acerca de fases passadas do processo, possibilitando também a formulação de hipóteses sobre seus aspectos vindouros. No recorte deste trabalho, especificamente, não houve espaço para análises da interação entre os aprendentes, mas o foco nesta última faz-se presente em outros momentos dos cursos frequentados pelos alunos nas duas escolas.

No tocante à distinção aquisição/aprendizagem, célebre em nossa área de estudos, que automaticamente nos remete a Krashen $(1981)^{32}$, e também defendida por McLAUGHLIN (1978a, cf. FIGUEIREDO, 1995), existem autores, como os supracitados, que frisam as diferenças entre ambos os processos, enquanto outros, como Ellis (1987) e Gass (1989), não os diferem (FIGUEIREDO, 1995). De forma geral, os pesquisadores que sublinham as dessemelhanças entre a aquisição e a aprendizagem associam a elas fatores como, respectivamente, a informalidade $v s$. a formalidade, o caráter inconsciente $v s$. o caráter consciente, automático vs. controlado de ambos os processos, ou ainda o saber $a$ língua vs. o saber sobre a língua ${ }^{33}$. Entretanto, embora existam distinções cristalizadas entre os dois conceitos, pode-se considerar que um processo inicialmente rotulado como de aquisição eventualmente incorpore características de aprendizagem, e vice-versa, fragilizando o caráter supostamente estanque e monolítico dessa divisão terminológico-conceitual. Os processos são, portanto, complementares, e uma divisão radical entre ambos, que os considere totalmente distintos, não nos pode servir mais que didaticamente. Assim, num contexto característico da aprendizagem, como os cursos de LE fora dos territórios em que essa línguaalvo é falada como materna, procura-se muitas vezes emular as características da aquisição mediante simulações de interações "naturais" ou autênticas em sala de aula. Como afirma Richter (2000, p. 36 apud SOBROZA, 2008, p. 4),

quando se quer autenticidade de experiência, a ambientação externa à sala de aula é indispensável. Quando isto não for possível - o caso mais freqüente de situações de não imersão -, simulações na sala de aula ajudam sobremaneira, na medida em que propiciam autenticidade do modelo de situação: em vez de agir com o fato acontecendo, age-se de maneira semelhante à prevista (consensualmente) para esse tipo de acontecimento, toda vez que ocorrer. [sic]

\footnotetext{
${ }^{32}$ Veja-se tabela 3 no item 1.2.2.

${ }^{33}$ Krashen também comparava a aquisição de LE por parte de adultos ao modo como as crianças se apropriam "naturalmente" da LM.
} 
Também se pode citar, de um lado, a assimilação inconsciente de chunks em contextos de aprendizagem formal como uma ocorrência que se aproxima das características próprias da aquisição (STANICH, 2008) e, de outro, a aprendizagem de certas questões (meta)linguísticas durante o uso espontâneo da língua não-materna, num território em que ela é falada e durante a interação com nativos, como flashes de aprendizagem inseridos em contextos típicos de aquisição ${ }^{34}$. Por esses motivos, este trabalho inclui menções a teorias de aprendizagem e de aquisição, consideradas complementares enquanto faces de um mesmo grande e complexo processo. $^{35}$

\footnotetext{
${ }^{34}$ Trata-se de momentos tão típicos como aqueles em que o estrangeiro, durante a conversa na LE com o nativo, lhe faz perguntas sobre o vocabulário, a gramática, a fonética ou as formas de uso (questões pragmáticas) da língua.

${ }^{35}$ Ver tabela 3 para uma retomada e aprofundamento dessa questão.
} 


\subsection{O componente gramatical}

Neste capítulo, tenciona-se explorar as definições de gramática pertinentes à nossa área de estudos para, deste modo, chegar ao conceito de "gramática pedagógica" ou, de forma parafrástica, à pedagogização de conteúdos linguísticos de tipo gramatical, foco de interesse central deste trabalho. Colocar em discussão os diferentes conceitos de gramática nos levará ao encontro daquele(s) que nos auxiliarão a definir os parâmetros de julgamento da gramaticalidade $^{36}$ dos enunciados formulados pelos informantes da pesquisa, como se observará na terceira parte desta dissertação.

As muitas tentativas de definição, por parte de diversos autores, do que venha a significar "gramática" são frequentemente destoantes, ainda que uníssonas ao sublinhar a dificuldade que lhes é inerente e a polissememia do vocábulo em questão. Não há uma só gramática, senão muitas, em uso na linguagem corrente e no jargão (meta)linguístico. A disparidade das tentativas de definição do que quer que signifique "gramática" depende, sobretudo, do ângulo a partir do qual o analista se debruce sobre o tema. Entre os muitos significados atribuídos ao vocábulo, nos seios de diferentes correntes teóricas e de pensamento, evidencia-se um ponto de intersecção: de modo constante, corresponderiam aprioristicamente à gramática ou "às gramáticas" noções tais como ordem, normas, conjunto de regras, sistema.

Aqui, pretende-se expor um panorama de algumas das principais definições de gramática ensaiadas por estudiosos do gênero, de modo a realçar manifestamente as que mais se aplicam aos propósitos deste trabalho. Estabelece-se, a seguir, um diálogo entre elas que culmina numa proposta quadripartite de um continuиm de significados interdependentes para o termo. O fio condutor e eixo base desse diálogo será o modelo do linguista Gerhard Helbig (1993), com frequência citado em textos de ampla aplicação em cursos contemporâneos de formação de professores de alemão como língua estrangeira e segunda língua, a exemplo de Funk \& König (1991) e Spannhake \& Bogacz-Groß (2008). Helbig distingue três acepções principais para o termo em questão, das quais me ocuparei por etapas.

\footnotetext{
${ }^{36} \mathrm{O}$ conceito de erro será abordado no item 1.1.3.
} 


\title{
2.1.1 Conceituação (as gramáticas)
}

\author{
À primeira (acepção A) corresponderia
}

das der Sprache innewohnende Regelsystem, unabhängig von dessen Beschreibung durch die Linguisten und von dessen Beherrschung durch die Sprecher ${ }^{37}$ (1993, p. 21).

Ao encontro do anteriormente exposto, é preciso sublinhar o fato de que um sistema de regras intrínseco à língua será concebível tão somente enquanto fenômeno de realização mental e índole psíquico-afetiva, lógica e social (COSERIU, 1986), tal qual a própria língua. Saussure (1970 [1916]) salientava em seu Cours que o signo linguístico se compõe de um sentido indissociável de uma imagem acústica, sendo ambos de ordem notoriamente psíquica. A língua (langue), construto social, convencional, estaria depositada nos cérebros de seus falantes, que a utilizariam para expressar-se mediante os atos de fala (parole), sem, contudo, disporem da possibilidade de modificá-la individualmente. Não obstante, o caráter vivo e mutável da língua deixa-se entrever a partir da comunicação entre seus falantes nela assentada. Pelo seu domínio natural desses mecanismos, os nativos de uma língua ${ }^{38}$ podem-se considerar todos gramáticos em primeira instância. Assim como os signos, as normas determinantes de suas combinações geradoras de sentido estão depositadas nos cérebros de todos os falantes de uma língua, e cada um deles se encontra em condições de identificar instantaneamente infrações a essas regras que comprometam a expressão de sentido ${ }^{39}$. Helbig cita, como exemplos de frases malformadas em alemão, "Er treffte jeden Tag seinen Freund" (incorreta no âmbito morfológico), "Er besucht jeden Tag" (sintaticamente inaceitável) e "Peter stirbt manchmal" 40 (inviável do ponto de vista semântico) ${ }^{41}$. Nos três casos, um falante nativo dessa língua reconheceria sem maiores dificuldades os desarranjos sistêmicos

\footnotetext{
37 “O sistema de regras inerente à língua, independente de sua descrição por parte de linguistas e de seu domínio pelos seus falantes”. (São minhas todas as traduções em notas de rodapé ao longo do trabalho).

${ }^{38}$ Não se pretende dizer com isso que os nativos e suas intuições serão tomados, neste trabalho, como base para a determinação indubitável da (a)gramaticalidade de enunciados. Essa questão será matizada dentro de alguns parágrafos.

39 Aqui se refere às regras gerais de funcionamento da língua, em suas diversas variantes e em contextos comunicativos concretos, e não necessariamente à obediência à norma culta.

${ }^{40}$ Algo como "Ele encontria diariamente seu amigo", "ele visita diariamente"e "Peter morre às vezes".

41 Jovanovic (1986, p. 152) nos lembra dos níveis fonológico, morfossintático e semântico na produção de enunciados, e afirma: "Queremos deixar claro que não concordamos com a separação dos níveis sintático e semântico, por entender que são interrelacionados e interdependentes. Esta divisão [...] tem finalidade analítica".
} 
pronunciados nessas sentenças, o que vai em direção à identificação, por parte de Chomsky (2002 [1957]), de sentenças gramaticais (em oposições às agramaticais) como sendo aquelas aceitáveis por um falante nativo, dotado de um conhecimento implícito sobre o que constitui a língua materna e como ela funciona (competência $)^{42}$.

A acima transcrita acepção A atribuída por Helbig ao termo "gramática" implica, ainda que ao excluí-la, a possibilidade do exercício metalinguístico. O sistema de regras ordenador da linguagem verbal não depende de sua descrição por parte dos linguistas, mas essa atividade existe, no Ocidente, desde a Antiguidade (e, no mundo, desde Pāṇini, na Índia do séc. V a.C.) ${ }^{43}$ e, desde então, resulta em diferentes modelos teóricos dedicados à descrição de tal sistema. Cada um desses modelos também se denomina gramática. Tem-se, assim, a Gramática Tradicional, a Gramática de Valências, a Gramática Gerativa, entre diversas outras. À gramática compreendida como atividade metalinguística se dedica a segunda acepção de Helbig (B), que se refere a "die Abbildung des der Sprache innewohnenden Regelsystems durch die Linguistik ${ }^{44, "}$.

A delimitação de um terceiro semema para "gramática", por parte do linguista alemão (acepção C), suscita dúvidas quanto à univocidade de sua primeira acepção. Verifique-se: "Grammatik C: das dem Sprecher interiorisierte Regelsystem (seine "subjektive Grammatik”), auf Grund dessen dieser die betreffende Sprache beherrscht"45 (1993, p. 21).

A dualidade gramática interna/gramática externa, proposta por alguns autores, dá lugar, em Helbig, a uma tríade conceitual, onde tanto a noção A quanto a C se ocupam da língua como fenômeno necessariamente mental. Entretanto, uma tentativa de apartar a gramática enquanto sistema de regras de seus falantes, o que passaria a supor a acepção helbiguiana $\mathrm{A}$, em oposição ao recém-apresentado significado $\mathrm{C}$, não nos pode ser de serventia senão em contextos puramente teóricos.

\footnotetext{
${ }^{43}$ Um histórico conciso e contundente dos estudos e notações gramaticais na Índia e na Europa se encontra em Raster (2010).

44 “A representação do sistema de regras inerente à língua por parte da linguística”.

45 “Gramática C: o sistema de regras interiorizado pelo falante (sua "gramática subjetiva”), em cuja base ele domina a língua em questão".
} 
Alguns questionamentos que essas reflexões suscitam:

- Até que ponto pode-se considerar a gramática um sistema de regras intrínseco à língua e independente de seu domínio por parte de seus falantes? Sem o supracitado domínio, de que modo seria possível justificar a existência mesma de tal sistema?

- Que nível de precisão terminológica podem oferecer escolhas verbais da sorte de "Grammatik im Kopf" ${ }^{46}$ ? Em que instância a gramática consistiria em fenômeno não mental? Onde se sustenta a existência desse sistema de regras senão, como anteriormente promulgado, depositado nas mentes dos falantes de uma língua?

- Em que consistiria exatamente a interiorização da "gramática subjetiva" depositada na mente de um falante, graças à qual possa este último dominar a língua? Refere-se Helbig à gramática adquirida de modo assistemático e espontâneo quando da aquisição das línguas maternas (e, em eventuais ocorrências, de aspectos de segundas línguas e não sem maiores discussões - das línguas estrangeiras?). Ou ao processo de apropriação sistemática de um sistema linguístico não-materno sustentado pelo estímulo à condução de processos cognitivos mediante o emprego de estratégias de ensino?

- Na discussão contemporânea acerca do tema, questiona-se o papel de falante ideal que antigamente se atribuía ao nativo de uma língua, como se esse não fosse passível de cometer erros, a partir de certas perspectivas, critérios e padrões ou modelos de linguagem considerados corretos em determinadas situações. Como comentam Montenegro; Oliveira (2011, p. 2),

\footnotetext{
o conceito de falante nativo seria dispensável, pois falante é aquele que vive, fala uma língua específica, mas que a partir do gerativismo de Chomsky se transformou em uma entidade dotada de uma competência perfeita, capaz de ser referência para o certo e o errado naquela língua. $\mathrm{O}$ estranho, personificado no falante nativo, possui a competência ideal da língua estrangeira que almejo falar e só ele poderia, portanto ser a minha referência e modelo a ser copiado.

Se pensarmos no processo de ensino e aprendizagem de línguas, esse pensamento pode ser problemático. Quando esse pensamento toma força e o falante nativo se torna a referência, o modelo em sala de aula a ser copiado, pode causar danos a seus aprendizes. Essa entidade chomskiana conquistou seu espaço nesse processo e gerou o que Rajagopalan chama de "apoteose do nativo" (2006). Mas esse modelo se torna inatingível no momento em que nos damos conta que tal competência
}

46 “Gramática na mente“ ou, literalmente, "na cabeça“. 
pregada por Chomsky não existe. ${ }^{47}$. [sic]

Clara está, retornando à questão das gramáticas, a despeito das dúvidas que desperta, a relevância do sublinhado teórico de um quarto significado para o vocábulo. Para tal, considera-se o esboço de Helbig um ponto de partida propício, ainda que não sem adaptações. Trata-se da consideração do processo de aprendizagem de uma descrição gramatical, incluídos os seus resultados. Entre eles, a representação implícita ou explícita do conjunto de regras que regem o funcionamento da língua e a formulação de enunciados e seu funcionamento na mente do aprendiz (JUNG, 1993).

Repetida menção encontra-se ainda, na literatura especializada, ao conceito há pouco anunciado de gramáticas didáticas ou pedagógicas, acerca das quais assevera Fliegner (1986, p. 12) que "sie sollen die maßgebenden Grundbegriffe der Grammatik möglichst für jeden Benutzer einer Sprache so verständlich erklären, dass er sie leicht auf alle Texte anwenden kann"48. Nas palavras de Krenn (2001, p. 82), nos últimos anos

hat sich die Forderung [nach einer 'pädagogischen' oder 'didaktischen' Grammatik für den Unterricht Deutsch als Fremdsprache] darauf beschränkt, die Anschaulichkeit und Lernwirksamkeit der Grammatikdarstellung in den Lehrwerken zu verbessern, wobei dieser Bereich wieder an Umfang und Bedeutung zugenommen hat. ${ }^{49}$

Por vezes, o conceito de gramática pedagógica (ou didática) é lançado por autores em oposição ao de gramática científica (NICKEL, 1993) ou gramática linguística (GNUTZMANN, 2001). Note-se, porém, que uma gramática didática ou pedagógica inexiste senão como fruto de uma adaptação intencional e sistemática de modelos teóricos de descrição gramatical desenvolvidos por linguistas, sem que tal adaptação implique perda

\footnotetext{
${ }^{47}$ Neste trecho, as autoras citam RAJAGOPALAN, K. O conceito de identidade em linguística: é chegada a hora para uma consideração radical? In: SIGNORINI, Inês (Org.). Lingua(gem) e identidade; elementos para uma discussão no campo aplicado. Campinas: Mercado das Letras, 2002.

48 “Elas devem explicar os conceitos normativos básicos da gramática para qualquer usuário de uma língua, de modo tão compreensível quanto possível, de forma que ele possa aplicá-los facilmente em todos os textos".

49 “A reivindicação (por uma gramática didática ou pedagógica para o ensino de alemão como língua estrangeira) restringiu-se a melhorar a visualização e a eficácia da explicitação gramatical nos livros didáticos, o que levou essa área a um crescimento em abrangência e importância”.
} 
necessária de rigor científico ${ }^{50}$. Ao contrário, ela exige o emprego consequente e dialógico de elementos oriundos de não poucas disciplinas, da ordem da Psicologia, das Ciências da Educação, da Sociologia, da Semiótica (quando se pretenda enquadrar de modo consciente a pluralidade de linguagens envolvida nos processos de didatização de fenômenos linguísticos) - exemplos não exaustivos. As gramáticas "linguísticas" e, por consequência, científicas, distinguem-se das pedagógicas à medida que perseguem o máximo aprofundamento possível na descrição de fenômenos linguísticos observáveis à luz de ampla gama de enfoques, desprovidas de motivação de perfil instrumental, pedagogizante ou funcional.

Funk \& König desmembram as funções de uma gramática pedagógica (em harmonia com os preceitos pragmáticos da abordagem comunicativa), de modo a realçar o papel do aprendiz, suas necessidades e conhecimentos prévios, como ponto de partida e como fim para sua confecção, onde se inclui a seleção de conteúdos a ensinar, bem como algumas características desejáveis nessas gramáticas, como o recurso a sistemas sígnicos auxiliares de feitio não-verbal:

Eine pädagogische Grammatik ist für uns [...] also mehr als eine Sprachbeschreibung. Sie meint eine Grammatikdarstellung, die ...

- ... zuerst die pädagogische Frage stellt, das heißt, sie fragt zuerst nach den Kenntnissen, Bedürfnissen und Voraussetzungen der Lerner. Auf dieser Grundlage werden Regeln ausgewählt und beschrieben.

-... Hilfen beim Lesen, Schreiben, Hören und Sprechen in der fremden Sprache gibt, aber nicht das Ziel des Unterrichts selbst ist.

-... im Gegensatz zur linguistischen Grammatik nicht in jedem Fall vollständige Systeme beschreiben und erklären will, sondern diejenigen Teile einer Regel oder eines Systems auswählt und beschreibt, die für einen bestimmten Verwendungszweck gerade gebraucht werden.

-... auch in der Präsentation von Regeln und Strukturen auf außerlinguistische Mittel zurückgreift, zum Beispiel auf Bilder, um Transparenz und Übersichtlichkeit zu vermitteln. $(1991, \text { p. } 13)^{51}$

\footnotetext{
${ }^{50}$ Assim, a gramática pedagógica ou pedagogização da gramática adapta ou simplifica, entre outras coisas, a terminologia metalinguística dos modelos gramaticais descritivos. Por exemplo, o que Eisenberg (1994) chama de "correlato", no contexto das orações relativas (item 1.1.2.1 deste trabalho), os autores do LD studio $d$ A2 denominam simplesmente um "nome" ou "substantivo" (item 2.3.1).

51 “Uma gramática pedagógica é, para nós, [...] mais que uma descrição linguística. O termo se refere a uma apresentação da gramática que:

- proponha a questão pedagógica, ou seja, que ponha em questão os conhecimentos, necessidades e pressupostos dos aprendizes. Com base nisso são escolhidas e descritas as regras.

- auxilie durante a leitura, escrita, compreensão auditiva e expressão oral na língua estrangeira, mas que não seja o objetivo da aula.

- ao contrário da gramática linguística, não descreverá e explicará, em todo caso, sistemas completos, mas sim que eleja aquelas partes de uma regra ou de um sistema que são utilizadas para um dado objetivo de utilização.
} 
Dada a inexistência de modelos teóricos de descrição gramatical elaborados expressamente com vistas à sua aplicação em contextos de ensino-aprendizagem comunicativo ou funcional de línguas (NICKEL, 1993, em consideração que se mantém atual, na área de $D a F$, após vinte anos), cabe aos componentes ativos do processo de filtragem pedagógica (a saber, autores de livros didáticos e, sobretudo, aos professores), a idealização e condução de suas próprias gramáticas pedagógicas ou pedagogizações gramaticais, tendo em vista seu conhecimento ímpar acerca das características e necessidades próprias de seus aprendizes e necessariamente munidos de vastos saberes, adquiridos e renovados por meio de processos de formação contínua e da prática profissional, advindos das distintas disciplinas envolvidas neste processo.

Assim sendo, com vistas à adaptação das reflexões aqui expostas para os propósitos dos estudos acerca da aprendizagem formal de gramática de línguas estrangeiras, propõe-se um modelo em que se estabelece um continuum entre quatro acepções principais de "gramática":

1. Gramática a priori ou gramática propriamente dita: um sistema limitado de regras interiorizado pelos falantes nativos de uma língua natural de modo concomitante e não mais que teoricamente indissociável do processo mesmo de aquisição da língua materna como um todo, que lhes possibilita a comunicação mediante a elaboração de infinitas sentenças nessa língua (CHOMSKY, 2002 [1957]);

2. Gramáticas científicas, linguísticas ou descrições gramaticais ${ }^{52}$ : modelos teóricos resultantes das atividades metalinguísticas descritivas desse sistema, de contorno científico e passíveis de transmissão a estudantes de língua materna, bem como de línguas não-maternas;

\footnotetext{
- também na apresentação de regras e estruturas recorra a meios extralinguísticos, por exemplo a imagens, para viabilizar transparência e visibilidade".

${ }^{52}$ Castilho (2010, p. 42) oferece um panorama de "pelo menos quatro direções" das teorias linguísticas e gramaticais: a descritiva, a funcionalista-cognitivista, a histórica e a prescritiva. Nesta dissertação, por se trabalhar com um modelo linguístico cristalizado assim como apresentado aos alunos pelos LDs e pelos professores (a declinação dos pronomes relativos alemães de acordo com a normativa do alemão-padrão), com um corpus e ao nível da sentença, adota-se uma perspectiva descritiva, o que não significa que não se considere a importância das demais perspectivas em trabalhos de outra natureza, acerca de outros recortes e construções fenomenológicos.
} 
3. "Gramática pedagógica", "filtro pedagógico" ou pedagogização de conteúdos de natureza gramatical, em contexto educacional, conduzida com a participação de atores como professor, aluno (autodidatas incluídos), livro didático, instituição de ensino e suas prescrições, método ou abordagem aplicados etc.;

4. Gramática formalmente adquirida, de apropriação consciente ou "do aluno": o registro das regras próprias (1) transmitidas sob o prisma do(s) modelo(s) teórico(s) estudado(s) (2) na mente dos aprendizes. Este registro constitui o objetivo último e o resultado da atividade pedagógica própria do processo de ensino e aprendizado de línguas para adultos, com vistas a facilitar aos estudantes de LE a formação de sentenças com propósito comunicativo na língua do outro, e, aos estudantes de língua materna, por sua vez, a análise de sua própria variedade linguística com finalidades múltiplas e/ou o domínio de um registro linguístico culto requerido em diversas esferas do convívio social. Em outras palavras, trata-se do desenvolvimento de competência gramatical por parte dos aprendizes.

Nesta dissertação trabalharei principalmente, portanto, entre os itens 3 e 4, ou seja, entre a gramática pedagógica e aquela adquirida, ou melhor, em processo de aquisição por parte dos aprendizes, quando se proceder, no capítulo 3 deste trabalho, à análise dos registros.

No terceiro subcapítulo desta parte da dissertação (1.3), serão apresentadas as abordagens de progressão de conteúdos gramaticais sintética e analítica, complementando estas reflexões sobre a gramática pedagógica e fundamentando teoricamente a aplicação dos testes que motivam a condução desta pesquisa. 


\subsubsection{O tópico gramatical: as Relativsätze}

Como anteriormente mencionado na introdução, o foco deste trabalho consiste nos processos de ensino-aprendizagem de uma estrutura gramatical específica, as Relativsätze, ou orações relativas alemãs, por parte de professores e aprendizes brasileiros. Neste item do texto, pretende-se descrever o funcionamento dessa estrutura e suas implicações e desdobramentos para o ensino e a aprendizagem. Trata-se, basicamente, de uma classe de orações subordinadas (Nebensätze $)^{53}$ de cunho atributivo, seja explicativo ou restritivo, correspondendo, grosso modo, às orações subordinadas adjetivas (relativas) explicativas e restritivas do português ${ }^{54}$.

Estudos empreendidos nos âmbitos psicolinguístico e cognitivista acerca da ordem de aquisição de estruturas morfossintáxicas do alemão (PIENEMANN, 1998), a verificar no capítulo 1.2.3.2, situam as Relativsätze ao final de um continuum de aquisição de estruturas oracionais, atestando, deste modo, seu alto grau de complexidade que, de fato, faz-se superior ao das demais estruturas congêneres.

Esse nível de dificuldade se explica, por sua vez, pelo número de estruturas gramaticais que devem ser previamente dominadas pelos aprendizes para que possam compreender e construir orações relativas em alemão. É útil e usual, para tal, que conheçam antes o funcionamento de outras orações subordinadas ou Nebensätze mais simples ${ }^{55}$, com sua típica colocação do verbo ao final, o sistema de declinação de artigos definidos, que se reflete no dos pronomes relativos, e as variações entre ambos (genitivos e dativos-plural).

\footnotetext{
${ }^{53}$ Cf. Helbig; Buscha (1988).

${ }^{54}$ Eisenberg (1994) menciona a problemática das orações que classifica como relativas, embora não sejam de cunho atributivo, uma vez que seu pronome introdutório (a princípio, relativo) não faz referência a nenhum elemento na oração principal. Essa questão não será abordada neste capítulo, uma vez que não se aplica ao corpus de orações trabalhadas com os alunos participantes da pesquisa.

${ }^{55}$ Por "Nebensätze mais simples" entendem-se aquelas que, introduzidas por um elemento gramatical invariável, uma conjunção, apenas implicam, em termos estruturais/gramaticais, e sob o ponto de vista do aprendiz de ALE, a colocação do verbo ao final. É fato que os livros didáticos de ALE as apresentam sistematicamente antes das Relativsätze.
} 
Nesse sentido ${ }^{56}$, é válido retomar a distinção krashiana entre saber a língua e saber sobre a língua. No capítulo de metodologia desta dissertação, descreveu-se o perfil dos participantes desta pesquisa, sua experiência geral com ensino e aprendizagem (não apenas de alemão e de outras línguas estrangeiras), seu nível socioeconômico etc., chegando-se à conclusão de que, no geral, trata-se de um grupo de alunos que não apresenta dificuldades acentuadas de aprendizagem. Isso quer dizer que, em sua grande maioria, os alunos em questão aprendem e dominam os insumos que lhes são ensinados enquanto conteúdos assimiláveis como estruturas lógicas a ser "compreendidas" e "memorizadas". A questão da automatização da estrutura "compreendida" é bastante distinta. Em grande número dos casos, o tempo de que se dispõe para trabalhar a lição/unidade do livro dedicada a esse tema gramatical é insuficiente para promover tal automatização, assim como a retomada da estrutura a cada poucas lições, a guisa de revisão, também parece, várias vezes, conduzir a resultados insatisfatórios. Essa questão deverá ser verificada, porém, na terceira parte deste trabalho, quando da análise dos dados obtidos junto aos informantes, bem assim nas considerações finais.

\subsubsection{A estrutura}

A tradução de Satz ao Português admite, em determinados contextos de tradução, os correspondentes "frase" e "oração". Se o significado do segundo termo parece menos obscuro e mais consensual entre especialistas, entendendo-se que uma oração está centrada ao redor de um verbo, o conceito proteiforme de "frase" continua sendo consideravelmente menos consensual $^{57}$. Interessa-nos, entretanto, o contexto oracional. Em Duden: Die Grammatik,

\footnotetext{
${ }^{56}$ Este parágrafo contém informações não advindas de pesquisa empírica, mas sim de experiência profissional com ensino-aprendizagem de alemão língua estrangeira.

57 Para diversos autores, trata-se de enunciados que expressam sentidos completos (CAMARA Jr., 1986; CUNHA; CINTRA, 1985; BECHARA, 2010; CEGALLA, 1988; ABAURRE et. al, 2003). Para Perini (1995), de modo irônico, a frase se caracteriza por uma letra maiúscula ao início e um sinal de pontuação ao final. Uma frase não necessitaria, deste modo, de um verbo, admitindo-se uma construção tal como "Ahhhhhh!” na categoria de frase. Essa problemática não está ausente das discussões alemãs acerca dos significados do termo Satz, um deles confundindo-se com o de frase. Como afirmaria Dürscheid (2007, p.57), “Wird der Satz [...] rein syntaktisch als eine Verbindung aus mehreren Wörten definiert, so ist zu fragen, ob Einwortsätze Sätze (vgl. Feuer!) darstellen. Diese Frage stellt sich auch dann, wenn man Sätze als eine grammatische Einheit aus Subjekt und Prädikat definiert. In einer orthographiebezogenen Definition wird der Satz als eine durch Interpunktion und Anfangsgroßschreibung markierte Einheit gesehen. [...] Interessant ist, dass im Englischen und Französischen - anders als im Deutschen - terminologisch ein Unterschied gemacht wird zwischen dem Satz.
} 
obra de referência alemã para questões de cunho gramatical (FLIEGNER, 1986), Satz corresponderia a "einen bestimmten grammatischen Bau; dieser ist haupsächlich vom Verb bestimmt: Das Verb eröffnet um sich herum Stellen für weitere Bestandteile des Satzes" (1998, p. 609). Nos livros didáticos de ALE adotados pelas escolas brasileiras ${ }^{58}$ desde os anos oitenta, tais como Themen/Themen neu, Deutsch aktiv/Deutsch aktiv neu, Moment mal!, Die Suche, Stufen, Berliner Platz, studio d, Schritte/Schritte International, etc., em concordância com a definição de Duden, as Sätze são apresentadas como estruturas definidas pela presença de um ou mais verbos, normalmente identificados como Verb 1 (principal), Verb 2 etc. (em caso de Satzklammer).

Sendo o verbo o tema, há-se de tratar daquilo que lhe é próprio no caso das orações relativas $^{59}$ : sua posição. Como nas demais Nebensätze (orações subordinadas), o verbo finito se localiza imediatamente ao final da oração que, por sua vez, é iniciada pelo pronome relativo (Relativpronomen). O pronome relativo (obrigatório, cf. EISENBERG, 1994) estabelece uma relação com um correlato (Bezugswort) na oração principal (substantivo, cf. ibid.), que é dependente do verbo, características que definem a oração relativa e a diferem de outros tipos de orações subordinadas (HELBIG; BUSCHA, 1988).

correlato

$\begin{array}{clcc}\text { Der da ist der Mann } & \text { den ich gestern aufdem Marktplatz gesehen habe. } \\ \text { oração principal } & \begin{array}{l}\text { pron. } \\ \text { rel. }\end{array} & \text { oração relativa } & \text { verbo }^{60}\end{array}$

als orthographische und dem Satz als grammatische Einheit. Die orthographische Einheit wird als , sentence“ (engl.) bzw. ,phrase ' bezeichnet, die grammatische Einheit als ,clause (eng.) bzw. ,proposition '(frz.)”.

${ }^{58}$ Faz-se referência às escolas, institutos ou academias de idiomas, às escolas públicas ou privadas em que o alemão consiste em disciplina obrigatória ou optativa e mesmo a universidades em que se ensine a língua alemã, em cursos livres ou de bacharelado/licenciatura.

${ }^{59}$ É ainda próprio das orações relativas alemãs, no âmbito da pontuação, o fato de encontrarem-se sempre cercadas de vírgulas ou entre vírgula e ponto final.

${ }^{60}$ Decidiu-se por sinalizar o verbo principal/finito, ou seja, o verbo que foi lançado ao final da frase, de forma a ilustrar a definição e a estruturação da oração relativa, a sabendas de que gesehen forma parte do tempo verbal em questão (Perfekt) e encontra-se reunido com o auxiliar. 
Assim, o pronome relativo, item gramatical que introduz e também caracteriza a Relativsatz, correspondente, de modo literal, às formas portuguesas "que”, “o qual”, "a qual”, “os quais", "as quais", “cujo", "cuja”, "cujos" e "cujas"61, responde a uma extensiva tabela de declinações, totalizando 16 formas $^{62}$, algumas repetidas, embora em posições e funções diferentes. A declinação dos pronomes relativos costuma apresentar dificuldades ao aprendiz brasileiro, acostumado ao uso generalizado do "que"63 e, a depender de seu socioleto, à recursividade.

A declinação dos pronomes relativos alemães responde aos parâmetros gênero, número e caso. É evidente que a maior dificuldade para os nossos alunos reside neste último elemento, uma vez que se ausenta da língua portuguesa e frequentemente tem sua "utilidade" não assimilada pelo aprendiz. Como observa Figueiredo, R. (2007, p. 77),

tenho verificado que uma das principais dificuldades apontadas pelos alunos no processo de aprendizagem desta língua refere-se a questões ligadas à declinação das palavras. Os motivos (relatados pelos alunos) mais citados como possíveis causas de tais dificuldades podem ser categorizados em dois tipos de afirmações: a) "Nunca estudei latim ou qualquer outra língua declinável", e b) "Português não se declina, daí minha dificuldade".

Além disso, a questão do gênero permanece sendo um desafio para o estudante, já que exige memorização ${ }^{64} \mathrm{e}$, em relevante parte das ocorrências, foge de qualquer lógica ou padronização.

O ensino dos pronomes relativos, evidentemente concomitante com o das Relativsätze, é sempre ${ }^{65}$ posterior ao da declinação dos artigos definidos, sendo que ambas as tabelas

\footnotetext{
${ }^{61}$ E "o que", "onde”, “quanto" e um largo etc.

${ }^{62}$ Refiro-me às formas que são apresentadas aos alunos nos livros didáticos em que se baseia esta pesquisa. Não farei referência às variações de welch-, wessen, wor- etc., e o que Helbig; Buscha (1988) chamam de Interrogativpronomen com valor de Relativum como wer, was etc.

${ }^{63}$ É relevante lembrar que, em algumas regiões da Alemanha, fenômeno similar ocorre. Trata-se do emprego do pronome relativo "wo" em certas variantes dialetais, e ausente das gramáticas normativas do Hochdeutsch, no lugar das formas convencionais der, den, dem, die, etc. Essa variação não foi, entretanto, apresentada aos alunos informantes desta pesquisa pelos professores-voluntários.

${ }^{64}$ Artigo + substantivo.

${ }^{65}$ Tomando-se por base minha observação de mundo e os LDs mencionados anteriormente neste capítulo.
} 
guardam enormes semelhanças e pode consistir em estratégia (docente ou discente) a comparação entre ambas. Observe-se:

Tabela 1 - Artigos definidos (Bestimmte Artikel) do alemão

\begin{tabular}{|l|l|l|l|l|}
\hline & MASCULINO & FEMININO & NEUTRO & PLURAL \\
\hline NOMINATIVO & der & die & das & die \\
\hline ACUSATIVO & den & die & das & die \\
\hline DATIVO & dem & der & dem & den \\
\hline GENITIVO $^{66}$ & des & der & des & der \\
\hline
\end{tabular}

Tabela 2 - Pronomes relativos (Relativpronomen) do alemão (relativos-d) ${ }^{67}$

\begin{tabular}{|l|l|l|l|l|}
\hline & MASCULINO & FEMININO & NEUTRO & PLURAL \\
\hline NOMINATIVO & der & die & das & die \\
\hline ACUSATIVO & den & die & das & die \\
\hline DATIVO & dem & der & dem & denen \\
\hline GENITIVO & dessen & deren & dessen & deren \\
\hline
\end{tabular}

Uma análise estrita de ambas as tabelas resultaria num grau de semelhança de aproximadamente $69 \%$, tendo-se como critério a ocorrência de lexemas idênticos. Uma análise menos rigorosa poderia resultar em 100\% de semelhança, considerando-se "des" altamente próximo de "dessen", "deren" uma variação de "der" 68 etc. No processo de ensinoaprendizagem, é possível aludir a alguns fenômenos gramaticais para chamar a atenção ao parentesco entre os artigos definidos e os pronomes relativos. Por exemplo, imagine-se o caso do dativo-plural do alemão. Nessa ocorrência específica da língua, o artigo correspondente é "den" e o substantivo recebe um "- $n$ " ao final. Das Bild (nominativo), den Bildern (dativo-

\footnotetext{
${ }^{66} \mathrm{O}$ genitivo não forma parte da pesquisa experimental e se encontra na tabela com propósito exemplificativo, uma vez que seu ensino-aprendizagem não será investigado.

${ }^{67}$ Em negrito, as formas que diferem entre as duas tabelas. "Relativos-d" referem-se aos "d-Pronomen" de Rottweiler (1993), em adaptação minha.

${ }^{68}$ Estas considerações não se baseiam em estudos linguísticos diacrônicos, i.e., não se está afirmando que os pronomes relativos derivem factualmente dos artigos definidos, e sim, dada a natureza e a preocupação didáticopedagógica deste trabalho acerca do ensino-aprendizagem de ALE, e mais especificamente das Relativsätze, que tal consideração pode ser de valia para o ensino como estratégia de associação e analogia.
} 
plural). Faz-se válido demonstrar ao aluno que esse "- $n$ " extra ressurge no pronome relativo correspondente (dativo-plural): den Bildern $\rightarrow$ denen, e o mesmo com des Bruders $\rightarrow$ dessen.

Quanto à tipologia das orações relativas alemãs, Bußmann (2008, p. 584) distingue dois tipos a partir de uma perspectiva focada na função semântico-pragmática: orações relativas restritivas e não restritivas (estas últimas também denominadas explicativas ou apositivas). As primeiras

schränken die Menge der möglichen Referenzobjetkte des durch den R. spezifierten nominalen Ausdrucks ein (Hier ist das Buch, das du gesucht hast (und kein anderes Buch als dieses)), während nicht-restriktive $R$. das (bereits identifizierte) Bezugsnomen genauer spezifizieren (Napoleon, der bekanntlich aus Korsika stammt, wurde nach Elba verbannt) [...] außerdem sind nicht-restriktive $R$. fakultativ, restriktive aber obligatorisch. ${ }^{69}$ (BUSSMANN, 2008, p. 584)

Isso mostra que, semanticamente, as orações relativas desempenham, em alemão, funções semelhantes às que lhe cabem no português, da ordem da especificação ou detalhamento acerca de um elemento da oração principal, e, mais especificamente, da ordem da explicação e da restrição, semelhança que facilita o processo de aprendizagem, malgrado as diferenças morfossintáticas dessas construções nesse par de línguas (posição do verbo e flexão/declinação do pronome relativo). Como nos lembra Figueiredo, F. (1995, p. 41), “aprender uma L2 que seja parecida com a L1 não é o mesmo que aprender uma língua que seja completamente diferente". Como exemplos de línguas parecidas, o autor menciona pares de parentesco evidentemente mais próximo, como búlgaro/russo e português/espanhol, mas é notório que, no tocante às orações relativas, o alemão e o português, ambas línguas indoeuropeias, ainda que de famílias diferentes, resguardam importantes similaridades que auxiliam no processo de ensino-aprendizagem. Apesar disso, como se observará na análise dos dados, o fato de praticamente todos os pronomes relativos alemães que constam da tabela apresentada aos aprendizes poderem ser traduzidos ao português como "que"70 abre brechas para interferências e uma menor diferenciação, por parte de brasileiros, da variedade de

\footnotetext{
69 "restringem a quantidade dos possíveis ojetos de referência da expressão nominal especificada pela oração relativa (aqui está o livro que você procurou (e nenhum outro além desse)), enquanto as orações relativas não restritivas especificam mais precisamente o (nome) correlato (já identificado) (Napoleão, que como se sabe vem da Córsega, foi exilado em Elba) [...] além disso, as orações relativas não restritivas são facultativas, e as restritivas, obrigatórias.

${ }^{70}$ A esse respeito, Camara Jr. (1997, p. 258) elucida: "O pronome relativo, por excelência, em português é a partícula que, proveniente nesta função do pronome relativo latino qui-quae-quod [...]. A partícula que, isolada ou regida de preposição, conforme a sua função, pode servir, latamente, como sujeito, complemento ou adjunto na sua oração subordinada".
} 
relativos-d presentes no alemão. Os professores-voluntários desta pesquisa declaram, como se pode observar nos registros do apêndice, valer-se do contraste alemão/português para ensinar/explicar a seus alunos como funcionam as relativas alemãs.

Como será observado no terceiro capítulo dos pressupostos teóricos deste trabalho, a complexidade que as Relativsätze impõem ao processo de ensino-aprendizagem faz que professores e coordenadores de cursos de alemão reflitam sobre as formas mais eficazes de apresentarem tais conteúdos aos seus aprendizes. Isso influi na escolha de livros didáticos, os quais apresentam os conteúdos gramaticais a partir de diferentes princípios de progressão. Adiante verificaremos se um dos tipos de progressão levará os estudantes a uma maior assimilação das estruturas, ou como se perfilará a produção dos informantes pertencentes a cada grupo de informantes. 


\subsubsection{Gramática: entre erros, acertos, compreensibilidade e funções}

To err is human, to forgive, inevitable. Otherwise there would be no human activity possible. The surest way to avoid making errors is to do nothing, and even that offers no guarantee of infallibility. ${ }^{71}$ (BENNETT, 1974, p. 228)

Avulta a necessidade de desenvolver uma forma de ensino em que os erros sejam vistos não como um 'obstáculo' para o sucesso dos alunos, mas como um 'trampolim' para chegar à proficiência na língua-alvo. (FIGUEIREDO, F., 2004, p. 121)

A questão do erro permeia grande parte da bibliografia acerca do ensino-aprendizagem de LE, e a ela foram dedicados inúmeros trabalhos ao longo das últimas décadas. Trata-se de uma relevante questão que não pode ser negligenciada nesta dissertação, uma vez que, aqui, procede-se à correção e avaliação de exercícios realizados pelos alunos-informantes. Neste capítulo, devido à natureza desta pesquisa, serão sublinhadas, mormente, as questões envolvidas no processo de compreensão e correção de erros em amostras linguísticas escritas, com eventuais menções mais gerais às questões do erro na produção oral. Antes de adotar uma definição de erro e de estabelecer critérios para seu entendimento, pretende-se traçar um pequeno histórico acerca da noção e do tratamento ou gerenciamento do erro sob o predomínio de perspectivas teóricas distintas.

Isso porque o erro vem sendo encarado sob o prisma de diferentes visões, cuja dominância foi-se alternando ao longo do tempo. Liberali (1994), de forma sucinta, menciona os paradigmas behaviorista, naturalista e sócio-construtivista de abordagem e tratamento ${ }^{72}$ do erro. De acordo com o primeiro dos três, o aprendizado é condicionado por sequências de estímulo e resposta, num "processo mecânico de formação de hábitos" (op. cit., p. 3). Os erros devem ser evitados mediante a aplicação de exercícios de repetição (drills) e a sua correção imediata por parte do professor, eventualmente gerando, junto aos alunos, ansiedade e o medo de errar. O naturalismo, por sua vez, veio marcado pelas noções chomskianas do inatismo e

\footnotetext{
71 "Errar é humano; perdoar, inevitável. De outro modo, não haveria atividade humana possível. O meio mais seguro de evitar cometer erros é não fazer nada, e nem mesmo isso oferece garantias de infalibilidade”.

72 Aqui relembramos Allwright \& Bailey (1991 apud MESQUITA, 2008), que sugerem deliberadamente a utilização do termo "tratamento" de erros, em detrimento da variedade (diga-se, mais comum na linguagem corrente) "correção", uma vez que esta última aludiria a uma noção de "cura", algo que não se observa junto aos aprendizes após a correção efetuada pelos professores. Bimmel et al. (2011, p. 166), por sua vez, empregam o termo "Fehlerterapie", ou terapia de erros.
} 
do dispositivo de aquisição da linguagem (DAL): "a criança adquiriria a língua dedutivamente do ambiente que forneceria o input para ser analisado pelo DAL" (p. 4). Além disso, Chomsky propôs os conceitos de competência ("conhecimento idealizado de um falante ideal dentro de uma comunidade linguística homogênea") e desempenho ("uso real da língua em situações concretas" (idem). No contexto de LE, surge a interlíngua de Selinker (1972), ${ }^{73}$ que propôs a inevitabilidade da presença do erro no processo de ensino-aprendizagem, do qual seria parte indissociável. A ocorrência de erros forneceria informações sobre o processo de aprendizagem dos alunos e funcionaria como teste de hipóteses por parte deles (CORDER, 1967). Surge assim a diferença entre erros ("errors") e enganos ("mistakes"), sendo os primeiros de ordem sistemática e cometidos devido a desconhecimento, e os segundos, devido a lapsos de memória e descuidos daquilo que os alunos já dominavam, situando-se no nível do desempenho e devendo ser corrigidos pelos próprios aprendizes (CORDER apud LIBERALI, $1994)^{74} 75$. No paradigma naturalista, pouco se valorizaram o papel da interação e do outro no processo de aprendizagem e, por extensão, de compreensão dos erros, o que tornou os professores inseguros quanto à forma de tratá-los - e os alunos, quanto ao próprio aprendizado. Já no sócio-construtivismo, incluiu-se a questão da interação, negligenciada nos dois paradigmas anteriores, considerada agora essencial e intrínseca ao ato comunicativo. Surgem o conceito de mediação, "crucial para essa visão" (op. cit., p. 5) e as noções vygotskianas de processos de desenvolvimento inter e intrapessoais. Nos primeiros, a apropriação do conhecimento dar-se-ia mediante o apoio no outro e na interação com ele. Nos segundos, "o indivíduo já teria construído internamente o conhecimento e não mais dependeria do outro" (idem, ibidem). Aqui, o erro não seria mais encarado como simples interferência, supergeneralização ou simplificação, passando a constituir uma "tentativa do

\footnotetext{
${ }^{73}$ Verifique-se tabela 3 no item 1.2.2 do trabalho.

${ }^{74}$ Edge (1989 apud BIANCHINI, 2007, p. 2) propõe uma divisão parecida entre "errors" e "slips", estes últimos semelhantes ao conceito de mistakes de Corder, e adiciona um terceiro tipo: os "attempts", que ocorrem quando o aluno tenta se comunicar lançando mão de tentativas, ao tentar manipular estruturas e vocabulário ainda não formalmente aprendidos. Pode-se dizer que os attempts são testes de hipóteses e podem ocorrer na produção escrita dos aprendizes. Ainda segundo Bianchini (idem), Richards classificou os erros em interlinguísticos, intralinguísticos e evolucionários. Os primeiros decorreriam de influências da LM dos aprendizes, os segundos "podem ser causados pela influência de um item da língua-alvo sobre o outro" e os últimos, por sua vez, decorrem do levantamento de hipóteses pelo aprendiz, "tendo como base sua experiência limitada em sala de aula ou o uso do livro didático" (op. cit.). Kleppin (1998, p. 42), com base em Edge, também remete a essa tipologia tripartite, referindo-se a Ausrutscher ("slips"), Irrtümer ("errors") e Versuche ("attempts"). Referindose aos "errors", a autora também nos fala de erros de competência ("Kompetenzfehler") e, mediante o emprego do termo "Performanzfehler", refere-se a tipos de erros ("Verstöße") que podem ser corrigidos pelos próprios alunos, e os divide em enganos ("mistakes") e lapsos ("lapses").

75 Bianchini (2007) nos lembra que, segundo Ellis, os alunos são capazes de corrigir seus enganos, mas não os seus erros.
} 
aprendiz de adquirir controle sobre a tarefa" (idem, ibidem). Ao tratar o erro, o professor, nesta perspectiva, deveria provocar a autocorreção por parte do aprendente. $\mathrm{O}$ aluno depende, primeiramente, da intervenção do outro para atuar na correção dos próprios erros, mas adquiriria, com o tempo, maior independência nesse processo ${ }^{76}$.

Quanto ao tratamento dos erros, Allwright \& Bailey (1991, apud LIBERALI, 1994) propuseram a seguinte tipologia: a) erros autopercebidos e heterocorrigidos; b) erros autopercebidos e autocorrigidos; c) heteropercebidos e autocorrigidos e d) heteropercebidos e heterocorrigidos. No contexto desta pesquisa, e devido ao formato das amostras de produção linguística coletadas (escritas) e à metodologia de trabalho (os textos foram corrigidos e avaliados pelo pesquisador), tem-se intrinsecamente um contexto de erros heteropercebidos e heterocorrigidos $^{77}$, embora, no dia-a-dia de cursos de ALE, o professor possa sinalizar a presença de erros no texto escrito para posterior autocorreção por parte dos próprios alunos.

Bianchini (2007) nos lembra as funções dos erros segundo Corder: a) informam ao professor o estágio atual do progresso do aluno na aprendizagem da LE; b) dão evidências ao pesquisador a respeito do mesmo processo e, também, c) informam acerca das estratégias de que o aprendiz faz uso nesse processo.

Tendo isso em vista, adotarei o trabalho Aprendendo com os erros: uma perspectiva comunicativa de ensino de línguas, de Francisco Figueiredo (2004), como base para definir e entender a noção de erro que norteará a análise dos dados, a ser empreendida no capítulo 3 deste trabalho, ainda que num cotejo com textos de outros autores. Esta decisão se deve ao fato de que o texto de Figueiredo, cujas propostas estão plenamente integradas a uma abordagem comunicativa do processo de ensino-aprendizagem de LE, também

pretende contribuir para a realização de uma prática pedagógica mais adequada de segunda língua, por apresentar ao leitor uma fundamentação teórica que facilita e viabiliza a compreensão do processo de ensino-aprendizagem, bem como por mostrar algumas abordagens sobre a concepção de erro, seu efeito na comunicação,

\footnotetext{
${ }^{76}$ Embora se possa dizer que, em muitos sentidos, os paradigmas de abordagem da temática dos erros superaram aspectos limitados dos anteriores, como no caso do sócio-construtivismo incorporando as questões da interação e do outro, ausentes no behaviorismo e no naturalismo, algumas noções mais antigas, como as propostas de Corder, são empregadas em trabalhos acadêmicos relativamente recentes que focalizam a questão do erro em LE, principalmente quando enfocam a relação LM/LE (como exemplo, STANICH, 2000; FIGUEIREDO, F., 2004; SILVA, C., 2006 e SANTOS, A., 2006, entre vários outros).

${ }^{77}$ Podendo-se incluir: heterointerpretados.
} 
e oferecer algumas sugestões de como lidar com o erro em sala de aula. Os capítulos foram elaborados de forma a encorajá-lo a adotar uma atitude positiva em relação aos erros e a vê-los como um fato importante e útil dentro de todo esse processo. Por trás dos erros, existe um mundo de estratégias que o aprendiz utiliza e que deve ser explorado e compreendido, tanto pelo professor quanto pelo próprio aprendiz. (FIGUEIREDO, F., 2004, p. 12)

Iniciando pelas tentativas de definição de erro, Figueiredo nos lembra, desde o início, da complexidade dessa tarefa, uma vez que depende, entre outros fatores, da teoria linguística adotada para abordar esse fenômeno. $\mathrm{O}$ autor começa pela menção a Ilari e Possenti, que associam à noção de erro a questão da normatividade, i.e., o erro corresponderia a uma fuga às prescrições da gramática normativa, baseada numa variedade linguística convencionalmente tida como padrão e certa. Esses autores também mencionam "o erro que decorre da gramática descritiva, elaborada por linguistas. Nessa perspectiva, o erro é a ocorrência de formas ou construções que não fazem parte, de maneira sistemática, de nenhuma das variedades de uma língua" (ILARI e POSSENTI apud FIGUEIREDO, F., 2004, p. 45 , itálicos do original).

O estudioso cita também Lennon, que "considera o erro em L2 como uma forma linguística - ou combinações de formas - que, no mesmo contexto e sob condições semelhantes de produção, não seria, de maneira alguma, produzida pelos falantes nativos" (op. cit., p. 46) ${ }^{78}$. Muito importante é a referência a Chastain e Piazza, pesquisadores que consideram que nem sempre o erro afeta a comunicação. Assim, Figueiredo, F. (2004, p. 46) se posiciona: "consideraremos como erro a forma que, independentemente da construção gramatical, impede o processo de comunicação. Nessa perspectiva, formas como 'nós foi' ou 'he like' [ele gosta] não seriam consideradas erradas, pois, além de existirem na variedade não-padrão do português e do inglês, respectivamente, não comprometem a significação da mensagem" (idem, ibidem). O autor aponta outra questão muito relevante e diretamente associada à temática da (a)gramaticalidade dos enunciados: "uma sentença bem construída gramaticalmente pode ser formada por um amontoado de palavras que não têm significação alguma, impedindo, pois, a comunicação", de modo a depositar especial importância à questão semântico-pragmática-funcional quando da avaliação/correção da produção linguística de aprendizes de LE.

\footnotetext{
${ }^{78} \mathrm{O}$ autor optou por empregar, em seu estudo, de forma generalizada e de acordo com a literatura de linha norteamericana, a expressão L2. No presente trabalho, diferentemente, e como especificado na introdução, será utilizada a forma "LE".
} 
Faz-se importante ressaltar, neste ponto, que o trabalho de Figueiredo, embora me sirva de fio condutor para a questão da abordagem do erro, tem como norte o nível do texto (também abordado neste trabalho), no seio do qual o erro gramatical é um elemento entre vários, podendo interferir ou não na comunicação. Nesta pesquisa, entretanto, dedico-me à avaliação não apenas de textos, mas também de exercícios (mais) reprodutivos ${ }^{79}$ que têm como foco especial a gramática (no caso, a construção das orações relativas do alemão). Numa atividade, à guisa de exemplo, que enfocasse especificamente a gramática e consistisse na proposta de que o aluno preenchesse lacunas com o pronome relativo pertinente, devidamente flexionado e em concordância com o gênero e número do correlato na oração principal, ao qual se refere e o qual descreve, especifica ou restringe, o critério de correção seria a gramaticalidade da resposta, ou seja, se o pronome indicado seria o considerado correto ou não, ainda que também se considere a compreensibilidade. Também no caso de orações relativas inseridas em textos, ou no caso de sentenças completadas e contextualizadas pelos aprendizes, impõe-se-nos a necessidade de considerar a comunicação, mas também a correção gramatical das sentenças construídas pelos informantes.

Neste ínterim, cumpre definir o registro linguístico a ser adotado como padrão para os propósitos da correção das amostras de produção que coletamos junto aos aprendizes. Kleppin (2000) alerta para a dificuldade de se estabelecer uma norma linguística a ser tida como correta e independente dos diferentes falares individuais, regionais e de variações associadas a estratos sociais. Outros critérios eventualmente usados para a determinação do que seriam erros e acertos, além de uma variante linguística arbitrariamente ideal, seriam, de acordo com a autora, a compreensibilidade, a adequação situacional-cultural, uma consideração flexível centrada em alunos individuais, de modo a enfocar o aprendiz e suas possíveis dificuldades, e/ou, por fim, um padrão definido pelas aulas específicas (ou, acrescento, o curso), tais como o LD, a gramática utilizada ou as decisões do professor. Este último aspecto será de especial interesse para esta pesquisa, por razões que serão discutidas mais adiante.

Nesse sentido, Figueiredo, F. (2004) aponta para a necessidade de reflexão acerca da língua utilizada nos livros didáticos, “que, até certo ponto, é idealizada, cristalizada, diferente da realidade de seus falantes". Para o autor, "é aconselhável expor os alunos a outras

\footnotetext{
${ }^{79}$ Verifique-se a tipologia de exercícios adotada na parte 2 desta dissertação. Quando falo em exercícios mais reprodutivos, refiro-me ao fato de que a escala de exercícios de A a D é determinada por uma tendência crescente rumo ao caráter mais produtivo das atividades, encontrando-se, porém, em todas elas, inclusive nas chamadas produtivas, assim como abordadas neste trabalho, características de reprodução.
} 
variedades linguísticas usadas pelos falantes nativos" (2004, p. 132). E, como afirma Spiekermann (2010, p. 355), "der DaF-Unterricht hat auf die Forderung einer stärkeren Berücksichtigung regionaler Varietäten bislang nur zögerlich reagiert, zumindest wenn man nach den Themen und Übungen in gängigen DaF-Lehrwerken geht" ${ }^{80}$ Apesar de estar de acordo, de modo geral, com essas observações, é fundamental considerar que esta investigação não apenas envolve o emprego do LD, mas também engloba, como tratado na introdução e no item 1.4, a questão do uso que os professores-voluntários efetivamente fazem do manual adotado.

Como se alertou na introdução, este estudo não visa, entre seus objetivos, a uma transformação das práticas docentes dos colaboradores, mas sim a uma análise de amostras de produção linguística de aprendizes que frequentaram os dois cursos em que ocorreu a coleta. Dando-se o caso de que os professores-voluntários, assim como declarado por eles e registrado no anexo, adotam o modelo linguístico das orações relativas oferecido pelos LDs studio d A2 e Schritte International $5^{81}$ e não exploram em sala de aula outras variantes linguísticas do uso dos pronomes relativos no alemão falado atual, ao menos nos níveis A2 e B1 do QECR, teremos como norte as tabelas de pronomes relativos que figuram nos dois LDs e que foram descritas nesta dissertação, no item 1.1.2, correspondentes ao "Hochdeutsch" ou alemão-padrão, e assim apresentadas aos alunos. A sabendas de que a sociedade alemã é consideravelmente letrada, e de que o Hochdeutsch é ensinado em virtualmente todas as escolas da República Federal da Alemanha, sendo língua de veiculação dos conteúdos das demais disciplinas e ainda a variedade linguística oficialmente empregada nas salas de aula das universidades dos países de língua alemã, bem como na comunicação social, oral e escrita, através dos meios de comunicação de massas, deve-se considerar que a gramática apresentada aos aprendizes que estudam alemão com esses LDs não se pode considerar exatamente distante da realidade quotidiana da expressão nas nações germanófonas, ainda que se considerem as variações observáveis nos diferentes dialetos e socioletos que também

\footnotetext{
80 "Até o momento, a aula de alemão reagiu apenas hesitantemente à exigência de uma consideração mais forte das variedades regionais, ao menos quando se trata dos temas e exercícios nos livros didáticos contemporâneos de ALE”. Meus agradecimentos à Profa. Dra. Dörthe Uphoff por esta contribuição, entre inúmeras outras.

${ }^{81}$ E que, conforme verifiquei, é o mesmo empregado por todos os LDs adotados por todas as escolas de idiomas que oferecem cursos de alemão no Estado de São Paulo parceiras do Instituto Goethe (verifique-se listagem no apêndice 1a).
} 
compõem o que se entende atualmente por língua alemã ${ }^{82}$. Além disso, na tradição de ensino de ALE no Brasil em cursos livres para adultos, costuma-se invariavelmente ensinar aos aprendizes o alemão-padrão como modelo, ainda que os LDs (como os utilizados nesta pesquisa) incluam atividades eventuais de sensibilização a outras variedades linguísticas do alemão, mas não visando à capacitação do aluno para se expressar nessas variedades, ou seja, para produzir linguagem em dialetos. Quites (1997, p. 7) retoma um estudo de Chavez (1984, p. 321) com aprendizes de alemão nativos de inglês e, referindo-se à questão das declinações, afirma que "embora nem todas as declinações incorretas cheguem a bloquear a comunicação, é interesse de todo aluno de Alemão como Língua Estrangeira declinar conforme o alemão padrão" ${ }^{83}$

Neste ponto, convém mencionar que um tema a surgir com frequência nos discursos elaborados pela comunidade científica acerca de erros é a questão da fossilização. Cruz ${ }^{84}$ (apud CAVALARI, 2008, p. 49) inclui a referência ao termo em sua definição de interlíngua:

Interlíngua é a competência lingüístico-comunicativa que o aprendiz de língua estrangeira manifesta em sua produção, marcada pela variabilidade, num percurso com avanços, regressões, instabilidade e possíveis fossilizações até o estágio final. Além das transferências lingüísticas, ocorre a criação de regras próprias a esse sistema. $[\text { sic }]^{85}$

O termo "fossilização" 86 se refere a formas presentes e recorrentes na interlíngua (IL) do aluno consideradas errôneas e que tenham se estabilizado em sua produção, geralmente

\footnotetext{
${ }^{82}$ Não ignorando as muitas regiões germanófonas na Europa em que os nativos se expressam primariamente no dialeto local, mas utilizam o Hochdeutsch, ainda que com cor local, ao expressar-se com falantes de alemão (LM ou LE) não-nativos de sua região.

${ }^{83}$ Sic, com itálico e sublinhado da autora. Entende-se que a parte em itálico corresponde à citação de CHAVEZ, M. English native speakers reading German; Syntactic versus semantic problems ans strategic behavior. IRAL, $\mathrm{n}^{\circ}$ 32, v. 4, nov. 1994.

${ }^{84}$ CRUZ, M. L. O. B. Estágios de interlíngua; estudo longitudinal centrado na oralidade de sujeitos brasileiros aprendizes de espanhol. Tese (Doutorado em Linguística Aplicada). Campinas: IEL/Unicamp, 2001.

${ }^{85}$ Sobre essa variabilidade, Ladmiral (apud JOVANOVIC, 1986, p. 150) afirmava: “L'apprentissage d'une langue étrangère passerait donc par une succession de destructurations et de restructurations successives de la compétence mise em place (...) Cette succession de grammaires internes intermédiares será bien sûr plus rapide au debut de l'apprentissage, qui part du zero; mais, dans l'état actuel de nos connaissances, on ne sait rien de précis sur le déroulement effectiv de ce processus, qui fait partie de la fameuse 'boite noire' des psychologues".

${ }^{86}$ Um termo comumente associado à fossilização é "recaída". Segundo Percegona (2005, p. 7), "para Selinker (1992, p. 226), a recaída é o ressurgimento súbito de um sistema da IL há muito ausente do desempenho de fala do aprendiz, reutilizando estruturas que pareciam estar erradicadas. Por exemplo, um aprendiz de inglês parece entender perfeitamente o uso do "s" na terceira pessoa do singular no presente simples, mas ao usar esta estrutura em um momento de fala, ele apresenta uma recaída e erra."
} 
sob a forma de "regras e subsistemas típicos da língua nativa" (op. cit.) que persistem na interlíngua do aprendente.

Como nos elucida Fernández (2011, p. 8),

a interlíngua designa o sistema lingüístico do aprendiz, e não corresponde nem à sua LM nem à língua que está aprendendo. Caracteriza-se pela instabilidade, ou seja, é entendida como um continuum, já que passa por estágios de desenvolvimento, com avanços e retrocessos, na sua tentativa de aproximação da língua-alvo, e recebe influências não só da LM, mas de outros fatores, inclusive da própria interlíngua.

De acordo com Selinker (1972, p. 34), somente 5\% dos falantes consegue desenvolver uma competência comunicativa de sucesso, similar à de um falante nativo. [sic]

Porém, Cavalari (2008, p. 49), referindo-se novamente a Cruz (2001), prossegue mencionando a possibilidade de superação de itens considerados fossilizados:

Cruz (op.cit.) aponta a possibilidade de superação desse aspecto "invariável" em função de futuras experiências advindas na língua-alvo, da motivação e de outras variáveis (p.53), ou seja, é possível que um item fossilizado possa ser superado, dadas as oportunidades para que o aprendiz perceba essa lacuna em sua IL e assuma uma atitude positiva nesse sentido.

No tocante à IL dos alunos, Figueiredo, F. (2004) procede a uma catalogação dos erros em quatro grupos maiores, a saber, os interlinguais, os intralinguais, os ambíguos e os induzidos ("transfer of training"). Tratarei, abaixo, dos quatro tipos separadamente.

Os erros interlinguais, "também chamados erros de interferência ou transferência" 87 , seriam aqueles motivados pela interferência da LM, "sem, contudo, serem considerados negativos" (FIGUEIREDO, F., 2004, p. 52) ${ }^{88}$. Suas causas seriam:

\footnotetext{
87 Kleppin (1998) nos fala, numa categorização de erros interlinguais, em supergeneralização (“Übergeneralisierung" - extensão de uma regra a contextos linguísticos nos quais ela não se aplica), regularização ("Regularisierung" - quando um fenômeno linguístico irregular é tratado como regular, ou regularizado) e simplificação ("Simplifizierung” - simplificação de formas, por exemplo, a não conjugação e evitar estrutras complexas como as subordinadas).

${ }^{88} \mathrm{O}$ autor não menciona, quando da alusão aos erros interlinguais, a influência de outra língua estrangeira previamente estudada pelo aluno quando da produção em LE, ou seja, ignora o contexto de aprendizagem de L3. No meu juízo, esse tipo de erro também pode ser considerado quando da análise da produção escrita dos aprendizes, embora essa questão não seja abordada neste trabalho, à falta de evidências a respeito oferecidas pelos dados. Para mais detalhes sobre a aprendizagem do alemão após a do inglês, cenário muito comum entre estudantes de ALE no Brasil, veja-se Ferrari (2012).
} 
a) Extensão por analogia: o vocábulo é usado incorretamente porque compartilha traços fonológicos, semânticos, sintáticos ou ortográficos com outro da LM. Encaixam-se nesta categoria a extensão semântica de um vocábulo da LM, a semelhança ortográfica e/ou fonológica com a LM, o apoio no sistema gráfico da LM, ou no sistema fonético/fonológico e gráfico dela. Um exemplo extraído de nosso corpus é a formulação "Das ist der Mann, den ich ein Kind habe” (Inf. 1, Grupo A, atividade B1) em vez de "... mit dem ich ein Kind habe", possivelmente ocasionado pela generalização do uso do "que", em expressões oralizadas, como pronome relativo em português, e pelo uso cada vez mais rarefeito das relativas preposicionadas no Brasil (“esse é o homem que eu tenho um filho”);

b) Não-distinção lexical na $\mathrm{LM}$, em relação à $\mathrm{LE}^{89}$, vária vez gerada pela consulta de vocábulos no dicionário, onde não ficam sempre claros os contextos de uso da palavra na LE. Em um exemplo do corpus, “... und ich habe viele mehr Dinge zu machen, die sie mir gegeben hat" - Inf. 2, Grupo A, Atividade D - ("e eu tenho muitas mais coisas para fazer que ela me deu"), no sentido de "delegou", “designou”, "atribuiu";

c) Não-distinção gramatical na LM em relação à LE: "o aluno comete um erro porque uma dada distinção gramatical existe [em LE], mas não em sua língua materna" (p. 68), como é o caso das declinações do alemão;

d) Uso de palavras portuguesas em sentenças de LE ("als Jung, er war ein ‘jagunço”) - Inf. 5, Grupo A, Atividade D.

e) Foreignizing: emprego de formas estrangeiradas ("inglesar" - ou, no nosso caso, "germanizar" - as palavras do português) - por exemplo, criar verbos em alemão, supostamente cognatos ou de origem latina, com a terminação -ieren, quando estes não existem ou não são usuais nessa língua;

f) Tradução literal ("wenn ich in Deutshland war" - Inf. 6, Grupo A, Atividade D) emprego da conjunção "wenn", em vez de "als", devido à sua tradução como "quando"; 
g) Transferência de estrutura (apoio na estrutura sintática da LM), como no caso já mencionado da generalização do "que" 90 .

Na sequência, Figueiredo, F. (2004) refere-se aos erros intralinguais, que "não refletem a influência da língua materna do indivíduo” (p. 76). Segundo o autor,

Esses erros compreendem "os desenvolvimentais” (Dulay, Burt e Krashen, 1982), que são semelhantes aos produzidos por crianças que adquirem a língua-alvo como L1, assim como "os erros únicos" (Dulay e Burt, 1974), que são produzidos unicamente por aprendizes de L2, sem, contudo, refletirem a influência da língua materna. (FIGUEIREDO, F., 2004, p. 77 - itálico do autor) ${ }^{91}$

Subdividem-se em:

a) Erros desenvolvimentais, a saber, a omissão ou adição de elementos na sentença, generalização - "uso de um marcador regular em lugar de um irregular" (p. 79), como no exemplo "gegeht" (não presente nos registros), em vez de "gegangen" -, formas alternadas de membros de uma mesma classe (p. ex., a indistinção entre as formas assumidas pelos relativos declinados) e ordem indevida de palavras. Contabilizam-se, ainda, a invenção de palavras ("word coinage"), a confusão entre termos lexicais semelhantes (os diferentes relativos), erros causados pela nãorelação grafema/fonema na $\mathrm{LE}$;

b) Erros únicos: "resultantes de hipóteses em relação à língua-alvo" (p. 84), não gerados pela influência da LM do aprendiz e não cometidos por crianças que aprendem essa LE como sua LM. Esses erros podem ser causados por adição,

\footnotetext{
${ }^{90}$ A respeito da interferência da LM, Kleppin (1998) nos lembra da teoria de aquisição contrastiva, de autores como Lado e Fries, que postulavam a possibilidade de se prever os erros dos alunos a partir de uma comparação sistemática da LM e da língua-alvo. Segundo essa perspectiva, haveria maior possibilidade de surgimento de erros nos casos em que elementos e regras das duas línguas diferissem. Entretanto, a autora menciona o caso de alunos chineses de um curso de ALE que declararam não ter dificuldades com estruturas do alemão ausentes no chinês, como as flexões e conjugações. Desse modo, Kleppin nos mostra que persistem dúvidas quanto aos postulados da teoria de aquisição contrastiva.

${ }^{91}$ As referências do autor nesse trecho são DULAY, H.; BURT, M.; KRASHEN, S. Language two. Nova York: Oxford University Press, 1982 e DULAY, H. C.; BURT, M. K. "You can't learn without goofing: an analysis of children's second language 'errors'”. In: RICHARDS, J. (Org.). Error analysis; perspectives on second language acquisition. Londres: Longman, 1974. p. 95-123.
} 
omissão, formas alternadas e podem consistir numa aglomeração ${ }^{92}$ de palavras que nada signifique.

O terceiro tipo de erros, os ambíguos, "podem ser considerados resultantes da influência da língua portuguesa (interlinguais) ou semelhantes aos cometidos por crianças que adquirem [a LE] como L1 (desenvolvimentais)". Podem ser originados por adição, omissão, "posicionamento indevido dos advérbios e locuções adverbiais" (p. 88) e formas alternadas.

Por fim, surgem os erros induzidos, que "não resulta[m] nem da interferência da língua materna, nem do processo evolutivo de aprendizagem de L2, mas sim da forma inadequada de se ensinar a língua-alvo" (p. 96).

Considerando a questão da comunicação e da compreensibilidade da produção dos estudantes, Figueiredo, F. (2004) classifica os erros entre aqueles que não afetam a comunicação, aqueles que "causam uma certa irritação" (p. 105), exigindo que o ouvinte faça um certo esforço para entender a mensagem, e erros que definitivamente impedem a comunicação. A questão da compreensibilidade é de suma importância no atual contexto e nas concepções contemporâneas de ensino-aprendizagem de línguas, com a chamada competência comunicativa sobrepujando-se à competência gramatical e, assim, com a compreensibilidade (e a fluência, cf. BETTERMANN et al., 2005) antepondo-se à gramaticalidade. Observe-se o que nos diz Schäfer (2013, p. 193-194) a respeito, remetendo-nos às bases da abordagem comunicativa e à virada comunicativa ${ }^{93}$ dos anos setenta:

\begin{abstract}
Nos anos 70, surge a abordagem comunicativa, até hoje muito difundida no ensino de línguas estrangeiras. Ela é responsável por uma "virada pragmática" no ensino de línguas estrangeiras. A língua não é mais encarada como um sistema formal, mas sim, como instrumento da ação humana (cf. NEUNER \& HUNFELD 1993: 88). A gramática passa a ocupar um papel secundário e servil na aula de LE: ela deve servir sempre às intenções e aos interesses comunicativos do aprendiz e ser apresentada a partir de um contexto próximo da realidade. Agora, o objetivo principal do ensino é desenvolver as habilidades (compreensão oral, fala, leitura e escrita) do aprendiz, para que o mesmo seja capaz de se comunicar na língua-alvo.
\end{abstract}

\footnotetext{
${ }^{92}$ Serão consideradas aglomerações as sequências de palavras que não exprimem sentido depreensível e também frases cujo sentido se apreende parcialmente, mas não pode ser depreendido de forma precisa, a exemplo de "eu falo sempre com minha médica a qual eu tenho dor de cabeça".

${ }^{93}$ Em Ming (2012), ofereço um panorama do papel atribuído à gramática (e a evolução da questão "ensiná-la ou não?", e como) durante a prevalência dos distintos métodos e abordagens na história do ensino de línguas. Essa comparação não será abordada diretamente neste trabalho, uma vez que essas informações e retomadas históricas não teriam como ser recuperadas durante a análise dos dados, fugindo, assim, do escopo imediato da presente dissertação.
} 
A autora prossegue, referindo-se ao QECR:

Segundo o Quadro Europeu Comum de Referência para Línguas, o ensino formal de línguas estrangeiras na atualidade deve visar ao desenvolvimento da competência comunicativa do aprendiz, para que este seja capaz de interagir em realidades cada vez mais plurilíngues. Sob essa perspectiva, a competência comunicativa divide-se em três subcompetências (linguística, sociolinguística e pragmática), as quais tornam a se decompor em várias outras. A competência gramatical, enquanto subdivisão da competência linguística, é definida pelo documento da seguinte forma:

A competência gramatical pode ser definida como o conhecimento dos recursos gramaticais da língua e a capacidade para os utilizar. Formalmente, a gramática de uma língua pode ser entendida como conjunto de princípios que regem a combinação de elementos em sequências significativas marcadas e definidas (as frases) [...] A competência gramatical é a capacidade para compreender e expressar significado, através da produção e do reconhecimento de frases e expressões bem construídas segundo estes princípios (ao contrário da sua memorização e reprodução) (CONSELHO DA EUROPA 2001: 161). [sic $]^{94}$

Chama a atenção, neste momento, a completa atualidade das considerações a respeito do ensino de gramática elaboradas por Jovanovic (1986) há quase três décadas. O autor nos lembra não apenas da necessidade de que se ensine a gramática não como um fim em sim mesma, mas sim a partir de uma perspectiva funcional, senão também "como um conjunto de regras capaz de permitir ao aluno generalizações, e a reutilização em novos contextos" (op. cit., p. 145). O professor prossegue, salientando que "o conceito confuso de que ensinar determinada língua equivale a ensinar a sua gramática - e tão somente esta - parece fora de cogitação" (p. 146). Assim, "a língua a ser ensinada (e aprendida) deve ser encarada como um

\footnotetext{
${ }^{94}$ Esses pressupostos vão de encontro, portanto, ao que Widdowson (1991, p. 32, apud SANTOS, E., 2001, p. 88) denominava uma concepção formalista de ensino, na qual "um pressuposto freqüente entre professores de línguas parece ser [...] o de que a tarefa essencial é a de ensinar uma seleção de palavras e estruturas, ou seja, elementos da forma, e que isso por si só atenderá as necessidades comunicativas qualquer que seja a área de uso relevante para um estudante num estágio posterior" [sic]. Santos, E. (2001) também nos lembra da tradição de se ensinar aos alunos frases prontas como "the book is on the table" (exemplo meu), de forma completamente desligada de necessidades e contextos comunicativos. E logo afirma (p. 91-92): "Fazer uso da língua requer múltiplas formas de conhecimentos (normas sobre quando dizer o quê e para quem) e o que pode ser chamado de controle (Bialystok \& Smith, 1985, p. 101-107) ou habilidade de uso (Widdowson, 1989, p. 128-137). Outra referência importante a Widdowson que Santos, E. (2001) faz é aquela que se refere à distinção do autor entre regras linguísticas de referência e de expressão: "Quando a atenção do aprendiz está direcionada à forma, como quando ele está treinando ou fazendo outro tipo de exercícios lingüísticos, então ele se voltará para as formaspadrão que lhe foram ensinadas e executá-las de acordo com as regras de referência de sua interlíngua. Mas quando ele está envolvido em qualquer tipo de atividade comunicativa, sua atenção está voltada para o uso efetivo e sua realização será de acordo com as regras de expressão" [sic]. (WIDDOSWON, 1975, p. 14-15, apud SANTOS E., 2001, p. 107). Referências do autor: WIDDOWSON, H. G. The significance of simplification. In: CORDER, P.; ROULET. E. Theoretical colloquy in Applied Linguistics, 1975. WIDDOWSON, H. G. Knowledge of language and ability for use. Applied Linguistics, 10 (2), 1989. WIDDOWSON, W. G. Aspects of language teaching. Oxford: Oxford University Press, 1990. BIALYSTOK, E.; SMITH, M. S. Interlanguage is not a state of mind: an evaluation of the construct for second-language acquisition. Applied Linguistics, 6 (2), 1985.
} 
instrumento de comunicação"95 (p. 148). O autor prossegue, retornando ao aspecto contexto, desta vez aquele necessariamente implicado no ensino-aprendizagem do saber gramatical: "sem a contextualização, dificilmente o aluno poderia aprender o uso apropriado e correto das regras sintáxico semânticas" (p. 150). Assim, o contexto surge, nas reflexões de Jovanovic, tanto como o ponto de partida para o ensino-aprendizagem de gramática (a contexualização necessária dos insumos) quanto como um objetivo do desenvolvimento da competência gramatical, a partir do momento em que se espera que o aluno possa empregar a gramática também contextualizadamente, a saber, na construção de novos contextos e sentidos. Um outro trecho do texto de Jovanovic (1986, p. 153) desencadeia a necessidade de importantes esclarecimentos quanto à própria natureza deste trabalho. Veja-se:

\begin{abstract}
Segundo a nossa perspectiva a gramática - entendida como uma codificação de conceitos relacionais entre os signos do código linguístico - desempenha um papel parcial no processo de aprendizagem da gramática da L2, não poderá ocorrer por intermédio de simples exercícios estruturais em que se ponha em relevo a aplicação de uma determinada regra gramatical da L2 em questão.
\end{abstract}

Em outro escrito, o autor lança uma relevante pergunta a respeito do ensino de estruturas morfossintáticas de uma língua e sua contribuição para que o aprendiz adquira competência comunicativa na LE:

Encarados os fatos à luz dos estudos lingüísticos e psicolingüísticos mais recentes, uma das questões básicas a serem argüidas diz respeito ao seguinte: uma simples apresentação e/ou descrição das regras morfossintáticas de uma língua qualquer capacita o estudante a tornar-se um falante dessa mesma língua? [...] parece óbvio que a enunciação de regras morfossintáticas, subordinadas a uma perspectiva "filosófica", em momento algum podia capacitar, quem quer que fosse, a tornar-se falante da língua estrangeira assim ensinada. (JOVANOVIC, 1992, p. 175)

Ora, neste ponto faz-se necessário assumir um posicionamento quanto a essas asserções, bem como interrelacioná-las com o tipo de experimento e análise de dados que se leva a cabo nesta dissertação. Embora concorde com as idéias de Jovanovic, e se possa afirmar que as instituições de ensino onde se deu a coleta de dados e os LDs adotados também tenham como base esses postulados e noções acerca dos gestos de ensinar e aprender gramática, para esta pesquisa concentrei-me no recorte do momento de curso - um entre muitos outros, e certamente não o mais importante ou único a ser destacado - em que a regra gramatical (a ser utilizada a posteriori pelo aprendiz como ferramenta e instrumento extensível a múltiplos contextos comunicativos) é explicitamente ensinada e treinada

\footnotetext{
${ }^{95}$ Negrito do autor citado.
} 
mediante a aplicação de exercícios focados também na estrutura. Esse tipo de treino de estrutura, ao lado de atividades sumamente comunicativas, onde se encara funcionalmente o conhecimento gramatical e o conhecimento linguístico em geral, em contra daquilo a que se refere Santos, E. (2001) como sendo uma abordagem gramaticalista, está presente em todos os LDs arrolados no apêndice (adotados pelas escolas de idiomas que oferecem cursos de ALE no estado de São Paulo).

Há duas questões a se considerar neste momento. Primeiramente, as observações de Nascimento (2007) acerca da prática de ensino pós-comunicativa de LE na contemporaneidade, em tempos denominados por alguns autores (BORGES, 2010; PRABHU, 1987 y 1990; PICA, 2000; KUMARAVADIVELU, 2006, 2006a; SILVA, G., 2008), era (ou condição) pós-método:

Hoje, no que já é chamada por vários de era do pós-comunicativo, as abordagens, métodos e metodologias tendem a ser mais ecléticos. Aos poucos, o furor comunicativo foi dando lugar a uma reflexão mais madura, em que se percebeu a necessidade de equilíbrio entre o desenvolvimento das quatro habilidades. Não se joga fora ou se condena o que veio anteriormente; busca-se aproveitar aquilo que as diversas concepções e aplicações trouxeram de mais interessante e útil. As novidades não são tomadas radical ou literalmente; como é de praxe acontecer, tenta-se, em geral, buscar um equilíbrio (NASCIMENTO, 2007, p. 9-10).

Assim, nos tempos atuais, exercícios de treino de estruturas, vária vez associados à milenar abordagem de gramática-e-tradução ${ }^{96}$, também têm seu lugar garantido e sua importância assegurada no seio de cursos contemporâneos de LE, embora, como recém se afirmou, partindo de um contexto e rumando à produção de vários contextos em ensejos comunicativos reais.

Neste ponto, interessa reproduzir as palavras de Vitullo (2011, p. 147) a respeito do ensino de gramática, elaboradas ao final de sua pesquisa de doutorado, na qual investigou "a concepção, a importância e o enfoque conferidos à gramática no desenvolvimento do ensino e aprendizagem", por meio de "questionários aplicados a professores e alunos bem como de observação de aulas" (op. cit., p. 9):

Indiscutivelmente, é preciso recorrer à norma gramatical na didática das línguas, uma vez que as regras de construção sintática e a própria nomenclatura de

\footnotetext{
${ }^{96}$ Alguns autores falam, tradicionalmente, em "método gramática-e-tradução", mas, neste trabalho, concorda-se com a designação "abordagem", empregada por Leffa (1988) e Jovanovic (1992). Sobre mais a respeito da distinção entre métodos e abordagens, veja-se Leffa (1988).
} 
classificação dos fenômenos linguísticos estabelecem formas confiáveis e seguras de utilização de uma língua, mostrando seu funcionamento básico, sua estrutura fundamental. [...] Com relação aos professores, cabe a eles primeiramente conhecer a gramática para fazer um bom uso dela e mostrar [as] diferenças de situações e domínios para melhor definir o que seja gramática e qual sua verdadeira função, para a partir daí mostrar que a gramática pode ser de grande auxílio na compreensão e expressão em uma língua, ou seja, para a aprendizagem dessa língua. Não acreditamos tampouco que a demanda por parte dos alunos para que se ensine a gramática e o reconhecimento de que o saber gramatical é necessário, defendido também pelos professores, como comprovaram as pesquisas, sejam apenas um hábito criado pelas escolas que acreditam que se ensina LM ou LE por meio da gramática. Acreditamos, sim, que essa demanda provém da comprovação da necessidade de conhecimento gramatical para um aprendizado realmente satisfatório. Ora, se tanto os alunos quanto os professores defendem o ensino da gramática, não deve ser sem razão. (VITULLO, 2011, p. 147) ${ }^{97}$

Em outro trabalho de doutorado do mesmo ano, Gomes chegou às seguintes conclusões após seus experimentos:

concernente ao papel que a gramática desempenha no curso da aprendizagem, constatou-se que ela se revela necessária a fim de corroborar a interiorização da gramática da língua e, assim, proporcionar a produção de enunciados pertinentes ao francês. Diante dessa constatação, a comunicação, de modo compreensível, na língua-alvo pressupõe o domínio das regras gramaticais e no caso da ausência, ou da ineficiência, desse domínio, ela pode sofrer eventuais irregularidades morfológicas e sintáticas. Tal qualidade, irregular, afeta a formulação de uma sequência lógica de frases, prejudicando, consequentemente, a mensagem veiculada pela língua (que se encontra em processo de aprendizagem). (GOMES, 2011, p. 171)

Também considero relevante lembrar, em segundo lugar, o fato de que, se focarmos apenas a compreensibilidade, a comunicação e as funções comunicativas da linguagem ao tratarmos do elemento gramatical em aula, o ensino e a descrição de estruturas da língua-meta se faz quase prescindível, ao menos como ainda é entendido hoje em dia. Durante a análise

\footnotetext{
${ }^{97}$ Desenvolvi um trabalho sobre crenças e concepções de alunos acerca do ensino-aprendizagem de gramática (PRADO; MING, 2011) que nos levou a perceber que o alunado considera a gramática uma ferramenta útil para o desenvolvimento da comunicação, entre outros fatores. Assim, como afirma Vigner (2004, apud GOMES, 2011, p. 14), "todos os aprendizes têm necessidade de interiorizar as regras da gramática de uma língua se eles querem produzir espontaneamente enunciados pertinentes nessa língua". E, nas palavras de Possenti (apud GOMES, 2011, p. 14), "quem diz e entende frases faz isso porque tem um domínio da estrutura da língua". A despeito destas citações, repita-se, a gramática deve ser ensinada contextualizadamente e as estruturas não devem ser exploradas de maneira excessiva ou de modo a assumir a linha de frente dos cursos (comunicativos) de LE. Também não podemos esquecer que, para alguns autores, o conhecimento declarativo nem sempre se transforma em fluência (ver item 1.2.3.1). É ainda relevante lembrar que, em certas fases do ensinoaprendizagem, estruturas são ensinadas como chunks, sem que se lance mão de metalinguagem para explicá-las aos alunos, como no caso em que aprendentes iniciantes de alemão travam contato com a expressão "Wie geht's (dir/Ihnen)?" sem que lhes seja explicitado que "dir" e "Ihnen" são pronomes pessoais no dativo, que em uma pergunta iniciada por interrogativo-q (W-Frage) o verbo permanece na segunda posição sintática da frase, que o sujeito-nominativo da oração é "es" etc. Nos LDs com que trabalham os professores-voluntários, essa explicação é oferecida, entretanto, em uma ocasião futura.
} 
dos dados, na parte 3 deste trabalho, veremos que o emprego gramaticalmente equivocado de um pronome relativo alemão ("der" por "den", "den" por "dem", "das" por "die"), de forma geral, não afeta a compreensão do enunciado, assim como, por analogia, se pode afirmar que falantes minimamente proficientes em português, nativos ou não, entende(ria)m construções como "a menina o qual eu vi" verbo ao final da oração relativa. A ocorrência desse tipo de erro, se não associada a outros problemas de origem semântico-pragmática, não afeta de forma decisiva a semântica e funcionalidade imediata do enunciado. Apesar disso, creio que nenhum professor concordaria com ensinar aos seus alunos, por esse motivo, que poderiam inserir no início da oração relativa qualquer relativo-d, indiscriminadamente, e colocar o verbo em posição a escolher a gosto, uma vez que a possibilidade de que seu enunciado fosse compreendido continuaria sendo relevante. Sabemos que, na vida em sociedade, o domínio de (também) variantes linguísticas de prestígio angaria ao indivíduo inclusão, promoção e ascenção sociais. Permitelhe "ocupar posições na sociedade" e de modo que se garanta "a produção de textos adequados às situações" (NEVES, 2001, p. 231). E as situações, no convívio social, nas quais o falante se beneficia se souber mobilizar as regras da norma culta, são numerosas, e muitos desejam nelas inserir-se. E isso necessita treino. Para manter como exemplo o objeto de estudo desta pesquisa, algo inicialmente simples (apesar de sua dificuldade para aprendizes brasileiros) como (re)conhecer as formas, funções e lugares dos relativos-d nos enunciados e discursos alemães facilita o acesso do aprendiz ao meio acadêmico alemão, a empregos em que necessite comunicar-se com clientes e parceiros comerciais, oralmente e, principalmente, por escrito, e todas as situações nas quais seja esperado que demonstre deter certo grau de instrução formal, letramento avançado e escolaridade. Falar fluentemente errado é, sem dúvida, uma possibilidade que satisfaz a muitos (incluídos nesse montante uma multiplicidade de ex-alunos que tive), mas ao aluno deve ser facultada a possibilidade, ou garantido o direito, de também conhecer as formas linguísticas valorizadas e prestigiadas socialmente. Também é importante lembrar, algo que já se afirmou neste trabalho, que o modelo linguístico apresentado aos informantes da pesquisa, apesar do grande número de falares regionais e socioletos encontrados nas sociedades de língua alemã, não representa um falar pedante, extremamente erudito ou distante da realidade linguístico-cultural do alemão médio - ao contrário, por exemplo, das relativas preposicionadas do e no português brasileiro, forma rara na comunicação oral (e até em vários exemplos de comunicação informal e até social escritas)

\footnotetext{
${ }^{98}$ É evidente que o nível de irritação possível vai depender da formulação do falante, inserida em seu contexto, do canal de comunicação, da recepção do interlocutor específico, e não pode ser prevista de forma generalizada de antemão, como uma regra universal.
} 
em nossa língua. Por fim, relembro que a tipologia de exercícios de Neuner et al. (1981), adotada pelos professores-informantes desta pesquisa, propõe a progressão de exercícios mais controlados aos mais livres, nos quais o aprendiz emprega a estrutura gramatical na construção de contextos e comunicação. Assim, em atividades propostas dessa maneira, o aluno passa de exercícios de fixação (Festigung) para os de aplicação (Anwendung). Vale lembrar, ainda, que nesta pesquisa se foca no desempenho dos estudantes em exercícios escritos aplicados após a tomada de contato com a nova estrutura. Em uma situação normal, em curso, o professor aplicaria atividades de prática oral de tipos diversos, incluindo, possivelmente, a simulação de situações comunicativas. Aqui vale lembrar as palavras de Percegona (2005, p. 94), segundo quem a falta de foco na forma, quando se investe apenas na comunicação, poderia levar à fossilização de erros:

\begin{abstract}
A abordagem comunicativa, por outro lado, enfatiza a transmissão de idéias em contextos reais de comunicação. Nela os alunos são encorajados a desenvolver estratégias de comunicação sem se preocuparem com a correção lingüística. A unidade básica da língua que requer atenção é o ato comunicativo, ao invés da frase, ou seja, a competência comunicativa passa ser o objetivo em vez da construção de conhecimento gramatical ou da estocagem de formas memorizadas. Não há dúvidas de que é importante, no ensino de línguas, encorajar os alunos a transmitir seus pensamentos em situações reais; entretanto, este tipo de método, baseado em processos de comunicação, pode até levá-los a alguma fluência verbal, mas, de acordo com Lightbown e Spada (1993, p.80), "muita 'liberdade' sem correção e instrução explícita pode levar a uma fossilização precoce". ${ }^{99}$
\end{abstract}

Levando tudo isso em conta, na análise da produção dos informantes, na parte terceira deste trabalho, serão sobrepostas duas classificações, i.e., na análise dos erros será considerada sua tipologia geral e também se afetam ou não a comunicação. Isso significa que serão dedicados foco na forma e foco na comunicação (e no significado). Quanto a essa dicotomia, como resume Cavalari (2008, p. 51):

Doughty \& Williams (op.cit.) e Williams (op.cit.) redefinem a expressão foco na forma, uma vez que não se referem ao tipo de ensino de língua em que o princípio de organização do conteúdo é o acúmulo de elementos lingüísticos isolados (focus on formS), mas sim a um tipo de ensino que requer o engajamento prévio em atividades focadas no significado, a fim de que a atenção aos aspectos lingüísticos possa ser bem sucedida (focus on form). Ainda que o foco esteja, brevemente ou simultaneamente, em aspectos do código lingüístico (como a pronúncia, a definição de uma palavra, formas verbais etc) é crucial, nessa nova definição de foco na forma (FonF), que o foco principal do ensino seja o processamento do significado

\footnotetext{
${ }^{99}$ A autora cita LIGHTBOWN, P. M.; SPADA, N.. How languages are learned. Oxford: Oxford University Press, 1993.
} 
num ato de comunicação. Portanto, o aprendiz deve perceber e então processar a estrutura gramatical enfocada por meio de insumo puramente comunicativo. $[\mathrm{sic}]^{100}$

Assim, proceder-se-á, na terceira parte deste trabalho, à análise da produção linguística dos aprendizes focando na correção gramatical de suas sentenças e também no êxito ou não em suas tentativas de gerar significação na LE.

100 A autora faz referência a DOUGHTY, C.; WILLIAMS, J. (Orgs.). Focus on form in classrom second language acquisition. Cambridge: Cambridge University Press, 1998 e a WILLIAMS, J. Focus on form: research and its application. Revista Brasileira de Linguística Aplicada, v.1, n.1, 2001, p.31-52. 


\subsection{Teorias de aprendizagem, aquisição e processamento}

\subsubsection{Considerações introdutórias}

Uma vez tecidas as considerações necessárias e introdutórias acerca da questão gramatical, pretendem-se sublinhar, neste item, os principais componentes das teorias de aquisição e processamento de informação necessários para fundamentar meus experimentos acerca do ensino-aprendizagem de gramática e o desenvolvimento do presente texto.

Para tal vale lembrar que, aproximadamente na década de cinquenta, o ramo dos estudos que interrelacionam a linguagem e a psique humana passou a recair sob o escopo da Psicolinguística. Como nos lembra Peterfalvi (1970), essa disciplina que, como a própria denominação indica, estabelece uma ponte entre a Psicologia e a Linguística, embora se pretenda independente de ambas, é fruto de criação intencional e resultado de uma reunião de pensadores, celebrada em 1951 nos Estados Unidos. Em sua infância, a "nova" área do conhecimento teria recebido insumos da Linguística Estrutural, da Teoria da Informação e, muito especialmente, do pensamento chomskiano, a partir da publicação da obra seminal Syntactic Structures em 1957.

Ao campo de interesses dessa disciplina, em sua acepção atual, pertenceriam discussões tais como as que se dedicam:

1. à problemática dos processos que levam o ser humano ao domínio da linguagem;

2. aos saberes do falante nativo acerca de sua língua materna;

3. ao funcionamento dos processos do falar e do compreender, e

4. aos problemas ou erros que incidem durante a produção de linguagem.

$\left(\right.$ HARDEN, 2006) ${ }^{101}$

Mais recentemente, desde o período pós-guerra, circunstâncias de cunho econômico,

\footnotetext{
${ }^{101}$ O presente trabalho contempla, de modo geral, as questões 1 e 4, uma vez que se abordará o processo de ensino-aprendizagem e se procederá à análise da produção linguística escrita dos aprendizes, à sua interpretação e à localização de erros e acertos de acordo com a perspectiva teórica e analítica esboçada no item anterior.
} 
sócio-político e transcultural passaram a ditar a necessidade de que um maior número de pessoas se debruçasse sobre a língua do outro como objeto de estudos. Métodos e abordagens de ensino e aprendizagem emergiram rapidamente, tendo como base desenvolvimentos e descobertas recentes da Linguística, da Psicologia, da Pedagogia e de outras disciplinas irmanadas. Concomitantemente, um braço da Psicolinguística passou a receber especial atenção por parte de estudiosos interessados em desvendar os processos atravessados pelos aprendizes de línguas, maternas ou não. Trata-se do interesse nas atividades mentais que acompanham os caminhos de apropriação da língua alheia. Entre as principais teorias de grande influência no seio dos estudos desse campo destacam-se - em apresentação não exaustiva dessas correntes teóricas e seus expoentes - a Análise Contrastiva, o Behaviorismo (e a teoria comportamental do aprendizado linguístico) de Skinner, o Inatismo de Chomsky, o Construtivismo de Piaget, a Análise de Erros de Corder e a Interlíngua de Selinker. Merecem também menção os estudos da ordem de aquisição de morfemas, de Brown, Dulay \& Burt, o Modelo do Monitor e as cinco hipóteses de Krashen, bem como sua célebre distinção entre aquisição e aprendizagem, a hipótese do período crítico de Lenneberg, o modelo da aculturação de Schumann, as teorias acerca do processamento de informação e do papel da(s) memória(s) no ensino-aprendizagem e, por fim, a Teoria da Processabilidade, de Pienemann.

\subsubsection{Teorias de aquisição e aprendizagem}

Dada a natureza deste trabalho, pretendo dedicar-me mais acuradamente a tratar dessas últimas duas dimensões teóricas, cujo conhecimento faz-se fundamental para abordar, mais adiante, as questões advindas da problemática do ensino-aprendizagem de gramática de LE a partir das abordagens sintética e analítica. Entretanto, na tabela a seguir, oferece-se uma visão geral dos principais conceitos que definiram as supramencionadas correntes teóricas, de modo a sumarizar discursos que, se muitas vezes não perduraram até os dias atuais, exerceram influência no pensamento de autores cujas obras são de relevante alcance no exercício da pesquisa em nossa área de atuação. 
Tabela 3 - Principais teorias de aquisição e de aprendizagem de línguas estrangeiras

\begin{tabular}{|c|c|c|}
\hline $\begin{array}{c}\text { CORRENTE } \\
\text { TEÓRICA }\end{array}$ & $\begin{array}{c}\text { PRINCIPAIS } \\
\text { AUTORES }\end{array}$ & CONCEITOS CENTRAIS \\
\hline $\begin{array}{l}\text { Behaviorismo } \\
\left(\sim 1957^{102}\right)\end{array}$ & Skinner & $\begin{array}{l}\text { - Aprendizado de língua não diferiria de outras formas de aprendizagem; } \\
\text { - Estímulo e resposta; } \\
\text { - Automatização de respostas desejáveis e eliminação de respostas inadequadas; (MITCHELL \& MYLES, } \\
\text { 2004) } \\
\text { - Criança tida ao início do processo de aprendizagem como uma "tabula rasa", mantendo-se com nenhuma } \\
\text { participação ativa na construção do próprio conhecimento; } \\
\text { - Pensamentos/mente do indivíduo desconsiderados nas pesquisas - "caixa preta" - prioridade a elementos } \\
\text { efetivamente observáveis. (JOHNSON, 2004). }\end{array}$ \\
\hline $\begin{array}{l}\text { Análise } \\
\text { Contrastiva }\end{array}$ & $\begin{array}{l}\text { Charles Fries } \\
\text { Robert Lado }\end{array}$ & $\begin{array}{l}\text { - Influenciada pelo Behaviorismo; } \\
\text { - Descrição do sistema linguístico dos aprendizes e do estrangeiro a ser estudado para prever e evitar } \\
\text { transferências negativas e erros; } \\
\text { - Estímulo a transferências positivas. }\end{array}$ \\
\hline Inatismo $(\sim 1957)$ & $\begin{array}{l}\text { Noam } \\
\text { Chomsky }\end{array}$ & $\begin{array}{l}\text { - A linguagem humana é própria da nossa espécie, inata e biogeneticamente determinada, de natureza } \\
\text { maturacional, independente de estimulação externa (MELO, 2005), fisicamente representada no cérebro } \\
\text { (CHOMSKY, 2002), e adquire-se por meio do chamado 'dispositivo de aquisição da linguagem' (DAL); } \\
\text { - Crianças internalizam as regras do sistema linguístico até poderem formular um número infinito de } \\
\text { sentenças inéditas com base em um número finito de regras e signos em dada língua (DEESE, 1970); } \\
\text { - O falante nativo desenvolve uma intuição natural para o julgamento da gramaticalidade dos enunciados } \\
\text { construídos por outrem em sua língua. }\end{array}$ \\
\hline
\end{tabular}

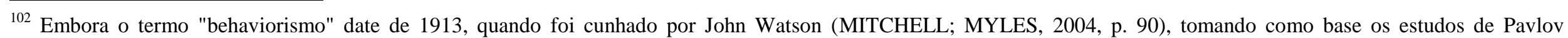
(FINGER, 2008).

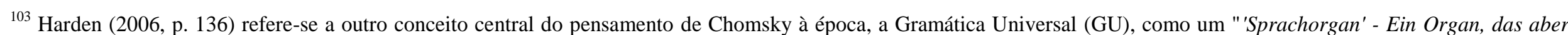

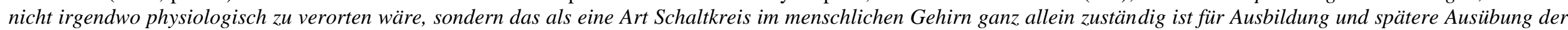

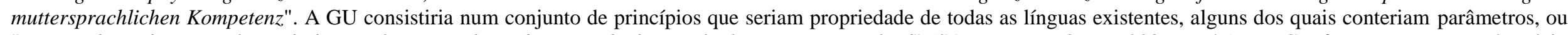
"points where there is a limited choice of settings depending on which specific language is involved" (SAVILLE-TROIKE, 2006, p. 47). Da GU fazem parte, segundo Klein (1984), a totalidade do vocabulário, da morfologia, da sintaxe e grande parte da fonologia. „What is acquired on L1 acquisition is not UG itself; UG is already present at birth as

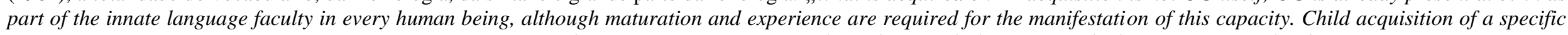

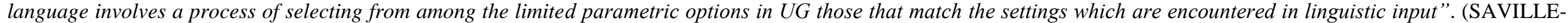




\begin{tabular}{|c|c|c|}
\hline Construtivismo & Jean Piaget & $\begin{array}{l}\text { - Estágios do desenvolvimento cognitivo próprios da espécie e biogeneticamente determinados (MELO, } \\
\text { 2005); } \\
\text { - Interação entre o indivíduo e seu objeto de aprendizagem; o sujeito é construtor do próprio conhecimento } \\
\text { - dependente, porém, do contato com o outro; } \\
\text { - Períodos de maturação (sensório motor, pré-operatório, operatório-concreto e operatório-formal); } \\
\text { - Assimilação e acomodação } 104 ; \\
\text { - Construção do conhecimento a partir da formulação e do teste de hipóteses, tentativas e erros; } \\
\text { - Conhecimento não é inato e se constrói a partir da relação com os objetos da experiência e o entorno; } \\
\text { - Enfoque do papel da afetividade (sentimentos e tendências, entre elas a volição) no processo de } \\
\text { aprendizagem. }\end{array}$ \\
\hline $\begin{array}{l}\text { Análise de Erros } \\
(\sim 1967)\end{array}$ & Corder $^{105}$ & $\begin{array}{l}\text { - Resposta às limitações da posta em prática da Análise Contrastiva; } \\
\text { - Depósito de relevância na criatividade do aprendiz e em sua capacidade de manipular a língua-alvo no } \\
\text { processo de ensino-aprendizagem; } \\
\text { - Análise de erros na produção dos aprendizes para verificar a assimilação ou não dos conteúdos. }\end{array}$ \\
\hline Interlíngua (1972) & Selinker & $\begin{array}{l}\text { - Considera o sistema linguístico desenvolvido pelo aluno como um todo sistemático, dinâmico, flexível, } \\
\text { mutável; } \\
\text { - Esse sistema }{ }^{106} \text { é informado pela língua materna do aprendiz, pela língua alvo em direção à qual o aluno } \\
\text { marcha durante o aprendizado, bem como pelo entorno. }\end{array}$ \\
\hline
\end{tabular}

TROIKE, 2006, p. 49)

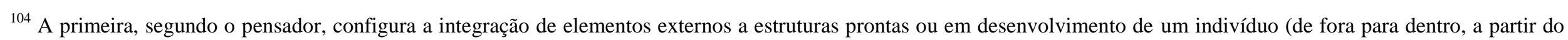
meio); a segunda, a adaptação de estruturas internas aos requisitos ou elementos de uma assimilação que se pretenda exitosa (PIAGET, 1977).

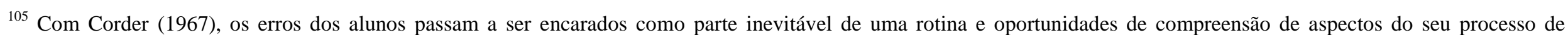

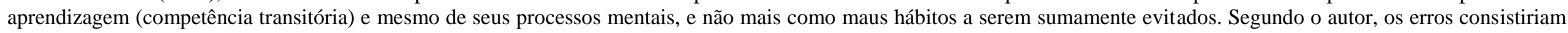

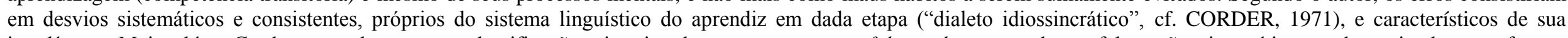
interlíngua. Mais além, Corder procedeu a uma classificação tripartite dos erros em erro, falta e lapso, sendo as faltas não sistemáticas e determinadas por fatores

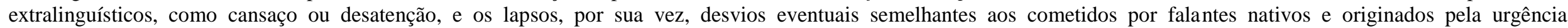

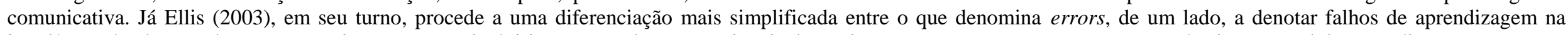
interlíngua do aluno e, de outro, mistakes, termo que incluiria os meros lapsos ocasionais de performance que não comprometem o conhecimento real do aprendiz.

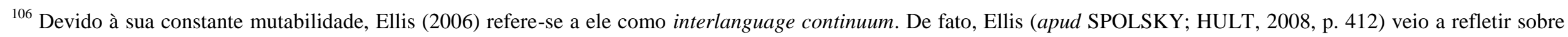
uma flexibilização do conceito de interlíngua encontrada na literatura ao recopilar nuances interpretativas do termo: 


\begin{tabular}{|c|c|c|}
\hline $\begin{array}{l}\text { Ordem de } \\
\text { Aquisição de } \\
\text { Morfemas ( 1973) }\end{array}$ & $\begin{array}{l}\text { Brown } \\
\text { Dulay \& Burt }\end{array}$ & $\begin{array}{l}\text { - Ordem natural, ou sequência universal do desenvolvimento da gramática de aprendizes de línguas não } \\
\text { maternas; } \\
\text { - Linguagem infantil como sistema organizado por regras internas, ainda que elas difiram das que regem a } \\
\text { fala adulta; } \\
\text { - Crianças formulam e comprovam regras e hipóteses; sua fala não é meramente imitativa, se desenvolve } \\
\text { seguindo uma capacidade própria e pré-programada de processamento, muito similar entre crianças da } \\
\text { mesma idade e parecida também entre falantes de línguas distintas. }\end{array}$ \\
\hline $\begin{array}{l}\text { Hipótese do } \\
\text { Período Crítico } \\
\text { (1967) }\end{array}$ & Lenneberg & $\begin{array}{l}\text { - Período relativamente breve, da infância à puberdade, dentro do qual se encerraria o processo de } \\
\text { aquisição da língua materna }{ }^{107} ; \\
\text { - Lateralização cerebral }{ }^{108} \text {; } \\
\text { - Nature-nurture-conflict, a polarização do inato versus o aprendido via interlocução; }\end{array}$ \\
\hline $\begin{array}{l}\text { Hipóteses de } \\
\text { Krashen }\end{array}$ & $\begin{array}{l}\text { Stephen } \\
\text { Krashen }\end{array}$ & $\begin{array}{l}\text { 1) Aquisição e aprendizagem (KRASHEN, 1981): } \\
\text { - Aquisição como processo natural e subconsciente de assimilação da linguagem, baseado em interações } \\
\text { que ocorrem em contextos comunicativos autênticos e práticos }{ }^{109} \text {; }\end{array}$ \\
\hline
\end{tabular}

The term has come to be used with different but related meanings (i) to refer to the series of interlocking systems which characterize acquisition, (ii) to refer to the system that is observed at a single stage of development ("an interlanguage"), and (iii) to refer to particular L1/L2 combinations (for example, L1 French/L2 English vs. L1 Japanese/L1 English).

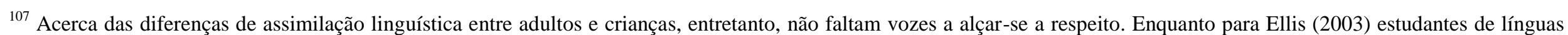

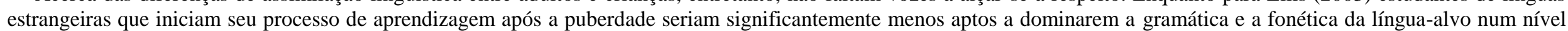

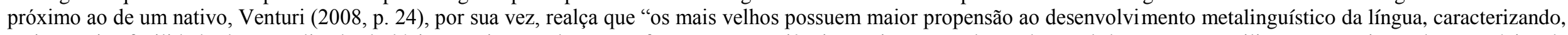
assim, maior facilidade de aprendizado de léxicos mais complexos e referentes a experiências mais vastas, de modo geral, bem como a utilização consciente de estratégias de aprendizagem. Tais estratégias diferem-se, portanto, daquelas adotadas pela criança quando aprende a primeira língua num contexto natural, espontâneo. O indivíduo adulto, em

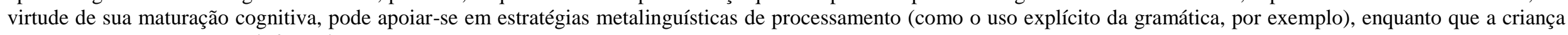
chega às generalizações por inferência".

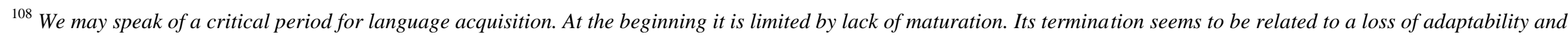
inability for re-organization in the brain, particularly with respect to the topographical extent of neuro-physiological processes... the limitations in man may well be connected

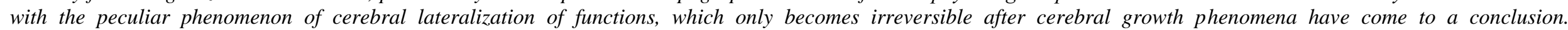
(LENNEBERG, 1967, p. 1797 apud FELIX, 1982, p. 241) 


\begin{tabular}{|c|c|c|}
\hline & & $\begin{array}{l}\text { - Aprendizagem como o estudo consciente da língua em sala de aula, com foco na forma e baseado no } \\
\text { domínio de regras }{ }^{110} 111 \text {; "Estudo formal não se transformará em assimilação" (KRASHEN, 1982, p. 83) }\end{array}$ \\
\hline $\begin{array}{l}\text { Hipóteses de } \\
\text { Krashen }\end{array}$ & $\begin{array}{l}\text { Stephen } \\
\text { Krashen }\end{array}$ & $\begin{array}{l}\text { 2) Monitor: } \\
\text { - O que foi aprendido (e não adquirido) teria um único uso ou função, a de um monitor ou editor que } \\
\text { permitiria que o aprendiz procedesse à autocorreção durante ou depois da enunciação - ou mesmo antes, } \\
\text { quando houver possibilidade de preparação antecipada do discurso; } \\
\text { - Competência adquirida seria responsável por desencadear a produção linguística e pela fluência } \\
\text { discursiva; } \\
\text { - Monitor over-users, sujeitos que tendem a monitorar altamente sua produção; } \\
\text { - Monitor under-users, privilegiam a fluência e a comunicação no lugar da forma e da correção; } \\
\text { 3) Ordem natural: } \\
\text { - Hipótese influenciada pelos Morpheme Studies; considera-se a possibilidade de previsão da sequência em }\end{array}$ \\
\hline
\end{tabular}

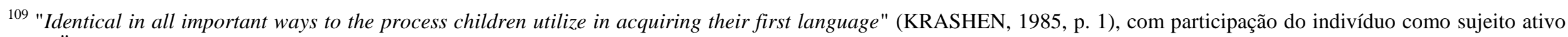
(SCHÜTZ, 2013) e envolvendo o dispositivo de aquisição da linguagem (SAVILLE-TROIKE, 2006).

110 "Immer nur durch einen 'Monitor', [...] eine Kontrollinstanz" (KLEIN, 1984, p. 39).

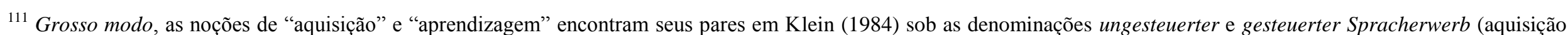

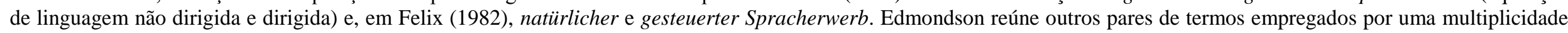

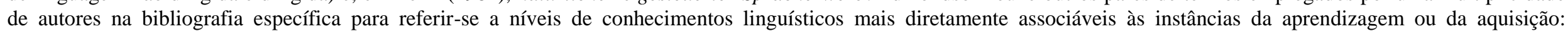
conhecimento "declarativo" versus "procedimental", "explícito" versus "implícito" e acesso "controlado" versus "automatizado" ao conhecimento:

Insgesamt kann gesagt werden, dass deklaratives Wissen das "Wissen, dass" ist, während prozedurelles Wissen eher das "Wissen, wie" bedeutet. Explizites Wissen kann bewusst abgerufen und eingesetzt werden: man weiß, dass man dieses Wissen besitzt und in der Lage ist, es zu artikulieren, d.h. darüber zu sprechen. Bei implizitem Wissen treffen diese Merkmale nicht zu: man zeigt nur durch sein Verhalten, dass ein solches implizites Wissen vorliegt. Daher ähnelt explizites Wissen inhaltlich einer auswendig gelernten textuellen Grammatik G2 während implizites grammatisches Wissen einer psychologischen Grammatik Gl entspricht. Ein kontrollierter Zugang zu sprachlichen Wissen ist der Gegenpol zu einem automatischen Zugang, d.h., ein kontrollierter Zugang ist langsamer, nimmt viel mehr kognitive Kraft und Energie in Anspruch und ist nicht mehr erfolgreich: man findet nicht immer das, wonach man sucht. Diese Charakterisierungen sind eher Andeutungen als Definitionen [...] (EDMONDSON, 2002, p. 57)

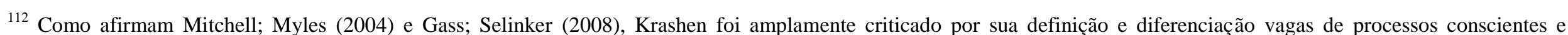

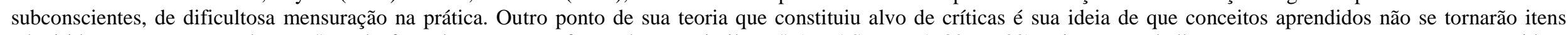
adquiridos ou, em suas palavras, "estudo formal não se transformará em assimilação" (KRASHEN, 1982, p. 83). Diversos trabalhos assumem a contramão nesse sentido e

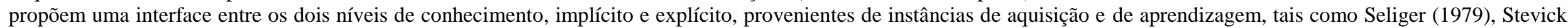
(1980) e Bialystok (1978, 1979 e 1981), cf. Raupach (2002). 


\begin{tabular}{|c|c|c|}
\hline $\begin{array}{l}\text { Hipóteses de } \\
\text { Krashen }\end{array}$ & $\begin{array}{l}\text { Stephen } \\
\text { Krashen }\end{array}$ & $\begin{array}{l}\text { que se adquirem as regras de uma língua, tendendo a aquisição de algumas a ocorrer previamente à de } \\
\text { outras; } \\
\text { 4) Input: } \\
\text { - A progressão de conteúdos linguísticos aos quais o estudante deveria ser exposto teria de corresponder a } \\
\text { uma justa medida, a um comprehensible input ou intake (um input parcialmente conhecido e } \\
\text { compreensível), não excedendo nem estando aquém de doses ideais de insumo novo; } \\
\text { - Se o nível de competência de um aprendiz, em dado momento, correspondesse a } i \text {, competiria ao } \\
\text { professor oferecer-lhe em aula } i+1 \text { (intake), o próximo passo numa sequência de desenvolvimento } \\
\text { linguístico } 113 \text {; } \\
\text { 5) Filtro afetivo: } \\
\text { - A receptividade/atitude do aprendiz diante da língua e da cultura às quais se está expondo determinaria a } \\
\text { assimilação ou não dos conteúdos }{ }^{114} \text {. }\end{array}$ \\
\hline $\begin{array}{l}\text { Modelo de } \\
\text { Aculturação } \\
(\sim 1978)\end{array}$ & Schumann & $\begin{array}{l}\text { - Pidginização e aprendizagem (ou aquisição não dirigida) de línguas não maternas consistem no mesmo } \\
\text { processo (KLEIN, 1984); } \\
\text { - A aculturação de aprendizes estrangeiros e sua aprendizagem da LE será mais exitosa dependendo de } \\
\text { quão próximos se sintam da comunidade que tem aquela língua como materna, i.e., o quão mais } \\
\text { identificados se sintam com tal comunidade, mais chances terão de aproximar-se linguisticamente dela; } \\
\text { - Quanto maior a distância entre aprendiz e comunidade, mais se assemelhará a produção linguística a um } \\
\text { pidgin. }\end{array}$ \\
\hline
\end{tabular}

\footnotetext{
${ }^{113} \mathrm{O}$ texto de Krashen, ainda que tão influente, não permite entrever, contudo, como exatamente se poderia definir o comprehensible input e determinar objetivamente os níveis $i$ e $i+1$.

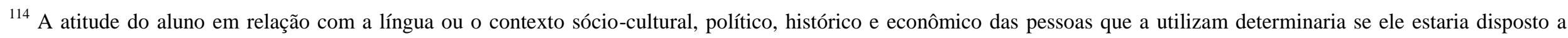
permitir a recepção do input, podendo vir a bloqueá-lo: "even if they understand the message, the input will not reach that part of the brain responsible for language acquisition, or the Language Acquisition Device" (KRASHEN, 1982, p. 31 apud MITCHELL; MYLES, 2004, p. 48). Para estes autores (2004, p. 48-9), todavia,
}

Krashen's Affective Filter remains vague and atheoretical. [...] [In general,] Krashen's main overall weakness was the presentation of what were just hypotheses that remained to be tested, as a comprehensible model that had empirical validity. He then used his hypotheses prematurely as a basis for drawing pedagogical implications. 


\title{
2.2.3 Teorias de Transição
}

Em oposição às chamadas property theories, dedicadas ao estudo da dimensão linguística dos processos de aquisição, as teorias de transição, por sua vez, ocupam-se do elemento "aprendizagem" envolvido nesse mesmo universo temático. Em outras palavras, integra o escopo dessas teorias a preocupação com a forma como se aprendem e adquirem línguas, embora essa instância específica de aprendizagem seja encarada como uma, ainda que especial, entre várias outras. Para os estudiosos das teorias de transição, ao gesto de aprender, como um todo, subjaz uma rede de funções mentais que processa informações novas, e é o entendimento dessas funções mentais que esses pesquisadores procuram alcançar com suas investigações, de modo a iluminar, com os achados advindos dessas pesquisas, seus questionamentos acerca da aquisição de línguas. Serão resenhados, a seguir, os trabalhos na área de maior relevância para a condução desta pesquisa, em duas partes: primeiramente, os modelos de processamento de informação e, em seguida, a teoria da processabilidade.

\subsubsection{Processamento de informação ${ }^{115}$}

\begin{abstract}
A memória nos enriquece com seus conteúdos, empresta cor, profundidade e significado às nossas percepções, mas também esconde ciladas. Armazena um pouco de tudo que foi vivido, experimentado. Dados, sensações, sentimentos e saberes estão aí guardados, segundo um código de acesso próprio e quase que desconhecido do sujeito que lembra "coisas enterradas no fundo do rio da vida. Na maturidade, no acaso, elas se desprendem e sobem à tona, como bolas no ar". (CAMARGO, 1998) ${ }^{116}$
\end{abstract}

(ANDRÉ et al., 2006, p. 25)

Je mehr wir lernen, desto mehr wissen wir.

Je mehr wir wissen, desto mehr vergessen wir.

Je mehr wir vergessen, desto weniger wissen wir.

Je weniger wir wissen, desto weniger vergessen wir.

Je weniger wir vergessen, desto mehr wissen wir.

Warum also lernen?

(Autor deconhecido)

\footnotetext{
${ }^{115} \mathrm{O}$ eixo condutor da redação deste sub-capítulo é Mitchell; Myles (2004), como indicado, embora o texto tenha sido preenchido com outras leituras e referências que foram adquiridas durante o levantamento bibliográfico.

${ }^{116}$ A referência é CAMARGO, I. Gaveta dos guardados. São Paulo: Edusp, 1998.
} 
Os modelos teóricos investigados dedicados à questão do processamento informacional, ao procurarem descrever o modo como o cérebro lida com as novas informações às quais é exposto, centram-se invariavelmente na questão da memória ou, melhor dito, das memórias ${ }^{117}$. De certa forma, é possível traçar um paralelo entre as propostas de alguns dos principais expoentes destes modelos (BIALYSTOK, 1978; McLAUGHLIN, 1987, 1990; ANDERSON, 1983, 1985; SINCLAIR; RENOUF, 1988; KLEIN, 1984 etc.) e a hipótese da aquisição vs. aprendizagem de Krashen (1982). Na referida hipótese, Krashen propunha a existência de dois processos distintos de assimilação de sistemas linguísticos não maternos, sendo um de ordem inconsciente, automática e "natural" e, o outro, consciente, dirigido, baseado em regras e em treino. De maneira semelhante, os autores mencionados, cada qual à sua forma, propuseram a existência de pelo menos dois níveis para a memória humana, sendo um responsável por processos automáticos e outro, pelos controlados. Estes comentários, meramente introdutórios, não pretendem simplificar uma questão de alta complexidade. Além disso, vale lembrar que, se para Krashen o aprendizado não conduziria à aquisição, para alguns desses autores o conhecimento explícito ou declarativo poderia vir-se a automatizar - embora afiançasse Paradis (apud PIENEMANN, 1998, p. 41), "what is automatized is not the explicit knowledge of the rule, ... but its application". E, como nos lembra Stanich (2008), é consenso, na atualidade, que a memória humana compõese de uma pluralidade de módulos independentes e interativos. Verifiquemos, portanto, no que consistiram as propostas de alguns dos principais estudiosos da área.

Para McLaughlin (1978), distinguem-se duas formas de armazenamento de informação na mente, que funcionam em paralelo: de um lado, o armazenamento controlado, que requer atenção e pelo qual é responsável a limitada memória de curta duração; de outro, o automático, que não requer atenção e está associado à memória de longa duração. A automatização, dependente de repetições, dista da simplicidade. O aprendizado de línguas estrangeiras, para o autor, consiste num processo cognitivo per se: na aquisição de habilidades cognitivas complexas, a serem integradas a uma performance fluente através da prática e da subsequente automatização de "subhabilidades". Durante o processo de aprendizagem, a melhora na performance e as

${ }^{117}$ Sobre a importância de que se preste atenção nas teorias acerca da memória no contexto de ensinoaprendizagem, Bimmel et al. (2011) afirmam que os estudos acerca da memória, ao lado de outros, advindos da linguística e da psicologia do desenvolvimento, são influentes no desenvolvimento de livros didáticos. 
automatizações são acompanhadas de reestruturações, à medida que os aprendizes manipulam e ganham maior controle sobre suas representações linguísticas internas (McLAUGHLIN, 1987). Pode-se asseverar que, para o autor, a aprendizagem consistiria numa passagem de processos controlados para automáticos por meio da prática, da repetição e de constante reestruturação, processo caracterizado por mudanças descontínuas ou qualitativas do sistema interlinguístico (McLAUGHLIN, 1990), com eventuais desestabilizações e aparições de erros na produção do aprendiz. A reestruturação está associada aos denominados três U-shaped patterns (GASS; SELINKER, 2008). No primeiro desses estágios, o aprendiz produz formas linguísticas "corretas", id est, correspondentes às utilizadas pelos falantes da língua-alvo; num segundo momento, a desestabilização interlinguística provoca uma aparente "perda" do que o estudante previamente sabia e a incidência de erros afetando as mesmas estruturas antes dominadas no estágio um; por fim, o aprendiz retorna qualitativamente ao nível de produção da primeira etapa. Explica Ellis (2006, p. 23): "it is clear that this occurs because learners reorganize their existing knowledge in order to accomodate new knowledge" ${ }^{118}$. Kleppin (1998, p. 39) assim resume a questão:

\begin{abstract}
Die Sprache des Lernenden ist - so wissen wir aus Erfahrung - nicht etwas, was sich linear und gleichmäßig vom Nullpunkt bis hin zur Perfektion entwickelt. Der Lernende bildet ein spezifisches Sprachsystem heraus, das zwar Merkmale der Muttersprache und der Zielsprache aufweist, das aber auch ganz spezifische Merkmale besitzt, die keine der beiden Sprachen hat. Man spricht hier von Interlanguage oder Interimsprache. Dieses ganz spezifische Sprachsystem ist variabel, durchlässig und instabil, es verändert sich in Richtung Zielsprache, kann sich allerdings ebenso zurückbewegen in Richtung auf ein schon überwunden geglaubtes Stadium. [...] Die Interlanguage wird außerdem nicht nur als flexibel beschrieben, sondern gleichzeitig als systematisch, $d$. h., sie befindet sich zwar in Veränderung, ist aber dennoch, z. B. für bestimmte Strukturen, fast wie eine eigene Sprache $z u$ beschreiben. Gerade auch an der Fehlerentwicklung lässt sich aufzeigen, wie sich die Lernersprache entwickelt und wie sich ein Lernender sein eigenes System aufbaut und konsequent bestimmte Fehler immer wieder macht (z. B. Wortstellung im Nebensatz). ${ }^{119}$
\end{abstract}

\footnotetext{
118 "Está claro que isto ocorre porque estudantes reorganizam o seu conhecimento existente, de modo a acomodar conhecimento novo".

119 “A língua do aprendiz não é - e isso sabemos a partir da experiência - algo que se desenvolva de forma linear e uniforme de um ponto de partida rumo à perfeição. O aprendiz constrói um sistema linguístico específico, que aponta para traços da língua materna e da língua-alvo, mas que também possui traços específicos que nenhuma das duas línguas tem. Fala-se, aqui, de interlíngua. Esse sistema linguístico específico é variável, permeável e instável, modifica-se em direção da língua-alvo mas também pode retroceder rumo a um estágio que se acreditava superado. [...] Além disso, a interlíngua não é descrita apenas como flexível, mas sim, ao mesmo tempo, como sistemática, i.e., ela se encontra em mudança, mas pode, por exemplo no caso de algumas estruturas, ser descrita como uma língua. Também por meio do desenvolvimento de erros pode-se indicar como a língua do aprendiz se desenvolve e como o
} 
Uma automatização prematura de uma forma linguística incorreta durante os períodos de desestabilização conformaria, de acordo com o modelo de McLaughlin, um exemplo de fossilização ${ }^{120}$, tema abordado no item anterior deste trabalho. E, como pontuam Gass \& Selinker (2008, p. 232), "with time and with experience in specific linguistic situations, learners begin to use language more automatically, thus leaving more attentional resources for new information that requires more control" ${ }^{121}$.

Considera-se válido sublinhar que Squire; Zola-Morgan (1991) propõem uma divisão parecida da memória em declarativa e procedimental, ressaltando, porém, as diferenças entre os tipos de dados armazenados em cada uma delas. A memória declarativa, para os autores, compreenderia uma subdivisão em memória semântica (para fatos) e episódica (para acontecimentos) - divisão também encontrada em Baddeley et al. (2011). À procedimental, em seu turno, corresponderiam os seguintes blocos:
1. hábitos e habilidades;
2. indução ou pré-ativação;
3. condicionamento clássico (associações emocionais e motoras) e
4. aprendizagem não-associativa (adaptação a estímulos de variável grau de importância).

Semelhante ao de McLaughlin é o modelo active control thought (ACT) de Anderson (1983, 1985), destacando-se, contudo, variações terminológicas no que se refere às memórias. Em vez de curta e longa duração, o autor optou pelas designações

aprendiz constrói seu próprio sistema e repetidamente comete determinados erros (p. ex. a ordem de palavras numa oração subordinada)".

120 Atualmente observa-se, em alguns casos, a tendência a empregar com maior cautela o termo "fossilização". Para muitos em nossa área, a aceitação desse conceito como verdade implicaria a anulação da validez de nossos esforços enquanto educadores para promover a apropriação do sistema linguístico estrangeiro por parte do aluno, o que suporia desconsiderar suas possibilidades de continuar reorganizando seu novo sistema linguístico e, igualmente, sua própria capacidade de aprender. Essa questão não parece ser abordada com maior importância em alguns trabalhos relativamente recentes sobre fossilização que localizei e citei, como Percegona (2005). Entretanto, Bona (2008) fala numa possibilidade de reversão da fossilização através do fornecimento de feedback corretivo, enquanto pondera que é necessária a realização de estudos longitudinais para verificar a possibilidade concreta dessa reversão.

121 “Com o tempo e com experiência em situações linguísticas específicas, os aprendizes começam a usar a língua mais automaticamente, deixando, assim, mais recursos de atenção disponíveis para informação nova que requer mais controle". 
conhecimento declarativo (saber que) e conhecimento procedimental (saber como). Entretanto, como em McLaughlin, em Anderson também se considera a prática a chave para a transposição do estágio declarativo para o procedimental e, assim, para a automatização do conhecimento. Essa passagem se daria em três passos:

1. o estágio cognitivo, durante o qual se aprende a descrição de um procedimento;

2. o estágio associativo, quando se processa o conteúdo, que é associado a estruturas previamente conhecidas, e

3. o estágio autônomo, da ativação e automatização da performance linguística (MITCHELL; MYLES, 2004).

Neste modelo, propõe-se ainda a existência de uma memória de trabalho, semelhante à de curta duração de McLaughlin, e dois tipos de memória de longa duração: uma declarativa e outra procedimental. Em seus primeiros trabalhos, Anderson haveria afirmado que todo conhecimento, antes de ser automatizado, teria de passar por uma fase declarativa; anos depois, o estudioso reconheceu não ser sempre este o caso. Segundo Towell; Hawkins (1994) e Bialystok (1991), nem todo o conhecimento gramatical é adquirido, mesmo em sala de aula, de forma declarativa. Um exemplo de informações dessa índole assimiladas diretamente de modo procedimental são os chunks que, ao serem analisados apenas a posteriori pelo aprendiz, consistem num percorrido inverso dessa sequência, até que sejam finalmente armazenados após a análise e reestruturação. $\mathrm{O}$ mesmo se dá com paradigmas de flexão diretamente gravados pelos aprendizes.

Relevante é a aplicação, por parte de O'Malley; Chamot (1990), do modelo ACT de Anderson ao campo das estratégias de aprendizagem, aqui compreendidas como aquelas levadas a cabo pelos estudantes com vistas a tornar seu aprendizado o mais eficiente possível, bem como a facilitá-lo. Segundo Mitchell; Myles (2004, p. 107),

a good language learner will be a learner who has proceduralized the strategies [...]. [...] before a skill is proceduralized, it will have to compete for working memory space with other aspects of the task in hand; as the working memory has strictly limited capacity, learning strategies which have not yet been fully proceduralized might not be applied because of 
competing demands. ${ }^{122}$

Assim, uma importante implicação concernente aos modelos há pouco apresentados é a temática das limitações, em capacidade e em duração (PIENEMANN, 2003), intrínsecas à memória de curta duração - ou à memória de trabalho, definida na maior parte dos modelos, de acordo com Baddeley et al. (2011, p. 22), como "forma de espaço operacional mental, oferecendo uma base para ponderações". De fato, no que tange o par de termos "memória de curta duração" e "memória de trabalho", que por vezes se confundem na literatura, convém lembrar as observações a respeito de Gass \& Selinker (2008, p. 250), que resumem: "The major difference is that working memory focuses on the manipulation of information rather than just the storage of information, as [i]s the case with short-term memory"123. Antes que uma informação possa ser automatizada, ela competirá por espaço na memória de curta duração com outras novas informações, o que poderá comprometer o sucesso da operação. Isso tem notórios efeitos em sala de aula e na definição de quanto insumo novo deva ser oferecido de uma só vez aos aprendizes (remetendo-se aqui, desse modo, à hipótese do i+1 de Krashen). Também é de alta relevância o papel das revisões quando da mediação da construção de novos conhecimentos, por parte do alunado, uma vez que a informação nova deverá ser ancorada em dados previamente processados e já armazenados na memória de longa duração. É assim que reproduzo o pensamento de Edmondson (2002, p. 56) a respeito, segundo quem

bei der Begegnung mit der Fremdsprache aktiviert der Lerner verschiedene Kenntnisse und Wissensquellen, zum Beispiel bei dem Versuch, einen fremdsprachlichen Text zu verstehen. Ferner muss das aus dem Input Gewonnene als Datei im Gehirn gespeichert und möglicherweise weiter verarbeitet werden. ${ }^{124}$

\footnotetext{
122 "Um bom aprendiz de lingua será aquele que "proceduralizar" [proceduralize] as estratégias [...]. Antes de que uma habilidade seja proceduralizada, ela terá de competir por espaço de memória de trabalho com outros aspectos da tarefa em questão; como a memória de trabalho tem capacidade muito limitada, estratégias de aprendizagem que não foram ainda completamente proceduralizadas não deverão ser aplicadas devido a demandas que competem com elas".

123 “A principal diferença é que a memória de trabalho foca na manipulação de informação, em vez de apenas no armazenamento de informação, como no caso da memória de curta duração".

124 "No contato com a língua estrangeira, o aprendiz ativa diferentes conhecimentos e fontes de saberes, por exemplo quando da tentativa de entender um texto em língua estrangeira. Assim, aquilo que foi adquirido através do insumo deve ser armazenado como dados no cérebro e, possivelmente, ser processados mais adiante".
} 
A partir dos fundamentos teóricos aqui resenhados, percebe-se que, grosso modo, os conceitos de "memória de trabalho" e "memória de curta duração" ocorrem de forma mais ou menos paralela na bibliografia, ainda que, como esboçado, autores como Gass e Selinker (2008) hajam procedido a uma diferenciação entre ambas. Acredito, porém, que o primeiro termo desse par seja mais adequado quando de uma referência mais geral às instâncias da memória, devido ao fato de que, sistematicamente, no seio das teorias psicolinguísticas acerca da ativação da memória durante a aprendizagem, não ocorrem quantificações temporais quanto à capacidade de armazenamento ou processamento de dados ${ }^{125}$. Desse modo, poderiam emergir perguntas como "quais são as dimensões temporais da memória de curta duração?"; "trata-se de segundos ou minutos, e quantos?" Como dito, essas respostas não estão disponíveis entre textos consagrados de psicolinguistas, que se dedicam a essa temática de forma mais geral e sem preocupações com a medição temporal das memórias. Como afirmam Stanich; Meireles (2009, p. 182),

\begin{abstract}
a ideia de que a memória como um todo ou qualquer um de seus subsistemas privilegie o decorrer do tempo como fator determinante na manutenção, transferência ou descarte de seus conteúdos é controversa. Além disso, até o momento, não há consenso sobre o limite temporal que determinaria a passagem da informação do sistema de curta para o de longa duração. Trabalhos nas áreas de psicologia, neurologia e neurociência mencionam prazos de minutos, de vinte e quatro horas e até de anos para a consolidação de itens da memória.
\end{abstract}

Por esse motivo, "memória de trabalho" é um termo que evita as perguntas supracitadas e conduz a atenção do leitor às características gerais dessa instância da memória, e não à sua duração. Com isso não se quer, entretanto, subtrair os méritos de cada modelo teórico, dentro do qual cada autor lança mão de sua própria terminologia.

De forma a complementar estas reflexões acerca do processamento de informações, exploremos, em seguida, os postulados principais da Teoria da Processabilidade, que também abarca questões acerca da memória e da ordem de processamento informacional, e nos traz informações reveladoras sobre o processamento das orações subordinadas alemãs, entre as quais se encontram as relativas, tema deste trabalho.

\footnotetext{
${ }^{125}$ Não se pretende, neste trabalho, realizar estudos de natureza cognitivista, neurológica, neurolinguística ou psicológica sobre o processamento e armazenamento de dados nas memórias.
} 


\subsubsection{Teoria da Processabilidade}

Es liegen aus der Spracherwerbsforschung seit längerem klare Belege dafür vor, dass sich Sprachlernprozesse, was den Erwerb eines Kernbereichs der Grammatik betrifft, in ihrem Verlauf interindividuell und unabhängig von der gelernten Sprache erstaunlich gleichen. Alle Lerner durchlaufen dieselben Entwicklungsstufen und machen auf jeder Stufe typische Fehler, die unvermeidbar zu sein scheinen. Das gilt, wenn man auf die in freier Rede produzierten Sprachäusserungen schaut, auch für Fremdsprachenlerner, die einen formalen Unterricht in Grammatik erhalten.

(MULTHAUP, 2002, p. 72)

No marco do denominado modelo multidimensional de Clahsen et al. (1983), com base no modelo de Levelt (1989) para a geração da linguagem, situa-se a Teoria da Processabilidade (TP). Embora difira muito de estudos setentistas como os referentes à ordem de aquisição de morfemas, a TP representa uma retomada do interesse pela problemática das sequências de aquisição. Esse modelo de Pienemann (1998), em partes herança das reflexões de Levelt e tendo como base, ainda, a Gramática Léxico-funcional de Kaplan \& Bresnan (1982), pressupõe a existência de um "sistema de produção de linguagem [...] formado por três componentes de processamento e duas unidades de armazenagem de conhecimento que são usadas em cooperação com o sistema de compreensão de linguagem” (RAUTH, 2002, p. 35). Como resume Marciniuk (2007, p. 13), “a lógica subjacente à Teoria da Processabilidade (TP) é que em qualquer estágio do desenvolvimento, o aprendiz pode produzir e compreender somente aquelas formas linguísticas da L2 que o estágio atual do processador linguístico pode perceber”. Assim sendo, a TP estabelece fases para a progressão da aquisição ou automatização de estruturas morfossintáxicas que não podem deixar de ser trabalhadas durante a instrução formal, sendo que uma fase subsequente sempre pressuporá a pregressa. Para Pienemann (1998), e em consonância com sua teachability hypothesis, a instrução formal será mais benéfica à medida que focar em aspectos do estágio vindouro.

Em um primeiro momento, a validez dessas observações é de fácil constatação em sala de aula. Professores indagam-se a respeito das causas pelas quais aprendizes adultos mostram-se capazes de compreender e aplicar, em exercícios de fixação, praticamente qualquer estrutura estudada (desde que a partir de uma progressão razoável), sem que se observem aptos a aplicá-la sistematicamente, de modo espontâneo 
e automático, em suas produções livres (exercícios produtivos, na tipologia de NEUNER et al., 1981), orais e escritas. Confirmam estas reflexões Diehl et al. (2002, p. 143):

\begin{abstract}
Wer mit fremdsprachlicher Grammatik zu tun hat - sei es als Lernende, sei es als Unterrichtende - weiss, dass zwischen Regelkenntnis und Regelanwendung zuweilen ein sehr langer Weg liegen kann. Man mag gegen Krashens plakative Unterscheidung zwischen "Lernen" (als der Aneignung expliziten Regelwissens) und "Erwerben" (als der Fähigkeit spontaner Regelanwendung in der Kommunikation) vielerlei einzuwenden haben unbestritten ist, dass explizites Regelwissen noch keineswegs die fehlerlose Anwendung dieser Regeln garantiert.
\end{abstract}

Ora, é preciso investigar se a apresentação dos conteúdos de índole morfossintáxica tem respeitado as sequências de aprendizagem postuladas pela TP. A respeito, prosseguem as autoras:

\begin{abstract}
Inwieweit der schulische Grammatikinput zum "Intake" werden kann, hängt unter anderem davon ab, inwieweit die entsprechende Grammatikinformation zum "richtigen" Zeitpunkt gegeben wird, d.h. dann, wenn die vorangegangenen Phasen als erworben gelten können und somit die Voraussetzungen für den Erwerb der neuen Form oder Struktur gegeben sind. (op. cit., p. 145)
\end{abstract}

Deve-se observar, ainda, se se está desenvolvendo, em curso, um trabalho que leve em conta a memória ou, melhor dito, as memórias dos aprendizes. A assimilação de uma dada estrutura, assim como de qualquer informação que se possa aprender, será bastante simplificada uma vez que o aluno detenha, em sua memória de longa duração, conhecimentos prévios acerca de aspectos do novo conteúdo com o qual se esteja confrontando. Assim, seria possível acessar esses pré-conhecimentos de modo a interrelacioná-los com os novos inputs. Nesta direção aconselhava Ausubel (apud EDMONDSON; HOUSE, 2006, p. 96), que "das Wichtigste beim Lernen ist das, was der Lerner schon weiß. Stellen Sie dies fest, und bauen Sie Ihren Unterricht darauf auf."126

Pienemann (1998) deixa entrever, a partir da análise de estudos dedicados à ordem de aquisição de estruturas (regras concernentes à ordem de palavras na frase) do alemão por falantes não nativos, que as construções com verbo ao final, típicas das

\footnotetext{
126 "O mais importante, durante a aprendizagem, é aquilo que o estudante já sabe. Constate isso e construa sua aula com base nessa informação".
} 
orações subordinadas, corresponderiam à última fase de aquisição de regras sintáxicas de colocação verbal. Entre os tipos de oração desse feitio, um acentuado grau de dificuldade é atribuível às Relativsätze alemãs, foco da parte experimental deste trabalho e tópico gramatical de alto grau de dificuldade que eventualmente induz o aprendiz a uma série de equívocos também durante a realização de exercícios escritos de fixação. As orações relativas do alemão não implicam apenas a situação do verbo ao final da frase, mas também a introdução da sentença por um pronome relativo sujeito a variações de gênero, número e flexão de caso, em completa disparidade com o sistema congênere português. Como expõem Mitchell; Myles (2004, p. 112):

The basic logic behind Processability theory is that learners cannot access hypotheses about the second language that they cannot process. They are claimed to have a Hypothesis space, which develops over time according to the following hierarchy of processing ressources (Pienemann, 1998, p. 87):

- Level 1: lemma access; words; no sequence of constituents.

- Level 2: category procedure; lexical morphemes; no exchange of information - canonical word order.

- Level 3: phrasal procedure; phrasal morphemes;

- Level 4: simplified S-procedure; exchange of information from internal to salient constituent.

- Level 5: S-procedure; inter-phrasal morphemes; exchange of information between intenal constituents.

- Level 6: Subordinate clause procedure.

Segundo os resultados do projeto ZISA, a sequência básica e cumulativa de aquisição de regras de funcionamento linguístico corresponderia a (PIENEMANN, 1998, p. 45):

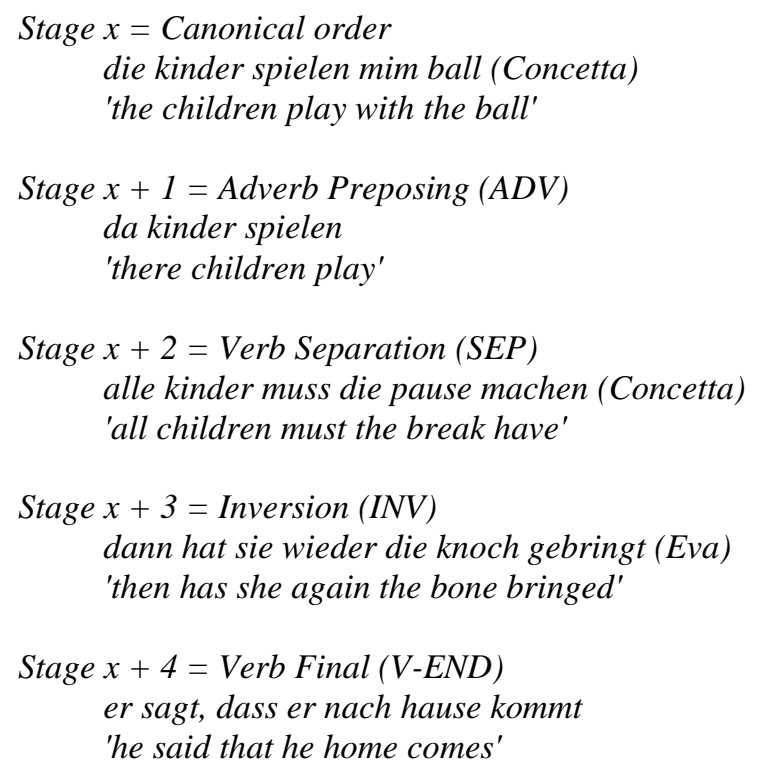


Como se pode notar no esquema acima transcrito, o primeiro estágio desse eixo de desenvolvimento a ser percorrido pelos aprendizes corresponde à ordem canônica das sentenças alemãs, a saber, SVO (sujeito-verbo-objeto) - sem que se considerem aqui, como bem lembram Gass; Selinker (2008), palavras soltas aprendidas e chunks. Num segundo momento, principia-se a anteposição do advérbio, construção extremamente comum no alemão que, contudo, exige a colocação do verbo na segunda posição sintática da frase - fenômeno que ainda não ocorre neste momento. No terceiro estágio, observa-se a chamada Satzklammer - trata-se de estruturas compostas de dois verbos em que um, conjugado, situa-se na segunda posição da frase e o outro, no infinitivo ou particípio, desloca-se ao final. Em seguida, apresenta-se a inversão ausente no estágio dois para que, no estágio quatro, por fim, sejam produzidas as orações subordinadas com verbo ao final da frase. Clahsen (1984) procurou explicar os resultados da pesquisa ao elencar três estratégias hierarquizantes, pressupondo sempre as anteriores, de ordenamento e reestruturação correspondentes, por sua vez, "ao grau de complexidade psicológica envolvido na produção de uma determinada regra de ordem de palavras" (RAUTH, 2002, p. 74):

1. Estratégia de ordem canônica: sem qualquer tipo de permuta ou reordenação estrutural.

2. Estratégia de Iniciação/Finalização: não há permutas no interior, mas sim do início para o fim da frase e vice-versa.

3. Estratégia de oração subordinada: movem-se elementos do interior de uma sentença, mas não em subordinadas.

Um aspecto muito importante da TP é justamente a supramencionada teachability hypothesis com suas implicações (estágios não devem ser omitidos e o foco da instrução formal deve ser o próximo estágio), juntamente com seus possíveis efeitos em sala de aula. A TP oferece insumos para reflexões acerca de como lidar com a interlíngua dos aprendizes, com seus processos de formulação de hipóteses e, principalmente, com seus erros considerados inevitáveis em determinadas fases do processo de aprendizagem. O mesmo se aplica à definição de currículos, no tocante aos conteúdos de tipo gramatical, uma vez se pretenda ter como foco a fase adequada a abordar em curso. 
Além dos estágios de processamento linguístico e sua hierarquia, Pienemann insistiu também no princípio denominado perceptual saliency, um conceito advindo da área da psicologia cognitiva, segundo o qual, no contexto da TP, o início e o final dos estímulos são mais facilmente relembrados e manipulados. A abordagem da saliência perceptual (SLOBIN, 1985; ANDERSEN, 1984 e 1990, com base em trabalhos de Slobin nos anos setenta e oitenta) assenta-se sobre a assunção de que percebemos e organizamos informações de maneiras específicas. De acordo com este modelo teórico, seria a partir da saliência perceptual de informações de cunho linguístico que se desenvolveria o processo de aprendizado, e não a partir de um módulo inato de aquisição da linguagem. Slobin desenvolveu uma lista de princípios operacionais do processamento linguístico infantil que foram devidamente adaptados por Andersen ao contexto da aquisição de línguas não maternas (MITCHELL; MYLES, 2004; ELLIS, 1999).

Por fim, vale ressaltar que elementos-chave das teorias de processamento de informação e da TP consistem em importantes insumos básicos a serem considerados na condução dos testes que justificam a elaboração deste texto. É tecendo uma ponte entre estas teorias e as formas como se ensina e aprende gramática de LE a partir da adoção de certos livros didáticos que o próximo capítulo tratará das abordagens analítica e sintética de trabalho gramatical. 


\subsection{Análise e síntese no ensino de gramática}

Neste capítulo, pretende-se tratar das chamadas abordagem sintética e analítica no ensino de língua estrangeira em cursos em que se dá a utilização de livros didáticos, (embora, como será mencionado adiante, a determinação de um processo de progressão de tópicos gramaticais a partir de cada uma das abordagens pode ser determinada pelo professor, em curso, com ou sem o emprego de um LD). Para tal, será empregada a distinção entre análise e síntese cunhada por Wilkins (1978). A adoção desse modelo teórico se justifica uma vez que a essas duas abordagens corresponde o trabalho com conteúdos gramaticais nos dois LD a serem analisados, e também porque isso se reflete acentuadamente no que diz respeito à apresentação das Relativsätze em ambas as obras.

No primeiro capítulo de seu texto, o autor expõe suas visões acerca do papel da gramática nos cursos de LE. Para ele, dominar a gramática de uma língua consiste no objetivo central da maior parte dos cursos, afirmando, ainda, que o componente gramatical ocupa a posição principal no processo de ensino-aprendizagem ${ }^{127}$. Entretanto, ele menciona algumas críticas que pesquisadores expressam nesse sentido, afirmando, em alguns casos, que o estudante não se tornará fluente na língua apenas por haver dominado tópicos de natureza gramatical.

Também a respeito do papel da gramática em cursos de LE e no seio dos diferentes métodos e abordagens de ensino, defendi num escrito (MING, 2012, p. 122) que

\footnotetext{
la gramática, vilipendiada y condenada por muchos profesores y alumnos a lo largo del tiempo como una traba al aprendizaje, consiste en parte indisociable de la lengua, que se puede enseñar de forma implícita o explícita, pero jamás optarse a no enseñar. [...] Su papel siempre ha sido central en los procesos de enseñanza de idiomas, aunque por veces se haya pretendido ignorarla o tratarla de forma negligente. ${ }^{128}$
}

\footnotetext{
${ }^{127}$ Essa perspectiva se viu bastante modificada, como já se alertou anteriormente, a partir da virada comunicativa e do depósito de maior ênfase nas funções comunicativas da produção de linguagem.

128 “A gramática, vilipendiada e condenada por muitos professores e alunos ao longo do tempo como um entrave à aprendizagem, consiste em parte indissociável da língua, que se pode ensinar de forma implícita ou explícita, nunca podendo, porém, optar-se a não ensinar. [...] Seu papel sempre foi central nos processos de ensino de línguas, embora por vezes se tenha pretendido ignorá-la ou tratá-la de forma negligente".
} 
Tal é a importância atribuída por Wilkins (1978) ao ensino de gramática que o autor afirma ser a meta cabal de um curso de LE ensinar, dentro do possível, todo o sistema gramatical da língua em questão ${ }^{129}$. Assim, concebe dois enfoques distintos para o trabalho com conteúdos de cunho gramatical, a saber, o sintético e o analítico. O primeiro consiste no trabalho com os conteúdos gramaticais de forma separada e pouco a pouco, oferecendo ao aluno pequenas porções de gramática por vez, espraiadas ao longo de diversas lições, gradualmente, enquanto esses insumos parciais se acumulam até que a estrutura completa esteja constituída. Essas pequenas partes deverão ser completadas por aquelas que serão oferecidas na próxima lição, cabendo ao aluno juntar as peças rumo ao domínio paulatino do sistema gramatical completo. Trata-se do tipo de progressão gramatical observada em studio $d^{130}$.

$\mathrm{O}$ autor prossegue e retoma conceitos importantes difundidos na área da Linguística Aplicada. Segundo Wilkins, a apresentação desses itens gramaticais é comumente determinada por critérios pré-estabelecidos, tais como simplicidade, regularidade, frequência e dificuldade contrastiva. Eles se referem, desse modo, à adequação dos conteúdos ao estágio de aprendizagem dos alunos, de forma descomplicada e adaptada aos interesses próprios de não-linguistas, bem como ao ensino dos itens linguísticos mais produtivos antes dos mais raros, à maior ocorrência da forma no uso da língua e à necessidade de evitar-se ensinar construções que apresentem considerável dificuldade contrativa nas primeiras fases do processo de aprendizagem.

\footnotetext{
${ }^{129}$ Entretanto creio, de acordo com os pressupostos comunicativos (e, por que não, pós-comunicativos) de ensino-aprendizagem de LE e também em concordância com as propostas do QECR, que basta ensinar explicitamente aquelas estruturas gramaticais diretamente envolvidas na elaboração de atos de fala (e escrita - enfim, em processos comunicativos) previstos no programa de curso. Isso dependerá, naturalmente, do foco do curso em questão e das necessidades, desejos, expectativas e crenças do alunado, bem como do estágio de aprendizagem em que se encontrem e que almejem atingir. $\mathrm{O}$ ensino da gramática completa de uma língua por si só não é desejável e não se justifica junto a aprendizes que apenas desejem aprender a comunicar-se em alemão em situações reais.

${ }^{130}$ Os autores do livro do professor do primeiro volume da série (studio d Al - Unterrichtsvorbereitung, BETTERMANN et al., 2005, p. 14) assim descrevem a proposta de trabalho com conteúdos gramaticais na obra, que denominam "cíclica": "Aufteilung grammatischer Strukturen in lernbare und funktional begründbare Teileinheiten: Lernbarkeit vor Vollständigkeit - Mit der Aufteilung der grammatischen Strukturen in lernbare Teile folgen wir Grundprinzipien einer zyklischen grammatischen Progression. Diese zielen darauf ab, die kognitive Belastung und Verarbeitungskapazität der Lernenden nicht zu überfördern und gleichzeitig eine Unterforderung zu vermeiden."
} 
Para Wilkins (1978, p. 1), o ensino passo a passo de conteúdos gramaticais é "the most obvious pedagogic strategy to adopt in planning to meet those objectives"131. Por sua vez, afirma-se acerca da abordagem analítica (Schritte International) que

\begin{abstract}
there is no attempt at this careful linguistic control of the learning environment. Components of language are not seen as building blocks which have to be progressively accumulated. Much greater variety of linguistic structure is permitted from the beginning and the learner's task is to approximate his own linguistic behaviour more and more closely to the global language. $(1978$, p. 2)
\end{abstract}

A partir destas reflexões, elementos de uma de nossas hipóteses de trabalho emergem novamente. A aprendizagem das orações relativas alemãs de acordo com um ou outro tipo de processo traz implicações relacionadas ao uso das memórias. É possível afirmar ser lógico que, a partir da abordagem sintética, a informação processada disponha de mais tempo para seu depósito na memória de longa duração/trabalho (MT) e que, no caso do ensino que tenha como base a abordagem analítica, entre a apresentação dos conteúdos e a aplicação de exercícios não seja plausível esse armazenamento informacional, saturando-se, assim, a limitada MT. Vale lembrar, ainda, que a editoração de livros didáticos de alemão LE pôs no mercado materiais contendo variações de abordagens no tocante à apresentação da gramática. Em dois LD bastante recentes e utilizados na maioria das escolas/institutos onde se ensina a língua em São Paulo, studio $d$ e Schritte International, observa-se, nesse sentido, a adoção de diferentes propostas. Tema de nosso trabalho, essa questão e suas implicações serão tratadas mais adiante, na segunda parte.

Faz-se ainda importante sublinhar, em concordância com o proposto no item 1.4 deste trabalho, que a adesão à abordagem analítica ou sintética em curso não é exclusivamente determinada pelo $\mathrm{LD}$ e pela forma como este último propõe a progressão da gramática. O professor, ao desempenhar seu papel criativo, autoral e/ou coautoral no processo de preparação de aulas e de materiais, e tendo-se em conta, também, as prescrições institucionais, pode decidir ensinar em discordância do que o LD sugere, antecipando ou atrasando a apresentação de temas aos estudantes, e tornando analítica uma progressão de conteúdos que o manual sugere como sintética, ou vice-versa.

131 "A estratégia pedagógica mais óbvia a dotar ao planejar-se atingir esses objetivos". 


\title{
2.4 A discussão contemporânea sobre o uso do livro didático de língua estrangeira
}

\begin{abstract}
Quando as pessoas querem aprender línguas hoje em dia, inevitavelmente acabam numa classe com um livro didático ou, quando sozinhas, com um conjunto de fitas gravadas nas mãos para guiar seus passos. A amostra de língua que os materiais didáticos contêm, com maior ou menor qualidade, é sempre pequena em relação ao tamanho da língua toda. [...]

A estrutura dos cursos e materiais convencionais é excessivamente rígida, arbitrária, e dela é difícil escapar. O livro didático traz o "prato feito" e as tentativas de modificá-lo requerem formação profissional sólida e bastante tempo disponível para levar a efeito a sua reformulação fundamentada.
\end{abstract}

(ALMEIDA FILHO, 2005, p. 17 e 19)

O fato desta pesquisa se basear em dados coletados junto a informantes que frequentam cursos em instituições nas quais se adotam livros didáticos ${ }^{132}$ requer a elaboração de um balanço do estado da arte atual das discussões a respeito do tema no âmbito da LA e de ALE. Assim, tratar-se-á deste assunto nos próximos parágrafos, com ênfase especial à questão do uso do LD no contexto do ensino-aprendizagem de línguas estrangeiras. Embora algumas temáticas advindas desses estudos sejam aplicáveis também ao LD de língua materna, opta-se, aqui, por não enfocar especificamente essas discussões, uma vez que não pertencem ao escopo desta pesquisa.

O LD, na parte ou no todo ${ }^{133}$, integra um grupo maior de materiais de apoio empregados por professores durante a condução de suas aulas, ao lado das apostilas, textos e imagens fotocopiados de elaboração própria, jogos didáticos, materiais multimidiáticos etc. Além da variedade de materiais extras disponível e daqueles criados pelo professor, os LDs contemporâneos costumam consistir em conjuntos que incluem recursos multimídia, como CDs, DVDs etc., "so dass für die genannte

\footnotetext{
${ }^{132}$ Como nos lembram Bimmel et al. (2011), em algumas línguas, como o francês, emprega-se a palavra "método" para referir-se ao LD. Em alinho com a tradição contemporânea brasileira, aqui não se empregará a palavra "método" com referência a LD, sendo que método, neste trabalho, é um termo que se refere às questões dos "métodos e abordagens de ensino" que se vão desenvolvendo com o passar do tempo. Ver Ming (2012) para uma reflexão a respeito do papel, escopo e espaço da gramática durante o predomínio dos diferentes métodos e abordagens.

${ }^{133}$ Pois se dá frequentemente o caso em que, adote-se ou não um LD para a condução de um dado curso, o professor lança mão de partes extraídas de LDs que fotocopia e entrega aos aprendizes, ou se inspira nas atividades contidas num LD para a elaboração de suas próprias atividades. Ou seja, há contextos em que o LD é adotado em sua totalidade ou apenas parcialmente, e circunstâncias em que sua aplicação é direta ou indireta (adaptada).
} 
Produktpalette allein für einen Al-Lehrwerkband bereits sechstellige Vorkosten anfallen" $^{\prime 134}$ (FUNK, 2010, p. 69).

Quanto às funções exercidas pelo LD de LE, Neuner (apud UPHOFF, 2008, p. 134) assim as elenca:

\footnotetext{
- operacionaliza[r] o currículo e defin[ir] os objetivos do curso de línguas; - determina[r] a progressão, ou seja, a escolha, o peso e a sequiência dos conteúdos;

- defin[ir] os procedimentos didáticos e os tipos de organização social na aula $[\ldots]$;

- regula[r] o uso das diversas mídias (fitas, filmes etc.) durante a aula; e

- defin[ir] a avaliação do progresso de aprendizagem dos alunos.

Conforme o mesmo autor, nenhum outro fator influencia tanto os acontecimentos na sala de aula de língua estrangeira. Essa avaliação é confirmada em diversas pesquisas sobre o assunto feitas no Brasil.
}

Quanto às suas vantagens, Richards (s/d) elenca os seguintes aspectos: os LDs oferecem estrutura para um programa didático, ajudam a estandardizar o ensino, a manter a qualidade ("if a well developed textbook is used students are exposed to materials that have been tried and tested, that are based on sound learning principles, and that are placed appropriately"135 - op. cit., p. 1), fornecem uma grande variedade de mídias e recursos para a aprendizagem, são eficientes, podem apresentar modelos e insumos linguísticos de qualidade, auxiliar no treinamento de professores menos experientes e são atrativos visualmente. Entre as desvantagens de seu uso, porém, o autor menciona o fato de o LD conter amostras não-autênticas de linguagem, a distorção de conteúdos por basearem-se em uma visão idealizada de mundo, a possível falta de conexão com as necessidades dos aprendizes, a redução do professor - no caso de aulas totalmente perfiladas pelo $\mathrm{LD}$ - a técnicos cuja função consiste em apresentar materiais elaborados por outrem e, por fim, o seu alto preço. Além disso, como menciona o estudioso, enquanto os autores se preocupam com criar um material efetivo e de qualidade que ajude no ensino-aprendizagem, não se deve esquecer a presença dos interesses de natureza financeira dos editores, embora, como menciona, "publishers

\footnotetext{
134 “de tal modo que, sobre o conjunto de produtos que compõem os materiais equivalentes apenas a um LD em nível A1, incidem custos de produção da ordem de seis dígitos”.

135 "Se um livro didático bem elaborado é utilizado, os estudantes são expostos a materiais que foram testados e aprovados, que são baseados em princípios de aprendizagem pertinentes e que estão dispostos de forma apropriada".
} 
generally recongnize that a book must have qualities of excellence that will distinguish it from its competitors" ${ }^{\prime 136}$ (p. 3).

Embora possa ser considerado o material mais empregado e de maior peso em contextos educacionais formais, chegando a corresponder, eventualmente, "à única fonte de consulta e de leitura dos professores e dos alunos" (CORACINI, 1999, p. 17), ou ao "Löwenanteil im Unterricht"137 (BIMMEL et al., 2011, p. 7), o livro didático tende a competir, em sala de aula, com os materiais elaborados pelo professor de forma individual, em colaboração com outros ou em nome da instituição em que trabalha ${ }^{138}$. Deste modo, reclama-se o reconhecimento do professor que assim procede como um verdadeiro autor de materiais (UPHOFF, 2009). Mas, apesar da variedade de materiais à disposição e da possibilidade de o professor elaborar seus próprios recursos, o LD permanece sendo o material de apoio mais utilizado e mais influente na preparação e condução de aulas de LE, com Richards (s/d, p. 1) afirmando que "much of the language teaching that occurs throughout the world today could not take place without the extensive use of commercial textbooks"139.

Neste ínterim, é imprescindível lembrar que, em grande parte dos casos, a ação didática do professor, associada ao emprego do LD, está subordinada, de modo mais ou menos controlado, às prescrições institucionais, o que significa que nem sempre lhe será possível (caso o deseje) atuar como autor dos próprios materiais e decidir os ditames de seu próprio fazer pedagógico ${ }^{140}$. Uphoff $(2008$, p. 136) denuncia, por isso, o papel

\footnotetext{
136 "Editores geralmente reconhecem que um livro deve ter qualidades de excelência que o distinguam de seus competidores".

137 "a maior parte da aula".

${ }^{138}$ Além disso, como nos lembra Silva (2012, p. 179), "a oferta de ferramentas [de materiais] online para a aprendizagem de língua estrangeira, em especial o inglês, é abundante e cresce a cada dia".

139 "Grande parte do ensino de línguas que ocorre ao redor do mundo atualmente não aconteceria sem o uso extensivo de livros didáticos comerciais". Como se mostra na tabela 1a no apêndice, a adoção e o emprego de LDs perfila praticamente a totalidade do ensino de alemão para adultos em escolas de idiomas no estado de São Paulo.

${ }^{140}$ Uphoff (2008) trata do caráter institucional do LD à luz da teoria de Berger \& Luckmann acerca das instituições e institucionalizações. A autora menciona, no texto, as dificuldades do indivíduo em provocar mudanças em práticas institucionalizadas, lembrando-nos de que "a inserção em um ambiente institucionalizado sempre acarreta certa perda de autonomia para as pessoas envolvidas, que precisam respeitar 'as regras do jogo' para serem aceitas pela sua categoria” (op. cit., p. 133).
} 
coercitivo do LD de adoção institucional: "vale citar o papel dos estabelecimentos de ensino que, muitas vezes, exigem dos professores o uso de determinado livro nas suas aulas, no intuito de padronizar a grade curricular e, talvez, ter um meio para controlar a atuação de seus docentes".

Dão-se, assim, quando as realidades institucionais o permitam, duas realidades extremas às quais lança luz Coracini (1999, p. 23): o uso "constante e fiel" do LD versus a opção de simplesmente não adotá-lo. A autora considera a primeira postura mais cara aos professores de língua materna, enquanto que a segunda corresponderia, $a$ priori, aos de língua estrangeira. Entretanto, como já se afirmou acima, e também com base nos depoimentos dos professores-voluntários que participaram desta pesquisa, devidamente compilados no apêndice, considera-se que ambas as posturas dependerão muito mais amplamente das liberdades de que goze o professor ao decidir os destinos de seu agir profissional do que do fato de tratar-se do ensino de língua materna ou estrangeira $^{141}$. Além disso, é imprescindível reconhecer a presença de cenários que se estabeleçam entre esses dois extremos, como o caso da adoção tanto de um LD quanto de materiais autorais elaborados pelo próprio docente ou segmentos extraídos de outros manuais, casos bastante frequentes, ainda que certamente não ubíquos, nas IE que adotam livros didáticos, numa relação que se pretende complementar e simbiótica. Para especialistas como Lajolo (apud PONCIANO, 2008, p. 24), com quem concordo, a qualidade do trabalho com um LD dependerá sempre da atuação do próprio professor ${ }^{142}$ :

não há livro que seja à prova de professor: o pior livro pode ficar bom na sala de um bom professor e o melhor livro desanda na sala de um mau professor. Pois o melhor livro, repita-se mais uma vez, é apenas um livro, instrumento auxiliar da aprendizagem.

Nos casos em que LDs são adotados, percebe-se, como nos mostrava Neuner (apud UPHOFF, 2008), que uma de suas funções é sugerir (ou, a depender da relação

\footnotetext{
${ }^{141}$ Richards (s/d, p. 4) nos lembra, a respeito, que o papel do LD de apoio no processo de aprendizagem deve estar sempre claro.

${ }^{142}$ Entretanto não se pretende, neste trabalho, devido à temática circunscrita e às circunstâncias em que se deu a coleta de dados, devidamente descrita na parte segunda deste trabalho, estabelecer uma discussão maior acerca do trabalho do professor e prescrutar as condições "ideais" que caracterizariam o trabalho do "bom professor". Em linhas gerais, alinho-me com Cagliari (1996, p. 30), que afirmava que "quem lida com o ensino de linguagem tem que saber Linguística", e considero igualmente importantes a preparação e formação didático-metodológicas de qualquer profissional de ensino. Restringindo-me ao escopo deste trabalho, não discutirei, neste momento, mais profundamente a questão.
} 
que o docente e a instituição estabeleçam com ele, determinar) o conteúdo básico a ser explorado em sala de aula, bem como a sua progressão. Essa função assumiu especial relevância no contexto do ensino-aprendizagem de LE posterior ao surgimento do QECR. Como grande parte das escolas optou por aderir às premissas contidas no documento europeu (incluindo-se as duas que nos forneceram os dados analisados na parte terceira desta dissertação), a progressão conteudística do LD contemporâneo elaborado de acordo com o proposto no QECR parece funcionar como uma garantia de adesão a essas sugestões, de modo que os autores do livro assumem, assim, a responsabilidade de oferecer ao alunado insumos adequados a essas prescrições. Tratase do que Coracini (op. cit.) denomina parâmetros "reconhecidos" de que o professor que trabalha com um LD passa a dispor para a definição do que deve ensinar. Apesar disso, Uphoff (2009, p. 2) relembra o discurso de Wolff e faz referência ao chamado "paradigma construtivista", que "questiona a existência de uma progressão única e defende a importância de construir diversos percursos de aprendizagem em sala de aula", o que põe em xeque a suposta necessidade de que se adote a progressão de conteúdos do LD, ainda que uma adesão a ela possa ser esperada por parte da IE, como no caso dos professores-voluntários e seu depoimento (apêndice).

No caso dos livros do professor (Lehrerhandbücher) de Schritte International (KALENDER; KLIMASZYK, 2011) e de studio $d$ (FUNK et al., 2010b), esses materiais deixam bastante clara sua intenção de oferecer ao docente e ao aprendiz uma proposta de ensino-aprendizagem de ALE adequada ao QECR e por ele perfilada. Os autores se responsabilizam, também, por ofertar ao professor e ao aprendiz atividades para o desenvolvimento de intenções comunicativas, gramática, vocabulário, pronúncia e desenvolvimento consciente de estratégias de aprendizagem. A inclusão de exercícios que correspondem aos pressupostos da tipologia de Rampillon (2000) também denota a intenção de desenvolver, mediante essas atividades, a autonomia do aprendiz (CUNHA, $2013)^{143}$. São incluídas, ainda, atividades de leitura (de textos verbais e imagéticos), de compreensão auditiva, de expressão oral etc., de modo que o LD se apresenta como um pacote pretensamente completo, que tenta cobrir praticamente todos os aspectos do

\footnotetext{
${ }^{143}$ Cf. Bimmel et al. (2011, p. 14-15), "Die Veränderung fachspezifischer Faktoren in den Bereichen Linguistik (z. B. Pragmalinguistik und Lernpsychologie) lässt sich deutlich an den seit Anfang der 1980er Jahre entwickelten kommunikativen Lehrwerken und der wachsenden Vermittlung von Lernstrategien und Lerntechniken in den Lehrwerken der 1990-er Jahre ablesen“.
} 
curso e do processo de ensino-aprendizagem, ou oferecer material para o desenvolvimento de atividades em todos esses âmbitos.

Malgrado essa aparente pretensão, discute-se ainda, na atualidade, a questionável possibilidade de que o LD disponha de todos os insumos necessários para o trabalho em sala de aula (UPHOFF, 2009). Além disso, questiona-se o alcance da aplicabilidade do LD de ALE importado, produzido na Alemanha e consumido, no nosso caso, numa realidade tropical sócio-culturalmente distinta daquela e que é reflexo de outra historicidade. Sobre a adequação do LD a grupos/salas de aula e contextos institucionais específicos, afirmam Bimmel et al. (2011, p. 17-18), dirigindo-se diretamente a professores:

Lehrwerke werden generell für eine Lernstufe [...] erstellt und nicht für eine bestimmte und konkrete Klasse. Lehrwerkautoren schreiben quasi für eine „Phantomgruppe“, sie kennen Ihre Lernenden nicht. Das Vorwissen, die Vorlieben und die Interessen der Lernenden sind aber ein wichtiger Aspekt, der bei der Unterrichtsvorbereitung berücksichtigt werden muss. [...] Die Lehrwerkautoren wissen auch nicht, unter welchen ralen Arbeitsbedingungen das Lehrwerk eingesetzt werden wird. [...] Häufig kennen sie auch die institutionellen Bedingungen nicht. [...] Sie als Lehrende müssen das Lehrwerk also in jedem Fall an Ihre Unterrichtssituation anpassen. $^{144145}$

Uphoff (1999) menciona algumas das questões envolvidas na adoção do LD internacional, tais como sua "concepção genérica" ("não costumam fazer especificações mais rigorosas quanto ao perfil dos aprendizes" - op. cit., p. 7), a ausência de considerações contrastivas quanto às línguas materna e alvo equacionadas no processo de ensino-aprendizagem, e as diferenças entre as culturas educacionais dos países em que se emprega o LD internacional(ista) e a do país de origem do material (e da línguaalvo), entre outras. Com relação à temática do trabalho com questões de ordem cultural

\footnotetext{
144 "Livros didáticos são geralmente produzidos para um estágio específico e não para uma turma concreta e específica. Autores de livros didáticos escrevem quase que para um 'grupo fantasma', eles não conhecem os seus alunos. Os conhecimentos prévios, as predileções e os interesses dos alunos são, porém, um aspecto importante que deve ser considerado durante a preparação das aulas. [...] Os autores de livros didáticos também não sabem sob que condições de trabalho o livro didático será empregado. [...] Com frequência, eles também não conhecem as condições institucionais. [...] Você, como professor, deve adaptar, de todo modo, o livro didático à sua aula."

${ }^{145}$ Em uma perspectiva segundo a qual o professor possa (e até deva) proceder a adaptações e mudanças dos insumos oferecidos pelo LD, Richards (s/d) menciona que o docente pode modificar os conteúdos do livro com vistas a atender às necessidades dos alunos, adicionar ou eliminar conteúdos e tarefas, reorganizá-los e alterar atividades para atribuir-lhes um foco específico.
} 
(Landeskunde), Bimmel et al. (2011) mencionam que o professor precisa buscar materiais extras em outras fontes que não o $\mathrm{LD}$, uma vez que não lhe será possível utilizar e adotar um LD novo e atualizado a cada ano. Assim, é importante que complemente o material adotado com textos de outras fontes atuais, e, acrescento, se possível inserir na aula materiais que tematizem também questões relativas à cultura e língua de partida e à relação dessa cultura com questões concernentes à sociedade da cultura-meta.

Todas essas questões nos levam ao reconhecimento, nos contextos educacionais em que se adotam LDs, do papel do professor como agente crítico e mediador da comunicação entre autor(es) do material empregado e aprendizes, operando modificações de natureza diversa, sempre que julgue necessário e tenha permissão para tal $^{146}$, daquilo que o LD oferece, além de combiná-lo com outros materiais e propostas de ensino, de sua autoria ou de outrem. Assim, em concordância com o que afirma Silva, S. (2012, p. 187),

apesar de não dever ser considerado a única ferramenta no processo ensinoaprendizagem, o livro didático apresenta inúmeras vantagens de uso, no que se refere à organização e sistematização dos conteúdos. Todavia, um dos pontos ressaltados refere-se à necessidade de o professor, [...] especificamente o de língua estrangeira, exercer a criticidade ao escolher e utilizar o livro didático, bem como ao adaptar e incorporar outras ferramentas necessárias ao processo de ensino-aprendizagem de cada grupo, seja em instituição de ensino particular ou pública, cursos de idiomas ou nos níveis fundamental e médio de ensino.

No tocante à relação entre professor e LD, Bimmel et al. (2011) nos lembram que esse profissional representa um fator importante (ou, em minhas palavras, essencial) na preparação das aulas, com suas preferências e desejos e, claro, o conhecimento que detém acerca de seu grupo. Esses autores consideram que LD não é sinônimo de aula, mas sim um material de apoio que deve ser usado com respeito a um plano de aulas e a currículos preexistentes, de acordo com as convicções do próprio professor, com a

\footnotetext{
${ }^{146} \mathrm{Na}$ confecção deste trabalho, parte-se do pressuposto, confirmado pelos depoimentos e informações coletados junto aos professores-voluntários e documentados no apêndice, de que as prescrições institucionais existem e influem no fazer docente. Não se considerarão como pertencendo ao escopo deste trabalho discussões sobre a eventual desobediência às prescrições, uma vez que, ao menos de modo declarado ou consciente, ela não se dá nos contextos observados nesta pesquisa e, assim, não se aplica a esta discussão. Esta investigação tampouco tem como objetivo a transformação das práticas docentes e posturas institucionais, ainda que o debate e as reflexões que este trabalho originou entre pesquisador e professores-voluntários possam indiretamente afetar aspectos de suas futuras práticas.
} 
situação concreta da turma e tendo em vista os alunos que compõem o grupo, de maneira específica, e considerando tanto as características dos grupos (algumas atividades funcionam bem em alguns grupos, dado o seu perfil, e não em outros) quanto as diferenças entre aprendizes dentro de uma mesma turma. Por isso, de acordo com cada grupo, propõem algumas questões que devem ser consideradas pelo docente, a saber:

- Was könnte die Lernenden an diesem Abschnitt interessieren?

- Wo gibt es möglicherweise Probleme?

- Wo kann man an Vorwissen und Vorerfahrungen verknüpfen?

- Was können die Lernenden selbstständig (in Partner-, Gruppenarbeit) erarbeiten?

- Wie kann man den Lernprozess anregen und unterstützen?

- Was müsste man weglassen, was ergänzen? ${ }^{147}$

(BIMMEL et al., 2011, p. 26)

Assim, nenhum livro didático pode, para os estudiosos, ser seguido "página por página"148 (op. cit., p. 20). Bimmel et al. (2011) destacam a existência de LDs de perfil mais aberto, que dão mais claramente espaço para a intervenção do professor, e aqueles de caráter mais fechado, de uso mais difícil, que exigem o seguimento de uma sequência determinada que engessa os movimentos do professor.

Por fim, considero relevante, com base em minha experiência pessoal e profissional e no meu contato com discursos oriundos dos estudos da educação e didática, e aplicando esses conhecimentos à temática do uso do $\mathrm{LD}$, observar que $\mathrm{o}$ emprego desse tipo de material deve estar integrado a uma visão de ensino que priorize a socialização de saberes e fazeres durante a construção de conhecimento por parte dos alunos, a solidariedade entre os membros do grupo e o confronto e aprofundamento de ideias entre eles. Do mesmo modo, deve incluir a valorização da experiência e das crenças dos aprendizes na preparação e condução das aulas, o desenvolvimento e treino da autonomia do alunado, quiçá do que poderíamos denominar uma autonomia colaborativa e, de forma a encapsular capacidades e necessidades próprias do aprendiz

\footnotetext{
147 “O que poderia interessar os aprendizes neste trecho? / Onde há, possivelmente, problemas? / Como se pode estabelecer conexões com conhecimentos e experiências prévias? / O que os aprendizes podem fazer de forma autônoma (em pares e em grupos)? / Como se pode estimular o processo de aprendizagem e darlhe suporte?/ O que se deveria deixar de lado, o que se deveria complementar?"

${ }^{148}$ No original, "Seite für Seite".
} 
adulto, o estímulo à metacognição ${ }^{149}$, ao pensar sobre o pensar, sobre o aprender e sobre o sentir. Assim, o movimento aluno-professor-conhecimento mediante o emprego do livro didático se dinamiza e alinha com propostas contemporâneas e, creio, eficazes de ensino-aprendizagem.

$\mathrm{Na}$ segunda parte do trabalho ("Materiais e Métodos"), bem como na documentação contida no apêndice, pretende-se verificar sob que circunstâncias e de que forma se perfila o uso que fazem os professores-voluntários de nossa pesquisa do LD que estão institucionalmente obrigados a adotar em seu curso. Na parte dedicada a esta temática no capítulo 2 desta dissertação, será estabelecido um contraponto entre os fundamentos teóricos ora apresentados e a realidade educativa e institucional em que se inserem suas práticas e das quais promanam os dados coletados durante suas aulas.

\footnotetext{
${ }^{149}$ Não se quer dizer, com isso, que a criança não seja capaz de metacognição, mas o maior repertório de experiências e o desenvolvimento psicoemocional do adulto são especialmente convidativos para que se desenvolva e treine a metacognição, com grandes benefícios para o aprendiz. Dadas as características do experimento empírico em torno do qual se articula este trabalho, não se enfocarão, aqui, características e métodos de ensino de ALE para crianças e adolescentes.
} 
3. MATERIAIS E MÉTODOS 


\title{
3.1 Aspectos metodológicos ${ }^{150}$
}

Neste capítulo, objetiva-se:

1. Definir o contexto da pesquisa ${ }^{151}$ (paradigma de pesquisa, local de trabalho, instituições de ensino, os cursos, os participantes, o pesquisador, os professores-voluntários e os alunos, critérios de credibilidade);

2. Explanar sobre a coleta de dados (tempo, etapas, procedimentos, seleção, aplicação dos exercícios, correção e tabulação);

3. Apresentar os materiais (excertos dos LDs) utilizados na pesquisa, explicitar a tipologia de exercícios adotada e justificar sua escolha.

Esses temas serão tratados a seguir.

\subsubsection{Paradigma, classificação e metodologia da pesquisa}

\begin{abstract}
$\mathrm{Na}$ era do caos, do indeterminismo e da incerteza, os métodos científicos andam com seu prestígio abalado. Apesar da sua reconhecida importância, hoje, mais do que nunca, se percebe que a ciência não é fruto de um roteiro de criação totalmente previsível. Portanto, não há apenas uma maneira de raciocínio capaz de dar conta do complexo mundo das investigações científicas. (MORESI, 2003, p. 26)

Todo instrumento ou procedimento de pesquisa encontra-se inextricavelmente permeado de compromissos para com versões particulares do mundo e modos de conhecimento do mundo adotados pelo pesquisador que os utiliza. (HUGUES apud DE GRANDE, 2011, p. 12) ${ }^{152}$.
\end{abstract}

Esta pesquisa ostenta um perfil aplicado, uma vez que "objetiva gerar conhecimentos para aplicação prática dirigidos à solução de problemas específicos [e] envolve verdades e interesses locais" (MORESI, 2003, p. 8), pretendendo-se que as reflexões e resultados aqui propostos sejam de serventia para outros pesquisadores e professores interessados nas temáticas implicadas na investigação. O paradigma de

${ }^{152}$ A autora cita HUGHES, J. A filosofia da pesquisa social. Rio de Janeiro: Zahar Editores, 1983. 
pesquisa é híbrido, uma vez que se mesclam características da pesquisa quantitativa (informações serão traduzidas em números e comparadas estatisticamente) com outras próprias da pesquisa qualitativa, com fenômenos sendo interpretados e com significados sendo atribuídos aos registros e resultados, considerando-se a complexidade do objeto de pesquisa, "uma vez que, resguardando-se as especificidades, é evidente a complementaridade entre ambos [os paradigmas]" (BAZARIM, 2008, p. 98). Como é próprio da pesquisa qualitativa (BAZARIM, 2008), trabalha-se indutivamente, dos dados para a teoria; porém, existe igualmente um movimento (próprio do paradigma quantitativo) da teoria para os dados (método dedutivo) e uma busca de explicações para os fenômenos encontrados durante a análise (método abdutivo) ${ }^{153}$. Hipóteses iniciais serão confirmadas ou refutadas a partir da análise dos dados, mas os dados também servirão para a elaboração de eventuais novas hipóteses, explicadas abdutivamente. Como afirma Celani, comparando os paradigmas quantitativo e qualitativo de pesquisa em LA,

embora objetivos e valores fundamentais sejam realizados de maneiras diferentes, ambos os paradigmas se preocupam com a produção de conhecimento, com a compreensão dos significados, com a qualidade dos dados; ambos os paradigmas têm por valores fundamentais a confiança, a responsabilidade, a veracidade, a qualidade, a honestidade e a respeitabilidade e não a busca da riqueza ou do poder. (CELANI, 2005, p. 106)

Interpola-se ainda, nesta investigação, o elemento etnográfico, já que

os propósitos essenciais da etnografia são documentar em detalhe o desenrolar de um evento que seja cotidiano para os participantes, bem como identificar os significados atribuídos a esse evento tanto por aqueles que participaram, quanto por aqueles que observaram. A ênfase da pesquisa passa a ser, portanto, as interpretações dos participantes, as quais são consideradas de maneira crítica pelo pesquisador (BAZARIM, 2008, p. 99).

No caso, os professores-voluntários também participam da atribuição de significados a todo o processo.

Com relação às finalidades, a pesquisa é de cunho explicativo, ao buscar justificativas e motivos para os fenômenos abordados. Possui características de pesquisa de campo, já que "é investigação empírica realizada no local onde ocorre ou ocorreu [o]

${ }^{153}$ Ver Santaella (2001). 
fenômeno ou que dispõe de elementos para explicá-lo" (MORESI, 2003, p. 9), de pesquisa bibliográfica, uma vez que se revisam os principais fluxos discursivos correntes nas áreas diretamente abarcadas ou tangidas pelo trabalho, ex post facto e de estudo de caso (cf. MORESI, 2003).

\subsubsection{Contexto da pesquisa}

Por contexto da pesquisa, entendam-se todas as informações relevantes à sua contextualização e à ulterior validação dos dados coletados. São de interesse, nesta etapa, as instituições de ensino (escopo, características, perfil...), os cursos específicos

onde se ministraram os conteúdos e aplicaram os testes (docentes, alunado...) e informações sobre o pesquisador. As instituições de ensino consistem no primeiro tema a ser circunscrito nesta parte da dissertação.

\subsubsection{Instituições de ensino}

Como afirmado anteriormente, os testes foram realizados em duas instituições de ensino, devido à necessidade de encontrar escolas nas que se adotassem livros didáticos diferentes, onde a apresentação de insumos gramaticais se desse de acordo com as duas abordagens exploradas no capítulo 1.3 de pressupostos teóricos.

A primeira delas, e a que será tratada neste trabalho, é uma instituição sem fins lucrativos, de propriedade do Ministério das Relações Exteriores da República Federal da Alemanha, cuja cultura representa ao redor do mundo. No Brasil, está presente em seis grandes centros urbanos: São Paulo, Rio de Janeiro, Curitiba, Porto Alegre, Salvador e Brasília; na Alemanha, onde se localiza a sede em Munique, e ao redor do mundo, contabilizam-se dezenas de unidades, em todos os continentes.

A estrutura administrativa da filial paulistana ostenta três pilares básicos: um departamento de língua, através do qual são oferecidos cursos de alemão como língua 
estrangeira, um departamento de difusão cultural, que promove eventos que interrelacionam Brasil e Alemanha e, por fim, a manutenção de uma biblioteca com um acervo atualizado sobre assuntos germanísticos e de intersecção temática BrasilAlemanha. Por fim, a escola de São Paulo, centro administrativo das unidades sulamericanas da instituição, possui um departamento de colaboração pedagógica, oferecendo cursos de formação e especialização para seus docentes e para os de outras escolas, principalmente dos CEL (Centros de Estudos de Línguas) do governo estadual paulista.

Com aproximadamente 1000 - 1200 novas matrículas por semestre, num ritmo que se pode considerar estável ou inclusive de aumento discreto e contínuo de demanda ${ }^{154}$, essa escola de alemão é a maior do país. Sua proposta pedagógica é de índole construtivista, sócio-interacionista e pós-comunicativa ${ }^{155}$. É esperado dos docentes que baseiem o núcleo de suas aulas em torno do "uso inteligente" das propostas do livro didático adotado para cada estágio ${ }^{156}$ (studio $d$ para os níveis A1, A2 e B1 do Quadro Europeu Comum de Referência, Ziel para os níveis B2 e C1 e Auf neuen Wegen para os cursos C2) .

O perfil dos alunos, de forma geral, é homogêneo: a faixa etária se situa entre os 25 e 35 anos, havendo, obviamente, um bom número de casos de pessoas que se encontram aquém ou além desses limites. Quanto à classe social, trata-se de um grupo de jovens abastados, pertencentes, de modo majoritário, às classes $\mathrm{A}$ e $\mathrm{B}$ e com alto nível de escolaridade ${ }^{157}$. Destaca-se a presença massiva de alunos que se graduaram nas melhores universidades da região e não poucos casos de pós-graduados e pósgraduandos.

O professorado da escola, composto por cerca de 30 profissionais, possui, em

\footnotetext{
${ }^{154}$ Informação fornecida pela secretaria da escola.

155 Entende-se aqui por pós-comunicativa a fase atual do ensino-aprendizagem de LE em que preponderam os princípios básicos da abordagem comunicativa, havendo, porém, a liberdade nãodogmática e "pós-era-dos-métodos" de combinar recursos didático-pedagógicos de diferentes métodos e abordagens na idealização e prática de uma aula contundente.

${ }^{156}$ Conforme declaração do professor-voluntário documentada no apêndice.

${ }^{157}$ Informações oferecidas pelos professores da escola. Verifique-se anexo.
} 
sua maioria, bacharelado em Letras com a habilitação alemão, obtida majoritariamente na USP, UFRJ ou na UNESP de Araraquara. Aproximadamente um terço desses profissionais é também licenciado em alemão. Conta-se, ainda, com alguns casos de mestres na área e, no caso dos docentes não diplomados em Letras, a escola lhes ofereceu um curso de formação de professores de duração de um ano (agora reduzida) que cobre todos os principais aspectos didático-metodológicos aplicados à área de alemão LE, incluindo observação frequente de aulas e team teaching com colegas do curso de capacitação e professores mais experientes, os tutores. A escola está envolvida, também, numa parceria com a Universidade Federal da Bahia e a Universidade de Kassel, na Alemanha, que resulta na realização de um curso de especialização intitulado "Ensino de Alemão para Professores de Alemão".

A natureza desta pesquisa, como já foi afirmado, exigia a aplicação dos testes em duas instituições onde se utilizassem diferentes livros didáticos com propostas discordantes de progressão da gramática. Ajudaria muito, pois, que ambas as instituições fossem parecidas em sua natureza, propostas, prescrições, dimensões, público-alvo, corpo docente, entre outros fatores, de modo a optimizar a comparabilidade dos dados. Todavia, dado o tamanho da primeira (supracitada) instituição (uma das poucas a utilizarem studio $d$ ), faz-se impossível competir com suas dimensões e seu alcance na sociedade enquanto centro de referência. Optou-se, por esse motivo, em focar no perfil dos alunos e professores, critério fundamental para que se possa proceder à comparação entre os dois centros, e elegeu-se, assim, uma escola de médio porte situada dentro do campus de uma grande universidade paulista, embora sem vínculo direto com ela, onde se adota Schritte International como LD para os cursos entre os níveis A1 e B1 do QECR. A escola pertence, de fato, ao centro acadêmico da faculdade em que se encontra.

Atuando na área de ensino de línguas desde 1989, nessa segunda escola lecionam-se, além do alemão, aulas de inglês, espanhol, italiano e francês. O número de matrículas dos cursos de alemão nessa instituição é consideravelmente menor que o da anterior. Nos últimos dois anos, a escola registrou 256 matrículas de alunos para os cursos de alemão dos diferentes níveis oferecidos (A1 a C1 do QECR), resultando em uma média de 60 matrículas por semestre. O professorado da escola, constituído de seis profissionais, é em sua maioria formado em Letras pela Universidade de São Paulo, 
com habilitação em Alemão, e, como atesta a página web da escola, "são nativos ou brasileiros, todos com formação acadêmica nas melhores universidades alemãs e brasileiras, boa parte tem o DLA - Deutschlehrerausbildung, programa especial de formação de professores, organizado pelo Instituto Goethe de todo o mundo em convênio com a Universidade de Munique" ${ }^{\text {,158. }}$

O fato de "boa parte" dos professores dessa instituição terem feito o DLA foi um dos critérios que nos levaram à sua escolha para conduzir parte da pesquisa, uma vez que isso aproxima consideravelmente os fazeres didáticos registrados em ambas as escolas, o que inclui a adoção da tipologia de exercícios de Neuner et al. (1981), associada ou não a outras, quando da condução das aulas e na seleção de exercícios a serem aplicados após o trabalho com um tópico gramatical novo ou revisado, seja ele advindo do LD adotado ou de materiais extras empregados ou criados pelos professores.

\subsubsection{Os cursos}

Os cursos em questão correspondem ao final do estágio A2 do Quadro Europeu Comum de Referência para o ensino-aprendizagem de línguas estrangeiras, adotandose, como mencionado, o livro didático studio d A2, e ao início do nível B1, adotando-se, nesse caso, o LD Schritte International 5. Mais especificamente, trata-se dos cursos A2.2 (antigo básico 4), o segundo na subdivisão binária do nível A2, e B1, antigo intermediário 1 nessa instituição. Neste ponto, o aluno ainda aprende a comunicar-se em situações cotidianas, porém rumando à construção de uma maior autonomia no uso da língua, aprendendo, à guisa de exemplo, a expressar e justificar opiniões e a descrever situações e fatos, mesmo que de maneira ainda pouco sofisticada e com moderado grau de correção gramatical. Realizou-se, no caso das duas turmas, das $18 \mathrm{~h} 45$ às $22 \mathrm{~h}$, uma turma às terças e quintas e a outra às segundas e quartas-feiras.

O curso no qual se adota studio $d$ se baseia no trabalho com as cinco últimas das dez lições de que se compõe o livro, pertencendo a abordagem da temática das orações

\footnotetext{
${ }^{158}$ Informação disponível na página web da instituição, cujo nome será mantido em sigilo.
} 
relativas à última unidade. No outro curso, em que se emprega Schritte, são abordadas as cinco primeiras lições do volume. A cada duas lições, nas duas escolas, os alunos passam por uma prova de conhecimentos gramaticais (em alguns cursos, também de vocabulário) com cerca de cinco exercícios breves de completar lacunas, marcar verdadeiro ou falso, dar continuidade a fragmentos de sentenças ou ordenar elementos de uma frase ${ }^{159}$. Ao final do curso, realiza-se uma avaliação final mais ampla, abarcando as cinco lições, onde se incluem exercícios de leitura e interpretação de texto (com exercícios de múltipla escolha), de compreensão auditiva (marcar verdadeiro ou falso) e a escritura de uma redação, com estrutura inspirada nos exames oficiais de proficiência do Instituto Goethe. Na instituição que adota studio $d$, também é feita uma prova oral nos moldes do exame oficial de proficiência Start Deutsch 2 (apresentar-se, formular e responder perguntas, reagir a estímulos visuais). Na outra, existe a atribuição de uma nota correspondente à produção oral dos aprendizes, assim como observada e avaliada pelo professor ao longo do semestre.

As aulas seguem, em ambas as escolas, os preceitos da abordagem comunicativa (AC) mesclados a perspectivas próprias da era pós-método ou, como querem alguns, pós-comunicativa, em um trabalho pouco dogmático com as propostas da $\mathrm{AC}$, ou seja, os professores têm a liberdade de integrar aos seus cursos atividades eventuais calcadas em preceitos de outras abordagens ou métodos, desde que seu uso seja pedagogicamente justificável dentro das condições, características e necessidades de cada grupo e sirva de apoio às atividades do livro.

\subsection{Participantes (alunos) ${ }^{160}$}

Aos alunos foi facultada a participação ou não na pesquisa, conforme constava do texto do termo de consentimento livre e esclarecido por eles assinado. Nos dois grupos em que se passaram os questionários, a participação dos alunos foi massiva

\footnotetext{
${ }^{159}$ Correspondendo, assim, grosso modo, aos exercícios mais reprodutivos da tipologia de Neuner et al. (1981).

${ }^{160}$ As informações são oriundas de um questionário respondido pelos informantes e documentado no anexo.
} 
(excetuando-se os que faltaram) e entusiasmada. Nas palavras de um dos professoresvoluntários (literalmente), "eles se sentiram muito especiais ao colaborar com uma pesquisa de mestrado". A outra professora-voluntária ressaltou o interesse de seus alunos nos exercícios, que encararam como "oportunidade de treinar mais"

Nos dois grupos houve seis participantes presentes durante a aula em que foram aplicados os exercícios (uma das turmas compunha-se de apenas seis alunos; na outra, estavam matriculados oito, mas apenas seis compareceram a essa aula). Embora os testes tenham sido anônimos, pediu-se aos alunos que indicassem alguns dados pessoais (idade, profissão e experiência com o idioma). Tem-se, no grupo que trabalha com studio $d$, participantes de 18 a 31 anos, entre eles professora, estudantes, médico e advogada. Todos os alunos se encontram atualmente no nível A2.2 (o segundo curso de uma subdivisão do nível A2 do QCER em dois estágios praticada pela escola) e frequentaram os cursos/estágios anteriores na mesma instituição (A1.1, A1.2, A1.3 e A2.1), não tendo estudado alemão em outra instituição e tendo adquirido seus conhecimentos iniciais da língua no curso A1.1 desta mesma escola, ou seja, eram totalmente iniciantes quando ingressaram no primeiro curso. A turma sofreu algumas alterações em sua composição ao longo dos semestres, com a saída de alguns alunos e a entrada de outros devido a trocas de horários.

No caso do grupo que estuda com Schritte International, computou-se a participação de seis informantes, de entre 17 e 28 anos, cinco deles estudantes de diversas unidades de uma grande universidade paulista e uma secretária não vinculada a essa IES. Esses alunos tampouco dispunham de pré-conhecimentos acerca do idioma. Todos frequentaram os estágios anteriores na escola, à exceção da aluna secretária, que fez um semestre de aulas particulares (o equivalente ao nível A1.1) e os demais cursos (A1.2, A2.1, A2.2) nessa mesma instituição. A turma se manteve homogênea ao longo dos semestres. Tendo verbalizado esse objetivo de diferentes formas, praticamente todos declaram almejar adquirir proficiência em língua alemã para a comunicação quotidiana, oral e escrita, com três menções, em um grupo, ao desejo de melhorar ou ampliar o currículo. No grupo dos cinco estudantes (Schritte), a secretária declarou necessitar do alemão para a vida profissional. No outro grupo, de studio $d$, a advogada declarou ter

${ }^{161}$ Vide entrevistas no apêndice. 
interesse no direito alemão como base do direito brasileiro, mas não apontou a necessidade acadêmica ou profissional de dominar o alemão. A opção "hobby ou gosto por aprender línguas" foi assinalada por um informante do grupo de Schritte, que especificou ter obtido uma bolsa para estudar alemão na instituição.

\subsection{Professores-voluntários}

A participação dos professores-voluntários na pesquisa deu-se de forma fluída. Ambos se prontificaram a colaborar e demonstraram grande interesse em compreender o projeto, os exercícios e os objetivos.

O primeiro professor trabalha na instituição há cerca de dois anos e, antes de ser contratado, era colaborador da filial da escola em outra capital brasileira. Possui graduação em Letras, curso de formação de professores de alemão e especialização em ensino de alemão LE. Atuando na função de professor de alemão desde 2004, ele conta com dez anos de experiência profissional na área. A segunda professora, na escola há nove anos, tem suas origens em outra capital brasileira, onde trabalhou em diversas escolas de alemão e bacharelou-se em Letras/Alemão numa universidade federal. Possui em seu currículo dois cursos extensivos de formação de professores de alemão. Conta com dezenove anos de experiência no ensino de alemão como $\mathrm{LE}^{162}$. Ambos os professores participaram de diversos seminários de atualização pedagógica na Alemanha, onde tiveram estadias de duração moderada. Nos dois casos, não se deu uma residência em um país de língua alemã por um período superior a três meses ${ }^{163}$.

\footnotetext{
${ }^{162}$ Dado de 2014.

${ }^{163}$ Informações cedidas pelos professores por e-mail.
} 


\subsection{Pesquisador}

Bacharel desde 2002 e licenciado em Letras (Alemão), atuo como professor desta LE desde 1998, quando ainda me encontrava no segundo ano do bacharelado. Desde então, atuei como docente em diversas escolas, incluindo-se as duas instituições nas quais se conduziu o experimento empírico desta pesquisa. Com estudos de Germanística (incluindo-se um módulo de Didática de LE) na Alemanha e de Estudos Interculturais e Tradução na Espanha, passei a dedicar-me a interesses acadêmicos em contexto brasileiro desde 2011. A partir de então, perseguindo meu interesse na carreira, iniciei o curso de Mestrado, publiquei alguns artigos sobre ensino-aprendizagem de gramática (entre outros temas) e apresentei trabalhos em congressos, encontros e outros eventos, locais, regionais, nacionais e internacionais.

\subsection{Procedimentos de coleta de dados}

A coleta de dados se deu através da proposta dos exercícios aos alunos por parte dos professores. Em outras palavras, os exercícios foram aplicados em sala de aula a título de atividade de fixação, imediatamente após a apresentação do tema gramatical (orações relativas), não diferindo de uma lista de exercícios comum. A coleta realizouse, portanto, em apenas um dia, i.e., durante apenas uma aula.

Antes da coleta dos dados que foram efetivamente analisados no capítulo 3 deste trabalho, procedeu-se a uma pilotagem da lista de exercícios junto a um grupo de aprendizes que, incialmente, era composto por 8 pessoas, embora apenas 4 tenham comparecido no dia da aplicação dos testes. Os resultados da pilotagem demonstraram que os alunos entenderam as questões e que os exercícios funcionavam, podendo ser, por isso, aplicados de forma definitiva. Entretanto, observou-se a necessidade de solicitar aos professores que realizariam a aplicação dos exercícios que explicassem aos alunos, antes de distribuírem os testes, o significado da palavra "Roman" (romance), visto que, aparentemente, os aprendizes interpretaram seu sentido como sendo 
"romano". Os professores-voluntários que aplicaram os testes analisados nesta pesquisa afirmam terem elucidado o sentido desse vocábulo antes de que os alunos efetuassem as atividades, embora os dados demonstrem que a confusão Roman/romano se repetiu ${ }^{164}$. Os dados da pilotagem não serão computados nesta dissertação, uma vez que o piloto apenas serviu para testar os exercícios, e o quórum de participantes foi baixo, ainda mais baixo que o das turmas em que se realizou a coleta definitiva dos dados (6 membros em cada uma). Uma vez que o piloto tinha como único objetivo verificar se os alunos entendiam as questões, ele foi aplicado a apenas uma turma (que trabalhava com studio $d$ ), de modo que esses dados não poderiam ser aproveitados na análise final, devido ao número inferior de informantes em relação ao grupo de sujeitos que estudavam com Schritte International. Quanto à questão do vocábulo "Roman", esperava-se que sua aparição não gerasse problemas no grupo de Schritte, já que essa palavra aparece no livro algumas páginas antes do tratamento das orações relativas, na mesma lição (o que será mencionado e discutido junto à análise dos dados desse grupo no capítulo 3), e considerando-se que a professora desse grupo afirma ter utilizado em sala, poucas aulas antes da coleta, a página do livro em que o vocábulo aparecia.

As etapas da coleta definitiva de dados foram: 1) a solicitação aos professoresvoluntários de sua participação na pesquisa; nesse processo, até que se encontrassem os dois colaboradores desta pesquisa, deu-se uma ausência de resposta (professora não respondeu e-mail solicitando participação) - julho de 1012; 2) encontros com os professores para explicar-lhes a proposta e objetivos do projeto, a lista de exercícios, os procedimentos a seguir etc. - agosto de 2012 e fevereiro de 2013; 3) a aplicação dos exercícios em aula por parte dos professores-voluntários - novembro de 2012 e abril de 2013; 4) realização das entrevistas com os professores - primeiro semestre de 2013 . No relatório de qualificação, já estavam incluídos a lista de exercícios e um esboço preliminar da proposta de análise dos dados.

\footnotetext{
${ }^{164}$ Mais a respeito durante a análise dos dados no capítulo 3.
} 


\subsubsection{Os exercícios}

As atividades propostas na lista de atividades aplicada seguiram a tipologia de Neuner et al. (1981), a ser tematizada no próximo item, de acordo com sua escala de progressão de exercícios. A lista inclui uma atividade A (ligar orações principais a orações relativas de acordo com as informações de um texto), uma B (completar sentenças com pronome relativo ora apresentado, ora não), uma C (completar fragmentos de sentenças apresentados sem os pronomes relativos) e uma de tipo D (escrever um texto de temática livre incluindo orações relativas ${ }^{165}$ ). Verifique-se a lista no apêndice 2.

\subsubsection{Tipologia de exercícios de Neuner et al. (1981)}

Quer se vise à análise das atividades propostas pelos autores de studio $d \mathrm{e}$ Schritte International para o treino das estruturas a ensinar e aprender, quer se objetive a elaboração dos exercícios a serem aplicados aos participantes voluntários da pesquisa, a tipologia de exercícios de Neuner et al. (1981) mostra ser, no meu juízo, a mais apta na busca de respostas às minhas perguntas de pesquisa. Isso se deve ao fato de tal tipologia de exercícios corresponder aos preceitos da abordagem comunicativa, que norteia os cursos de ambas as instituições e se emprega em manuais de ampla utilização tradicionalmente adotados na formação de professores de alemão LE (p. ex. FUNK; KOENIG, 1991) que influencia o trabalho pedagógico nas duas escolas e que é difundida na supramencionada Deutschlehrerausbildung, da qual fizeram parte ambos os professores-voluntários. Além disso, durante os depoimentos registrados no apêndice deste trabalho, os professores-voluntários afirmaram trabalhar com a tipologia de exercícios supracitada.

\footnotetext{
165 Para a elaboração desse exercício, discutiu-se com os professores-voluntários o tipo de produção textual que eles costumavam propor aos seus alunos quando desejavam incitar a aplicação de alguma estrutura gramatical nesse texto. Verifiquem-se depoimentos no apêndice.
} 
De acordo com os professores, após a explicitação e conscientização (Bewusstmachung) acerca do funcionamento de um determinado tópico gramatical, eles propõem aos alunos exercícios dos tipos A, B, C e D, de forma a possibilitar seu treino e ofertar, assim, atividades que visem a viabilizar sua assimilação. O motivo do emprego dessa tipologia de exercícios por parte dos professores seria o fato de terem recebido treinamentos, em suas instituições de origem e no Goethe-Institut São Paulo, nos quais se propunha essa tipologia de exercícios como aquela que deveria ser ativada em suas aulas ${ }^{166}$. Considera-se, assim, que é relevante apresentar aos alunos informantes desta pesquisa uma lista de exercícios que lhes seja familiar em seu feitio e estrutura, de modo que os exercícios propostos correspondam ao tipo de exercícios que já fariam, de todos os modos, nas aulas em que se aplicaram os testes. Além disso, a tipologia de Neuner et al. (1981) atende às exigências de aulas comunicativas de ALE. Por fim, é importante salientar o fato de que, como expresso na lista de objetivos elencados na introdução deste trabalho, desejam-se investigar as diferenças observadas na produção escrita de alunos em atividades mais e menos (re)produtivas, de modo a que verifiquemos se existem diferenças entre seu rendimento em exercícios mais controlados e de automatização e aqueles mais livres, nos quais se espera que construam suas próprias frases por completo e seus contextos de aparição ${ }^{167}$. O interesse nessa questão advém de meus conhecimentos de mundo e intuições, bem como de minha experiência profissional com ensino de ALE, durante a qual observei a maior facilidade que os alunos demonstram ter ao realizar exercícios reprodutivos $\mathrm{e}$ as (comparativamente maiores) dificuldades que se manifestam quando se lhes propõe criar discurso na língua estrangeira. Entretanto, não disponho de dados concretos e verificáveis para sustentar essa impressão, lacuna que esta pesquisa pretende ajudar a preencher.

\footnotetext{
${ }^{166}$ Segundo os informantes (verifique-se apândice), a tipologia de Neuner et al. (1981) é proposta como aquela a ser adotada nas aulas, mas a combinação de outras tipologias comunicativas de exercícios não é desencorajada nem proibida. Entretanto, uma vez que os professores adotam a tipologia de Neuner em suas aulas e não declaram adotar de forma intencional ou consciente as outras tipologias, mantivemos, por questões de coerência e pelo fato de o alunado estar acostumado a esse tipo de exercícios, uma lista de atividades compatível com aquelas que os professores já ofertariam aos alunos nas aulas em que se deu a coleta de dados.

167 A escala de Neuner et al. (1981) também é bastante semelhante à sequência rezeptiv rezeptiv/produktiv - produktiv adotada em Funk; König (1991), Fernstudieneinheit amplamente utilizada em cursos de formação de professores de ALE no Brasil (e que também referenda NEUNER et al., 1981), como a Deutschlehrerausbildung do Goethe-Institut e a Especialização em "Ensino de Alemão para Professores de Alemão" da UFBA/UniKASSEL. Sobre a influência das Fernstudieneinheiten na área de ALE, verifique-se Uphoff (2011).
} 
Estou ciente, a despeito dessa decisão, da existência de outras tipologias de exercícios influentes em nossa área de atuação ( $D a F)$, como as de Rampillon (2000) e a de Häussermann; Piepho (1996). A primeira dessas tipologias leva em consideração, sobremaneira, as questões da aprendizagem autônoma e do desenvolvimento consciente de técnicas que a viabilizem. Visa-se a uma aprendizagem autocontrolada e ao trabalho com técnicas de aprendizagem. Entre os tipos de exercícios da segunda tipologia suprerreferida, encontram-se, além da ênfase na conscientização acerca do processo de ensino-aprendizagem e sua facilitação, vários que não se aplicam aos propósitos do trabalho explícito com estruturas gramaticais, como a sensibilização da audição, reconhecimento de sons e sotaques, de nuances linguísticas, desenvolvimento de competência intercultural, diferenciação do vocabulário, desenvolvimento de uma inteligência de leitura, aprendizagem intercultural, realização linguística de forma oral etc $^{168}$. Embora julgue essencial a inserção de atividades desse naipe em cursos (pós-) comunicativos de ALE, considero que a realização de exercícios gramaticais com vistas, especificamente, à verificação do aprendizado da estrutura Relativsätze não consista no ensejo mais apto para o treino de autonomia e técnicas de aprendizagem autocontrolada. Não é esse o foco nem o escopo da investigação. Cabe aos professores, ao longo do curso e nos momentos em que o julgarem possível e adequado, propor atividades que visem ao desenvolvimento dessas competências tão importantes e que possam ser aplicadas à realização não apenas de exercícios de ALE, mas em diversos momentos nos quais o aprendiz se depara com a necessidade de resolução de problemas e, como um todo, de aprendizagem na vida quotidiana. Além disso, vale ressaltar que as propostas de Rampillon (2010) e Häussermann; Piepho (1996) são combináveis, caso o docente o deseje, com a de Neuner et al. (1981), uma vez que focam aspectos distintos do processo de ensino-aprendizagem e não são excludentes. Ou seja, sua adoção, nos casos em que ocorra, não impede o emprego da tipologia de que me vali durante a criação da lista de exercícios, ainda que, como há pouco afirmei, o contexto desta pesquisa não me pareça o mais adequado para sua inclusão. ${ }^{169}$ É fundamental relembrar

\footnotetext{
168 Algumas propostas dos autores, como reconhecer e marcar elementos estruturais num texto e o estímulo à formulação de regras condizem com o trabalho dos professores-voluntários e com a proposta dos LDs, mas considero que a coleta de dados tampouco era o ensejo adequado para a realização desse tipo de exercícios.

${ }^{169}$ Cunha (2013) demonstra que as vicissitudes das tipologias de Rampillon e Piepho; Häussermann se encontram nas propostas de exercícios de studio $d$, e quantifica a incidência de cada tipo, em três lições específicas dos volumes A1 e B1, em porcentagens. No caso desta pesquisa, os depoimentos dos
} 
que uma das perguntas de pesquisa e objetivos deste trabalho consistia em observar o desempenho dos alunos em atividades mais e menos (re)produtivas, algo que a tipologia de Neuner et al. (1981) nos permite contemplar com bastante clareza.

Esses autores nos lembram que a apresentação e o trabalho com os diversos temas e conteúdos em aula de LE variaram sobremaneira ao longo do tempo e quando da dominância de cada método ou abordagem, e variam inclusive de um livro didático para outro. Durante a atual preponderância da abordagem comunicativa ${ }^{170}$, o autor distingue quatro etapas do trabalho com textos (em acepção ampla, verbais ou não) da LE, ao passo em que se buscam autonomia e competência comunicativa. Trata-se dos exercícios de tipo A, B, C e D, a saber, os receptivos, os reprodutivos, os reprodutivoprodutivos e os produtivos. Normalmente, os exercícios são propostos nessa sequência, podendo, contudo, haver mais de uma fase seguida do mesmo tipo de atividade e uma alternância de etapas, de acordo com a necessidade do grupo identificada pelo docente.

A. Em primeiro lugar, trata-se do trabalho de "desenvolvimento da habilidade de compreensão" (1981, p. 20), fase durante a qual o estudante necessita ajuda para entender as informações principais do texto e comprovar essa compreensão. Os exercícios pertencentes a esta categoria são de natureza mecânico-reprodutiva e não têm como objetivo a expressão da criatividade. Este grupo está composto por atividades de distinção entre certo e errado, seleção de respostas entre várias alternativas, textos com lacunas a serem preenchidas, grifar trechos de textos, localizar palavras-chave, ligar frases etc.;

professores e minha análise desse material, bem como de Schritte International, demonstra que ambos os manuais também oferecem atividades que se enquadram nas categorias de Neuner et al. (1981).

${ }^{170}$ No atual período denominado "pós-método" (conceituação cf. KUMARAVADIVELU, 2006e 2006a; SILVA, 2008, BORGES, 2010), marcado pelo "ecletismo esclarecido" (BROWN apud SILVA, 2008), ainda que Kumaravadivelu o criticasse (cf. SILVA, 2008), e pela não-adoção acrítica e total das propostas de um único método ou abordagem, considera-se que o professor tem a liberdade de acionar recursos pedagógicos advindos também de métodos e abordagens mais antigos, assim como o fazem os LDs contemporâneos de ALE. Nessa perspectiva, afirma SILVA (2008, s/n), “o papel do(a) professor(a) não se resume a selecionar conteúdo e escolher técnicas para aplicá-los, ele também pode possibilitar que os aprendizes reflitam sobre seu papel na sociedade, como a linguagem está estruturada e a que interesses ela serve". Apesar disso, e mesmo que se fale em "fase pós-comunicativa", nas instituições em que se realizou a coleta de dados, a abordagem comunicativa ainda consiste no principal esteio teóricometodológico que norteia as aulas. Verificar declarações dos informantes no apêndice. 
B. O segundo tipo consiste em colocar à disposição do aluno meios linguísticos necessários para sua expressão, por meio de exercícios ainda guiados, visando à organização das formas da língua, incluindo-se a morfossintaxe. Formam parte deste tipo tarefas como jogos para a ativação do vocabulário e estruturas, atividades de laboratório etc.;

C. Estes exercícios rumam em direção a uma maior autonomia e criatividade, sendo, porém, parcialmente guiados, mesmo que menos que os anteriores. É variável o grau de criatividade permitido por exercícios deste tipo, podendo pender mais na direção dos exercícios (B) ou mais na dos (D), dependendo da intervenção e influência do professor. Dedicam-se ao emprego de meios linguísticos e informações de conteúdo, incluindo-se fazer apontamentos, utilizar o dicionário, recriar um texto com mudança de gênero, diálogos abertos e, no campo da gramática, completar sentenças etc.;

D. Neste patamar, trata-se da chegada ao nível das atividades produtivas, através da realização simulada de atos de fala, dependendo dos resultados do trabalho com as fases A, B e C. Aqui, o aluno conta histórias, participa de discussões, argumenta, encena, produz textos escritos.

É fundamental sublinhar, no caso dos exercícios de tipo D, que sua aplicação em cursos relativiza, por si só, seu perfil "puramente" produtivo. Isso porque toda a produção de sala de aula é determinada por impulsos dados pelo professor e/ou pelo livro didático, quando adotado, não surgindo, de forma geral, do desejo autêntico e nãoinfluenciado dos estudantes de autoexpressar-se. $\mathrm{O}$ ato de elaborar uma redação atende à definição de temas pelo professor ou pelo livro, um diálogo livre responde à mesma proposta etc. Trata-se, portanto, do máximo que se pode fazer no contexto de cursos de LE para aproximar-se da fluência na produção textual (de qualquer tipo). 


\subsection{Os livros didáticos}

Neste subcapítulo, pretende-se apresentar ao leitor os excertos dos livros didáticos studio $d A 2^{171}$ e Schritte International $5^{172}$ implicados na lista de exercícios proposta aos alunos-informantes e constituintes, assim, do objeto empírico desta pesquisa. As páginas dos LDs a que se fará alusão encontram-se reproduzidas no anexo, ao final do trabalho. Trata-se das partes específicas desses livros que apresentam as Relativsätze aos aprendizes. No caso de studio $d$, será feita referência também à lição antecedente em que as orações relativas no nominativo e acusativo foram introduzidas. Isso se deve ao caráter sintético do ensino-aprendizagem da estrutura com esse LD, de forma a que a apresentação das relativas no dativo necessariamente implique a referência (que o manual sugere explicitamente) a essa lição anterior. O professorvoluntário da pesquisa com studio $d$ declara ter feito essa referência explícita em sala de aula (documentação no apêndice) ${ }^{173}$. O texto assumirá uma característica narrativa e descritiva, e o material não será apreciado/avaliado ou comparado.

\subsection{1 studio d A2}

Em studio $d A 2^{174}$, as orações relativas são explicitamente apresentadas aos

\footnotetext{
${ }^{171}$ FUNK et al., 2010.

${ }^{172}$ HILPERT et al., 2011.

${ }^{173}$ Nesta parte do texto, tratar-se-á das lições dos LDs em que as orações relativas são apresentadas. As estratégias que foram efetivamente empregadas pelos professores-voluntários em sala de aula e o modo como utilizaram e manipularam essas lições se encontram documentadas no anexo.
}

${ }^{174}$ Nível A2 do QECR. A apresentação das orações relativas no dativo se dá ao final do volume, entre o final do nível A2 e o início do B1. Portanto, entre o que o documento europeu denomina "nível elementar" (A2) e o utilizador independente, no nível denominado "limiar" (B1). No nível A2, o aluno "é capaz de compreender frases isoladas e expressões frequentes relacionadas com áreas de prioridade imediata (p. ex.: informações pessoais e familiares simples, compras, meio circundante). É capaz de comunicar em tarefas simples e em rotinas que exigem apenas uma troca de informação simples e direta sobre assuntos que lhe são familiares e habituais. Pode descrever de modo simples a sua formação, o meio circundante e, ainda, referir assuntos relacionados com necessidades imediatas". No B1, o aluno "É capaz de compreender as questões principais, quando é usada uma linguagem clara e estandardizada e os assuntos lhe são familiares (temas abordados no trabalho, na escola e nos momentos de lazer, etc.). É capaz de lidar com a maioria das situações encontradas na região onde se fala a língua-alvo. É capaz de produzir um discurso simples e coerente sobre assuntos que lhe são familiares ou de interesse pessoal. 
estudantes na unidade 6, intitulada "Ausgehen" ("Sair"), mais especificamente na terceira página da lição, sob o subtítulo "Rund ums Essen" ("Falando de comida"/"Comer e beber"). Entretanto, já na página dupla de apresentação da unidade, é proposta uma atividade de compreensão textual global. São apresentados ao aluno três textos sustentados pela linguagem verbal, além de diversas imagens, ora puramente visuais, ora de forma a consubstanciar os códigos verbal e visual. A tarefa consiste em identificar quais palavras contidas nos três textos verbais possam ser associadas a que imagens dentre as contidas na atividade. O exercício seguinte é baseado numa compreensão mais detalhada do texto, mediante o preenchimento de uma tabela. Tratase de indicar respostas às perguntas Wohin? (para onde?) e Was? (o quê?), em associação com as pessoas em torno das quais se articulam os três textos (elaborados em primeira pessoa). Em cada um deles está incluída uma oração relativa, mas a sua identificação não é proposta nem esperada neste momento inicial, uma vez que a presença dessa construção não interfere na realização das tarefas propostas.

Na página seguinte (contida no anexo), propõe-se a leitura de um texto com o título "Beruf Restaurantfachfrau" e a resposta de quatro questões sobre seu conteúdo (item 3.1). O pequeno texto de 14 linhas contém uma oração relativa no nominativo. Em seguida, o aluno deve ouvir declarações acerca do mesmo tema e identificar informações novas não contidas no texto escrito apresentado previamente. A atividade seguinte (3.2) já apresenta o tema gramatical mediante o uso de metalinguagem, bem como sua função: "Relativsätze: Personen oder Sachen genauer beschreiben" ("orações relativas: descrever mais exatamente pessoas ou coisas"). São propostos dois blocos de quatro frases (períodos incompletos) cada, identificados com os rótulos "Hauptsatz" (oração principal, termo conhecido pelos aprendentes, apresentado em studio d A2 há já várias lições) e "Relativsatz". Cabe ao aprendiz, com base no contexto e no conhecimento do gênero do correlato, associar as orações, formando períodos completos compostos de principal e relativa. Em seguida, surge um exercício de lacunas a serem preenchidas com os pronomes relativos adequados (3.3) e uma atividade que propicia ao

Pode descrever experiências e eventos, sonhos, esperanças e ambições, bem como expor brevemente razões e justificações para uma opinião ou um projeto". Cf. documento "Níveis do Marco Comum Europeu" da PUC-Rio, extraído de CONSELHO DA EUROPA (2001), e disponível em http://www.cce.puc-rio.br/ipel/N\%C3\%ADveis\%20do\%20Marco\%20Comum\%20Europeu.pdf, último acesso em: 08-12-2013. 
aprendiz a possibilidade de formular uma regra acerca da função e funcionamento das relativas alemãs (3.4): o aluno aprende que a oração relativa é uma subordinada, portanto com verbo ao final, que ela explica um nome da oração principal e que o pronome relativo se localiza após a vírgula. Estas informações foram reforçadas pelo professor-voluntário quando da apresentação da atividade (D) da lista de exercícios, de modo a determinar a função discursiva das orações relativas a serem criadas no texto.

Na página seguinte, são abordadas as orações relativas que se situam no meio de uma principal ("Der Koch, der im Restaurant 'Krone' arbeitet, macht die besten Schnitzel in der Stadt"'"O cozinheiro que trabalha no restaurante 'Krone' faz os melhores filés à milanesa (empanados) da cidade" - p. 93), com uma proposta de atividade para formar sentenças semelhantes (3.5). Logo, são apresentados os pronomes relativos no acusativo no contexto "explicar como se fazem os alimentos", a exemplo da sentença "Baklava ist ein türkischer Kuchen, den man aus Mehl, Wasser, Zucker und Nüssen macht”"175 ("Baklava é um bolo turco que se faz com farinha, água, açúcar e nozes"). É proposto ao aluno que explique a preparação de cinco alimentos, elaborando, para tal, orações relativas como a do modelo, o que implicará o uso dos pronomes relativos no acusativo (3.6). O professor-voluntário que aplicou esta lição a um dos grupos, alguns meses antes de adentrar a temática dos pronomes relativos no dativo, na unidade 11, declarou ter tratado as orações no nominativo e acusativo em aulas diferentes, acentuando o caráter sintético da abordagem desse tópico gramatical. Em cada uma das aulas, propôs atividades (A), (B), (C) e (D) ${ }^{176}$ ao alunado, com vistas a possibilitar o treino da estrutura.

As orações relativas voltam a ser tematizadas na unidade 11 de studio $d A 2$, intitulada "Mit Allen Sinnen" ("com todos os sentidos"), desta vez com os pronomes relativos no caso dativo. Diferentemente do que ocorre na lição 6, a estrutura gramatical a ser apresentada não aparece no texto verbal contido na página dupla que introduz a lição (p. 74 e 75, não incluídas no anexo). Ela surge primeiramente na página 80, no item 5 da unidade: "Anette Stramel, Deutschlehrerin" ("Anette Stramel, professora de alemão”). Oferece-se ao aluno um texto acerca de uma professora de

\footnotetext{
${ }^{175}$ P. 93. Todas as indicações de páginas de studio d A2 remetem a FUNK et al. (2010) nas referências.

${ }^{176}$ De acordo com a tipologia de exercícios de Neuner et al. (1981), abordada neste trabalho no item 2.2.1.2 desta dissertação. Verifique-se declarações do professor-voluntário no apêndice.
} 
alemão desprovida do sentido da visão. A primeira atividade (4.1) é uma introdução ao tema do texto e a segunda (4.2) consiste em cinco perguntas às quais devem ser associadas as linhas do texto em que se encontram as respostas a elas. O texto contém três orações relativas (preposicionadas) no dativo. A atividade seguinte (4.3) consiste na escuta seletiva de um texto e na anotação de respostas a questões propostas sobre seu conteúdo. Na página seguinte (item 4.4), as relativas são tematizadas com o subtítulo "Relativsätze: in, mit + Dativ" ("Orações relativas: [preposições alemãs que regem dativo] in, mit + dativo"). Compete ao aluno analisar orações relativas no dativo, na temática do texto da página anterior, e completar uma tabela com os pronomes relativos (nominativo, acusativo e dativo). A atividade propõe explicitamente a comparação com o item 3 da unidade 6, abordado há alguns parágrafos. No exercício seguinte (4.5), é proposto que os alunos construam períodos com orações relativas no dativo, com base no exemplo "Der ideale Deutschkurs ist ein Kurs, in dem..." (“O curso de alemão ideal é um curso no qual...”). Na página 86 (não contida no anexo), o exercício 7 propõe a construção (associação entre orações principais e relativas) no dativo não preposicionadas. O professor-voluntário acusa complementar sempre os exemplos do livro à página 81 com orações relativas não preposicionadas no dativo. Por esse motivo, esse tipo de oração foi incluída em nossa lista de exercícios.

\subsubsection{Schritte International 5}

Em Schritte International 5, as orações relativas são tematizadas na lição 2, intitulada "Unterhaltung" ("entretenimento"). O tema não aparece até a quinta página da lição (p. 24), no item C, “Das ist das Essen, das..." (“Esta é a comida que...”). O assunto não é introduzido dentro de textos, mas sim diretamente mediante a proposta de um exercício $(\mathrm{C} 1)^{177}$ no qual os alunos devem completar lacunas com os pronomes relativos no nominativo: die, der, das, die, em frases que abordam temas relacionados ao entretenimento (comida, filme, dar gorjeta). A associação pode ser feita com o

\footnotetext{
${ }^{177}$ A denominação dos exercícios mediante o emprego da letra C é a adotada na organização interna dessa unidade do livro e não remete à suprarreferida modalidade de exercícios "C" da tipologia de Neuner et al. (1981).
} 
gênero do correlato, mas a atividade oferece uma tabela com os pronomes no nominativo que também funciona como resposta, já que se vale dos mesmos exemplos.

O segundo exercício (C2), diretamente abaixo, introduz os pronomes relativos no acusativo, mas também inclui sentenças que devem ser completadas com o pronome no nominativo. A atividade inclui compreensão auditiva, consistindo a proposta em primeiramente completar as lacunas, logo ouvir as sentenças completas, com pronome, e comparar as respostas. O exercício, como o anterior, inclui uma tabela com os pronomes no acusativo, para ser usada para conferência por parte do aluno.

O terceiro exercício (C3) começa com um modelo de diálogo que inclui o uso do pronome relativo no nominativo e que está gravado, devendo ser ouvido pelos aprendizes, que o reproduzirão mediante a substituição da palavra neutra "Kinoprogramm" (programação do cinema) por outras no masculino, feminino e plural (trata-se, portanto, de um drill). O exercício oferece um segundo modelo de diálogo que deverá ser reproduzido com um emprego de outras palavras, gerando-se assim sentenças com o pronome relativo no acusativo. No exercício seguinte $(\mathrm{C} 4)$, já na página 25 , devem ser associadas frases a manchetes de notícias, a partir do tema/contexto. Depois, na atividade $\mathrm{C} 5$, o aluno deve ouvir frases completas incluindo um pronome relativo no dativo e completá-las. Também é oferecida uma tabela com o paradigma desses pronomes, nos três gêneros e no plural. No exercício C6, são oferecidos inícios de frases que devem ser completadas a partir do emprego de expressões também dadas, que levarão à criação de sentenças com pronome relativo no dativo. Exemplo: O início de frase (oração principal) "Hast du einen Freund..." ("Você tem um amigo...") pode ser completado utilizando-se a expressão "alles gelingen" ("sempre dar tudo certo"), indicada na tabela de possibilidades. O verbo "gelingen" abre espaço para um complemento no dativo (wem?/a quem?), podendo-se, assim, construir a oração relativa "Hast du einen Freund, dem immer alles gelingt?" ("Você tem um amigo para quem tudo sempre dá certo?”). Esta sentença e outras duas são indicadas no próprio exercício como exemplos. O exercício $\mathrm{C} 7$ propõe que os alunos escrevam períodos longos em duplas, utilizando orações relativas, de forma que se estabeleça uma competição com vistas a verificar que dupla construiu a sentença mais longa. 
As orações relativas são retomadas apenas na página 29, intitulada "Grammatik", e que oferece uma retomada/panorama dos temas gramaticais abordados na lição (os outros sendo a conjunção "obwohl" ("embora") e "Gradpartikeln" partículas de gradação/indicação de intensidade). No item "Relativpronomen und Relativsatz" ("pronome(s) relativo(s) e oração relativa"), é apresentada uma tabela com o paradigma de declinação dos pronomes relativos nos casos nominativo, acusativo e dativo, mediante a indicação de exemplos sob a forma de frases.

A principal diferença observada no tocante à abordagem das orações relativas em ambos os LD é o fato da explicitação desse tema gramatical, em studio d, partir em geral do trabalho com textos mais longos, com forte interação palavra-imagem, e, em Schritte, de atividades em que se lida principalmente com o nível da sentença, ainda que no contexto maior da lição ${ }^{178}$.

\title{
3.4 Credibilidade da pesquisa
}

\begin{abstract}
A ânsia de busca de novo conhecimento faz parte da natureza humana. Se por um lado a história da humanidade e, particularmente, a história da ciência, nos mostram as inquietações que levaram às grandes descobertas, com conseqüentes avanços, por outro lado nos mostram, também, como nem sempre o uso que é feito do novo conhecimento construído tem por finalidade o bem da humanidade. Será essa busca do novo sempre feita com liberdade, sem preconceitos, com humildade para entender e com grandeza para mudar? Mais complexa ainda é a questão do uso de novo conhecimento. Quem tem acesso ao novo conhecimento? Garante que direitos? De quem? Bastaria lembrarmos, como exemplo para reflexão, a questão do uso da energia nuclear no mundo. (CELANI, 2005, p. 103) [sic]

[...] nem o fazer ciência nem a linguagem são neutros e descomprometidos. (DE GRANDE, 2011, p. 25)
\end{abstract}

O presente trabalho foi conduzido tendo como norte rigorosos princípios de ética, tanto com relação aos sujeitos envolvidos nesta pesquisa (professores-voluntários, alunos-informantes) e à preservação de sua liberdade e dignidade, quanto no tocante aos

\footnotetext{
${ }^{178}$ Preferi referir-me a "textos mais longos [que um período ou sentença]" por estar ciente de que, no emaranhado de diferentes e por vezes díspares concepções de texto encontradas no seio da própria Linguística Textual, uma "frase completa" também pode ser encarada como texto (KOCH, 2011, p. XII). Em diversas semióticas, tem-se também a imagem entendida como texto. Entretanto, a intrincada discussão do(s) conceito(s) de texto não corresponde ao interesse e ao bojo da minha pesquisa.
} 
dados por eles fornecidos e aqui expostos e analisados. Baseia-se num comprometimento com a veracidade das informações coletadas, transcritas, manipuladas e aqui divulgadas com rigor e pormenor, e com o espírito crítico atuante quando da análise dos dados e execução da investigação dentro do paradigma misto de pesquisa adotado. Os dados divulgados o foram mediante autorização expressa e documentada dos informantes e professores-voluntários. Considerou-se, assim, na confecção dos termos de consentimento livres e esclarecidos, que

é indispensável o consentimento informado, esclarecido, na forma de diálogo contínuo e reafirmação de consentimento ao longo da pesquisa. Esse diálogo possibilitará ao pesquisador certificar-se de que os participantes entenderam os objetivos da pesquisa, seu papel como participantes, ao mesmo tempo que deixa clara a esses a liberdade que têm de desistir de sua participação a qualquer momento. (CELANI, 2005, p. 110)

Adotam-se, aqui, os critérios de credibilidade estipulados por Lincoln \& Guba (apud CANUTO, 2012, p. 92-93). Além do engajamento prolongado, o trabalho em andamento e em sua versão final foi submetido constantemente à avaliação de pares, doutores experientes em Linguística Aplicada e áreas afins, e os dados foram debatidos também com os professores-voluntários, conhecedores dos alunos-informantes e estruturas dos cursos (critério de credibilidade peer debriefing e member checking). Atendendo ao critério da triangulação, houve o emprego de diferentes referenciais teórico-metodológicos e fontes de dados e instrumentos com vistas à obtenção de informações claras e fiáveis. Assim, considerando-se o diálogo que se estabelece constantemente entre os diversos registros desta pesquisa (exercícios, depoimentos dos professores e outros dados coletados e anexados), retoma-se Erickson (2001, p.14, apud DE GRANDE, 2011, p. $15^{179}$ ), para quem

\begin{abstract}
a triangulação ocorre na medida em que a análise vai sendo realizada e as intuições acerca de padrões desenvolvidos com base em notas de campo são cruzadas e confirmadas em relação a dados de entrevista e documentos, o que leva a uma evidência mais forte do que seria possível se esta viesse apenas de uma fonte de informação.
\end{abstract}

Observem-se, na tabela abaixo, algumas situações durante as quais o trabalho foi submetido à apreciação de outros especialistas e publicamente divulgado:

179 A autora cita ERICKSON, F. Ethnographic description. In: AMMON, H. U; DITTMAR, N. E MATTHEIER. Sociolinguistics; an international handbook of the science of language and society. Berlin/New York: Walter de Gruyter, 1988. 


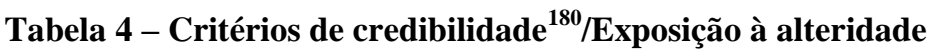

\begin{tabular}{|l|l|l|l|}
\hline Evento & Tipo de apresentação & Local & Data \\
\hline Exame de qualificação & Protocolo institucional & FFLCH/USP & 2013 \\
\hline Apresentação em evento & $\begin{array}{l}\text { Comunicação oral com } \\
\text { debate }\end{array}$ & $\begin{array}{l}\text { IX Jornada de Língua } \\
\text { Alemã, FFLCH/USP }\end{array}$ & 2013 \\
\hline Apresentação em evento & $\begin{array}{l}\text { Comunicação oral com } \\
\text { debate e presença de } \\
\text { debatedora doutora } \\
\text { especialista }\end{array}$ & $\begin{array}{l}\text { XIX Seminário de Teses } \\
\text { em Andamento, } \\
\text { IEL/Unicamp }\end{array}$ & 2013 \\
\hline $\begin{array}{l}\text { Apresentação oral do } \\
\text { disciplina de mestrado }\end{array}$ & $\begin{array}{l}\text { FFLCH/USP- } \\
\text { Disciplina FLM5381-2/1 } \\
\text { entrega de trabalho } \\
\text { escrito (capítulo de } \\
\text { metodologia em } \\
\text { versão preliminar), } \\
\text { debate }\end{array}$ & $\begin{array}{l}\text { Petodologia de } \\
\text { Pesquisa em } \\
\text { Didática e Ensino- } \\
\text { Aprendizagem de } \\
\text { Línguas Estrangeiras" }\end{array}$ & 2012 \\
\hline
\end{tabular}

Quanto à possibilidade de reduplicação externa e interna do trabalho, procurouse, quanto à primeira, que "pretende que qualquer pesquisador possa descobrir os mesmos fenômenos e gerar os mesmos construtos encontrados no estudo" (LIBERALI, 1994, p. 45), detalhar ao máximo possível a natureza das minhas intervenções, da ação e papel dos pesquisadores-voluntários na pesquisa, bem como o papel definido desempenhado pelos alunos-informantes, e os contextos gerais e específicos do estudo. Foram pormenorizadas as razões para escolhas dos grupos de informantes, bem como informações sobre o seu perfil, experiência de ensino-aprendizagem da língua etc. Descreveram-se detalhadamente os métodos de coleta e análise dos dados. Quanto à reduplicação interna, "ligada ao fato de outros pesquisadores com os mesmos construtos poderem combinar os dados da mesma forma que o pesquisador original" (idem, ibidem), procurou-se descrever os fatos de forma correta e precisa, evidenciando-se os caminhos epistemológicos e metodológicos adotados para que se chegasse às informações, conclusões e análises.

\footnotetext{
${ }^{180}$ O modelo desta tabela é extraído de Canuto (2012, p. 93).
} 
4. ANÁLISE DOS DADOS 
A linguagem é o instrumento graças ao qual o homem modela o seu pensamento, seus sentimentos, suas emoções, seus esforços, sua vontade e seus atos, o instrumento graças ao qual ele influencia e é influenciado, a base última e mais profunda da sociedade humana. Mas é também o recurso último e indispensável do homem, seu refúgio nas horas solitárias em que o espírito luta contra a existência, e quando o conflito se resolve no monólogo do poeta e na meditação do pensador.

(HJELMSLEV, 1975, p. 1-2)

Uma análise da produção textual de alunos pode, a priori, considerar o texto como produto ou como processo. De acordo com Soares (2013, p. 21),

a abordagem do texto como processo está em linha com a vertente dialógica de ensino. Nela, o foco da escrita recai sobre as habilidades linguísticas do aluno tais como o planejamento, a seleção de ideias, a revisão e a editoração, tendo sempre em mente o contexto de produção (quem fala, para quem fala, onde fala e com qual propósito). [...]

Soares (2013, p. 20) também nos ensina que

\begin{abstract}
a abordagem do texto como produto, em linha com a vertente tradicional de ensino, enfoca a escrita a partir do conhecimento linguístico do aluno, privilegiando o uso apropriado do vocabulário, da sintaxe e dos elementos coesivos (BADGER \& WHITE, 2000, p. 153). Em geral, o texto é resultado de uma única tentativa do aprendiz de colocar em palavras o que pretende dizer. $^{181}$
\end{abstract}

Tendo em conta essas considerações, é importante ressaltar que este trabalho não foi realizado tendo em mente uma concepção tradicional de ensino ${ }^{182}$. Esse tipo de visão dos gestos de ensinar e aprender não perfaz minha escolha-construção do objeto de estudos, da fundamentação teórica ou da metodologia de trabalho adotada. Também não corresponde às prescrições das duas escolas em que se conduziram os testes, às propostas dos livros didáticos usados e às ações e crenças dos professores-voluntários.

\footnotetext{
${ }^{181}$ A autora faz referência, nesse trecho, a BADGER, R.; WHITE, G. A process genre approach to teaching writing. ELT Journal, v. 54/2, abril, 2000.

${ }^{182}$ A perspectiva tradicional de ensino, conforme Leão (1999, p. 190), em sua dimensão epistemológica, "parte do pressuposto de que a inteligência é uma faculdade que torna o homem capaz de armazenar informações, das mais simples às mais complexas. Nessa perspectiva é preciso decompor a realidade a ser estudada com o objetivo de simplificar o patrimônio de conhecimento a ser transmitido ao aluno que, por sua vez, deve armazenar tão somente os resultados do processo. Desse modo, na escola tradicional o conhecimento humano possui um caráter cumulativo, que deve ser adquirido pelo indivíduo pela transmissão dos conhecimentos a ser realizada na instituição escolar (Mizukami, 1986). O papel do indivíduo no processo de aprendizagem é basicamente de passividade." A autora faz referência a MIZUKAMI, M. G. N. Ensino: as abordagens do processo. São Paulo: EPU, 1986.
} 
Apesar disso, a correção de exercícios gramaticais, principalmente os mais reprodutivos, implica a aplicação de critérios de erro e acerto, uma vez que se busca, entre outras coisas, que o aluno reproduza aspectos de um conhecimento gramatical cristalizado que lhe foi apresentado. Durante a correção de textos, tendo como foco a análise das orações relativas construídas pelos informantes dentro desses textos, será averiguado seu grau de correção gramatical tendo em vista o insumo oferecido como modelo pelos professores, mas também se considerará o texto como uso da linguagem de modo funcional, com vistas à comunicação, ou seja, o propósito daquilo que, no texto, o aluno fala, relevando-se com suma importância o critério compreensibilidade. Desse modo, o texto será considerado produto e processo. 


\subsection{Os dados obtidos e seus desdobramentos}

$\mathrm{Na}$ presente subdivisão do trabalho, pretende-se proceder à análise dos dados coletados junto aos dois grupos de informantes que nos forneceram os registros documentados no apêndice. Com isso, o objetivo da análise consiste em encontrar respostas às perguntas de pesquisa perquiridas nesta dissertação. Procurar-se-á chegar a conclusões acerca dos processos de ensino-aprendizagem das orações relativas do alemão levados a cabo pelos sujeitos de pesquisa (professores e alunos) tendo como base para ponderações nosso referencial teórico resenhado na parte 1 deste texto. Novas hipóteses serão levantadas e testadas a partir daquilo que nos apresentam os dados.

Assim, serão aqui brevemente retomadas nossas perguntas de pesquisa. Elas se referem, basicamente, à identificação de possíveis diferenças a serem constatadas entre os produtos elaborados pelos alunos dos dois grupos, seguindo, respectivamente, as progressões analítica e sintética de tópicos gramaticais em cursos de ALE (veja-se item 1.3 dos fundamentos teóricos). Essa pergunta será perscrutada ao final da análise, quando já tiverem sido apresentados e analisados os exercícios dos dois grupos. Antes, serão verificadas as possíveis dessemelhanças entre a produção dos alunos em exercícios mais controlados e mais livres, de acordo com a tipologia de Neuner et al. (1981), resenhada na parte 2 deste trabalho. Por fim, objetiva-se concluir se houve indícios de uma sobrecarga da memória de trabalho dos informantes que aprenderam as orações relativas do alemão de acordo com a abordagem analítica, o que consistiria num exemplo claro de input sobejo, de acordo com a hipótese krashiana do i+1, discutida na tabela 3, parte 1 deste texto. Essas perguntas serão abordadas considerando-se o fato de que os erros oferecem informações ao pesquisador acerca do andamento do processo de aprendizado dos alunos (CORDER, 1967).

A parte prática desta pesquisa, ou seja, o nosso experimento empírico, consistiu, assim, na aplicação de exercícios entre os aprendizes-informantes por parte de professores-voluntários colaboradores. Esses exercícios, elaborados de acordo com a escala de progressão de Neuner et al. $(1981)^{183}$, partiram de atividades mais controladas

\footnotetext{
${ }^{183}$ Verificar descrição dessa escala na parte 2 do presente trabalho.
} 
e reprodutivas até a livre elaboração de um texto em que a estrutura gramatical tematizada, as orações relativas do alemão, fosse empregada ao menos cinco vezes (o que nem sempre se deu, com algumas produções aquém dessa marca). $\mathrm{O}$ controle dos resultados desta atividade nos leva a observar aspectos importantes relativos ao processo de aprendizagem do tópico supramencionado por parte dos alunos, não sendo possível, devido às limitações de tempo de que se dispõe ${ }^{184}$ para completar este trabalho, averiguar os estágios do processo de aquisição, automatização e assimilação total da estrutura, uma vez que dito processo, cuja duração varia de aprendiz para aprendiz e não pode ser mensurada de forma clara e estanque, em sua grande complexidade, implicaria diversas coletas de dados em diferentes etapas do processo de ensino-aprendizagem. Além disso, convém lembrar que, com nosso experimento, realizamos um recorte fenomenológico de sala de aula que representa uma realidade presente nos cursos em que se adotam os livros didáticos com os quais trabalhamos: o momento em que o aluno reconhece uma estrutura gramatical nova num dado texto, esquematiza conhecimentos a respeito do funcionamento dessa estrutura (SOS-Prinzip, cf. NEUNER; KRÜGER; GREWER, 1991 ${ }^{185}$ ) e põe em prática os novos saberes adquiridos através da feitura de exercícios de fixação e de (re)produção linguística. Gomes assim resume esse tipo tão comum de prática, adotado pelos professoresvoluntários desta pesquisa e sugerido, em linhas gerais, pelos LDs analisados ${ }^{186}$ (veja-se apêndice):

\begin{abstract}
Muitas aulas de língua estrangeira (LE) têm sido realizadas conforme o desenvolvimento a seguir: abordagem de um texto escrito visando à compreensão global de seu conteúdo. Em seguida, o objetivo da sua leitura se transforma no estudo de um elemento gramatical e o professor passa a expor e a descrever as regras gramaticais contidas no texto. Na sequência, passa-se à resolução de atividades que se constituem, na maioria das vezes, em exercícios estruturais pré-elaborados os quais integram o material utilizado pelo professor. Por fim, após a prática repetitiva por intermédio de exercícios do item que constitui o objetivo da aula, passa-se à avaliação bimestral, a qual tem por finalidade examinar se o aluno assimilou ou não o conteúdo estudado. (GOMES, 2011, p. 16)
\end{abstract}

\footnotetext{
${ }^{184}$ Prazo-padrão para a realização de uma dissertação de mestrado no Programa de Pós-Graduação em Língua e Literatura Alemão da FFLCH/USP.

185 Sammeln - Ordnen - Systematisieren, i.e., coletar informação em um texto - ordená-la - sistematizála.

${ }^{186}$ Como afirmado em outras passagens desta dissertação, não se pretende, aqui, proceder a uma análise crítica das práticas pedagógicas observadas e nem propor alternativas ao seu funcionamento.
} 
Neste trecho do trabalho, serão listadas, portanto, as orações relativas construídas pelos informantes. Com base no modelo que nos oferece Figueiredo, F. (2004), e de modo a facilitar a fruição deste texto também por parte de leitores não fluentes em alemão, as sentenças serão listadas da seguinte maneira:

(*) Oração relativa em alemão formulada pelo aprendiz-informante contendo erros de quaisquer tipo.

- Oração do aluno com erros de todos os tipos corrigidos pelo pesquisador. [Tradução dessa oração ao português.]

Embora, no presente trabalho, a atenção seja dedicada, prioritariamente, à análise das orações relativas produzidas pelos alunos e à verificação dos elementos que lhes caracterizam morfossintaticamente (posição do verbo, posição e flexão do pronome relativo, correspondência relativo/correlato, pontuação específica - erros primários, para os propósitos desta pesquisa), erros de outra natureza (secundários) serão corrigidos por questões didáticas, embora, por não constituírem o ponto focal das análises, não se lhes confira maior importância caso não afetem a construção que é objeto deste trabalho. Será empregado o ponto de interrogação no caso de aglomerações de palavras sem possibilidade de depreensão segura de sentido. As sentenças contendo erros no tocante às vicissitudes das Relativsätze serão sinalizadas com (*), enquanto aquelas que contiverem erros de outra sorte e que não influam na construção pesquisada não receberão esse sinal. Apesar disso, a inclusão da versão corrigida da frase e sua tradução alertará o leitor quanto à presença de erros de outros tipos na redação dos informantes, uma vez que, no caso de construções sem erros, estará ausente a reescritura da frase introduzida pelo símbolo “•”. A análise dos erros identificados será subsumida, num segundo momento, pelas categorias classificatórias de Figueiredo, F. (2004), de modo que se possa, ao final da análise, quantificar e qualificar os erros encontrados nos exercícios e buscar, a partir deles, a compreensão e interpretação mais globais de sua produção. A análise dos erros se pretenderá objetiva e rigorosa, calcada nos nossos fundamentos teóricos e tendo como base de "acertos" as orações relativas do alemãopadrão, assim como descritas na parte 1.1.2.1 deste trabalho e apresentadas aos alunosinformantes pelos seus professores em curso. A catalogação dos erros, entretanto, nem sempre dará lugar a uma estipulação segura do tipo de desvio cometido. Pelo fato de não se retornar aos alunos após a coleta de dados para interpelá-los acerca dos porquês 
de suas formulações, em alguns casos apenas será possível levantar hipóteses, permanecendo, por isso, algumas questões parcialmente em aberto.

No âmbito dos erros primários, faz-se imprescindível lembrar que, no caso das declinações do alemão, existem formas que se repetem, porém com diferentes funções, como é o caso do pronome relativo "der", podendo ocupar tanto a posição de nominativo masculino singular quanto de dativo feminino singular. Nos casos de sua ocorrência mal posicionada, far-se-á importante analisar qual das formas foi eleita pelo aluno, nem sempre sendo possível sua identificação de forma absoluta e indubitável. A respeito, nos lembra Quites (1997, p. 21):

No que diz respeito a declinações do alemão padrão, estas existem em três tipos: quanto ao caso, ao género e ao número, conforme explica $\mathrm{C}$. MÜLLER (1988), embora muitas destas formas sejam iguais para vários tipos de declinação. [...] A. RIEUSSEC (1989, p. 29) explica que os erros em alemão por declinação são conseqüência do fato de o aluno não estar ainda seguro quanto às regras do caso, do gênero e/ou do número. ${ }^{187}[$ sic $]$

\subsection{1 $1^{\circ}$ grupo de informantes (A): Schritte International (6 informantes)}

\subsubsection{Atividade A}

No primeiro grupo de informantes, aquele constituído pelos seis alunos frequentadores do curso da instituição na qual se adota Schritte International como livro didático, e junto ao qual o desenvolvimento das atividades se deu de acordo com a abordagem analítica (de acordo com Wilkins [1978], tipo de progressão de tópicos gramaticais em LDs e cursos de LE em que o tema gramatical vai sendo apresentado de forma fragmentária ao aprendiz ${ }^{188}$ ), observou-se que a realização do primeiro exercício,

\footnotetext{
${ }^{187}$ A autora cita RIEUSSEC, A. Der Fehler im Fremdsprachenunterricht - ein Verstoß gegen die Norm der Zielsprache? Der Fremdsprachliche Unterricht. v. 96, p.27-31, 1989, e MÜLLER, Christian. Flexionsmorpheme und Kongruenz des Adjektivs. In: Duas línguas em contraste - Português e Alemão (1988: Porto). Actas do 1. Colóquio Internacional de Lingüistica Contrastiva Português-Alemão. Porto: Faculdade de Letras do Porto, Instituto de Estudos Germanísticos, 1988. p. 111-122.

${ }^{188}$ Verifique-se capítulo dedicado a esta temática na parte segunda do presente trabalho.
} 
de tipo $\mathrm{A}^{189}$, ocorreu sem que se produzissem erros, ou seja, as orações formadas por todos os estudantes do grupo são, em sua totalidade, sintática e semanticamente corretas e aceitáveis na língua alemã. A atividade consistia em associar as orações principais dadas na primeira coluna às relativas indicadas na segunda, de modo a conformar períodos que reproduzissem semântica e gramaticalmente informações contidas num texto previamente apresentado aos aprendizes (vide anexo). Assim, as frases formadas pelos alunos integrantes do primeiro grupo, aquele em que se adota Schritte International, foram:

a. Margarinien ist ein Land, | 3. in dem Pistole wohnte. [Margarínia é um país no qual Pistole morava.]

b. Vor 70 Jahren lebte Antek, | 1. der Besen machte. [Há 70 anos viveu Antek, que fazia vassouras.]

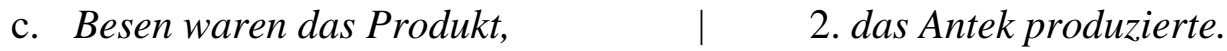
[Vassouras eram o produto que Antek produzia.]

d. Man sagt, dass Antek ein Mann ist, | 5. der ehrlich war. [Diz-se que Antek é um homem que era honesto.]

e. Die Türkei ist ein Land, | 4. das größer ist. [A Turquia é um país que é maior.]

Abaixo listamos formulações também consideradas corretas, de acordo com os princípios de erros e acertos abordados na fundamentação teórica do trabalho (itens 1.1.2.1 e 1.1.3), considerando-se as vicissitudes das orações relativas e também a compreensibilidade (um informante), uma vez que, ao tratar-se de qualificações do personagem Antek, as duas relativas poderiam ser aplicadas tanto a uma oração principal quanto à outra, resultando em orações sintática e semanticamente viáveis:

b. Vor 70 Jahren lebte Antek, | 5. der ehrlich war. [Há 70 anos viveu Antek, que era honesto.]

d. Man sagt, dass Antek ein Mann ist, | I. der Besen machte. ${ }^{189}$ Retome-se descrição da tipologia de exercícios de Neuner et al. (1981) na parte 2 deste trabalho,
subcapítulo 2.2.1.2. 
[Diz-se que Antek é um homem que fazia vassouras.]

Para montar as frases, o aprendiz dispunha de conhecimentos prévios contextualizados acerca do personagem, obtidos a partir da leitura do texto, bem como de indícios gramaticais que também deveriam levá-lo ao encontro da oração complementar para cada período, a partir da relação entre o gênero do correlato e o do pronome relativo (Antek/der, Produkt/das, ein Land/[in] dem etc.).

\subsubsection{Atividade B}

$\mathrm{Na}$ segunda atividade, menos reprodutiva que a anterior ${ }^{190}$, orações principais eram dadas e, com relação às orações relativas a serem completadas, foram indicados elementos que induzissem seu desenvolvimento, como pronomes relativos e/ou verbos (exceção para a frase 3). Os dados coletados foram os seguintes (as construções criadas pelos informantes serão sublinhadas):

Informante $1^{191}$ :

(*) 1. Das ist der Mann, den ich ein Kind habe.

- Das ist der Mann, mit dem ich ein Kind habe.

[Este é o homem com quem tenho uma criança/um filho.]

(*) 2. Ich rede immer mit meiner Ärztin, der sie wie ein Schauspilare lauft.

- $\quad$ Ich rede immer mit meiner Ärztin, die wie eine Schauspielerin läuft.

[Eu converso sempre com minha médica, que corre/anda como uma atriz.]

3. Wir haben drei Kinder, die Mechnikel werden wollten.

- Wir haben drei Kinder, die Mechaniker werden wollten.

[Nós temos três filhos que queriam se tornar mecânicos.]

\footnotetext{
${ }^{190}$ De acordo com a tipologia de Neuner et. al. (1981) esboçada na parte 2 deste trabalho (item 2.2.1.2), correspondente ao tipo B em uma escala de progressão em que o exercício de tipo A é o mais controlado ou reprodutivo, e o de tipo $\mathrm{D}$, o mais livre ou produtivo.

${ }^{191}$ De um total de seis informantes neste grupo.
} 
4. não foi feita.

5. Margarinien ist ein kleines Land, in dem Pistole wohnte.

[Margarínia é um pequeno pais no qual Pistole morava.]

\section{Informante 2:}

1. Das ist der Mann, den alle geloben.

- Das ist der Mann, den alle gellobt haben/lobten.

[Este é o homem que todos elogiaram/elogiavam.]

2. Ich rede immer mit meiner Ärztin, der ich alles erzählen kann.

[Eu converso sempre com minha medica, a quem posso contar tudo.]

3. Wir haben drei Kinder, die viele Energie haben.

- Wir haben drei Kinder, die viel Energie haben.

[Nós temos três crianças/filhos que têm muita energia.]

(*) 4. In der Sprachenschule, in dem wir lernen, die gute Lehrer hat.

- In der Sprachenschule, in/an der wir lernen, gibt es gute Lehrer.

[Na escola de idiomas na qual estudamos há bons professores.]

5. Margarinien ist ein Land, in dem Pistole wohnte.

[Margarinien é um país no qual Pistole morava.]

\section{Informante 3:}

(*) 1. Das ist der Mann, den ein großes auto hat.

- Das ist der Mann, der ein großes Auto hat.

[Este é o homem que tem um carro grande.]

(*) 2. Ich rede immer mit meiner Ärztin, der ist die besten in mein land.

- $\quad$ Ich rede immer mit meiner Ärztin, die die beste in meinem Land ist.

[Eu converso sempre com minha médica, que é a melhor no meu país.]

3. Wir haben drei Kinder, die sehr intelligenten sind.

- Wir haben drei Kinder, die sehr intelligent sind.

[Nós temos três filhos que são muito inteligentes.] 
(*) 4. In der Sprachenschule, der ****ist wir lernen, 192

- In der Sprachenschule, in/an der wir lernen,

[Na escola de idiomas, na qual nós estudamos,

(*) 5. Margarinien ist ein kleines Land, das Antek Pistole wohnte.

- Margarinien ist ein kleines Land, in dem Antek Pistole wohnte.

[Margarínia é um pequeno país no qual Antek Pistole morava.]

\section{Informante 4:}

1. Das ist der Mann, den ich mich nicht erinnern kann.

- Das ist der Mann, an den ich mich nicht erinnern kann.

[Este é o homem do qual eu não consigo me lembrar.]

(*) 2. Ich rede immer mit meiner Ärztin, der immer um mich gekummert hat.

- Ich rede immer mit meiner $\ddot{A} r z t i n$, die sich immer um mich gekümmert hat.

[Eu converso sempre com minha médica, que sempre cuidou de mim.]

(*) 3. Wir haben drei Kinder, denen an der Porto Seguro Schule besuchen.

- Wir haben drei Kinder, die die Porto-Seguro-Schule besuchen.

[Nós temos três filhos que frequentam a escola Porto Seguro.]

(*) 4. In der Sprachenschule, $\underline{\text { der }} \underline{\text { bei }}$ wir lernen, hei $\beta$ t****.

- Die Sprachenschule, an/in der wir lernen, heißt****.

[A escola de idiomas na qual estudamos se chama $* * * *$.]

5. Margarinien ist ein kleines Land, in dem Pistole wohnte.

[Margarínia é um pequeno país no qual Pistole morava.]

\section{Informante 5:}

1. Das ist der Mann, den ich getroffen habe.

[Este é o homem que eu encontrei.]

(*) 2. Ich rede immer mit meiner Ärztin, der mein Nachbar auch ist.

- Ich rede immer mit meiner Ärztin, die auch meine Nachbarin ist.

[Eu converso sempre com minha médica, que também é minha vizinha.]

3. Wir haben drei Kinder, die sehr schöne sind.

\footnotetext{
${ }^{192}$ Os asteriscos correspondem ao nome da instituição de ensino, mantido em sigilo.
} 
- Wir haben drei Kinder, die sehr schön sind.

[Temos três crianças/filhos que são muito bonitas/os.]

4. In der Sprachenschule, in der wir lernen, etwas komische passiert ist.

- In der Sprachenschule, in der wir lernen, ist etwas Komisches passiert.

[ $\mathrm{Na}$ escola de idiomas na qual estudamos aconteceu algo estranho.]

5. Margarinien ist ein kleines Land, in dem Antek Pistole wohnte.

[Margarinien é um pequeno país no qual Antek Pistole morava.]

\section{Informante 6:}

1. Das ist der Mann, den ich aus Margarinien kennengelernt habe.

- Das ist der Mann, den ich in Margarinnien kennen gelernt habe.

[Este é o homem que eu conheci em Margarínia.]

(*) 2. Ich rede immer mit meiner Ärztin, der eine sehr interessante Frau ist.

- Ich rede immer mit meiner Ärztin, die eine sehr interessante Frau ist. [Eu converso sempre com minha médica, que é uma mulher muito interessante.]

3. Wir haben drei Kinder, die sehr schönen sind.

- Wir haben drei Kinder, die sehr schön sind.

[Temos três crianças que são muito bonitas.]

4. In der Sprachenschule, bei der wir lernen, sind wir.

- Wir sind in der Sprachenschule, in/an der wir lernen.

[Estamos na escola de idiomas na qual estudamos].

5. Margarinien ist ein kleines Land, in dem Pistole wohnte.

[Margarínia é um pequeno país no qual Pistole morava.]

Observando-se os dados acima transcritos, registra-se um total de 16 orações morfossintaticamente bem formuladas, se se consideram os requisitos mínimos para a construção de orações relativas alemãs gramaticalmente corretas (posição, gênero, número e caso do pronome relativo, posição do(s) verbo(s) na frase) de um total de trinta, resultando em $53,4 \%$ de orações certas. Nesta asserção, consideram-se como corretas, de acordo com a concepção de erro que se adota neste trabalho e sobre a qual se discorre no capítulo 1 da dissertação, construções que correspondam ao modelo de 
orações relativas apresentados aos aprendizes pelos LDs analisados e empregados e endossados pelos professores-voluntários ${ }^{193}$, uma vez que estes últimos, nos depoimentos contidos no anexo, declaram não haver ensinado aos alunos outros paradigmas gramaticais de formulação de orações relativas no alemão ${ }^{194}$.

Faz-se notório o emprego de uma estratégia específica por parte de cinco dos seis informantes no tocante à frase de número 5, que consistiu na cópia de uma oração contida no exercício anterior ("Margarinien ist ein kleines Land, in dem Pistole wohnte"). Considera-se que a estratégia de retirada da resposta da atividade anterior, apesar de seu caráter reprodutivo ${ }^{195}$, é válida; entretanto, se desconsideramos o item 5, no qual a cópia da resposta era possível, obtemos um total de 25 frases, das quais 8 estão corretas.

São diversas as implicações relacionadas aos erros e acertos dos aprendizes nessa questão. Primeiramente, temos de considerar outros conhecimentos de língua alemã, além daqueles referentes à formulação das orações relativas, que constituem prérequisitos para a elaboração de períodos sintática (e semanticamente) adequados de acordo com as regras de funcionamento do alemão-padrão. Além do domínio das orações relativas e elementos que as compõem, faz-se mister que o aluno conheça o gênero dos substantivos implicados e suas flexões, bem como a valência dos verbos

\footnotetext{
${ }^{193}$ Correspondendo à norma culta do alemão-padrão.

${ }^{194}$ Evidentemente, caso algum aluno formulasse uma sentença existente em certas variantes da língua alemã como "Der Mann, wo ich sehe", esse emprego de "wo" como pronome relativo não poderia ser sinalizado como incorreto. Competiria ao professor, nesse caso, explicar ao aluno autor dessa construção que implicações sociolinguísticas e comunicativas (pragmático-funcionais) estariam envolvidas no emprego dessa construção. Vale lembrar, porém, que não ocorreram registros dessa natureza e que, ainda segundo os professores-voluntários, os informantes não possuíam conhecimentos prévios da língua alemã, construídos a partir de outras fontes de insumos que não os cursos e aulas em questão, e não poderiam, assim, dominar conscientemente outras variedades de orações relativas correspondentes a diferentes registros linguísticos ou variantes diacrônicas ou diatópicas do alemão.
}

${ }^{195}$ Considera-se que a estratégia de cópia, embora mais reprodutiva que propriamente produtiva, também acarreta implicações cognitivas relacionadas à compreensão dos insumos linguísticos ofertados ao aluno, uma vez que copiar uma sentença contida num texto significa, primeiramente, ser capaz de localizar a forma adequada e reproduzi-la em outro contexto em que também seja cabível. Na produção linguageira, de forma geral, produção e reprodução se confundem e sobrepõem constantemente, uma vez que parte significativa de nossa produção discursiva consiste na reprodução de formulações integrantes do sistema linguístico que não criamos, mas sim repetimos e empregamos, ainda que sejamos todos co-autores das línguas naturais que falamos e que estão em constante transformação. Quanto à noção de estratégia, baseio-me na definição de Cohen (1990, p. 5, apud ROSA; BASSO, 2010, p. 91), "processos de aprendizagem que são conscientemente selecionados pelo aprendiz". Fonte citada pela autora: COHEN, A. D. Language learning; insights for learners, teachers, and researchers. Boston: Heinle \& Heinle, 1990. 
empregados. É relevante, ainda, o conhecimento de expressões idiomáticas e do uso geral da língua, no sentido de saber como se dizem as coisas. O não-domínio dessas questões resulta em frases como "Das ist der Mann, den ich ein Kind habe" (Inf. 1), em vez de "Das ist der Mann, mit dem ich ein Kind habe" ("Este é o homem, do qual/com o qual eu tenho uma criança"). Já uma construção como "Das ist der Mann, den alle geloben" (Inf. 2), incorreta devido à questão da flexão verbal, faltando ainda, ao final da frase, o auxiliar haben para o emprego bem-sucedido do Perfekt (o particípio passado ou Partizip II seria, então, gelobt), apresenta o registro adequado do pronome relativo e a posição correta do verbo, não sendo contabilizada, assim, entre os erros primários. No caso da construção "Das ist der Mann, den ich mich erinnern kann" (Inf. 4), observa-se um erro de valência verbal, sendo que o verbo sich erinnern abre espaço para um complemento preposicionado introduzido por an, que rege o acusativo, caso no qual o pronome indicado pelo estudante se apresenta. Em "In der Sprachenschule, $\underline{\text { der }} \underline{\text { bei }}$ wir lernen, heißt ****" (Inf. 4), observa-se o pronome feminino devidamente declinado no dativo, em indicação de lugar, mas a preposição inadequada (provavelmente por interferência da combinação arbeiten bei), notando-se ainda a inversão da posição canônica preposição + pronome. Questões relativas à declinação de artigos e adjetivos não foram contabilizadas entre os erros que interferem na construção da oração relativa em si (ex.: "Ich rede immer mit meiner Ärztin, der ist die besten in mein[Ø] land") (Inf. $3)$.

Dentre os erros que estão diretamente associados à estrutura oração relativa, encontram-se:

1) erros relativos ao paradigma de declinação - gênero, número e/ou caso - do pronome:

(*) a. In der Sprachenschule, in $\underline{\text { dem }}$ wir lernen, die gute Lehrer hat. (Inf. 2)

(*) b. Das ist der Mann, den ein großes auto hat. (Inf. 3)

(*) c. Ich rede immer mit meiner Ärztin, der sie wie ein Schauspilare lauft (1)

(*) d. Ich rede immer mit meiner Ärztin, der ist die besten in mein land. (Inf. 3)

(*) e. Ich rede immer mit meiner Ärztin, der immer um mich gekummert hat. (4)

(*) f. Ich rede immer mit meiner Ärztin, der mein Nachbar auch ist. (Inf. 5)

(*) g. Ich rede immer mit meiner Ärztin, der eine sehr interessante Frau ist. (6) 
(*) h. Wir haben drei Kinder, denen an der Porto Seguro Schule besuchen. (4)

(*) i. In der Sprachenschule, $\underline{\text { der }}$ ****ist wir lernen, ${ }^{196}$ (Inf. 4)

(*) j. Margarinien ist ein kleines Land, das Antek Pistole wohnte. (Inf. 3)

Analisando-se os exemplos acima transcritos, observam-se seis ocorrências de troca de gênero do pronome (a, c, d, e, f, g) e três de caso $(b, i, j)$. Não se registra ocorrência de troca de número. No caso das orações c, d, e, f, g, a questão identificada é relativa ao gênero, já que o pronome der foi empregado como nominativo em todas as sentenças, no lugar de die. Na oração „Ich rede immer mit meiner Ärztin, der sie wie ein Schauspilare lauft" (Inf. 1), o pronome relativo, indicado no exercício, foi ignorado, e um pronome pessoal foi introduzido para assumir a função de sujeito da oração.

2) erros relativos à posição verbal:

(*) a. Ich rede immer mit meiner Ärztin, der ist die besten in mein land. (Inf. 3)

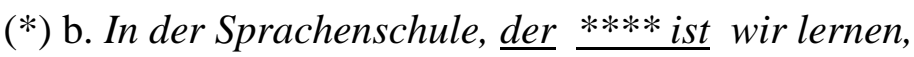
(Inf. 3)

$\mathrm{Na}$ análise deste quesito, registraram-se apenas dois erros de posição verbal nas orações relativas, cometidos pelo mesmo informante. Pode-se afirmar, assim, que uma das características básicas das orações relativas, enquanto subordinadas, foi satisfatoriamente assimilada pelo grupo de forma geral, a saber, a situação do verbo ao final da frase.

\subsubsection{Atividade C}

Nesta atividade, deveriam formar-se duas orações relativas, com vistas a completar o período iniciado, sem que fossem indicadas quaisquer pistas que guiassem à sua conformação (pronomes, verbos etc.). Os resultados obtidos foram:

\footnotetext{
${ }^{196}$ Os asteriscos correspondem ao nome da instituição de ensino.
} 


\section{Informante 1:}

(*) a. Die Geschichte von Antek Pistole ist der Roman, Antek Pistole, ist der Roman von die Geschichte.

[A história de Antek Pistole é o romance, Antek Pistole, é o romance do história.]

- não se construiu oração relativa

(*) b. Zwischen Europa und Asien liegt die Türkei, Türkei liegt zwichen Europa und Asien.

[Entre Europa e Ásia localiza-se a Turquia, a Turquia se localiza entre Europa e Ásia.]

- $\quad$ não se construiu oração relativa

\section{Informante 2:}

a. Die Geschichte von Antek Pistole ist der Roman, den alle gute finden. Die Geschichte von Antek Pistole ist der Roman, den alle gut finden. [A história de Antek Pistole é o romance que todos acham bom.]

b. Zwischen Europa und Asien liegt die Türkei, die alle geloben.

- Zwischen Europa und Asien liegt die Türkei, die alle loben/gelobt haben. [Entre Europa e África fica a Turquia que todos elogiam/elogiaram.]

\section{Informante 3:}

(*) a. Die Geschichte von Antek Pistole ist der Roman, den internet benutzt. [A história de Antek Pistole é o romance que utiliza a internet/que a internet utiliza.]

- ?

b. Zwischen Europa und Asien liegt die Türkei, die schonesten platz in Europa ist.

- Zwischen Europa und Asien liegt die Türkei, die der schönste Ort in Europa ist.

[Entre Europa e Ásia fica a Turquia, que é o lugar mais bonito na Europa.] 


\section{Informante 4:}

(*) a. Die Geschichte von Antek Pistole ist der Roman, dem in Margarinien wohnte.

[A história de Antek Pistole é o romance que/ao qual em Margarínia morava.]

- ?

b. Zwischen Europa und Asien liegt die Türkei, die nicht so groß ist. [Entre Europa e Ásia fica a Turquia, que não é tão grande].

\section{Informante 5:}

a. Die Geschichte von Antek Pistole ist der Roman, den ich nie gelesen habe. [A história de Antek Pistole é o romance que eu nunca li.]

b. Zwischen Europa und Asien liegt die Türkei, die ich schon einmal besucht habe.

[Entre Europa e Ásia fica a Turquia, que eu já visitei.]

\section{Informante 6:}

(*) a. Die Geschichte von Antek Pistole ist der Roman, die aus Margarinien ist.

- Die Geschichte von Antek Pistole ist der Roman, der aus Margarinien ist. [A história de Antek Pistole é o romance que é de Margarínia.]

b. Zwischen Europa und Asien liegt die Türkei, die ein schone Land ist. - $\quad$ Zwischen Europa und Asien liegt die Türkei, die ein schönes Land ist. [Entre Europa e Ásia fica a Turquia, que é um país bonito.]

Analisando-se estes dados, obtemos, de um total de doze orações, seis bemformadas, ou seja, 50\%. Dos seis informantes, apenas um (Inf. 5) construiu duas orações corretas, e não mais que um (Inf. 1) cometeu erros significativos/primários, ou seja, relacionados às características primordiais das orações relativas anteriormente mencionadas neste capítulo. Assim como quando da análise das respostas da atividade B, não foram contabilizados erros de declinação de adjetivos e ortografia. Nota-se que a mesma informante (2) repetiu o uso indevido do verbo loben no Perfekt, como na 
atividade B ("Zwischen Europa und Asien liegt die Türkei, die alle geloben"), tendo, todavia, situado o verbo ao final da frase.

Considerando-se as características primordiais a serem observadas quando da construção das orações relativas, observamos os seguintes erros específicos:

1) erros relativos ao paradigma de declinação - gênero, número e/ou caso - do pronome:

(*) a. Die Geschichte von Antek Pistole ist der Roman, dem in Margarinien wohnte. (Inf. 4)

(*) b. Die Geschichte von Antek Pistole ist der Roman, die aus Margarinien ist. (Inf. 6)

Não se registraram erros relativos à posição verbal. Entretanto, no caso de três orações específicas, verificaram-se especificidades não classificáveis de acordo com a taxonomia anteriormente apresentada. Trata-se das orações construídas pelo aprendiz 1 , que fogem completamente à estrutura das orações relativas e, de fato, foram construídas como orações principais, e da oração $a$ do informante 3 ("Die Geschichte von Antek Pistole ist der Roman, den internet benutzt"), inviável sintática e semanticamente, provavelmente devido a uma compreensão equivocada do significado do correlato "Roman". 197

Assim sendo, observa-se mais uma vez que a posição verbal na oração relativa foi devidamente aprendida pela maior parte dos informantes deste grupo, enquanto que maiores dificuldades foram registradas junto à forma (declinação) do pronome relativo.

\footnotetext{
${ }^{197}$ De acordo com o depoimento dos professores-voluntários, o sentido dessa palavra foi explicitado antes de que os alunos começassem a fazer os exercícios, de acordo com solicitação do pesquisador, tendo como base os resultados da sondagem previamente registrados.
} 


\subsubsection{Atividade D}

No caso da atividade D, solicitou-se aos alunos a redação de um texto de tema livre, com cerca de 150 palavras, no qual surgissem ao menos cinco orações relativas. Serão listadas, a seguir, as orações relativas que figuraram entre cada um dos textos coletados. Alguns alunos elaboraram menos de cinco relativas, a despeito do que se propunha no enunciado.

Informante 1: Este aluno escreveu um texto sobre a experiência de provar diferentes alimentos típicos durante viagens. Tematiza as diferenças de alimentação entre países localizados à beira-mar, países de clima quente e frio. Relaciona alimentação, cultura e práticas culturais e econômicas, como a cultura do arroz no Japão.

(*) a. Ein Sache, das finde ich wichtig ist zu essen typische Lebensmittel in eine Reise.

- Eine Sache, die ich wichtig finde ist es auf einer Reise typische Lebensmittel zu essen.

[Um coisa que eu acho importante é comer alimentos típicos numa viagem.]

Neste exemplo observa-se, à primeira vista, a concentração de dois erros referentes à estrutura oração relativa: troca do gênero do pronome (neutro, em vez de feminino) e a posição do verbo, que não foi situado ao final da sentença. No caso do pronome, nota-se, entretanto, que o próprio correlato está acompanhado do artigo indefinido "ein" (masculino ou neutro), em vez da forma apropriada feminina "eine". Isso revela uma troca de gênero do próprio correlato, de modo que, a partir dessa perspectiva, houve concordância entre correlato e pronome relativo ("ein Sache"/das).

(*) b. Wenn man Reise kann man internazional Lebensmittel gegessen, aber mit Lebensmittel, dem Geographie kommen zu.

- Wenn man reist, kann man internationale Lebensmittel essen, aber mit Lebensmitteln, die mit Geographie kommen (?)

[Quando se viaja, pode-se comer alimentos internacionais, mas com alimentos que vêm com geografia (?)] 
No exemplo acima, considera-se a ocorrência de uma aglomeração de palavras no lugar da oração relativa. A aproximação verbatim ao português poderia sugerir a possibilidade de que o autor da frase tenha tentado escrever sobre alimentos "que vêm com geografia". Entretanto, tratando-se da possibilidade de uma formulação incomum tanto em português quanto em alemão, não se pode oferecer garantias de que essa seja a tradução possível da sentença. Observa-se, no caso, o uso indevido do pronome relativo e o verbo no meio da frase.

Verifique-se o próximo exemplo:

(*) c. Im Land, dem neben See liegt ist man normalaweise Fisch.

- In einem Land, das an der See liegt, isst man normalerweise Fisch. [Num país que fica à beira-mar, come-se normalmente peixe.]

No exemplo acima, registra-se a colocação do verbo de modo adequado, ao final da sentença. $\mathrm{O}$ fato do mesmo informante ter construído orações que ora contêm um verbo bem posicionado, ora não, denota a instabilidade que é própria da interlíngua dos aprendizes. Além disso, pode-se entrever, no plano da pontuação, a falta de vírgula isolando a oração relativa e, no âmbito morfossintático, o pronome relativo em posição de sujeito declinado no dativo, em vez de no nominativo. Um erro semelhante de declinação foi observado no exemplo abaixo, em que o pronome relativo, que deveria estar no feminino singural nominativo, foi inserido no dativo plural.

$\left.{ }^{*}\right)$ d. Lebensmittel kommen auch mit Kultur, denen Leute dort haben.

- Lebensmittel kommen auch mit (der) Kultur, die [die] Leute dort haben. [Alimentos vêm também com [a] cultura que [as] pessoas lá têm.]

(*) e. (...) mit Reis kommt die Arbeitkultur, denen Japanischen haben.

- (...) mit dem Reis kommt die Arbeitskultur, die die Japaner haben. [(...) com o arroz vem a cultura do trabalho que os japoneses têm.]

A produção do informante 1 na atividade D denota a presença de dificuldades referentes à contrução das orações relativas. Em termos de compreensibilidade, tem-se 4 orações cujo sentido pode ser depreendido sem maiores dificuldades, e uma que oferece travas à sua compreensão. Nas 5 construções, deu-se a inserção de pronomes relativos 
indevidos, contabilizando-se erros de gênero, número e caso, e 2 ocorrências de verbos corretamente situados ao final da frase. Essas constatações reiteram o que se pôde observar de seu desempenho nas demais atividades em que cabia ao aluno produzir as próprias frases. $\mathrm{Na}$ atividade $\mathrm{B}$, o aluno construiu apenas 1 frase com o pronome relativo devidamente flexionado ("Wir haben drei Kinder, die Mechnikel werden wollten"). $\mathrm{Na}$ atividade $\mathrm{C}$, deram-se aglomerados de palavras, sem a construção de orações relativas, nas duas sentenças. Apenas na atividade A, de natureza reprodutiva, o aluno forneceu as respostas corretas. $\mathrm{Na}$ atividade $\mathrm{B}$, apesar dos erros relativos aos pronomes, o aluno situou os verbos ao final da frase, fato que não se repetiu nas orações inseridas na produção textual. Em resumo, na atividade D o aluno não produziu uma única oração com ausência de erros primários.

Informante 2: Escreveu um texto sobre seu trabalho numa empresa de moda e as diferentes tarefas que realiza em seu dia-a-dia, incluindo-se as atividades extras que necessita desempenhar durante as férias de sua chefe.

a. Ich arbeite in eine Mode Firma, die 1,5 Jahre alt ist.

- Ich arbeite in einer Modefirma, die 1,5 Jahre alt ist.

[Eu trabalho numa empresa de moda que tem 1,5 ano de idade.]

(*) b. Ich arbeite in die Marketing Abteilung, in dem viele arbeite gibt.

- Ich arbeite in der Marketingabteilung, in der es viel Arbeit gibt. [Eu trabalho no departamento de marketing, no qual há muito trabalho.]

c. Ich habe viele aufgaben, die sehr verschiedene sind.

- Ich habe viele Aufgaben, die sehr verschieden sind. [Eu tenho muitas tarefas que são muito diferentes.]

d. Ich muss die Produkten für unser Home Pages suchen, die gute Preis und Stock haben.

- Ich muss die Produkte für unsere Homepages suchen, die gute Preise und ? haben.

[Eu preciso procurar os produtos para nossas homepages que tenham bom preço e ?]

e. Meine Chefin ist jetzt im Urlaub, und ich habe viele mehr Dinge zu machen, die sie mir gegeben hat.

- Meine Chefin ist jetzt im Urlaub, und ich habe viel mehr Dinge zu tun, die sie mir gegeben hat.

[Minha chefe está de férias agora, e eu tenho muitas mais coisas para 
fazer que ela me "deu” (atribuiu/passou).]

No caso das 5 sentenças elaboradas pelo informante 2 ao longo de seu texto, observa-se o posicionamento adequado do verbo ao final da frase em todas as ocorrências. Em quatro das sentenças (a, c, d, e), a correspondência correlato-pronome relativo é adequada e o pronome se encontra devidamente flexionado. Em um caso específico (frase b), deu-se um erro de gênero do pronome, corretamente declinado no dativo, mas em uma forma que pode ser depreendida como masculina ou neutra ("dem") em vez de feminina (“der"). Assim, $80 \%$ das orações construídas pelo informante 2 estão corretas e o único erro primário cometido é referente à declinação do pronome relativo.

Informante 3: Seu texto versa acerca das bebidas britânicas, após considerar o Reino Unido o melhor país para se conhecer. Compara preços de bebidas e pondera o uísque como alternativa à cerveja para aqueles que o prefiram.

(*) a. Die Besten platz in die welt zu kennen ist UK, die gute bier haben.

- Der beste Platz in der Welt zum Kennenlernen ist das Vereinigte Königreich, das gutes Bier hat.

[O melhor lugar no mundo para se conhecer é o Reino Unido, que tem boa cerveja.]

b. Guiness ist ein gut bier zu probieren, das es swartzes bier ist.

- Guinness ist ein gutes Bier zum Probieren, das ein schwarzes Bier ist. [Guinness é uma boa cerveja para se provar que é uma cerveja preta.]

c. Man kann whisky trinken, der mehr tradizionale ist.

- Man kann Whisky trinken, der traditioneller ist. [Pode-se tomar uísque, que é mais tradicional.]

d. Andere alternative ist einige Getränke von Europa, die billiger aus Brasilien ist.

- Eine Alternative sind einige Getränke aus Europa, die billiger sind als in Brasilien.

[Uma alternativa são algumas bebidas da Europa que são mais baratas que no Brasil.] 
Malgrado a presença de diversos erros secundários, o informante 3 demonstrou domínio das ferramentas específicas de construção das orações relativas no nominativo. Todas elas apresentam o verbo ao final, e, com exceção da primeira sentença (a), em todas as ocorrências o pronome relativo indicado foi o correto. Entretanto, chama atenção a ausência de experimentação com outros casos que não o nominativo, tendo-se mantido um padrão de sentenças explicativas com o verbo "é" ("Guiness é uma boa cerveja para se provar, que é preta") nos três últimos exemplos. $75 \%$ de suas orações relativas estão corretas, tendo-se registrado uma oração incorreta. No caso dessa oração, observa-se que o aluno não identificou gramaticalmente o correlato ("UK"/"das Vereinigte Königreich"), tendo concordado o pronome relativo "die" (aqui, feminino nominativo) com sua indicação "Die besten platz in die welt" ["der beste Platz in der Welt"], onde trocou uma forma masculina por uma feminina.

Informante 4: $\mathrm{O}$ informante inicia seu relato mencionando suas duas irmãs que vivem em outra cidade. Narra algumas atividades realizadas durante um passeio com elas e termina mencionando a fuga de sua cadela.

a. Ich habe zwei Schwestern, die elf Jahre sind.

- Ich habe zwei Schwestern, die elf Jahre alt sind. [Eu tenho duas irmãs que têm onze anos.]

b. Sie wohnen bei meiner Mutter, die in Santos wohnt. [Eles moram com minha mãe que mora em Santos.]

(*) c. Letztem Mal dass ich ihr besucht habe, habe ich Eintrittkarten gekauft, die für einen Kinder Film waren.

- Das letzte Mal, das ich sie besucht habe, habe ich Eintrittskarten gekauft, die für einen Kinderfilm waren.

[Da última vez que eu a visitei, comprei entradas que eram para um filme infantil.]

d. Das Popcorn, das wir gekauft haben war schlecht.

- Das Popcorn, das wir gekauft haben, war schlecht. [A pipoca que nós compramos estava/era ruim.]

e. Unsere Hundin, die zwei Wochen alt ist, ist weg gelaufen.

[Nossa cachorra, que tem duas semanas de idade, fugiu.] 
O informante 4 elaborou cinco períodos com orações relativas. Três deles mostram-se perfeitos; em um caso, observa-se a falta de vírgula ao final da oração relativa, separando-a da principal. Em apenas um exemplo, houve um erro junto ao pronome ("dass" em vez de "das"). Devido à semelhança fonética, é possível que se trate de um erro ortográfico. Entretanto, pelo fato de "dass" corresponder à conjunção "que", existiria a possibilidade de que a aluna tivesse confundido o "que" pronome relativo com o "que" conjuncional. Assim, não é possível emitir um parecer absoluto quanto a essa ocorrência.

Informante 5: O aluno escreveu um resumo do romance Grande Sertão: Veredas, de Guimarães Rosa.

a. "Grande Sertão: Veredas" ist ein brasilianisches Buch, das ich sehr gern mag.

[“Grande Sertão: Veredas” é um livro brasileiro do qual eu gosto muito.]

b. Der Schriftsteller, der viele andere Bücher geschreiben hat, heißt Guimarães Rosa.

- Der Schriftsteller, der viele andere Bücher geschrieben hat, heißt Guimarães Rosa.

[O autor, que escreveu muitos outros livros, chama-se Guimarães Rosa.]

c. Riobaldo ist der Erzähler, der seine eigene Geschichte erzählt.

[Riobaldo é o narrador que conta sua própria história.]

d. Einmal hat er ein anderer "jagunço" kennengelernt, Diadorim, in den er sich verliebt hat.

- Einmal hat er einen anderen "jagunço" kennengelernt, Diadorim, in den er sich verliebt hat.

[Certa vez ele conheceu um outro "jagunço", Diadorim, pelo qual ele se apaixonou.

e. Aber dieses Buch ist auch über andere Themen, die sehr interessante sind.

- Aber dieses Buch ist auch über andere Themen, die sehr interessant sind. [Mas este livro também é sobre outros temas que são muito interessantes.] 
O informante 5 construiu 5 orações relativas que não apresentam erros no tocante às idiossincrasias dessa estrutura. Erros secundários foram registrados e corrigidos, mas não influíram na produção das relativas.

Informante 6: $\mathrm{O}$ aluno relata a experiência de ter conhecido simpáticos cidadãos turcos na Alemanha, um comerciante e um taxista.

a. Der erste, war der besitzer eine kleine Spätkauf, der an Fußballspieler werden zu sein träumte.

- Der erste war der Besitzer eines kleinen Spätkaufs, der davon träumte, Fussballspieler zu werden.

[O primeiro era o proprietário de uma pequena loja de conveniência que sonhava tornar-se jogador de futebol.]

b. Eine sehr gute Unterhalterin, die auf Polen studierte.

- Eine sehr gute Unterhalterin, die in Polen studierte.

[Uma? muito boa, que estudava na Polônia.]

c. Der letzte war der Taxifahrer, ein hoflicher mann, der ein bischen müde von Verkehr war.

- Der letzte war der Taxifahrer, ein höflicher Mann, der ein bisschen müde vom Verkehr war.

[O último era o taxista, um homem cortês que estava um pouco cansado do trânsito.]

d. und für sein junge Sohn sorgt.

- und für seinen jungen Sohn sorgt.

[e que cuida de seu jovem filho.]

(*) e. Das ist etwas, dass wir brasilianer auch machen.

- Das ist etwas, was/das wir Brasilianer auch machen.

[Isso é algo que nós, brasileiros, também fazemos.]

As quatro primeiras orações formuladas pelo sexto informante apresentam corretamente os elementos que caracterizam a oração relativa. O erro registrado na sentença "a" envolve uma estrutura que ainda é desconhecida dos alunos que se encontram entre os níveis A2 e B1 do QECR (“... der Besitzer..., der davon träumte, Fußballspieler zu werden"). Por isso, deve-se considerar o fato de que o aluno procurou situar o verbo ao final da frase. No último exemplo (e), deu-se o mesmo erro da 
informante 5, o emprego de "dass" em vez de "das", consistindo num erro dúbio que aponta para duas possíveis direções, como anteriormente mencionado (ortográfica ou morfossintática).

\subsubsection{Balanço dos dados do Grupo A}

Com vistas a facilitar a visualização dos dados e os pesos dos diferentes tipos de erros, bem como do critério compreensibilidade das produções dos alunos, as informações serão quantificadas nas tabelas que se seguem. Serão listadas as seguintes informações nas colunas: atividade em questão (B, C ou D), identificação do informante (de 1 a 6), total de orações relativas construídas pelo informante na atividade, total de orações consideradas compreensíveis dentre esse montante, erros de posição do verbo, erros concentrados no pronome relativo, classificados em erros de gênero, número e caso do pronome, e pontuação (ausência de vírgulas isolando as orações relativas, aplicável somente à atividade $\mathrm{D}$, uma vez que, nos exercícios B e C, as vírgulas já constavam da diagramação do exercício). O objetivo da construção das tabelas não é o de sobrepor um suposto caráter iminentemente quantitativo a esta pesquisa, que é iminentemente qualitativo-interpretativista, ainda que se adote um paradigma misto quantitativo/qualitativo. Pretende-se, mais que isso, buscar apoio no caráter imagético das tabelas, que permitem uma visualização resumida e privilegiada das ocorrências contabilizadas durante a análise dos erros.

Tabela 5 - Balanço quantitativo da atividade B, Grupo A

\begin{tabular}{|c|c|c|c|c|c|c|c|c|}
\hline atividade & informante & $\begin{array}{l}\text { total } \\
\text { frases }\end{array}$ & compreens. & $\begin{array}{l}\text { verbo } \\
\text { pos. }\end{array}$ & $\begin{array}{l}\text { pron. } \\
\text { gen. }\end{array}$ & $\begin{array}{l}\text { pron. } \\
\text { num. }\end{array}$ & $\begin{array}{l}\text { pron. } \\
\text { caso }\end{array}$ & pontuação \\
\hline \multirow{5}{*}{ B } & 1 & 4 & 4 & 0 & 1 & 0 & 0 & n/a \\
\cline { 2 - 9 } & 2 & 5 & 5 & 0 & 1 & 0 & 0 & n/a \\
\cline { 2 - 9 } & 3 & 5 & 5 & 2 & 1 & 0 & 2 & n/a \\
\cline { 2 - 9 } & 4 & 5 & 5 & 0 & 1 & 0 & 2 & n/a \\
\cline { 2 - 9 } & 5 & 5 & 5 & 0 & 1 & 0 & 0 & n/a \\
\cline { 2 - 9 } & 6 & 5 & 5 & 0 & 1 & 0 & 0 & n/a \\
\hline
\end{tabular}

$\mathrm{Na}$ tabela 5, referente aos resultados registrados junto à atividade $\mathrm{B}$, pode-se visualizar, inicialmente, a onipresença de construções consideradas compreensíveis no 
conjunto da produção dos seis informantes. Chama a atenção, igualmente, o fato de apenas um informante (3) ter cometido erros referentes à posição do verbo nas frases (em duas de um total de cinco). De mais difícil catalogação foi um erro cometido por quatro informantes $(3,4,5$ e 6$)$ na segunda frase construída. Nos quatro exemplos, os alunos construíram frases sob a premissa de que o pronome relativo indicado, "der", pudesse funcionar como sujeito da oração relativa. Entretanto, sendo o correlato "mit meiner Ärztin", um feminino (no dativo), o pronome referente "der" deveria ser interpretado como um dativo feminino. No caso de ser um nominativo, tratar-se-ia de um masculino; portanto, inassociável com o correlato fornecido. Esse erro poderia ser considerado de gênero (masculino em vez de feminino) ou de caso (nominativo em vez de dativo). Na tabela, esses erros foram classificados como de gênero, já que o pronome "der" foi empregado como sujeito das orações. Um erro não contabilizado na tabela foi o cometido pelo informante 1 na sentença 2, a inclusão de um pronome pessoal após o pronome relativo indicado ("Ich rede immer mit meiner Ärztin, der sie wie ein Schauspilare lauft'), dada a sua especificidade.

Tabela 6 - Balanço quantitativo da atividade C, Grupo A

\begin{tabular}{|c|c|c|c|c|c|c|c|c|}
\hline atividade & informante & $\begin{array}{l}\text { total } \\
\text { frases }\end{array}$ & compreens. & $\begin{array}{l}\text { verbo } \\
\text { pos. }\end{array}$ & $\begin{array}{l}\text { pron. } \\
\text { gen. }\end{array}$ & $\begin{array}{l}\text { pron. } \\
\text { num. }\end{array}$ & $\begin{array}{l}\text { pron. } \\
\text { caso }\end{array}$ & pontuação \\
\hline \multirow{5}{*}{ C } & 1 & 2 & 1 & \multicolumn{3}{|c|}{ não construiu orações relativas } & n/a \\
\cline { 2 - 9 } & 2 & 2 & 2 & 0 & 0 & 0 & 0 & $\mathrm{n} / \mathrm{a}$ \\
\cline { 2 - 10 } & 3 & 2 & 1 & 0 & 0 & 0 & $\mathbf{1}$ & $\mathrm{n} / \mathrm{a}$ \\
\cline { 2 - 9 } & 4 & 2 & 1 & 0 & 0 & 0 & $\mathbf{1}$ & $\mathrm{n} / \mathrm{a}$ \\
\cline { 2 - 9 } & 5 & 2 & 2 & $\mathbf{0}$ & 0 & 0 & 0 & $\mathrm{n} / \mathrm{a}$ \\
\cline { 2 - 9 } & 6 & 2 & 2 & 0 & 1 & 0 & $\mathbf{0}$ & $\mathrm{n} / \mathrm{a}$ \\
\hline
\end{tabular}

Um balanço dos resultados da atividade $\mathrm{C}$ nos mostra a presença de problemas de compreensibilidade em três das doze orações construídas pelos alunos. No caso do informante 1, não foram construídas orações relativas, e apenas uma das construções (sentença b) pode-se considerar compreensível. Os informantes 3 e 4 também construíram, cada um, uma oração sem sentido, ambos os casos registrados na sentença a. Trata-se provavelmente de um problema de compreensão do correlato "Roman" (romance). Entretanto, como já se documentou neste texto, foi pedido aos professoresvoluntários que esclarecessem aos alunos, antes de lhes entregarem as atividades, o significado desse vocábulo (no caso de Schritte International 5, "der Roman" já havia inclusive aparecido algumas páginas antes na mesma lição - mais precisamente, na 
página 24). Aparentemente, a informação não ficou clara para todos os informantes, e não será possível investigar, junto a eles, a raiz desse problema. Observaram-se, ainda, um caso de troca de gênero do pronome relativo, e dois de troca de caso. À exceção do informante 1, que não construiu orações relativas, não foram computados erros de posição verbal e registrou-se uma maior ocorrência de erros de caso, como na atividade B, confirmando a observação feita durante a descrição da estrutura, no capítulo 1 do trabalho, de que a flexão de caso, ausente no português, oferece dificuldades especiais aos aprendizes brasileiros.

Tabela 7 - Balanço quantitativo da atividade D, Grupo A

\begin{tabular}{|c|c|c|c|c|c|c|c|c|}
\hline atividade & informante & $\begin{array}{l}\text { total } \\
\text { frases }\end{array}$ & compreens. & $\begin{array}{l}\text { verbo } \\
\text { pos. }\end{array}$ & $\begin{array}{l}\text { pron. } \\
\text { gen. }\end{array}$ & $\begin{array}{l}\text { pron. } \\
\text { num. }\end{array}$ & $\begin{array}{l}\text { pron. } \\
\text { caso }\end{array}$ & pontuação \\
\hline \multirow{6}{*}{ D } & 1 & 4 & 3 & 3 & 0 & 1 & 2 & 2 \\
\cline { 2 - 9 } & 2 & 5 & 5 & 0 & 1 & 0 & 0 & 0 \\
\cline { 2 - 9 } & 3 & 4 & 5 & 0 & 0 & 0 & 0 & 0 \\
\cline { 2 - 9 } & 4 & 5 & 5 & 0 & 0 & 0 & 0 & 1 \\
\cline { 2 - 9 } & 5 & 5 & 5 & 0 & 0 & 0 & 0 & 0 \\
\cline { 2 - 9 } & 6 & 5 & 5 & 0 & 0 & 0 & 0 & 0 \\
\hline
\end{tabular}

A produção dos alunos na atividade $\mathrm{D}$, sob a forma de produções textuais de temática livre incluindo orações relativas, revela alguns aspectos do processo de ensinoaprendizagem dessa estrutura por parte dos informantes e completa as informações discutidas às margens das tabelas anteriores. O informante 1 se confirma como aquele que maiores dificuldades apresentou no tocante à produção de orações relativas, tendo formulado uma sentença não compreensível e cometido 3 erros de posição verbal em um total de 4 frases. Os demais participantes não cometeram erros de posição verbal. Apenas os informantes 1 e 2 cometeram erros de flexão pronominal ${ }^{198}$, mas é notório o fato de que os alunos que não cometeram erros construíram uma maioria de orações com pronome relativo apenas no nominativo ${ }^{199}$. Isso põe uma vez mais em evidência o

\footnotetext{
198 Não se contabilizou a formulação "ein Sache, das..." do informante 1 na sentença a como erro de gênero, uma vez que o desconhecimento do gênero do substantivo "Sache" (feminino) pode ser considerado secundário. A questão primariamente considerada, aqui, é a concordância de gênero com o correlato. O aluno, no caso, utilizou um artigo indefinido neutro (forma idêntica à masculina) para acompanhar o substantivo "Sache", e empregou um pronome relativo neutro.

${ }^{199}$ Uma observação encontrada numa tese a respeito de gramática latina nos dá, por analogia, algumas pistas importantes acerca dessa questão, mesmo que não se trate de um trabalho de língua alemã. Ruy (2006, p. 34) cita Murachco e afirma: "Nominativo 'é o caso da denominação, da nomeação, da identidade, da identificação. [...] Há também quem afirme que o nominativo não é um caso [...] a forma
} 
critério caso/declinação como foco de dificuldade para os aprendizes, quer seja devido ao seu emprego incorreto em algumas atividades, quer seja pela ausência de construções empregando o acusativo e o dativo.

A ocorrência de casos em que um mesmo aluno construiu ora orações relativas com o verbo corretamente situado ao final, ora orações em que o verbo se encontrava em outra posição, não considerada adequada segundo os critérios de construção de ditas orações, aponta para a instabilidade que é própria da interlíngua dos aprendizes. Assim, Alvarez (2002, s/n) nos lembra Brabo (2001), segundo quem

a interlíngua constitui uma competência lingüístico-comunicativa que o aprendiz de LE manifesta em sua produção, marcada pela variabilidade num percurso com avanços, regressões, instabilidades e possíveis fossilizações até o estágio final. [sic]

Além disso, é importante relembrar os postulados da Teoria da Processabilidade, resenhados no capítulo 1.2 de fundamentação teórica deste trabalho, que apontam para a maior dificuldade representada aos aprendizes não-nativos de alemão pelas orações subordinadas, com o verbo situado ao final.

Quanto à significativa presença de erros de flexão dos pronomes relativos, em grande parte dos casos associada à flexão de caso, circunstância morfossintática que situa as orações relativas um passo além das subordinadas introduzidas por conjunção em termos de dificuldade, Quites (1997, p. 21) nos lembra que "em relação a alunos de Alemão como LE nativos de língua portuguesa, A. FRANCO (1986, p. 33) descreve que '... os aprendentes [...] parecem não atribuir a respectiva importância funcional aos acidentes flexionais do alemão". ${ }^{200}$ Isso se deve, como especificado no capítulo desta

do nominativo seria a forma-referência" (MURACHCO, 2000, p. 88-92, apud RUY, 2006, p. 34). Fonte: RUY, M. L. Formação de palavras - Livro VIII da gramática de Varrão. Tese (Doutorado em Letras Clássicas). São Paulo: FFLCH-USP, 2006. Desse modo, e num contexto de ensino-aprendizagem (alemão por aprendizes brasileiros) em que as declinações efetivamente representam um desafio, observa-se que a assimilação do nominativo é a que oferece menores desafios aos alunos, por representar o "nome" das palavras, a forma que as identifica e a primeira que se aprende. Assim, a construção de orações relativas no nominativo se apóia em formas do pronome relativo já dominadas pelos alunos, uma vez que coincidem com as formas dos artigos definidos no nominativo, abrindo espaço para a formulação de orações qualificativas simples com verbo de ligação e adjetivo em função predicativa.

${ }^{200}$ A autora cita FRANCO, A. C. Uma análise de erros no âmbito do português-alemão; análise com base na produção escrita de aprendentes portugueses de alemão como segunda língua. Tese (Doutorado em Linguística Geral). Porto: Faculdade de Letras do Porto, 1986. 
dissertação dedicado à descrição das orações relativas do alemão-padrão, à ausência da flexão de caso (ao menos via desinências, já que alguma correntes gramaticais os identificam no português por analogia funcionalista com o latim, como se nota em passagens de CASTILHO, 2010) na língua portuguesa e à dificuldade geral do aluno em assimilar tanto suas formas quanto sua real utilidade. É também por esse motivo que, na produção livre dos informantes (atividade D), houve uma notória preponderância de orações no nominativo:

Tabela 8 - Orações relativas no nominativo, Grupo A, Atividade D

\begin{tabular}{|c|c|c|}
\hline $\begin{array}{c}\text { Informante } \\
\mathbf{1}^{\mathbf{2 0 1}}\end{array}$ & Or. relativas construídas & Orações no nominativo \\
\hline $\mathbf{2}$ & 4 & 3 \\
\hline $\mathbf{3}$ & 5 & 4 \\
\hline $\mathbf{4}$ & 5 & 4 \\
\hline $\mathbf{5}$ & 5 & 3 \\
\hline $\mathbf{6}$ & 5 & 3 \\
\hline Total & 28 & 21 \\
\hline
\end{tabular}

Levanta-se, assim, a hipótese de que o nominativo, enquanto "nome da palavra", forma do artigo encontrada nas obras lexicográficas e primeira forma aprendida pelos alunos em cursos de ALE, é o caso declinatório com o qual os alunos demonstram ter mais familiaridade e maior segurança ao manipulá-lo ${ }^{202}$. Além disso, se retomarmos a questão da necessidade de memorização das formas dos pronomes relativos nos três casos para a construção satisfatória de orações relativas no nominativo, acusativo e dativo, pode-se afirmar que as formas do nominativo, dominadas pelos alunos desde sua apresentação no estágio A1.1 do curso, é a que menos exige esforços e cujo registro possivelmente se concretizou na memória de longa duração meses antes da realização destas atividades. Assim, o input compreensível representado pela apresentação das

\footnotetext{
${ }^{201}$ No caso do informante 1 , houve o emprego de pronomes relativos declinados em outros casos, mas sempre em função de sujeito (nominativo).

${ }^{202}$ No item 1.1.3, fez-se referência ao fenômeno da simplificação (Kleppin, 1998), que consiste em situações nas quais o aluno evita construções complexas, como subordinadas, ou deixa de conjugar verbos. Evitar o acusativo e o dativo é um cenário que pode remeter a esse conceito.
} 
formas dos pronomes relativos no acusativo e no dativo oferece maiores dificuldades para a memória, além da exigência do conhecimento de um entorno sintático mais complexo que os ambiente (verbos, preposições e colocações que rejam o acusativo e o dativo etc.). Apesar disso, convém mencionar as palavras de Dürscheid, que apontam para o fato de que o nominativo é, em si, o mais frequente dos casos da língua alemã ${ }^{203}$ :

Der Nominativ ist der Kasus, der im Deutschen die höchste Frequenz hat. Er ist am ehesten von Rollenanhebungen betroffen [...] Daraus folgt, dass der Nominativ die verschiedensten semantischen Rollen aufnehmen kann bzw. aufnehmen muss, wenn kein anderer Kasus vorhanden ist. Der Dativ dagegen ist in seinem Auftreten am stärksten restringiert. ${ }^{204}$ (DÜRSCHEID, 1999, p. 176).

Essa questão será retomada mais adiante.

Finalmente, objetiva-se proceder a uma classificação dos erros dos informantes a partir da tipologia que nos apresenta Figueiredo, F. (2004), e que se subdivide em três tipos maiores, a saber, os interlinguais (influência da língua materna do aprendiz), os intralinguais, que não derivam dessa influência, e, por fim, os induzidos, resultados de uma forma inadequada de se ensinar a LE. Neste trabalho, não consideraremos a

\footnotetext{
${ }^{203}$ Não faz parte do escopo deste trabalho palmilhar com profundidade a questão das comparações que podem ser estabelecidas entre a interlíngua em construção de aprendizes adultos e o processo de aquisição de linguagem por parte de crianças nativas, mas convém comentar que, como nos mostra Figueiredo, F. (1995), embora essa questão não esteja assentada de forma conclusiva, com relevante dissensão entre teóricos, importantes autores como Cooper e Corder apontaram as semelhanças existentes entre os dois processos e seus produtos, com as crianças nativas e os aprendizes não-nativos adultos construindo sentenças semelhantes e que não são formuladas por nativos adultos da língua-alvo. Figueiredo menciona Taylor, segundo quem ambos os processos apresentam como características suas a generalização e a analogia. Nesse ínterim, convém lembrar o trabalho de Rottweiler (1993, p. 133) sobre a aquisição das orações relativas por parte de crianças nativas, e algumas de suas considerações: "Auffällig ist, dass die meisten Relativpronomen entweder im Nominativ, $d . h$. als Subjekt oder oder in einer kasusneutralen Form auftreten [...] Vor allem d-Pronomen sind meist Subjektspronomen. [...] Die meisten Pronomen also, die morphologisch für Kasus markiert werden können, treten im Nominativ auf; die übrigen Pronomen können gar keine Kasusmarkierung tragen. Es sieht so aus, als würden Kinder eindeutige Kasusmarkierungen vermeiden und bevorzugt Nominativformen oder generalisierende Pronomen verwenden, wenn es möglich ist." Ao levantar esta questão, não pretendo abandonar a hipótese de que formulações no nominativo, no âmbito das orações relativas, são menos dificultosas para aprendizes brasileiros, que conhecem desde suas primeiras aulas de ALE as formas der/die/das/die, e têm menos familiaridade e memorização das demais declinações dos pronomes relativos alemães. Entretanto, esse cruzamento de informações serve para demonstrar que, associados a esta questão levantada por esta hipótese, existem outros fatores que determinam a maior incidência do acusativo entre os casos alemães, tanto na linguagem usada por adultos (DÜRSCHEID, 1999) quanto naquela desenvolvida por crianças.

204 “O nominativo é o caso que tem a maior frequência no alemão. É o mais afetado por aumentos de funções [...]. Daí tem-se que o nominativo pode, ou melhor, deve assumir um número mais variado de funções semânticas quando nenhum outro caso estiver presente. $\mathrm{O}$ dativo, ao contrário, é mais fortemente restrito em sua ocorrência."
} 
possibilidade de ocorrência de erros induzidos, uma vez que não se observaram as práticas docentes em sala de aula durante os cursos em que ocorreram as coletas de dados, não sendo esta pesquisa intervencionista. Assim, será verificada a possibilidade de ocorrência de erros intralinguais e interlinguais. Esse critério de classificação se mostra importante, primeiramente, porque uma parcela significativa dos erros cometidos pelos alunos poderiam ser atribuíveis a influências da LM. Entretanto, como poderá ser observado mais adiante, a análise de orações relativas em alemão elaboradas por aprendizes brasileiros dá lugar a importantes questionamentos acerca da possibilidade de estarmo-nos deparando com erros intra ou interlinguais.

Por esse motivo, antes de proceder à análise dos erros propriamente dita, faz-se importante registrar uma dificuldade inerente à classificação de erros primários de orações relativas em uma ou outra das duas categorias acima explicitadas. Isso porque, no tocante a esses erros, dá-se, amiúde, o registro de diversas ocorrências em que se poderia tratar tanto de um erro intralingual quanto de um interlingual. Observe-se o seguinte exemplo:

(*) Ich rede immer mit meiner Ärztin, der ist die besten in mein land. (Grupo A, Atividade B, Inf. 3, frase 2).

Se focarmos, de forma a ilustrar o exemplo, no erro primário referente à posição do verbo, teremos de nos deparar com duas possibilidades: primeiramente, observa-se que o posicionamento do verbo por parte do aluno logo após o sujeito remete à posição canônica dos elementos em uma sentença declarativa portuguesa (língua SVO onde também é canônica a ordem sujeito-verbo-predicativo, exceto ocorrências em que o objeto ou predicativo apareçam na forma de pronomes oblíquos), o que daria margem à sua interpretação como erro interlingual. Entrementes, se considerarmos o fato de que o alemão é uma língua V2, na qual o verbo finito surge na segunda posição sintática da frase, e relevando-se o fato de que essa estrutura é uma das primeiras que são metalinguisticamente explicitadas aos alunos em cursos de ALE mediante a adoção dos LDs com que se trabalha nesta pesquisa, é de se considerar lógica a possibilidade de uma ocorrência de erro intralingual, num caso de ordem indevida de palavras motivada pela interferência de outra estrutura mais basilar da própria LE. Corroboram neste sentido as observações oriundas da Teoria da Processabilidade, que situam a aquisição 
da ordem de palavras própria das orações subordinadas ao final de um continuum, e a aquisição da ordem V2 várias etapas antes, podendo tratar-se, portanto, de um caso de instabilidade na assimilação da estrutura das subordinadas e remissão à estrutura anteriormente assimilada numa fase predecessora (e sua generalização e extensão a outros contextos gramaticais). Assim, a condução desta tentativa de análise e classificação de erros não conduzirá necessariamente a uma catalogação fixa e precisa, servindo, também, para o levantamento de hipóteses e questões que permanecerão, em alguns casos, e dada a sua natureza, abertas para ponderações e reflexões que não se encerram em si mesmas.

Observe-se a tabela:

Tabela 9 - Erros intra e interlinguísticos na produção geral do Grupo A

\begin{tabular}{|c|c|c|c|}
\hline $\begin{array}{c}\text { Identificação } \\
\text { (Atividade/ } \\
\text { Informante/ } \\
\text { Frase) }\end{array}$ & Erro analizado & $\begin{array}{c}\text { Intra/ } \\
\text { Inter } \\
\text { (IA/IE/ } \\
\text { ?) }\end{array}$ & Subtipo \\
\hline $\mathrm{B} / 1 / 1$ & $\begin{array}{l}\text { „Das ist der Mann, den ich ein Kind } \\
\text { habe." }\end{array}$ & $?$ & \\
\hline $\mathrm{B} / 1 / 2$ & $\begin{array}{l}\text { "Ich rede immer mit meiner Ärztin, der } \\
\text { sie wie ein Schauspilare lauft." }\end{array}$ & $?$ & \\
\hline $\mathrm{B} / 2 / 4$ & $\begin{array}{l}\text { "In der Sprachenschule, in dem wir } \\
\text { lernen, die gute Lehrer hat." }\end{array}$ & $?$ & \\
\hline $\mathrm{B} / 3 / 1$ & $\begin{array}{l}\text { "Das ist der Mann, den ein großes Auto } \\
\text { hat." }\end{array}$ & $?$ & \\
\hline $\mathrm{B} / 3 / 2$ & $\begin{array}{l}\text { "Ich rede immer mit meiner Ärztin, der } \\
\text { ist die besten in mein land." }\end{array}$ & $?$ & \\
\hline $\mathrm{B} / 3 / 2$ & $\begin{array}{l}\text { "Ich rede immer mit meiner Ärztin, der } \\
\text { ist die besten in mein land. " }\end{array}$ & $?$ & \\
\hline $\mathrm{B} / 3 / 4$ & $\begin{array}{l}\text { "In der Sprachenschule, der **** ist } \\
\text { wir lernen" }\end{array}$ & $?$ & \\
\hline $\mathrm{B} / 3 / 5$ & $\begin{array}{l}\text { "Margarinien ist ein kleines Land, das } \\
\text { Antek Pistole wohnte." }\end{array}$ & $?$ & \\
\hline $\mathrm{B} / 4 / 2$ & $\begin{array}{l}\text { "Ich rede immer mit meiner Ärztin, der } \\
\text { immer um mich gekummert hat." }\end{array}$ & $?$ & \\
\hline $\mathrm{B} / 4 / 3$ & $\begin{array}{l}\text { „Wir haben drei Kinder, denen an der } \\
\text { Porto Seguro Schule besuchen." }\end{array}$ & $?$ & \\
\hline $\mathrm{B} / 4 / 4$ & $\begin{array}{l}\text { "In der Sprachenschule, der bei wir } \\
\text { lernen, heißt } * * * * . “\end{array}$ & IA & $\begin{array}{l}\text { ordem indevida de } \\
\text { palavras }\end{array}$ \\
\hline $\mathrm{B} / 5 / 2$ & $\begin{array}{l}\text { "Ich rede immer mit meiner Ärztin, der } \\
\text { mein Nachbar auch ist." }\end{array}$ & $?$ & \\
\hline $\mathrm{B} / 6 / 2$ & $\begin{array}{l}\text { "Ich rede immer mit meiner Ärztin, der } \\
\text { eine sehr interessante Frau ist." }\end{array}$ & $?$ & \\
\hline
\end{tabular}




\begin{tabular}{|c|c|c|c|}
\hline $\mathrm{C} / 1 / \mathrm{a}$ & $\begin{array}{l}\text { "Die Geschichte von Antek Pistole ist } \\
\text { der Roman, Antek Pistole, ist der } \\
\text { Roman von die Geschichte." }\end{array}$ & IA & aglomeração \\
\hline $\mathrm{C} / 1 / \mathrm{b}$ & $\begin{array}{l}\text { "Zwischen Europa und Asien liegt die } \\
\text { Türkei, Türkei liegt zwischen Europa } \\
\text { und Asien." }\end{array}$ & IA & aglomeração \\
\hline $\mathrm{C} / 3 / \mathrm{a}$ & $\begin{array}{l}\text { "Die Geschichte von Antek Pistole ist } \\
\text { der Roman, den internet benutzt." }\end{array}$ & $?$ & \\
\hline $\mathrm{C} / 4 / \mathrm{a}$ & $\begin{array}{l}\text { "Die Geschichte von Antek Pistole ist } \\
\text { der Roman, dem in Margarinien } \\
\text { wohnte." }\end{array}$ & $?$ & \\
\hline $\mathrm{C} / 6 / \mathrm{a}$ & $\begin{array}{l}\text { "Die Geschichte von Antek Pistole ist } \\
\text { der Roman, die aus Margarinien ist." }\end{array}$ & $?$ & \\
\hline $\mathrm{D} / 1 / \mathrm{a}$ & $\begin{array}{l}\text { „Ein Sache, das finde ich wichtig ist zu } \\
\text { essen [...] “ }\end{array}$ & $?$ & \\
\hline $\mathrm{D} / 1 / \mathrm{b}$ & $\begin{array}{l}\text { „[...] aber mit Lebensmittel, dem } \\
\text { Geographie kommen zu." }\end{array}$ & $?$ & \\
\hline $\mathrm{D} / 1 \mathrm{c}$ & „Im Land, dem neben See liegt [...]“ & $?$ & \\
\hline $\mathrm{D} / 1 / \mathrm{d}$ & $\begin{array}{l}\text { „Lebensmittel kommen auch mit Kultur, } \\
\text { denen Japanischen haben." }\end{array}$ & $?$ & \\
\hline $\mathrm{D} / 1 / 3$ & $\begin{array}{l}\text { „Mit Reis kommt die Arbeitkultur, denen } \\
\text { Japanischen haben“. }\end{array}$ & $?$ & \\
\hline $\mathrm{D} / 2 / \mathrm{b}$ & $\begin{array}{l}\text { "Ich arbeite in die Marketing Abteilung, } \\
\text { in dem viele Arbeite gibt." }\end{array}$ & $?$ & \\
\hline $\mathrm{D} / 3 / \mathrm{a}$ & ,[...] UK, die gute bier haben." & $?$ & \\
\hline $\mathrm{D} / 4 / \mathrm{c}$ & $\begin{array}{l}\text { „Letztem Mal dass ich ihr besucht habe } \\
\text { [...]“" }\end{array}$ & $?$ & \\
\hline $\mathrm{D} / 6 / 3$ & $\begin{array}{l}\text { „Das ist etwas, dass wir brasilianer } \\
\text { auch machen." }\end{array}$ & $?$ & \\
\hline
\end{tabular}

Uma observação da tabela acima denota a prevalência de erros cuja classificação entre intra e interlinguais se faz dificultada por uma série de fatores atrelados ao processo de ensino-aprendizagem e que promanam da dubiedade interpretativa provocada pela própria natureza dessas construções, que resguardam semelhanças com propriedades da LM e da língua-alvo desse processo.

No caso dos erros de posição verbal (B/3/2, D/1/a e D/1/b, além das aglomerações que não conformam orações relativas, a saber, C/1/a e C/1/b), como afirmado anteriormente, pode-se tratar tanto de uma influência advinda da ordem das palavras na frase portuguesa quanto da ordem de palavras na frase declarativa alemã, e de instabilidades na interlíngua dos aprendizes que atravessam o continuum de aquisição de tipos de frases e ordens de palavras no alemão, o que se observa inclusive 
pelo fato dos mesmos informantes terem construído tanto orações relativas com verbo no final quanto orações com verbo em posição 2 (V2). Essa instabilidade também se associa ao segundo dos três $U$-shaped patterns (GASS; SELINKER, 2008), a saber, a desestruturação da interlíngua do aprendiz, ao qual são feitas referências mais detidamente no subcapítulo 1.2.3.1 deste trabalho.

Os erros relativos à forma assumida pelo pronome relativo, ou, em otras palavras, à sua declinação, também remetem, em vários casos, tanto a condições próprias da LM quanto à instabilidade da interlíngua do aprendiz e à interferência gerada por outras formas e conhecimentos próprios da LE. Primeiramente, e no tocante à possível influência da LM nesses erros, é preciso considerar-se o fato de que todas as 16 formas assumidas pelos pronomes relativos alemães ${ }^{205}$ podem ser traduzidas em português como "que". Um trabalho seminal acerca das orações relativas do português brasileiro é o de Fernando Tarallo (1983 ${ }^{206}$, apud KENEDY, 2009, p. 30-31) ${ }^{207}$. Kenedy (op. cit.) aponta

o fato de, nos dados analisados por Tarallo, relativas pied-piping (a estratégia padrão para as relativas preposicionadas), como em (1a), serem praticamente inexistentes em $\mathrm{PB}$, mas de alta produtividade em $\mathrm{PE}$, bem como para a farta ocorrência de relativas resumptivas e cortadoras, como em, respectivamente, (1b) e (1c), nos dados do $\mathrm{PB}$, por contraste à sua baixa produtividade ou inexistência em PE.

1) a. A pessoa com quem eu conversei ficou doente.

b. A pessoa que eu conversei com ela ficou doente.

c. A pessoa que eu conversei ficou doente.

\footnotetext{
205 Nessa conta se inclui o genitivo, não integrado a esta pesquisa, mas que em português brasileiro oralizado surge em formas como "o homem que a mulher dele veio aqui".

206 TARALlO, F. Relativization strategies in Brazilian Portuguese. Tese de doutorado. Philadelphia: University of Pennsylvania, 1983.

${ }^{207}$ O trabalho de Tarallo acerca das orações relativas no português foi baseado em uma comparação entre ocorrências desse tipo de orações nas variantes brasileira e europeia da língua, com base em análise de corpora, tendo desenvolvido sua célebre hipótese paramética que, se por um lado influenciou diversos linguistas que vieram a conduzir trabalhos aplicados a outros fenômenos linguísticos tendo essa teoria como base, também gerou críticas e teve seus postulados e metodologia postos em cheque. Para uma visão geral dessa questão, recomenda-se a leitura do artigo de Kenedy (2009). Não faz parte do escopo da presente dissertação discutir em profundidade as propostas de Tarallo, mas sim mencionar suas importantes observações acerca da realização das orações relativas no português brasileiro, sobretudo coloquial, e o uso generalizado do "que". Os méritos da comparação Brasil/Portugal (PB - português brasileiro, e PE - português europeu) tampouco são de interesse nesta ocasião.
} 
A grande ocorrência do uso do "que" em orações relativas construídas por falantes de português brasileiro e a queda da preposição, como se observa no exemplo $c$ retomado por Kenedy, poderia explicar os seguintes erros encontrados no corpus:

(*) „Das ist der Mann, den ich ein Kind habe“(B/1/1) - literalmente, "este é o homem que eu tenho um filho")

(*) „Das ist der Mann, den ich mich nicht erinnern kann“ (B/4/1) - literalmente, “este é o homem que eu não posso/consigo me lembrar")

(*),, Margarinien ist ein kleines Land, das Antek Pistole wohnte." (B/3/5) literalmente, "Margarínia é um pequeno país que Antek Pistole morava".

No caso dos dois últimos exemplos, poderíamos falar em extensão por analogia, dando-se o uso de um vocábulo porque ele compartilha traços sintáticos com um da LM ("das"/"que"). Ao mesmo tempo, hão-se de considerar dois importantes fatores. Primeiramente, não é possível afirmar com certeza tratar-se, nestes exemplos, de uma indiscutível influência do português. Não se sabe se os autores dessas frases acreditam, no bojo de seus conhecimentos em construção acerca da gramática alemã, que o verbo alemão "sich erinnern" (lembrar-se) seja transitivo direto e que a expressão "der Mann, den ich ein Kind habe" consista naquela que se usa no alemão corrente. Além disso, é importante levar em conta certas limitações da pesquisa de Tarallo apontadas por Kenedy (2009, p. 33-34):

$\mathrm{O}$ autor analisou um corpus de língua falada bastante heterogêneo, que continha falantes cultos e falantes com média e baixa escolarização, incluindo trabalhadores da classe operária do estado de São Paulo e também tipos de fala muito díspares, como a conversa casual e a dissertação livre.

Essa consideração nos faz questionar - embora não possamos desconsiderá-la totalmente - a hipótese de que as orações relativas construídas pelos informantes desta pesquisa tenham como motivação a inteferência de formulações comuns no português brasileiro como "a pessoa que eu conversei ficou doente". Com base em minha intuição linguística de falante nativo de $\mathrm{PB}$, posso afirmar ser essa uma construção presente na linguagem oral própria de diversos socioletos brasileiros, incluindo-se, aqui, falares informais e coloquiais de pessoas de escolaridade mais alta. Apesar disso, não se pode desconsiderar o fato de que os informantes dos dois grupos possuem em média alta 
escolaridade, sendo todos universitários, graduados ou pós-graduados. Nesses casos, o conhecimento da norma culta aplicável na elaboração de textos escritos e de orações relativas preposicionadas fez parte de seus currículos escolares e seu domínio era esperado em seu desempenho nos exames vestibulares aos quais se submeteram. Não será possível retornar aos informantes e proceder a uma coleta extensiva de sua produção linguística oral e escrita com vistas à realização de uma análise de seus idioletos. Entretanto compete-nos considerar os dados acerca de sua escolaridade e condições socioeconômicas que nos foram fornecidos pelos professores e questionar, portanto, uma interpretação supostamente inequívoca dos dados e das raízes dos erros registrados. Por esse motivo, uma das funções deste trabalho e da análise que se realizou é levantar perguntas, indicar algumas possibilidades de respostas que se vislumbram e sublinhar, assim, o caráter multifacetado e multifatorial dos dados coletados, os quais muitas vezes não abrem espaço para uma análise sumamente objetiva e que aponte para soluções claramente delineadas.

No tocante aos demais exemplos de erros concernentes ao pronome relativo, sua forma e declinação, deparamo-nos com uma situação em que, como já se afirmou anteriormente, todas as formas dos relativos alemães podem ser substituídas em português por "que", o que poderia minimizar, junto aos aprendizes e suas interlínguas em construção, a noção da relevância do emprego das formas adequadas nas situações que as exigem. Além disso, a declinação incorreta do pronome relativo, ainda que cause irritação junto ao receptor da mensagem, não costuma afetar a compreeensibilidade do discurso. Trata-se, neste caso, de erros que, no geral, pouco afetam a comunicação. Sobre esse tipo de erros, comenta Figueiredo, F. (2004, p. 96):

\footnotetext{
podemos concluir que os falantes nativos, às vezes, são incapazes de entender os erros de um aprendiz. Nesses casos, não ocorre comunicação. Esses erros são os menos aceitáveis e os que devem receber uma atenção especial por parte tanto do aprendiz como do professor de segunda língua. Ao mesmo tempo, aqueles erros que são entendidos e considerados aceitáveis pelos falantes nativos podem, temporalmente, ser ignorados.
}

Este trecho lança luz na questão essencial da análise e consideração do fator compreensibilidade quando tratamos os erros dos aprendizes. Nele, o autor menciona o falante nativo como juiz ideal da compreensibilidade da linguagem produzida pelos alunos, mas se sabe que nem todo falante nativo produz linguagem adequada à norma 
culta e, no caso do presente trabalho, em que, além da compreensibilidade, considera-se a gramaticalidade das sentenças construídas, não se pode partir do pressuposto de que o falante nativo será sempre capaz de proceder a esse segundo julgamento (erro ou acerto gramatical). Também é importante considerar as diferenças entre aquilo que compreendem nativos pouco acostumados à interlíngua de um aprendiz específico e aqueles que já conhecem as características do repertório linguístico de um dado indivíduo, bem como a diferença entre aquilo que compreende um professor que está acompanhando as etapas da construção da interlíngua dos aprendentes e alguém de fora desse contexto. Por fim, devem-se considerar distinções entre o que entende um falante nativo de uma língua e o que entende um falante não-nativo que também a estudou formalmente, e a intensidade de contato e familiaridade que tenha um determinado nativo com falares e interlínguas de estrangeiros. Apesar de todas essas considerações, observa-se, nos exemplos listados na tabela, que as orações construídas pelos informantes e que contém erros de declinação do pronome relativo mantêm-se compreensíveis para nativos e não-nativos que dominem o alemão, com diferentes níveis de irritação/esforço que variam de interlocutor para interlocutor e de acordo com diferentes contextos e situações. Ilustram essa informação os seguintes exemplos:

(*),, Das ist der Mann, den ein großes Auto hat"(B/3/1) - "este é o homem que tem um carro grande“, com pronome relativo no acusativo em vez de no nominativo, forma adequada para esta situação, uma vez que o relativo ocupa, nesta oração, a posição de sujeito.

(*),, Wir haben drei Kinder, denen an der Porto Seguro Schule besuchen." $(B / 4 / 3)$ - literalmente, "nós temos três filhos/crianças que frequentam na escola Porto Seguro" - o pronome relativo "denen” (dativo plural) ocupa a posição de sujeito, reservada para os nominativos.

Como já foi comentado, na produção mais livre (atividades C e D), onde havia liberdade para a formulação de qualquer tipo de oração relativa, os alunos elaboraram uma maioria de orações relativas no nominativo. Aqui se retorna, portanto a uma questão prenunciada algumas páginas atrás. Uma incidência maior de orações relativas no acusativo e no dativo surgiu na atividade $\mathrm{B}$, na qual a indicação a priori de pronomes relativos ou verbos que deveriam fazer parte da oração a ser elaborada pelo informante induzia, ou deveria induzir, a construção de orações em casos outros que não o 
nominativo. Apesar disso, chama atenção um fenômeno que aconteceu junto a vários informantes no momento de completar a oração „Ich rede immer mit meiner Ärztin, der..." (frase 2 da atividade B). A indicação do pronome relativo "der", um feminino no dativo, em relação com o correlato "meiner Ärztin", implica a necessidade de que se empregue um verbo que exija dativo, como na frase formulada pela informante 2, "Ich rede immer mit meiner Ärztin, der ich alles erzählen kann" ("eu converso sempre com minha médica, a quem eu posso contar tudo"). Entretanto, 9 informantes elaboraram frases nas quais o pronome relativo "der" funcionava como sujeito. Embora as frases sejam compreensíveis, é notório o fato de que o pronome relativo "der", quando no nominativo, pertence ao gênero masculino, não podendo, desse modo, em uma frase que se pretenda gramatical, fazer referência ao correlato feminino presente na oração principal. As orações formuladas foram:

(*),, Ich rede immer mit meiner Ärztin, der ist die besten in mein land. “ (B/3/2)

(*),, Ich rede immer mit meiner Ärztin, der immer um mich gekummert hat." $(\mathrm{B} / 4 / 2)$

(*),, Ich rede immer mit meiner Ärztin, der mein Nachbar auch ist. “ (B/5/2)

(*),, Ich rede immer mit meiner Ärztin, der eine sehr interessante Frau ist.“ $(\mathrm{B} / 6 / 2)$

Nesses exemplos, pode-se supor que tenha havido uma influência da tradução universal "que", aplicável a todos os relativos, consistindo, assim, num caso de erros interlinguais, mas também é possível interpretar esses erros como sendo intralinguais, pertencentes à categoria "formas alternadas de membros da mesma classe" ou “confusão entre termos lexicais semelhantes". Chama a atenção o uso forçoso do nominativo inclusive em um contexto gramatical que exigia outro caso.

Localiza-se, ainda, um erro de natureza intralingual, pertecente à categoria “ordem indevida de palavras”. Trata-se da frase „In der Sprachenschule, der bei wir lernen, heißt ****“. Nela, chama a atenção a inversão da ordem canônica preposição + pronome relativo, que é também a ordem canônica das relativas preposicionadas em português. Portanto não existem evidências, neste caso, de influência da LM, de modo que, aqui, nos deparamos com um erro intralingual único. Este é o único erro na tabela ao qual não parece arrazoado atribuir a possibilidade de interferência da LM. 
Uma das funções de uma tabela, em um trabalho desta natureza, é a de facilitar a visualização dos dados, de modo a concentrar a atenção do leitor em determinados aspectos da informação que se lhe apresenta. No caso desta tabela, a predominância do ponto de interrogação nos campos dedicados à classificação dos erros e das células vazias na coluna "subtipo" denota a dificuldade inerente à análise desses erros em classificá-los definitivamente entre uma e outra categoria. Isso aponta para as vicissitudes das orações relativas e de seu processo de aprendizagem por parte de aprendizes brasileiros. Faz-se essencial considerar, como já asseverado, tanto a influência da tradução "que", aplicável a todos os 16 pronomes relativos alemães (influência da LM), o que dissiparia, para muitos informantes, a real distinção gramatical entre eles, bem como a dificuldade de assimilação das diferenças entre essas variantes do pronome relativo em função de gênero, número e caso, o que pode levar o aluno a alternar formas, empregando um pronome no acusativo em um lugar reservado a um nominativo ou dativo, bem como cometendo erros de concordância de gênero e número com o correlato etc. $\mathrm{O}$ fato de as orações permanecerem compreensíveis a despeito do uso equivocado dos pronomes relativos também corrobora por uma menor exatidão de seu emprego por parte dos aprendentes. Além disso, convém lembrar que as formas dos pronomes relativos no nominativo, acusativo e dativo foram apresentadas de uma só vez aos alunos, correspondendo à abordagem analítica de progressão de tópicos gramaticais em cursos de LE, de modo a exigir mais da memória de trabalho, que pode ser sobrecarregada devido ao grande volume de informações a serem processadas e mobilizadas. 


\subsection{2 $2^{\circ}$ grupo de informantes (B): studio $d$ (6 informantes), em comparação com o Grupo A}

\subsubsection{Atividade A}

$\mathrm{Na}$ atividade $\mathrm{A}$, todos os alunos do grupo B montaram frases corretas de acordo com o (con)texto que lhes foi apresentado, e também de acordo com as regras de funcionamento da estrutura gramatical ensinada. Uma vez que os resultados desta atividade foram idênticos aos do grupo $\mathrm{A}^{208}$, eles não serão reapresentados nesta parte do trabalho. Sugere-se, assim, a verificação da descrição dos resultados da atividade A no início do presente capítulo.

Uma observação que deve ser feita, neste momento, é que o sucesso dos informantes dos dois grupos ao realizarem a atividade A demonstra a maior facilidade dos aprendizes em resolver exercícios sumamente reprodutivos e nos quais se espera a identificação de estruturas e sentidos, e não sua produção, exigindo menos de sua memória e com a contextualização auxiliando nas respostas, cuja dificuldade não se concentra apenas na questão gramatical e na identificação da relação correlato/relativo, mas sim em uma reconstrução de sentidos explicitados no texto previamente lido.

\subsubsection{Atividade B}

$\mathrm{Na}$ atividade $\mathrm{B}$, ao focarmos a questão posição verbal, observaremos que apenas dois informantes ( 1 e 5) construíram, cada um, uma oração com verbo na posição 2 , em vez de ao final da oração relativa, de um total de 5 orações construídas; ou seja, cada um desses dois alunos, ao cometerem apenas um erro dessa natureza no conjunto do exercício, acertou $80 \%$ das frases no tocante a este quesito. Os demais informantes situaram todos os verbos ao final das frases. A partir desta observação, pode-se afirmar a) que a assimilação do elemento "posição verbal" no contexto de aprendizagem das

\footnotetext{
${ }^{208}$ Neste grupo, não se deram as exceções (aceitas como corretas) que se registraram junto ao grupo A.
} 
vicissitudes morfosintáxicas das orações relativas foi bem assimilado por esse grupo, e b) que o fato de dois aprendizes terem cometido cada um um erro no tocante a essa questão, em um contexto maior de 4 acertos em um total de 5 frases, reafirma a instabilidade da interlíngua em construção dos alunos e as remissões esporádicas a erros que podem afetar elementos da gramática da língua-alvo aparentemente aprendidos e assentados. Como em outros momentos desta análise, não será possível, entretanto, afirmar categoricamente quais seriam as motivações desses erros isolados. Provavelmente se trata de enganos, e não de erros propriamente ditos, devido ao fato dos aprendizes terem demonstrado, no restante das orações construídas, a aplicação do conhecimento da regra gramatical aqui discutida. Repete-se, assim, o resultado registrado na análise dos dados do Grupo A (2 erros).

No tocante à questão do pronome relativo, sua concordância com o correlato na oração principal e sua flexão adequada, observaram-se, como esperado, mais desvios com relação ao modelo linguístico apresentado aos alunos. Vejam-se as ocorrências, transcritas na sequência:

\section{Informante 1:}

(*) 1. Das ist der Mann, den suche ich.

- Das ist der Mann, den ich suche.

[Este é o homem que eu procuro/estou procurando.]

(*) 2. Ich rede immer mit meiner Ärztin, der mir hilft.

- Ich rede immer mit meiner Ärztin, die mir hilft.

[Eu converso sempre com minha médica que me ajuda.]

3. Wir haben drei Kinder, die in Margariene studiert.

- Wir haben drei Kinder, die in Margarinien studieren.

[Nós temos três filhos que estudam/fazem faculdade em Margarínia.]

4. não foi feita.

(*) 5. Margarinien ist ein kleines Land, das ich wohne.

- Margarinien ist ein kleines Land, in dem ich wohne.

[Margarínia é um pequeno país no qual eu moro.] 


\section{Informante 2:}

1. Das ist der Mann, den ich letzte Montag fotografiert.

- Das ist der Mann, den ich letzten Montag fotografiert habelfotografierte. [Este é o homem que eu fotografei na última segunda-feira.]

2. Ich rede immer mit meiner Ärztin, der ich gratuliert habe.

[Eu converso sempre com minha médica que eu cumprimentei.]

3. Wir haben drei Kinder, die in Schule sind.

- Wir haben drei Kinder, die in der Schule sind.

[Nós temos três filhos/crianças que estão na escola.]

4. não foi feita.

5. Margarinien ist ein kleines Land, in dem Pistole wohnte. [Margarínia é um pequeno país no qual Pistole morava.]

\section{Informante 3:}

1. Das ist der Mann, den ich nicht kenne.

[Este é o homem que eu não conheço.]

(*) 2. Ich rede immer mit meiner Ärztin, der ich seit.

- oração incompleta

3. Wir haben drei Kinder, mit denen wir leben.

[Nós temos três crianças/fillhos com os quais nós vivemos.]

4. In der Sprachenschule, in der wir lernen, machen wir viel Spaß̧.

[Na escola de línguas na qual estudamos nós fazemos muitas piadas.]

(*) 5. Margarinien ist ein kleines Land, das meine Tante wohnte.

- Margarinien ist ein kleines Land, in dem meine Tante wohnte.

[Margarínia é um pequeno país no qual minha tia vivia/viveu.]

\section{Informante 4:}

1. Das ist der Mann, den ich gesehen habe. 
[Este é o homem que eu vi.]

2. Ich rede immer mit meiner Ärztin, der ich gratuliert habe.

[Eu converso sempre com minha médica que eu cumprimentei.]

3. Wir haben drei Kinder, die sehr traurig sind.

[Nós temos três crianças/filhos que são/estão muito tristes.]

4. In der Sprachenschule, in der wir lernen, gibt es viele Leute.

[Na escola de idiomas na qual estudamos há muita gente.]

5. Margarinien ist ein kleines Land, in dem ich wohnte.

[Margarínia é um pequeno país no qual eu morei/morava.]

\section{Informante 5:}

(*) 1. Das ist der Mann, den Ich mag nicht.

- Das ist der Mann, den ich nicht mag.

[Este é o homem de quem eu não gosto.]

(*) 2. Ich rede immer mit meiner Ärztin, der Kopfschmerzen ich habe.

- $\quad$ aglomeração

3. Wir haben drei Kinder, die in die schule gehen.

- Wir haben drei Kinder, die in die Schule gehen.

[Nós temos três filhos/crianças que vão à escola.]

4. não foi feita

(*) 5. Margarinien ist ein kleines Land, das Antek wohnte.

- Margarinien ist ein kleines Land, in dem Antek wohnte. [Margarínia é um pequeno país no qual Antek morava.]

\section{Informante 6:}

(*) 1. Das ist der Mann, den Deutschkurz lernt.

- Das ist der Mann, der den/einen Deutschkurs besucht.

[Este é o homem que frequenta o/um curso de alemão.] 
(*) 2. Ich rede immer mit meiner Ärztin, der meinen Freund liebt.

- Ich rede immer mit meiner Ärztin, die meinen Freund liebt.

[Eu converso sempre com minha médica que ama meu amigo/namorado.]

(*) 3. Wir haben drei Kinder, denen in Schule studieren.

- Wir haben drei Kinder, die an/in der Schule lernen.

[Nós temos três crianças/filhos que estudam na escola.]

(*) 4. In der Sprachenschule, $\underline{\text { mit }} \underline{\text { den }}$ wir lernen, $\underline{\text { ist größer. }}$

- aglomeração

(*) 5. Margarinien ist ein kleines Land, den Antek Pistole wohnte.

- Margarinien ist ein kleines Land, in dem Antek Pistole wohnte.

[Margarínia é um pequeno país no qual Antek Pistole morava.]

Nas ocorrências acima transcritas, observa-se que alguns dos erros cometidos pelos informantes incidiram sobre frases que também se mostraram problemáticas para aprendizes do primeiro grupo. No caso da frase 2 a ser completada, "Ich rede immer mit meiner Ärztin, der... “, que exige o emprego de um verbo, locução ou colocação que exija dativo, registram-se como corretas a formulação dos informantes 2 e 4 ("Ich rede immer mit meiner Ärztin, der ich gratuliert habe”), que empregaram o verbo "gratulieren" (cumprimentar, com dativo). Um informante não concluiu a frase (3). Dois informantes (1 e 6), à semelhança do que ocorreu no grupo A, construíram frases em que o pronome relativo "der" funciona no lugar de um nominativo feminino, embora apenas possa corresponder, em frases gramaticalmente corretas de acordo com o modelo linguístico apresentado aos informantes, ao nominativo masculino ou dativo feminino. Um informante (5) introduziu o sujeito "ich" (eu) na frase, o que resultou numa construção cujo sentido é de difícil apreensão, embora se identifique o elemento "Kopfschmerzen habe" (tenho dor de cabeça), semanticamente pertencente ao contexto da oração principal, que inclui o correlato "Ärztin" (médica): "Ich rede immer mit meiner Ärztin, der Kopfschmerzen ich habe" ("eu converso sempre com minha médica, a qual [?]/que eu tenho dor de cabeça"). O erro do informante 1 aponta para uma questão intralingual, de transferência mal ambientada de conhecimento gramatical. $\mathrm{O}$ verbo "helfen" (ajudar) é um dos primeiros que se ensina, nos LDs de ALE empregados nos cursos em que se deu a coleta de dados, como exigindo dativo. Aparentemente, o aluno identificou no pronome relativo "der" o dativo, utilizando, assim, o verbo 
"helfen" na oração que construiu, porém não empregou o relativo como objeto da oração e sim como sujeito, o que consistiu em erro.

Outra frase desse exercício junto à qual os informantes apresentaram maiores dificuldades é a de número 5 (“Margarinien ist ein kleines Land, ...”). Todos os alunos procuraram formular frases em que se expressaria que "Margarínia é um pequeno país no qual" alguém morava (em dois casos, o sujeito foi "ich", em três casos o personagem do texto, Antek Pistole, e em um caso "meine Tante" - minha tia). Dois alunos (2 e 4) introduziram corretamente a preposição "in" e o pronome relativo neutro no dativo, "dem". Três alunos, porém, empregaram o pronome relativo "das" (neutro nominativo ou acusativo), tendo incidido, assim, em erro de flexão de caso do pronome. Essa dificuldade, como se observa, reside na necessidade de declinação do pronome no caso dativo, reafirmando a ponderação anterior de que a construção de frases e contextos em que surjam (ou precisem surgir) palavras declinadas em casos outros que não o nominativo oferece um desafio maior aos estudantes brasileiros de ALE. Porém chama a atenção o fato de que todos os informantes, à execeção da de número 6 , empregaram corretamente verbos que exigem o acusativo na oração 1 (“Das ist der Mann, den...”), na qual foi previamente informado o pronome relativo masculino dativo, “den". A informante 6, por sua vez, formulou erroneamente todas as orações, no tocante à gramaticalidade do pronome relativo, demonstrando haver feito um uso aleatório desses elementos nas frases, o que indica um problema maior e geral de assimilação dessa estrutura por sua parte, de forma excepcional dentro do grupo. De um total de 27 orações relativas formuladas pelo grupo nesta atividade, um total de 16 (56\%) não apresenta problemas associados à forma do pronome relativo, tendo havido, como recém se afirmou, alguma desigualdade entre as produções dos diversos informantes, com a aprendiz 6 tendo errado todas as frases e o informante 4 tendo formulado todas as frases de forma correta no tocante ao pronome relativo. $\mathrm{O}$ informante 2 formulou um total de 4 frases, todas corretas, mas não formulou a oração 4, que induzia o uso de preposição e dativo. $\mathrm{O}$ fato de 3 informantes não terem completado a oração 4 se deve à sua maior dificuldade, uma vez que, dado o número de espaços oferecidos, esperava-se a elaboração de uma relativa preposicionada. 
$\mathrm{Na}$ atividade $\mathrm{C}$, não foram informados os pronomes nos fragmentos indicados para que o aluno os completasse com uma relativa, de modo a exigir, assim, um maior nível de produção por parte dos informantes. Vejam-se, pois, os resultados.

\subsubsection{Atividade $\mathrm{C}$}

\section{Informante 1:}

(*) a. Die Geschichte von Antek Pistole ist der Roman, den Besen macht.

- aglomeração

(*) b. Zwischen Europa und Asien liegt die Türkei, das ein klein Land ist.

- Zwischen Europa und Asien liegt die Türkei, die ein kleines Land ist. [Entre Europa e Ásia fica a Turquia, que é um país pequeno.]

\section{Informante 2:}

(*) a. Die Geschichte von Antek Pistole ist der Roman, der ein Besenbender war.

- aglomeração

b. Zwischen Europa und Asien liegt die Türkei, die großer als Margarinien ist. Zwischen Europa und Asien liegt die Türkei, die größer als Margarinien ist. [Entre Europa e Ásia fica a Turquia, que é menor que Margarínia.]

\section{Informante 3:}

(*) a. Die Geschichte von Antek Pistole ist der Roman, der Besen macht.

- aglomeração

b. Zwischen Europa und Asien liegt die Türkei, die sehr chaotische ist. Zwischen Europa und Asien liegt die Türkei, die sehr chaotisch ist. [Entre Europa e Ásia fica a Turquia, que é muito caótica.] 


\section{Informante 4:}

a. Die Geschichte von Antek Pistole ist der Roman, der aus Margarinien ist. [A história de Antek Pistole é o romance que é de Margarínia.]

b. Zwischen Europa und Asien liegt die Türkei, die sehr schön ist. [Entre Europa e Ásia fica a Turquia, que é muito bonita.]

\section{Informante 5:}

(*) a. Die Geschichte von Antek Pistole ist der Roman, der Besen macht.

- aglomeração ("a história de Antek Pistole é o romance que faz vassouras").

b. Zwischen Europa und Asien liegt die Türkei, die kleines land ist.

- Zwischen Europa und Asien liegt die Türkei, die ein kleines Land ist. [Entre Europa e Ásia fica a Turquia, que é um país pequeno.]

\section{Informante 6:}

(*) a. Die Geschichte von Antek Pistole ist der Roman, den aus Margarinien ist.

- Die Geschichte von Antek Pistole ist der Roman, der aus Margarinien ist. [A história de Antek Pistole é o romance que é de Margarínia.]

(*) b. Zwischen Europa und Asien liegt die Türkei, dem in Süden ist.

- Zwischen Europa und Asien liegt die Türkei, die im Süden ist. [Entre Europa e Ásia fica a Turquia, que está no sul.]

Nesta atividade, todos os alunos formularam orações relativas com o verbo situado ao final, ou seja, não se registraram erros de posição verbal, confirmando-se, assim, a hipótese inspirada pela análise dos dados de que a assimilação desse aspecto da gramaticalidade das orações relativas se dá de maneira mais fácil e fluída que a das diversas formas e funções assumidas pelo pronome relativo que as introduz (ou que segue a preposição que o faz). Isso se nota a despeito da dificuldade inerente à aquisição-aprendizagem dessa estrutura e das instabilidades visíveis nos registros da interlíngua de alguns aprendizes, assim como verificado no seu desempenho na atividade $\mathrm{B}$. 
Quando observamos a performance dos alunos ao completar a frase $a$, percebemos que 4 deles formularam orações semanticamente inviáveis, devido, provavelmente, a uma interpretação errônea do significado do correlato "Roman", algo que também se verificou na produção dos informantes do primeiro grupo analisado. "Roman", nas possíveis perspectivas de um receptor brasileiro, é potencialmente tanto um cognato ("romance", significado do lexema em português) quanto um falso cognato ("romano"). Devido a esse fato, como já se observou durante a análise dos dados do grupo anterior, foi solicitado aos professores voluntários que explicitassem, no momento de distribuir as atividades para os alunos, o real significado dessa palavra, algo que eles confirmam ter feito. Apesar disso, não é possível controlar onde estava depositada a atenção dos alunos no momento dessa notificação, e erros foram registrados provavelmente devido à falta de compreensão do sentido desse correlato. Dessas 4 orações, se considerarmos a possibilidade de que os informantes estejam se referindo a um romano, obteremos 3 orações sintaticamente corretas, i.e., nas quais se observa concordância correlato/relativo e flexão adequada do relativo:

"Die Geschichte von Antek Pistole ist der Roman, der ein Besenbender war". (Inf. 2)

"Die Geschichte von Antek Pistole ist der Roman, der Besen macht". (Inf. 3 e 5)

Soma-se a essas três orações uma incorreta, elaborada pelo informante 1, que empregou o pronome relativo masculino no acusativo em função de sujeito (“... der Roman, den Besen macht" - negrito meu).

As outras formulações relativas à frase $a$ foram:

"Die Geschichte von Antek Pistole ist der Roman, der aus Margarinien ist". (Inf. 4)

"Die Geschichte von Antek Pistole ist der Roman, den aus Margarinien ist". (Inf. 6)

A oração construída pelo informante 4 se mostra adequada semântica e morfossintaticamente, enquanto que o informante 6 , à semelhança do informante 1 , 
empregou "den" (pronome relativo masculino no acusativo) em função de sujeito, função essa reservada para o nominativo "der".

Na segunda oração a ser completada (b: "Zwischen Europa und Asien liegt die Türkei, ...”), 4 dos 6 informantes (2, 3, 4 e 5) elaboraram orações relativas corretas no nominativo, tendo empregado o pronome relativo adequado (“die", nominativo feminino, em relação ao correlato "die Türkei”). Um informante (1) utilizou-se do pronome "das", neutro nominativo (ou acusativo), de forma a não se dar a concordância com o correlato feminino ${ }^{209}$, e outro, o de número 6, utilizou como sujeito o pronome "dem", masculino ou neutro dativo, repetindo-se, aqui, a aparente aleatoriedade dos pronomes relativos empregados por esse aprendiz, resultando em uma falta generalizada de concordância gramatical com o correlato e de adequação casual dentro do contexto da oração relativa formulada. Assim, tem-se que, de 12 orações construídas, 8 delas estão corretas, caso se considerem aceitáveis aquelas em que houve uma interpretação errônea do significado do correlato da oração a, "der Roman", ou seja, 66\%. Se se excluem essas ocorrências, de modo a considerar corretas apenas orações semanticamente viáveis, obtém-se um total de 6 , ou a metade. Nessas orações em que houve a confusão do sentido de "der Roman", podem-se registrar problemas de compreensibilidade, principalmente sob a perspectiva de um receptor nativo. No caso de professores brasileiros de ALE, ou mesmo de professores alemães nativos que atuam profissionalmente no Brasil e conhecem as características básicas da interlíngua de seus alunos brasileiros, a compreensão da raiz desse erro vê-se facilitada, o que não diminui, entretanto, o problema de compreensibilidade registrado nessas formulações. As demais são todas compreensíveis, devido ao fato de que, de forma geral, o nativo entende a oração relativa devido ao seu agrupamento geral de elementos linguísticos, mesmo quando o pronome empregado não corresponda à forma gramaticalmente correta de acordo com o registro (Hochdeutsch) apresentado aos alunos.

\footnotetext{
${ }^{209}$ É possível que esse erro tenha sido ocasionado por influência do gênero do predicativo ("ein klein Land" [sic], em alemão-padrão "ein kleines Land".
} 


\subsubsection{Atividade D}

$\mathrm{Na}$ atividade $\mathrm{D}$, de um total de 26 orações relativas livremente formuladas pelos informantes, registrou-se apenas um erro de posição verbal, mais precisamente a oração 2 do informante 2, "Die Bohnen, denen schmeckt mir schlecht, waren kalt!", que formulou outras 4 com o verbo corretamente situado. Repete-se, assim, o que se observou nas atividades $\mathrm{B}$ e $\mathrm{C}$ e tem-se, aqui, a probabilidade de um engano. Os erros associados ao pronome relativo foram mais numerosos e serão analisados, a seguir, aluno por aluno, devido ao caráter mais diverso e complexo dessas produções livres.

Informante 1: O aluno escreveu um texto sobre a irmã que vive na Suíça e trabalha numa loja de chocolates.

1. Das ist Carolina, die meine Schwester ist. [Esta é Carolina, que é minha irmã.]

2. Sie habe ein Son, der 4 Jahre alt ist.

- Sie hat einen Sohn, der 4 Jahre alt ist. [Ela tem um filho que tem 4 anos de idade.]

(*) 3. Sie wohnen in der Schweiss, den die besser Schokolade produziert.

- Sie wohnen in der Schweiz, die die beste Schokolade produziert. [Eles moram na Suíça, que produz o melhor chocolate.]

4. Die Schokolade, die ein Deutsch erfindet, mein lieblings essen ist.

- Die Schokolade, die ein Deutscher erfunden hat, ist mein Lieblingsessen. [O chocolate, que um alemão inventou, é meu alimento preferido.]

(*) 5. Carolina arbeitet in eine Schokolade Geschäft, die auch meine Tante arbeitet.

- Carolina arbeitet in einem Schokoladengeschäft, in dem meine Tante auch arbeitet.

[Carolina trabalha numa loja de chocolates na qual minha tia também trabalha.]

Um dos erros relacionados com o pronome relativo cometidos por esse informante parece ter como raiz um problema na identificação gramatical do correlato. Primeiramente, observam-se os três acertos: na frase $a$, a relação adequada entre o 
correlato "Carolina" e o relativo "die"; na frase b, entre "ein Son" ["einen Sohn"] e o relativo "der"; e a correspondência, na frase 4, entre "die Schokolade" e "die". Por sua vez, na frase 5 observa-se que ao correlato "(in) einem Schokoladengeschäft", neutro, grafado pelo informante como "in eine Schokolade Geschäft", associou-se o relativo "die" (feminino, assim como a indicação do correlato pelo aprendiz). "Eine"210, assim como escrito pelo aprendente, é uma forma feminina, de modo que, aqui, deu-se um caso de concordância entre o gênero que o autor da frase parece crer que o correlato tenha e o pronome por ele indicado na oração relativa, à semelhança do que fez o informante 1 do Grupo A (atividade D) na concordância "ein Sache"/"das" (o correto seria "eine Sache"/"die").

Na frase 3, observa-se o correlato “(in) der Schweiz” (“(n)a Suíça”, adjunto adverbial de lugar no dativo), e o relativo "den" (masculino acusativo) na função de sujeito, em um caso de alternância e não diferenciação de formas gramaticais na língua estrangeira. Assim, das 5 orações formuladas pelo informante, 3 não apresentam erros primários; no caso de uma, existe concordância gramatical entre correlato e relativo, porém com troca do gênero do correlato por parte do aprendiz, e uma incidência de erro primário absoluto, em completa discordância correlato/relativo e um acusativo em lugar de sujeito.

Informante 2: O informante escreveu sobre uma ida ao restaurante com a mãe.

1. Gestern habe ich mit meiner Mutter im Restaurant, das nicht gut war, getroffen.

- Gestern habe ich mich mit meiner Mutter in einem Restaurant, das nicht gut war, getroffen.

[Ontem encontrei minha mãe num restaurante que não era bom.]

(*) 2. Die Bohnen, denen schmeckt mir schlecht, waren kalt!

- Die Bohnen, die mir schlecht schmeckten, waren kalt! [Os feijões, que estavam ruins, estavam frios.]

3. Die Kellnerin, die die Teller schon vergessen hat, hat auch unsere Rechnung vergessen.

- Die Kellnerin, die die Teller schon vergessen hatte, hat auch unsere Rechnung vergessen.

\footnotetext{
${ }^{210}$ Emboa a forma gramaticalmente correta, caso o correlato fosse seminino, seria "einer", uma vez que o contexto (adjunto adverbial de lugar) exige dativo.
} 
[A garçonete, que já tinha esquecido os pratos, também esqueceu nossa conta.]

4. Wir reden immer über ein Buch, das wir im Moment lesen.

[Nós conversamos sempre sobre um livro que estamos lendo no momento.]

(*) 5. (...) und sie hat nach Hause, die nach dieses Restaurant ist.

- (...) und sie ist nach Hause gegangen, das in der Nähe von diesem Restaurant ist.

[(...) e ela foi para casa, que é perto desse restaurante.]

O informante 2 formulou 3 orações relativas corretas, duas delas com pronome relativo no nominativo e uma no acusativo. Entre seus erros (2), encontra-se um caso de falta de concordância de gênero entre correlato e pronome ("Hause"/"die"), verificandose o emprego do pronome feminino "die" em vez de "das" (neutro como o correlato Hause) e um caso de transferência indevida de conhecimento gramatical na LE ("Die Bohnen, denen schmeckt mir schlecht, waren kalt!'). Nesse caso, observa-se que o verbo da oração relativa, "schmecken", abre espaço para um complemento no dativo, assim como normalmente se ensina aos aprendizes de ALE; contudo, ele também abre espaço para um nominativo (sujeito), que, no caso, foi indicado pelo informante também no dativo, provavelmente por uma generalização da regra "schmecken + dativo". Esse pronome relativo, embora se encontre no caso inadequado, concorda em número (plural) com o correlato "Bohnen". Assim, encontram-se 2 erros de pronome relativo em 5 frases (ou 1 em 5, se se considerar a concordância "eine Schokolade Geschäft"/"die" [sic]), e o único erro de posição verbal registrado nessa atividade, considerando-se todos os 6 informantes.

Informante 3: $\mathrm{O}$ aprendiz escreveu sobre seu trabalho como engenheiro e o trabalho de sua esposa num banco.

1. Ich arbeit in einer Firma, die sehr grösse ist.

- Ich arbeite in einer Firma, die sehr groß ist.

[Eu trabalho em uma firma que é muito grande.]

2. Ich bin ein Bauingenieur, der Brücke bauet.

- Ich bin ein Bauingenieur, der Brücken baut. [Eu sou um engenheiro civil que constrói pontes.] 
3. Ich habe drei Kinder, die sehr schöne sind.

- Ich habe drei Kinder, die sehr schön sind.

[Eu tenho três crianças/filhos que são muito bonitos.]

4. Meine Frau arbeitet in einer Bank, die sehr wichtig in den USA ist.

[Minha esposa trabalha em um banco que é muito importante nos EUA.]

O informante 3 formulou 4 orações relativas sem erros primários. Todas elas, entretanto, são orações relativas simples com pronome introdutório no nominativo e a estrutura pronome relativo sujeito (nominativo)/predicativo do sujeito/verbo. No caso da oração 4, houve a inclusão de um advérbio de lugar.

Informante 4: $\mathrm{O}$ aluno escreveu um texto em primeira pessoa contando onde vive, com que trabalha, o que faz nos fins de semana e algo sobre sua família.

1. Ich wohne in São Paulo, die eine große Stadt ist.

- Ich wohne in (der Stadt) São Paulo, die eine große Stadt ist.

[Eu moro em São Paulo, que é uma cidade grande.]

2. (...) aber ich komme aus Rio de Janeiro, die schöner als São Paulo ist.

- (...) aber ich komme aus einer anderen Stadt, Rio de Janeiro, die schöner als São Paulo ist.

[(...) mas eu venho do Rio de Janeiro, que é mais bonito que São Paulo.]

(*) 3. Ich arbeit bei ein Verlag, das nur Bücher produziert.

- Ich arbeite bei einem Verlag, der nur Bücher produziert.

[Eu trabalho numa editora que produz apenas livros.]

4. Da arbeite ich gern mit meine Kollegen, die interessante sind.

- Da arbeite ich gern mit meinen Kollegen, die interessant sind.

[Eu gosto de trabalhar lá com meus colegas, que são interessantes.]

5. (...) und meine Schwester, die Lehrerin ist.

[(...) e minha irmã, que é professora.]

O informante cometeu apenas um erro primário, quando concordou o correlato "ein Verlag" [sic] com o pronome relativo "das". O substantivo "Verlag", em alemão, é masculino, devendo-lhe corresponder, em função de sujeito (nominativo), como é o 
caso da oração formulada por esse aluno, o relativo "der". Entretanto, a forma indefinida "(bei) ein Verlag" ["(bei) einem Verlag"] não deixa transparecer o gênero do substantivo, que poderia ser masculino ou neutro. Por isso, a maior probabilidade é a de que o informante tenha conscientemente empregado o relativo "das" ao crer que o correlato fosse neutro. Assim, trata-se mais de um erro de vocabulário que de um erro gramatical, ou de um erro gramatical ocasionado por problemas de vocabulário (a assimilação do substantivo com seu gênero).

Informante 5: $\mathrm{O}$ aluno escreveu brevemente sobre a esposa e o filho.

1. Ich habe ein son, der 4 jahre alt ist.

- Ich habe einen Sohn, der 4 Jahre alt ist.

[Eu tenho um filho que tem 4 anos de idade.]

2. Meine Frau ist student, die ganze tag arbeitet.

- Meine Frau ist eine Studentin, die den ganzen Tag arbeitet. [Minha esposa é uma estudante que trabalha o dia inteiro.]

3. Ich will mehr zeit mit meinem son habe, der zu viele zeit in der schule hat.

- Ich will mehr Zeit mit meinem Sohn haben, der zu viel Zeit in der Schule verbringt.

[Eu gostaria de ter mais tempo com o meu filho, que passa muito tempo na escola.]

Nas 3 frases elaboradas pelo aprendiz 5, não foram registrados erros primários.

Informante 6: $\mathrm{O}$ informante escreveu sobre seu trabalho e seus colegas.

(*) 1. Ich habe einen Job, den sehr schlecht ist.

- Ich habe einen Job, der sehr schlecht ist.

[Eu tenho um emprego que é muito ruim.]

(*) 2. Ich habe zur meinen Job gefahren, den Job in Berlin liegt.

- Ich bin zu meinem Job gefahren, der in Berlin liegt.

[Eu fui para o meu trabalho, que fica em Berlim.]

(*) 3. Ich fahre bei meinen Auto oder bei Bus, den ich über die Huberstrasse parke.

Aglomeração (? - "Eu vou com meu carro ou de ônibus, o qual eu 
estaciono sobre/na Rua Huber" - ?).

(*) 4. Meinen Kollegen haben sehr interessantes aktivitätes, denen Sie den Job lieben.

Aglomeração (? - "meus colegas têm atividades muito interessantes, as quais eles amam o emprego").

Assim como observado nas atividades anteriores, com a exceção do exercício A, o informante 6 demonstrou não ter assimilado a gramaticalidade das orações relativas. Embora a questão da posição verbal não se tenha mostrado problemática, a flexão do pronome relativo foi equivocada em todas as frases construídas ao longo de todas as atividades. Não é possível observar, nas formulações desse informante, uma sistematização de qualquer natureza no tocante ao uso dos pronomes relativos. À guisa de exemplo, na atividade D observa-se que o pronome "den" (acusativo) foi empregado ora como sujeito, ora como objeto, assim como ocorreu na atividade $\mathrm{C}$ (foi empregado como sujeito) e na atividade B (foi empregado como sujeito, mas também no lugar de um dativo). Desse modo, é possível afirmar que o informante não apenas não memorizou as formas dos pronomes relativos alemães, como também não assimilou seu uso, funções e diferenciações gramaticais.

De forma geral, entretanto, e excetuando-se o caso especial do informante 6, os alunos do grupo B cometeram menos erros na atividade $\mathrm{D}$ que os do grupo $\mathrm{A}$, sendo que uma parte relevante dos seus erros, como no caso do grupo A, foi gerada por equívocos na identificação/memorização do gênero do correlato, dando-se casos de concordância entre o gênero que incorretamente atribuíram ao correlato e o pronome relativo que indicaram para referenciá-lo, sem que a diferença entre o volume de erros de um grupo e outro se mostre especialmente significativa. Trata-se de 8 erros dentre 27 orações relativas formuladas pelos informantes do grupo B contra 12 erros entre 28 orações do grupo A, sendo que, no grupo B, 3 erros foram devidos a enganos na identificação do gênero do correlato, tendo havido concordância entre o gênero atribuído a ele pelo informante e o pronome relativo indicado, e, no grupo A, um erro foi de identificação do gênero do correlato, tendo havido concordância ("ein Sache"/"das"), um erro de identificação do correlato associado a um erro de gênero ("Die besten Platz in der Welt ist $U K$, die...") e dois casos em que o pronome "das" foi grafado "dass" (como a 
conjunção "que"). Se desconsiderados esses erros como não puramente gramaticais, tem-se um total de 8/27 no grupo A $(29,6 \%)$ e 5/26 no grupo B (19\%). Porém a diferença, da ordem de $10 \%$, não permite a tomada de conclusões definitivas quanto ao especificidades no nível de assimilação da estrutura demonstrado pelos integrantes de cada grupo.

\subsubsection{Balanço dos dados do Grupo B}

Observe-se, nas tabelas abaixo, os balanços quantitativos dos resultados obtidos junto a cada atividade:

Tabela 10 - Balanço quantitativo da atividade B, Grupo B

\begin{tabular}{|c|c|c|c|c|c|c|c|c|}
\hline atividade & informante & $\begin{array}{l}\text { total } \\
\text { frases }\end{array}$ & compreens. & $\begin{array}{l}\text { verbo } \\
\text { pos. }\end{array}$ & $\begin{array}{l}\text { pron. } \\
\text { gen. }\end{array}$ & $\begin{array}{l}\text { pron. } \\
\text { num. }\end{array}$ & $\begin{array}{l}\text { pron. } \\
\text { caso }\end{array}$ & pontuação \\
\hline \multirow{5}{*}{ B } & 1 & 4 & 4 & 1 & 1 & 0 & 1 & n/a \\
\cline { 2 - 9 } & 2 & 4 & 4 & 0 & 0 & 0 & 0 & $\mathrm{n} / \mathrm{a}$ \\
\cline { 2 - 9 } & 3 & 4 & 4 & 0 & 0 & 0 & 1 & $\mathrm{n} / \mathrm{a}$ \\
\cline { 2 - 9 } & 4 & 5 & 5 & 0 & 0 & 0 & 0 & $\mathrm{n} / \mathrm{a}$ \\
\cline { 2 - 9 } & 5 & 4 & 3 & 1 & 0 & 0 & 1 & $\mathrm{n} / \mathrm{a}$ \\
\cline { 2 - 9 } & 6 & 5 & 5 & 0 & 3 & 2 & 4 & $\mathrm{n} / \mathrm{a}$ \\
\hline
\end{tabular}

No balanço quantitativo da atividade B, relativo ao grupo B, que nos oferece esta tabela, observa-se a baixa incidência de orações com problemas de compreensibilidade ( 1 caso, já comentado, em que a oração não pode ser entendida como relativa, a saber, "ich rede immer mit meiner Ärztin, der Kopfschmerzen ich habe"), bem como apenas 2 ocorrências de erros de posição verbal, cometidos por 2 diferentes alunos que construíram as demais frases com o verbo na posição correta. Observa-se, como no caso do grupo A, que o critério caso do pronome relativo foi aquele que apresentou maiores dificuldades aos informantes, atestando, assim, o desafio que alunos brasileiros de ALE encontram no momento de declinar em alemão. 
Tabela 11 - Balanço quantitativo da atividade C, Grupo B

\begin{tabular}{|c|c|c|c|c|c|c|c|c|}
\hline atividade & informante & $\begin{array}{l}\text { total } \\
\text { frases }\end{array}$ & compreens. & $\begin{array}{l}\text { verbo } \\
\text { pos. }\end{array}$ & $\begin{array}{l}\text { pron. } \\
\text { gen. }\end{array}$ & $\begin{array}{l}\text { pron. } \\
\text { num. }\end{array}$ & $\begin{array}{l}\text { pron. } \\
\text { caso }\end{array}$ & pontuação \\
\hline \multirow{5}{*}{ B } & 1 & 2 & 1 & 0 & 1 & 0 & 1 & $\mathrm{n} / \mathrm{a}$ \\
\cline { 2 - 9 } & 2 & 2 & 1 & 0 & 0 & 0 & 0 & $\mathrm{n} / \mathrm{a}$ \\
\cline { 2 - 9 } & 3 & 2 & 1 & 0 & 0 & 0 & 0 & $\mathrm{n} / \mathrm{a}$ \\
\cline { 2 - 9 } & 4 & 2 & 0 & 0 & 0 & 0 & 0 & $\mathrm{n} / \mathrm{a}$ \\
\cline { 2 - 9 } & 5 & 2 & 1 & 0 & 0 & 0 & 0 & $\mathrm{n} / \mathrm{a}$ \\
\cline { 2 - 9 } & 6 & 2 & 2 & 0 & 1 & 0 & 2 & $\mathrm{n} / \mathrm{a}$ \\
\hline
\end{tabular}

A tabela 11 nos mostra que, na atividade $\mathrm{C}$, prevalecem erros de caso do pronome relativo, seguidos dos de gênero. $\mathrm{O}$ fator compreensibilidade se viu afetado, excepcionalmente, em todas as frases que denunciam o aparente desconhecimento, por parte de seus autores, do correlato "Roman". Não fosse esse caso, os resultados provavelmente seriam mais satisfatórios, dada a incidência majoritária de construções compreensíveis em todas as demais atividades.

Tabela 12 - Balanço quantitativo da atividade D, Grupo B

\begin{tabular}{|c|c|c|c|c|c|c|c|c|}
\hline atividade & informante & $\begin{array}{l}\text { total } \\
\text { frases }\end{array}$ & compreens. & $\begin{array}{l}\text { verbo } \\
\text { pos. }\end{array}$ & $\begin{array}{l}\text { pron. } \\
\text { gen. }\end{array}$ & $\begin{array}{l}\text { pron. } \\
\text { num. }\end{array}$ & $\begin{array}{l}\text { pron. } \\
\text { caso }\end{array}$ & pontuação \\
\hline \multirow{5}{*}{ B } & 1 & 5 & 5 & 0 & 2 & 0 & 2 & 0 \\
\cline { 2 - 9 } & 2 & 5 & 5 & 1 & 1 & 0 & 1 & 0 \\
\cline { 2 - 9 } & 3 & 4 & 4 & 0 & 0 & 0 & 0 & 0 \\
\cline { 2 - 9 } & 4 & 5 & 5 & 0 & 1 & 0 & 0 & 0 \\
\cline { 2 - 9 } & 5 & 3 & 3 & 0 & 0 & 0 & 0 & 0 \\
\hline
\end{tabular}

A tabela 11 nos mostra, assim como as anteriores, a maior incidência de problemas de caso do pronome relativo, seguidos de problemas de gênero e a ocorrência de apenas 1 erro de posição verbal. A compreensibilidade de 2 frases elaboradas pelo informante 6 se viu afetada, uma vez que não podem ser compreendidas como relativas de forma inequívoca. Também é notória a assimilação da regra de pontuação envolvida na escrita das orações relativas (seu isolamento por meio de vírgulas).

Observe-se, neste ínterim, a ocorrência de orações relativas no nominativo na atividade D. É notória a prevalência de orações dessa categoria, devido à maior facilidade dos alunos ao mobilizarem esse caso e àsua maior ocorrência na língua alemã (DÜRSCHEID, 1999). 
Tabela 13 - Orações relativas no nominativo, Grupo B, Atividade D

\begin{tabular}{|c|c|c|}
\hline Informante & Or. relativas construídas & Orações no nominativo \\
\hline $\mathbf{1}$ & 5 & 3 \\
\hline $\mathbf{2}$ & 5 & 4 \\
\hline $\mathbf{3}$ & 4 & 5 \\
\hline $\mathbf{4}$ & 5 & $\left({ }^{212}\right)$ \\
\hline $\mathbf{5}$ & 5 & \\
\hline
\end{tabular}

Adiante, proceder-se-á à análise de ocorrências de erros intra e interlinguais, assim foi feito no caso do grupo A.

Tabela 14 - Erros intra e interlinguísticos na produção geral do Grupo B

\begin{tabular}{|c|c|c|c|}
\hline $\begin{array}{c}\text { Identificação } \\
\text { (Atividade/ } \\
\text { Informante/ } \\
\text { Frase) }\end{array}$ & Erro analizado & $\begin{array}{c}\text { Intra/ } \\
\text { Inter } \\
\text { (IA/IE/ } \\
?)\end{array}$ & Subtipo \\
\hline $\mathrm{B} / 1 / 1$ & „Das ist der Mann, den suche ich“. & IA & generalização \\
\hline $\mathrm{B} / 1 / 2$ & $\begin{array}{l}\text { "Ich rede immer mit meiner Ärztin, der } \\
\text { mir hilft." }\end{array}$ & $?$ & \\
\hline $\mathrm{B} / 1 / 5$ & $\begin{array}{l}\text { „Margarinien ist ein kleines Land, das } \\
\text { ich wohnte“. }\end{array}$ & $?$ & \\
\hline $\mathrm{B} / 3 / 5$ & $\begin{array}{l}\text { „Margarinien ist ein kleines Land, das } \\
\text { meine Tante wohnte“. }\end{array}$ & $?$ & \\
\hline $\mathrm{B} / 5 / 1$ & „Das ist der Mann, den Ich mag nicht“. & IA & generalização \\
\hline $\mathrm{B} / 5 / 2$ & $\begin{array}{l}\text { „Ich rede immer mit meiner Ärztin, der } \\
\text { Kopfschmerzen ich habe". }\end{array}$ & $?$ & \\
\hline $\mathrm{B} / 5 / 5$ & $\begin{array}{l}\text { "Margarinien ist ein kleines Land, das } \\
\text { Antek wohnte". }\end{array}$ & $?$ & \\
\hline $\mathrm{B} / 6 / 1$ & $\begin{array}{l}\text { „Das ist der Mann, den Deutschkurz } \\
\text { lernt". }\end{array}$ & $?$ & \\
\hline $\mathrm{B} / 6 / 2$ & $\begin{array}{l}\text { „Ich rede immer mit meiner Ärztin, der } \\
\text { meinen Freund liebt“. }\end{array}$ & $?$ & \\
\hline $\mathrm{B} / 6 / 3$ & $\begin{array}{l}\text { „Wir haben drei Kinder, denen in } \\
\text { Schule studieren“. }\end{array}$ & $?$ & \\
\hline
\end{tabular}

${ }^{211}$ Houve uma tentativa de uso do pronome relativo no dativo, porém erroneamente empregado em posição de sujeito (“... die Bohnen, denen mir schmeckt nicht,...”), constituindo um caso do que Kleppin (1998, p. 33) denominaria supergeneralização ("die Ausweitung einer Kategorie oder Regel auf Phänomene, auf die sie nicht zutrifft”) - neste caso, manifesta na extensão do uso do dativo, exigido pelo verbo schmecken, aos seus dois complementos obrigatórios, sendo que um deles deve ser nominativo. Na terminologia de Figueiredo, F. (2004), também deparamo-nos com uma generalização.

${ }^{212}$ Análise impossibilitada devido à aleatoriedade aparente dos erros e a problemas de compreensibilidade em parte da produção. 


\begin{tabular}{|c|c|c|c|}
\hline $\mathrm{B} / 6 / 4$ & $\begin{array}{l}\text { „In der Sprachenschule, in den wir } \\
\text { lernen, ist größer." }\end{array}$ & $?$ & \\
\hline $\mathrm{B} / 6 / 5$ & $\begin{array}{l}\text { "Margarinien ist ein kleines Land, den } \\
\text { Antek Pistole wohnte“. }\end{array}$ & $?$ & \\
\hline $\mathrm{C} / 1 / \mathrm{a}$ & $\begin{array}{l}\text { „Die Geschichte von Antek Pistole ist } \\
\text { der Roman, den Besen macht". }\end{array}$ & $?$ & \\
\hline $\mathrm{C} / 1 / \mathrm{b}$ & $\begin{array}{l}\text { "Zwischen Europa und Asien liegt die } \\
\text { Türkei, das ein klein Land ist." }\end{array}$ & IA & Erro único \\
\hline $\mathrm{C} / 6 / \mathrm{a}$ & $\begin{array}{l}\text { „Die Geschichte von Antek Pistole ist } \\
\text { der Roman, den aus Margarinien ist". }\end{array}$ & $?$ & \\
\hline $\mathrm{C} / 6 / \mathrm{b}$ & $\begin{array}{l}\text { „Zwischen Europa und Asien liegt die } \\
\text { Türkei, dem in Süden ist“. }\end{array}$ & $?$ & \\
\hline $\mathrm{D} / 1 / 3$ & $\begin{array}{l}\text { "Sie wohnen in der Schweiss, den die } \\
\text { besser Schokolade produziert". }\end{array}$ & $?$ & \\
\hline $\mathrm{D} / 1 / 4$ & $\begin{array}{l}\text { „Carolina arbeitet in eine Schokolade } \\
\text { Geschäft, die auch meine Tante } \\
\text { arbeitet". }\end{array}$ & IA & \\
\hline $\mathrm{D} / 2 / 2$ & $\begin{array}{l}\text { „Die Bohnen, denen schmeckt mir } \\
\text { schlecht, waren kalt!" }\end{array}$ & IA & Erro único \\
\hline $\mathrm{D} / 4 / 3$ & $\begin{array}{l}\text { "Ich arbeite bei ein Verlag, das nur } \\
\text { Bücher produziert". }\end{array}$ & $?$ & \\
\hline $\mathrm{D} / 6 / 1$ & $\begin{array}{l}\text { „Ich habe einen Job, den sehr schlecht } \\
\text { ist". }\end{array}$ & $?$ & \\
\hline $\mathrm{D} / 6 / 2$ & $\begin{array}{l}\text { "Ich habe zur meinen Job gefahren, den } \\
\text { Job in Berlin liegt". }\end{array}$ & $?$ & \\
\hline $\mathrm{D} / 6 / 3$ & $\begin{array}{l}\text { "Ich fahre bei meinen Auto oder bei } \\
\text { Bus, den ich über die Huberstraße } \\
\text { parke". }\end{array}$ & $?$ & \\
\hline $\mathrm{D} / 6 / 4$ & $\begin{array}{l}\text { „Meinen Kollegen haben sehr } \\
\text { iteressantes aktivitätes, denen Sie den } \\
\text { Job lieben“. }\end{array}$ & $?$ & \\
\hline
\end{tabular}

Nesta tabela, pode-se observar a ocorrência de erros intralinguais que podem ser vistos como únicos, em cuja estrutura se identifica a aplicação de uma hipótese formulada com relação ao funcionamento gramatical da língua-alvo, sem que se observe a influência da língua materna. Para esses casos, pode-se também falar em uma extensão equivocada de uma regra gramatical a um elemento linguístico ao qual ela não se aplica. Tome-se como exemplo a frase „Die Bohnen, denen schmeckt mir schlecht, waren kalt!". É notório que a regra segundo a qual o verbo "schmecken" é acompanhado de um objeto no dativo, já comentada anteriormente nesta análise de dados, foi extendida ao pronome relativo, que deveria, ao exercer a função de sujeito, estar no nominativo. No caso da sentença „Zwischen Europa und Asien liegt die Türkei, das ein klein Land ist", vê-se que o pronome relativo concorda com o predicativo 
"Land" e a idéia de país (Turquia), em vez de concordar gramaticalmente com o correlato feminino (“die Türkei”, nome de país que, em alemão, faz parte de uma lista reduzida de topônimos de gênero feminino e acompanhados obrigatoriamente de artigo). No caso dos demais erros, a grande maioria, repete-se a dubiedade interpretativa que se observou quando da análise dos dados do grupo anterior: relativas preposicionadas perderam a preposição e o que seria um dativo de lugar surge simplificado no nominativo (,Margarinien ist ein kleines Land, das ich wohnte”"Margarínia é um país pequeno que eu morava"), tendência de ampla presença e inclusive dominância no português brasileiro. Porém, pode-se encarar esse mesmo erro sob uma perspectiva intralingual, em um emprego generalizado da forma nominativa "das" devido à falta de memorização das formas e usos dos pronomes relativos nos diferentes casos, gêneros e números. Essa questão foi amplamente discutida no item 3.1.1.4, e as elocubrações ali realizadas quanto aos erros aqui considerados dúbios fazse válida também nesta parte da análise. Ao intérprete de dados cabe não apenas reconhecer e identificar, mas igualmente atribuir sentidos aos dados, de tal forma que cada análise empreendida por pesquisadores distintos se mostre singular. No caso desta pesquisa, procurou-se deliberadamente abrir espaço para essas duas interpretações desse tipo de erros, uma vez que os dados de que se dispõe não se mostram suficientes para que se afirme, sem lugar a dúvidas, tratar-se exclusivamente de erros intra ou interlinguais.

No caso de „Das ist der Mann, den suche ich“, observa-se um erro intralingual, a saber, a generalização - e extensão - da regra V2 (posicionamento do verbo finito na segunda posição gramatical da frase) ao contexto da oração relativa, resultando em uma formulação que não resguarda semelhanças com a estrutura frasal portuguesa "que eu procuro” (literalmente, “den ich suche”). O mesmo ocorre com „Das ist der Mann, den Ich mag nicht “, onde não se identifica correspondência com a estrutura portuguesa, mas sim uma aplicação deslocada do posicionamento V2 na oração relativa.

Nos demais exemplos, vêem-se várias ocorrências de usos aleatórios e assistemáticos de pronomes relativos, todos tradutíveis como "que" em português (questão sumamente interlinguística), e talvez por isso pouco diferenciados, mas também se observa, no âmbito intralingual, a possibilidade de alternância de membros da mesma classe, provavelmente mal memorizados e ainda desorganizados e 
indiferenciados na memória de trabalho dos aprendizes. Trata-se, por exemplo, dos seguintes casos de uso da forma acusativa em posição/função de sujeito:

„Die Geschichte von Antek Pistole ist der Roman, den Besen macht“. (C/1/a)

„Die Geschichte von Antek Pistole ist der Roman, den aus Margarinien ist“. $(\mathrm{C} / 6 / \mathrm{a})$

„Ich habe einen Job, den sehr schlecht ist“.(D/6/1)

„Sie wohnen in der Schweiss, den die besser Schokolade produziert“. (D/1/3)

Nos seguintes casos, elaborados pelo informante 6, o dativo surge no lugar do sujeito:

„, Wir haben drei Kinder, denen in Schule studieren “. (B/6/3)

„Zwischen Europa und Asien liegt die Türkei, dem in Süden ist“. (C/6/b)

Apesar dessas duas ocorrências de erros de mesmo perfil na produção do informante 6, verifica-se que ele também empregou o acusativo em posição de sujeito, o que corrobora pela conclusão de que essa variedade aleatória no uso dos relativos denota instabilidade da interlíngua e, principalmente, conhecimento não sedimentado e dados não memorizados, uma vez que se alternam irregular e assistematicamente. Prevalecem, portanto, erros dúbios que podem ser ocasionados pela influência do generalizado "que" português, bem como pode ser o caso de alternância de membros da mesma classe ou mesmo de confusão entre termos lexicais semelhantes.

Uma vez desenvolvida a análise dos dados dos dois grupos, proceder-se-á, nas considerações finais que se seguem, à retomada e verificação das perguntas de pesquisa, da hipótese inicial e das hipóteses levantadas durante a interpretação dos dados. 
5. CONSIDERAÇÕES FINAIS 
A memória filtra, distorce, seleciona e, por vezes, cuida afetivamente melhor de algumas coisas do que de outras. Dependendo das circunstâncias, mente e engana. Não segue procedimentos e instruções claros para guardar ou atirar fora um acontecimento vivido. Às vezes, insiste em ver as mesmas coisas em coisas diferentes.

(ANDRÉ et al., 2006, p. 29)

A condução desta pesquisa foi motivada por inquietações, intuições e curiosidades que refletem aspectos de minha prática docente no âmbito de ALE, bem como meu repertório de crenças. Também entraram em jogo minhas intuições linguísticas como falante nativo de português brasileiro e como falante de alemão como língua estrangeira ${ }^{213}$. O trabalho com diferentes LDs levou-me a observar diferenças entre eles, de modo especial no tocante à progressão dos tópicos de natureza gramatical. Uma análise dos dois manuais mais empregados para o ensino de ALE no estado de São Paulo, Schritte International e studio $d$, leva-nos a reconhecer que, se no primeiro os temas gramaticais, com foco especial no tema aqui abordado, i.e., as orações relativas, são apresentados ao aluno (e ao professor) em blocos, no segundo, ao contrário, são diluídos ao longo das lições, com revisões esporádicas entre as diferentes unidades. Segundo a terminologia de Wilkins (1978), trata-se das abordagens analítica e sintética da progressão de conteúdos gramaticais.

Para a elaboração deste trabalho, considerou-se fundamental relevar discursos que importantes estudiosos teceram (e tecem) a respeito do aprendizado de LE no âmbito da psicolinguística, com ênfase especial na proposta da existência de duas instâncias principais da memória humana, a saber, a dicotomia memória de trabalho/curta duração $o^{214}$ e memória de longa duração. Todo o processo de aprendizagem de LE é permeado pela questão da(s) memória(s). Observa-se a necessidade de que os aprendizes memorizem vocábulos, regras gramaticais, chunks e, enfim, a forma de se dizer as coisas na língua do outro, e interrelacionar esses saberes armazenados. Entre as principais dificuldades que estudantes de ALE apontam, em sala

\footnotetext{
${ }^{213}$ É evidente que, como falante de ALE, tendo aprendido a língua a partir dos 14 anos, não possuo o mesmo referencial de julgamento de (a)gramaticalidade de um falante nativo (e, como já foi apontado,anteriormente, mesmo esse referencial é questionável); entretanto, devido ao fato de os alunos se situarem, linguisticamente, entre os níveis A2 e B1 do QECR, e devido ao meu longo contato com a interlíngua de brasileiros que estudam ALE, meus conhecimentos (C2) me pareceram suficientes para analisar suas construções, ainda que a perfeição absoluta não possa ser atingida (o que se deve, também, à falibilidade do pensamento humano, de forma geral). Kenedy (2009) nos fala do emprego da intuição de falantes (no caso, nativos) na pesquisa linguística sobre as orações relativas.

${ }^{214}$ Distinções, semelhanças e interrelações entre ambas são discutidas no capítulo 1 desta dissertação.
} 
de aula e em pesquisas sobre suas crenças realizadas por professores com vistas a melhor conhecer seu alunado, encontram-se a memorização do vocabulário dessa língua, em geral pouco transparente para falantes de português, a associação artigo + substantivo e as declinações de artigos, pronomes, adjetivos etc. A dificuldade de memorização, tanto do vocabulário quanto das regras de funcionamento e dos paradigmas flexionais da língua alemã (sua gramática), não pode ser menosprezada quando se considera o processo global de ensino-aprendizagem dessa língua. Pelo contrário, é preciso que seja abordada de forma direta por educadores, dada sua ubiquidade nesse processo.

Os modos como os temas gramaticais são apresentados nos dois LDs empregados pelas instituições onde lecionam os professores-voluntários desta pesquisa querem-me parecer especialmente associados à ativação das memórias no processo de ensino-aprendizagem. A proposta dos autores de Schritte, ao apresentarem aos alunos as orações relativas alemãs com pronomes no nominativo, acusativo e dativo, de uma só vez, representa um desafio maior à limitada memória de trabalho, uma vez que obriga o aprendiz a memorizar e mobilizar um grande volume de conhecimentos em uma mesma ocasião (doze formas de pronomes relativos, com seus sentidos e funções). Isso pode gerar uma sobrecarga da memória de trabalho e dificuldades na feitura de exercícios de fixação - sem consulta - aplicados imediatamente após o ensino-aprendizagem da estrutura. Apesar disso, vale lembrar que os pronomes relativos em questão correspondem às formas dos artigos definidos alemães, tema trabalhado vários estágios antes, em curso, e com maiores probabilidades de já estar armazenado na memória de longa duração dos aprendizes.

Em studio $d$, de forma dessemelhante, as orações relativas alemãs no nominativo, acusativo e dativo são abordadas separadamente, aos poucos, e com várias unidades situadas entre a apresentação dos dois primeiros casos (tratados em aulas diferentes pelo professor-voluntáro) e a do terceiro, cenário que deveria viabilizar o depósito na memória de longa duração, via prática e revisão, desses conteúdos abordados paulatinamente. $\mathrm{Na}$ aula em que esses aprendentes foram expostos aos pronomes relativos alemães no dativo, eles já deveriam contar com informação depositada em suas memórias de longa duração acerca do funcionamento geral das orações relativas, bem como suas formas no nominativo e acusativo e, como no caso do 
outro grupo, já lhes haviam sido apresentadas as formas dos artigos definidos alemães nesses três casos gramaticais.

Apesar dessas considerações, ao definir a hipótese de trabalho a partir da qual se entreteceu esta pesquisa, tive de considerar os prós e contras de cada abordagem, assim como observados por mim durante minha prática docente. Ao passo que a abordagem sintética parecia a mais adequada para que o aluno tivesse a oportunidade de memorizar e praticar aos poucos o conhecimento gramatical, dispondo de informação depositada na memória de longa duração acerca do fenômeno em que pudesse ancorar o novo conhecimento que se lhe propunha, também é verdade que oferece ao aluno mais espaço para o esquecimento daquilo que lhe foi ensinado meses antes. É que, como conclui Stanich (2008, p. 136) a partir dos experimentos conduzidos em sua pesquisa doutoral, e contrariando McLaughlin (1978), "o simples fato de uma informação sobre a língua estar presente na memória de longa duração não faz com que ela seja utilizada de forma automática durante a produção em LE”.

A abordagem analítica, em seu turno, não abre esse espaço para o esquecimento, mas pode levar à sobrecarga da memória de trabalho do aprendiz, dificultando o processo de ensino-aprendizagem da complexa estrutura em questão. A análise dos dados leva-nos a confirmar a validez dessa hipótese inicial. As orações relativas construídas pelos alunos do grupo B, que as aprenderam mediante a adoção da proposta pedagógica de studio d (sintética), concentram um número sutilmente maior de acertos, da ordem dos 10\%, o que não nos permite bradar sua suposta superioridade. Além disso, a presença de infomantes cuja produção destoava da média, na mesma turma, dificulta a elocubração de asserções definitivas acerca do rendimento de cada grupo. No grupo B, uma informante cometeu erros primários (diretamente relacionados à estrutura oração relativa, a saber, de posição do verbo e flexão do pronome relativo) em absolutamente todas as orações que construiu ${ }^{215}$. No grupo A, o informante 1 se destacou por um volume de erros superior à média. Isso aponta para uma limitação deste trabalho, a saber, o número relativamente reduzido de informantes ${ }^{216}$. Apesar disso, e a despeito

\footnotetext{
${ }^{215}$ No caso, erros concentrados no pronome relativo.

${ }^{216}$ É importante ressaltar, todavia, que a questão do número de informantes foi uma das primeiras a serem discutidas durante a arguição do projeto de pesquisa quando de meu ingresso no programa de pósgraduação. Essa quantidade de informantes foi considerada suficiente, pela banca de arguição do projeto,
} 
desse aspecto, demonstrarei na sequência que esta pesquisa me possibilitou chegar a importantes conclusões e também formular instigantes perguntas acerca dos dois processos de ensino-aprendizagem das relativas.

Os erros primários cometidos pelos alunos dos dois grupos reafirmam a natureza instável de sua interlíngua, com ocorrências de um mesmo informante elaborando orações relativas com o verbo corretamente situado ao final da frase, mas também outras em que o verbo aparece na posição 2 (reveja-se o conceito de recaída, de Selinker, no item 1.1.3), em casos nos quais pode ter ocorrido tanto a influência da estrutura oracional canônica das orações declarativas (e principais) alemãs, como uma interferência da estrutura SVO do português. A maioria dos erros se concentrou, entretanto, no pronome relativo, onde se observaram dificuldades sobretudo em sua flexão de caso, tema consabidamente problemático para aprendizes brasileiros. Chama a atenção, neste ínterim, a falta de uma sistematização no uso observado dos relativos junto aos alunos que os empregaram incorretamente. Nesses casos, seu uso se apresenta de forma aleatória, com a mesma forma funcionando ora como sujeito, ora como objeto, de modo que se poderia denominar "sistematicamente assistemático". Por isso, ao menos se levarmos em consideração os dados aos que se teve acesso (e há-se de fazêlo), esses erros não se mostraram sistemáticos e consistentes como quereria Corder (1967). Isso denota uma dificuldade acentuada de memorização das formas e funções dos pronomes relativos alemães, bem como a possível influência da forma de uso generalizado "que" em português brasileiro e a escassez do emprego das relativas preposicionadas na língua falada neste país. Como se observou durante a análise dos dados, os erros primários na construção das orações relativas, de forma geral e em sua maioria, não impedem a compreensão dos enunciados, o que pode fazer com que os aprendizes não atribuam maior importância ou ênfase na diferenciação precisa de suas formas.

\footnotetext{
para o escopo de um trabalho de mestrado, e gerou uma média de 140 construções a analisar. Também é conveniente lembrar que, em uma das duas escolas em que se conduziu a coleta de dados, havia apenas um grupo trabalhando a primeira metade de Schritte International 5 e que poderia, assim, participar da pesquisa. No semestre seguinte, não se formou nenhuma turma desse nível na escola, e, quando formados, os grupos costumam ter de 4 a 8 alunos presentes, apenas. Do mesmo modo, na outra escola as turmas desse nível são escassas e mesclar dados de informantes de diferentes turmas, que estariam tendo aulas com outro professor, cujo trabalho possivelmente se caracterizaria por outras práticas, não me pareceu conveniente com vistas à realização de uma pesquisa acurada. Assim, o número reduzido de participantes também é decorrência das limitadas opções de acesso a eles de que se dispunha.
} 
A análise dos dados instigou a formulação de hipóteses adicionais acerca do fenômeno pesquisado. A primeira delas advém da observação de que a maior parte dos acertos dos membros de ambos os grupos se deu na construção de orações relativas no nominativo. A despeito da maior incidência do nominativo, de forma geral, nos discursos em língua alemã, é notório que esse caso, como forma-base do alemão, é o primeiro com o qual travam contato aprendizes de ALE, de modo que as formas der/die/das/die lhes sejam conhecidas desde o início dos estudos dessa língua e representem-lhes, assim, um menor grau de dificuldade. Ao construir orações relativas com pronome no nominativo, é como se os alunos não estivessem declinando, i.e., não tivessem que mobilizar a flexão de caso que tantas dificuldades lhes traz.

Outra hipótese formulada a partir do que nos mostram os dados refere-se à dubiedade de grande parte dos erros encontrados no corpus, que podem ser entendidos como intra ou interlinguais. No caso de uma oração como „Margarinien ist ein kleines Land, das Antek Pistole wohnte" (B/3/5), pode-se supor tanto que tenha havido uma influência do uso indiscriminado da forma portuguesa "que" nas relativas comumente construídas por brasileiros, substituindo, inclusive, as relativas preposicionadas da norma culta, como também uma indiferenciação de formas do pronome relativo alemão, mediante o uso de uma forma regular ou neutra (nominativo) num lugar reservado ao dativo, após preposição. Para chegar a uma certeza a respeito desse fato, seria necessário retornar aos informantes e investigar, em uma entrevista, as motivações de seus erros ou, de forma mais segura, fazer coletas mais extensivas de sua produção linguística, nas formas escrita e oral. Apesar disso, proceder a essas ações implicaria a condução de outra pesquisa, de outro feitio e natureza, o que não correspondia aos meus objetivos iniciais e ao escopo de um trabalho de mestrado. Toda pesquisa possui (e deve possuir), entretanto, suas limitações, abrindo espaço para que outros pesquisadores interessados no tema dêem prosseguimento às investigações desse fenômeno e busquem respostas a outras perguntas formuladas a partir da leitura deste trabalho.

Também é possível hipotetizar que o fato de os alunos terem construído majoritariamente, e malgrado a incidência de erros primários, orações relativas em alemão que cumprem com as funções semântico-pragmáticas reservadas a essa estrutura e são, por isso, compreensíveis, se deve à semelhança semântica e pragmático-funcional 
das relativas alemãs e brasileiras, em ambos os casos servindo para explicar e especificar ou restringir um elemento nominal (correlato) da oração anterior (principal).

Finalmente, observou-se que a questão da posição do verbo nas subordinadas alemãs, entre as quais se incluem as relativas, representou relativamente pouca dificuldade para os aprendizes dos dois grupos, sendo que os poucos casos de erros associados a esse detalhe são da autoria de alunos que também situaram o verbo, de forma correta, ao final de outras relativas que construíram, o que aponta mais para a instabilidade própria da interlíngua dos aprendizes (com as típicas "recaídas" de Selinker, 1992), que também assim se manifesta, que para problemas de assimilação desse aspecto gramatical. Esse fato, analisado à luz do que propõe a Teoria da Processabilidade, mostra que, ao menos na forma escrita, os informantes da pesquisa parecem ter assimilado a última estrutura do continuum proposto por Pienemann. Por outro lado, a flexão do pronome demonstrou ser mais problemática, e, como já era esperado, a sua declinação ou flexão de caso foi o aspecto que representou um maior desafio para os estudantes e que concentrou maior ocorrência de erros, seguido da questão gênero, embora tenha-se observado, em diversos casos, que houve troca do gênero do pronome devido a um engano na identificação do gênero do correlato, havendo, assim, concordância a despeito do erro. A prática profissional me mostrou, entretanto, que a competência gramatical exibida pelos alunos em sua produção escrita e oral difere enormemente, de modo que uma pesquisa para a qual se coletassem amostras de sua produção falada levaria a outras conclusões acerca da assimilação/aprendizagem/aquisição dessa e de outras estruturas.

A realização desta pesquisa teve como norte e objetivo a busca de respostas às perguntas de pesquisa que me propus desde o início da investigação. Verifiquemos, pois, os resultados a que nos levaram o experimento e a análise dos dados.

1. Quanto às diferenças, durante a realização de exercícios escritos, entre a produção de alunos que aprenderam as orações relativas de acordo com as abordagens sintética ou analítica: Não foram observadas diferenças significativas entre a produção de um e de outro grupo, embora se tenha registrado uma incidência um pouco menor (da ordem dos 10\%) de erros entre os informantes do grupo que abordou as relativas sob a perspectiva 
sintética. Mais do que evidências quanto à maior eficácia de uma ou outra abordagem, os dados nos mostram, inclusive devido à presença de perfis destoantes entre as produções dos alunos do mesmo grupo, que uma pesquisa com um número maior de informantes poderia nos levar a uma comparação mais aperfeiçoada dos dois processos. Ao mesmo tempo, a análise dos dados disponíveis, como recentemente se afirmou, serviu para confirmar a hipótese incial: não parece haver uma superioridade no emprego de uma ou outra perspectiva, apresentando cada uma delas seus prós e contras.

2. Os LD Schritte International e studio d levam a resultados de aprendizagem díspares ou semelhantes? Havendo diferenças no aprendizado dessas estruturas entre um e outro grupo, como elas se manifestam e que perfil assumem? Como observado nos comentários referentes à pergunta de pesquisa 1, não é possível tecer comentários comparativos seguros quanto aos resultados do uso de um ou outro material.

3. Existem divergências de rendimento, na produção de um mesmo grupo de aprendizes e, inclusive, de um mesmo aluno, entre exercícios de feitio mais e menos controlado, ou mais e menos (re)produtivos? (cf. tipologia de NEUNER et al., 1981)? Em partes, sim. Todos os alunos, dos dois grupos, demonstraram desempenho maior na atividade de tipo A, tipicamente reprodutiva, enquanto que suas dificuldades foram-se pronunciando nas demais atividades, nas quais se esperava a construção de orações relativas. A atividade $\mathrm{B}$ ofereceu maiores dificuldades a alguns informantes porque $\mathrm{o}$ pronome relativo era proposto de antemão, forçando um tipo de construção a que talvez o aluno não estivesse afeito, e, no caso da frase 4 desse exercício, a presença de dois espaços, reservados para uma combinação preposição + relativo, fez com que alguns informantes não a construíssem. A atividade D, mais livre, também foi aquela em que os aprendentes puderam decidir, sem interferência externa, a natureza das orações que elaborariam e, assim, investiram majoritariamente nas orações com pronome relativo no nominativo, o que lhes angariou uma taxa maior de acertos. Na atividade B, a presença do correlato "Roman" (romance) parece ter induzido a erros de 
natureza semântico-pragmática, provavelmente devido à confusão de seu significado com o falso amigo "romano".

4. A apresentação analítica das orações relativas no nominativo, acusativo e dativo, num único bloco, em Schritte International, parece ocasionar, durante a realização dos exercícios, uma sobrecarga da memória de trabalho, de acordo com os fundamentos teóricos discutidos na parte primeira desta dissertação, que transpareça a partir do que se observa em sua produção linguística escrita, contrastada com a do outro grupo (studio d)? A falta de sistematização dos numerosos erros de declinação dos pronomes relativos denotou, no caso dos dois grupos, problemas de memorização de suas formas e funções. O grande volume de informação nova parece ter excedido a capacidade de memorização imediata dos aprendizes de ambos os grupos, apesar do fato de os participantes do grupo B terem tido a oportunidade de conhecer as relativas no nominativo e no acusativo meses antes, bem como os artigos definidos no dativo.

Cumpriram-se, assim, os objetivos explicitados na introdução deste trabalho, ainda que nem sempre as análises empreendidas tenham conduzido a uma resposta precisa localizada em um dos pólos do binômio sim-não: 1. Determinar a diferença entre a produção escrita de alunos que tenham aprendido as orações relativas a partir das abordagens de progressão gramatical; 2. Identificar diferenças significativas na produção de cada grupo, analisando seu desempenho nos exercícios de cada tipo; 3. Comparar as amostras de produção linguística escrita dos dois grupos de informantes e dos diferentes alunos dentro de cada grupo, descrever as semelhanças e diferenças entre elas e, a partir disso, chegar a conclusões analíticas fundamentadas no referencial teórico da dissertação; 4. Relacionar as distintas abordagens de progressão gramatical à ativação das duas principais instâncias da memória; 5. Formular novas hipóteses motivadas pela análise dos dados.

Apesar disso, algumas perguntas permanecem em aberto após a realização desta pesquisa: 
- Que dados nos ofereceria um corpus mais robusto, que incluísse amostras de produção linguageira oral? Acredito que a produção oral, cuja realização é mais imediata e ágil, oferece reflexos mais claros de quais conhecimentos se automatizaram ou estão em vias de automatizar-se, ao contrário da produção escrita, que se delonga no tempo e dá mais espaço para o aprendiz recorrer aos seus conhecimentos declarativos antes de escrever.

- Caso fosse possível o acesso a turmas mais numerosas, haveria diferenças nas evidências fornecidas pelos dados? Aqui se observa, com referência a uma das hipóteses de trabalho esboçadas na introdução, que o número reduzido de informantes não permite a confecção de asserções seguras a respeito de um suposto perfil ou nível geral registrado na produção dos alunos de cada grupo. Com apenas seis informantes, obtiveram-se registros dissoantes, com alunos afastando-se da média devido à (quase) ausência de erros ou à predominância deles em suas construções e textos, restando, assim, tão somente quatro informantes com um suposto rendimento mediano por grupo, o que, por um lado, dificulta a investigação, mas, por outro, confirma a hipótese principal acerca da possível semelhança entre as produções de ambos os grupos.

- Entrevistas de autoconfrontação com os informantes, a posteriori, poderiam nos levar a maiores conclusões sobre as motivações de seus erros e enganos?

- Se se procedesse à realização do que McKay (2006, p. 60) denomina "introspective research" na forma de "verbal reports" (gravações de pensamentos elocubrados oralmente por estudantes enquanto realizam tarefas ou imediatamente após sua realização), poderíamos chegar a maiores conclusões acerca da natureza e das razões de seus erros? Essa medida deveria ser tomada, entretanto, com um número menor de informantes, caso fosse realizada durante uma pesquisa de mestrado, devido ao volume e complexidade dos dados que ofereceria para análise.

Essas perguntas poderão ser perquiridas por eventuais pesquisadores interessados na temática deste trabalho. 
Uma pergunta que me foi proposta espontanemante pelos dois professoresvoluntários desta pesquisa, após as entrevistas, referia-se à minha opinião pessoal acerca de qual das duas propostas de progressão de tópicos gramaticais em cursos de ALE viria a ser a mais adequada para facilitar a mediação da construção de conhecimento. Como lhes disse por ocasião de nossas interlocuções, os dados obtidos não me permitem oferecer uma resposta a essa indagação com embasamento científico e empírico. Malgrado esse fato, além das intuições iniciais que inspiraram a formulação da problemática de pesquisa e da hipótese inicial, o processo de construção deste trabalho e o próprio fato de a perscrutação de algumas questões não ter conduzido a respostas claras ou definitivas funcionam como inspiração para a conformação de outras intuições e hipóteses.

A mais importante delas, não respondível através desta pesquisa, uma vez que a sucede, consiste na consideração de que a exploração sintética dos tópicos gramaticais, desde que caracterizada por sucessivas revisões dos fragmentos de conteúdos previamente abordados entre uma fase de apresentação de novo insumo e outra, deveria levar a uma assimilação qualitativamente mais satisfatória do tópico gramatical em questão por parte do alunado, uma vez que a aquisição de novos conhecimentos sempre terá por base a retomada de informações anteriormente aprendidas, ou seja, o novo conhecimento será sempre ancorado naqueles que o aluno já possuía sobre o mesmo tema. Entretanto, há-se de admitir que apenas mediante o acesso a um número elevado de informantes em cada grupo poder-se-ia (quiçá) chegar a conclusões mais contundentes acerca dessa problemática. Seria necessária, assim e de todos os modos, a condução de uma nova pesquisa. Essa nova proposta de investigação, entrementes, há de chocar-se com a dificuldade encontrada, junto às instituições de ensino que oferecem cursos livres de ALE, de encontrarem-se turmas com um número não reduzido de alunos. Uma alternativa seria, talvez, a aplicação dos testes junto a alunos de língua alemã nas disciplinas de graduação dos cursos de Letras de nossas universidades públicas, uma vez que se contabilizam, comumente, mais de 20 participantes nesses grupos. Seria necessário, porém, refletir detidamente acerca dos eventuais detalhes dessa eventual pesquisa.

Espera-se, para concluir este texto, que se tenha oferecido a professores e pesquisadores da área de ALE material para provocar reflexões e ponderações de 
variada monta acerca do ensino de gramática dessa língua mediante a adoção de livros didáticos disponíveis em nosso mercado editorial e amplamente utilizados. Esta pesquisa pretendeu consistir, assim, em um pontapé inicial para os estudos acerca do ensino-aprendizagem das orações relativas alemãs por parte de aprendizes brasileiros no país e das diferentes propostas de progressões de tópicos gramaticais encontradas em LDs de ALE. Apesar de outros trabalhos poderem abarcar aspectos que, nesta dissertação, não se prendia circunscrever, e de outras pesquisas poderem eventualmente encontrar respostas às perguntas que permaceram abertas ou que se responderam timidamente com a conclusão deste experimento, creio ser importante ressaltar a dificuldade inerente ao trabalho de análise da produção linguística de aprendizes de LE, uma vez que, como descrevem André et al., o processo de (ensino)-aprendizagem é multifatorial e muitos dos fatores que nele influenciam não emergem necessariamente a partir dos dados coletados:

O aprender envolve atribuir significações e engendra relações únicas com o saber. Mobiliza experiências vividas pelo sujeito, em sua interação com outros significativos e em sua inserção no mundo. É um processo permeado por afetos, desejos, expectativas, vontades, os quais interferem na aprendizagem e também são aprendidos. (ANDRÉ et al., 2006, p. 86)

Com o aprendizado sendo um fenômeno psicossocial e afetivo, entre outros adjetivos que se lhe pode atribuir, ainda nos deparamos, no estado atual dos estudos relacionados à aprendizagem, com aquilo a que os behavioristas se referiam como sendo a "caixa preta", aquelas questões que também se podem denominar intrapsicológicas, ou o que não se pode observar e tanger de forma completa e que não deixe lugar a dúvidas. A psicolinguística, da qual me vali na confecção deste trabalho, a ciência cognitiva, a psicologia da educação e outras disciplinas vêm-se mobilizando de forma altamente interessante com vistas a iluminar e explorar essa caixa - tanto o seu interior quanto o que a partir dela se produz.

Assim, concluo que o futuro dos estudos acerca dos processos de ensinoaprendizagem, quer seja os dedicados à minha temática específica, quer seja os que contemplem outros objetos, de forma geral, reside nos métodos e fazeres inter, multi e transdisciplinares - "afinal, a linguagem é o maior empreendimento conjunto do ser humano e não pode ser cercado de um lado apenas" (MARCUSCHI; SALOMÃO, 
2004, p. 15) - e a Linguística Aplicada, dado o seu hibridismo, firmou-se como um ponto de partida privilegiado para tal. 
REFERÊNCIAS 
ABAURRE, M. et al. Português: língua e literatura. Volume único. São Paulo: Moderna, 2003.

AUFDERSTRASSE, H. et al. Themen neu 1; Kursbuch. Ismaning: Max Hueber, 1994.

ALMEIDA FILHO, J. C. P. Linguística aplicada; ensino de línguas e comunicação. Campinas: Pontes Editores e ArteLíngua, 2005.

ALLWRIGHT, D.; BAILEY, K. M. Focus on the language classroom. Cambridge: Cambridge University Press, 1991.

ALVAREZ, M. L. O. A transferência, a interferência e a interlíngua no ensino de línguas próximas. An. 2. Congr. Bras. Hispanistas Oct. 2002. Disponível em: < http://www.proceedings.scielo.br/scielo.php?pid=MSC0000000012002000100039\&scri pt=sci_arttext $>$, último acesso em: 25 mar. 2014.

ANDERSON, J. Cognitive psychology and its implications. New York: Freeman, 1985.

The architecture of cognition. Cambridge: Harvard University Press, 1983.

ANDRÉ, M. E. D. A. et al. "Fios que se entrelaçam: a função da memória na aprendizagem de adultos". In: PLACCO, V. M. N.; SOUZA, V. L. T. (Orgs.). Aprendizagem do adulto professor. São Paulo: Loyola, 2006. p. 25-39.

BADDELEY, A. Human memory; theory and practice. Mahwah: Lawrence Earlbaum, 1990.

et al. Memória. Porto Alegre: Artmed, 2011.

BAZARIM, M. Metodologias de pesquisa aplicadas ao contexto de ensinoaprendizagem de línguas. XII Congresso Nacional de Linguística e Filologia - Livro dos Minicursos Extras. Rio de Janeiro: CiFEFIL, 2008. p. 93-102.

BECHARA, E. Moderna gramática da lingua portuguesa. São Paulo: Lucerna, 2010.

BENNETT, W. A. "The importance of error". In: Applied linguistics and language learning. London: Hutchinson Educational, 1974. p. 228-250.

BETTERMANN, C. et al. studio d Al; Unterrichtsvorbereitung. Berlin: Cornelsen, 2005.

BIALYSTOK, E. A theoretical model of second language learning. Language learning 28, 1978. p. 69-83.

. "Metalinguistic dimensions of bilingual language proficiency". In:

Language processing in bilingual children. Cambridge: Cambridge University Press, 1991. p. 113-140.

BIANCHINI, S. M. S. As concepções de erros no ensino de línguas. Anais do VI Congresso de Letras "Linguagem e Cultura: Múltiplos olhares", 2007. p. 1-10. 
BIMMEL, P.; RAMPILLON, U. Lernerautonomie und Lernstrategien. Berlin et al.: Langenscheidt, 2000.

BIMMEL, P.; KAST, B.; NEUNER; G. Deutschunterricht planen neu. Berlin et. al.: Langenscheidt, 2011.

BONA, A. A reversão da fossilização em aprendizes adultos de L2 através do fornecimento de feedback corretivo. Anais do CELSUL 2008, p. 1-14.

BORGES, E. F. V. Metodologia, abordagem e pedagogias de ensino de língua(s). Linguagem e Ensino, Pelotas, v. 13, n. 2, 2010. p. 397-414.

BRESNAN, J. The mental representations of grammatical relations. Cambridge: MIT Press, 1982.

BUSSMANN, H. Lexikon der Sprachwissenschaft. Stuttgart: Kröner, 2008.

CAGLIARI, L. Alfabetização e linguística. São Paulo: Scipione, 1996.

CAMARA Jr., J. M.. Estrutura da língua portuguesa. Petrópolis: Vozes, 1986.

Dicionário de linguística e gramática referente à língua portuguesa. São Paulo: Vozes, 1997.

CANUTO, M. Atividade de formação de professores de ensino fundamental I; leitura como instrumento de ensino-aprendizagem. Dissertação (Mestrado em Linguística Aplicada e Estudos da Linguagem). São Paulo: PUC-SP, 2012.

CASTILHO, A. T. "O que se entende por língua e gramática". In: Nova gramática do português brasileiro. São Paulo: Contexto, 2010.

CAVALARI, S. M. S. O gerenciamento do erro em aulas de inglês como língua estrangeira: um estudo com foco na produção oral. Trabalhos em Linguística Aplicada, 47 (1), Jan./Jul. 2008, p. 45-63.

CAVALCANTI, M. C. "Reflexões sobre a prática como fonte de temas para projetos de pesquisa para a formação de professores de LE”. In: ALMEIDA FILHO, J. C. (Org.). $O$ professor de língua estrangeira em formação. Campinas: Pontes, 2009. p. 179-184.

CEGALlA, D. P. Novíssima gramática da língua portuguesa. São Paulo: Cia. Editora Nacional, 1998.

CELANI, M. A. A. Questões de ética na pesquisa em linguística aplicada. Linguagem \& Ensino, vol. 8, n 1, 2005. p. 101-122.

CHOMSKY, N. Syntactic Structures. Berlin/New York: de Gruyter, 2002 [1957].

CLAHSEN, H. "The acquisition of German word order; a test case for cognitive approaches to second language acquisition". In: ANDERSEN, R. (Org.). Second languages. Rowley: Mass, 1984. 
CLAHSEN, H.; MEISEL, J.; PIENEMANN, M. Deutsch als Zweitsprache; der Spracherwerb ausländischer Arbeiter. Tübingen: G. Narr, 1983.

CONSELHO DA EUROPA. Quadro europeu comum de referência para as línguas; aprendizagem, ensino, avaliação. Porto: Edições Asa, 2001.

CORACINI, M. J. "O livro didático nos discursos da linguística aplicada e da sala de aula". In: . (Org.). Interpretação, autoria e legitimação do livro didático; língua materna e língua estrangeira. Campinas: Pontes, 1999.

CORDER, P. S. The significance of learners errors. International Review of Applied Linguistics, 5, 1967. p. 161-169.

115-124.

Approximative systems of foreign language learners. IRAL, v. 9, $\mathrm{n}^{\circ} .2,1971$. $\mathrm{p}$.

COSERIU, E. Lições de linguística geral. Rio de Janeiro: Ao Livro Técnico, 1980.

Introducción a la lingüística. Madrid: Centro de Lingüística Hispánica, 1986.

CUNHA, C.; CINTRA, L. Nova gramática do português contemporâneo. Rio de Janeiro: Nova Fronteira, 1985.

CUNHA, M. C. C. Análise de estratégias de ensino/aprendizagem em materiais didáticos de alemão como língua estrangeira; perspectivas pós-comunicativas em contraste. Dissertação (Mestrado em Língua e Literatura Alemã). São Paulo: USP, 2013.

DEESE, J. Psicolinguística. Rio de Janeiro: Vozes, 1970.

DE GRANDE, P. B. O pesquisador interpretativo e a postura ética em pesquisas em linguística aplicada. Eletras, vol. 23, n 23, 2011. p. 11-27.

DIEHL, E.; PISTORIUS, H.; DIETL, A. "Grammatikerwerb im Fremdsprachenunterricht - ein Widerspruch in sich?" In: BÖRNER, W.; VOGEL, K. (Orgs.). Grammatik und Fremdsprachenerwerb; kognitive, psycholinguistische und erwerbstheoretische Perspektiven. Tübingen: Narr, 2002. p. 143-163.

DUDEN. Die Grammatik; Grammatik der deutschen Gegenwartssprache. Band 4. Mannheim: Bibliographisches Institut, 1998.

DÜRSCHEID, C. Die Verbalen Kasus des Deutschen. Berlin/New York: De Gruyter, 1999.

Syntax; Grundlagen und Theorien. Göttingen: Vandenhoeck \& Ruprecht, 2007.

EDMONDSON, W. "Wissen, Können, Lernen - kognitive Verarbeitung und Grammatikentwicklung". In: BÖRNER, W. \& K. VOGEL (Orgs.) Grammatik und Fremdsprachenerwerb. Tübingen: Narr, 2002. p. 51-70. 
EDMONDSON, W.; HOUSE, J. Einführung in die Sprachlehrforschung. Tübingen \& Basel: A. Francke Verlag, 2006.

EISENBERG, Peter. Grundriss der deutschen Grammatik. Stuttgart: J.B Verlag, 1994.

ELLIS, R. Second language acquisition. Oxford: Oxford University Press, 2003.

2006 The study of second language acquisition. Oxford: Oxford University Press, Understanding second language acquisition. Hong Kong: Oxford University Press, 1987.

FELIX, S. W. Psycholinguistische Aspekte des Zweitsprachenerwerbs. Tübingen: Narr, 1982.

FERNÁNDEZ, Y. A presença de erros na interlíngua de estudantes brasileiros aprendizes de espanhol. Desempenho, v. 12, n 1, junho 2011. p. 1-27.

FERRARI, B. Alemão como segunda língua estrangeira para aprendizes brasileiros; a influência do inglês em um contexto de aprendizagem plurilíngue. Dissertação (Mestrado em Língua e Literatura Alemã). São Paulo: USP, 2012.

FIGUEIREDO, F. J. Q. Aprendendo com os erros; uma perspectiva comunicativa de ensino de línguas. $2^{\mathrm{a}}$ ed. rev. amp. Goiânia: Editora UFG, 2004.

$39-57$.

Aquisição e aprendizagem de segunda língua. Signótica, v. 7, jan/dez 1995. p.

FIGUEIREDO, R. M. B. Observações sobre construção de conhecimento. Soletras, v. 7 , $\mathrm{n}^{\circ} 13,2007$. p. 77-96.

FLIEGNER, J. Grammatik verstehen und gebrauchen. Frankfurt/Main: Scriptor, 1986.

FONTANA, B.; LIMA, M. S. Questões centrais do ensino e da aprendizagem de línguas estrangeiras. Em Aberto, v. 22, n 81, 2009. p. 15-29.

FUNK, H. "Materialentwicklung". In: HALLET, W.; KÖNIGS, F. (Orgs.). Handbuch Fremdsprachendidaktik. Seelze-Velber: Kallmeyer/Klett, 2010.

FUNK, H.; KUHN, C.; DEMME, S. studio d A2; Deutsch als Fremdsprache. Kurs- und Übungsbuch (Gesamtband). Berlin: Cornelsen, 2010. studio d A2; Deutsch als Fremdsprache. Kurs- und Übungsbuch (Teilband I). Berlin: Cornelsen, 2010a. studio d A2; Lehrerhandbuch. Berlin: Cornelsen, 2010b.

GASS, S. M. Language universals and second language acquisition. Language Learning, v. 39, 1989. p. 497-534. 
GASS, S.; SELINKER, M. Second language acquisition; an introductory course. London: Routhledge, 2008.

GNUTZMANN, C. “'Das geht doch nicht, oder?' - Grammatik für Lehrende". In: BÖRNER, W. \& K. VOGEL. Grammatik lehren und lernen. Didaktisch-methodische und unterrichtspraktische Aspekte. Bochum: AKS-Verlag, 2001. p. 9-26.

GOMES, E. J. Qual o papel da gramática na aprendizagem do francês língua estrangeira em contexto universitário? Tese (Doutorado em Estudos Linguísticos, Literários e Tradutológicos em Francês). São Paulo: FFLCH/USP, 2011.

GRAUBERG, W. The elements of foreign language teaching. Clevedon: Multilingual Matters, 1997.

HARDEN, T. Angewandte Linguistik und Fremdsprachendidaktik. Tübingen: Narr, 2006.

HÄUSSERMANN, U.; PIEPHO, H.-E. Aufgabenhandbuch Deutsch als Fremdsprache; Abriss einer Aufgaben- und Übungstypologie. Munique: iudicium, 1996.

HELBIG, G. "Wieviel Grammatik braucht der Mensch?" In: HARDEN, T. (Org.) Wieviel Grammatik braucht der Mensch? Munique: iudicium, 1993. p. 19-29.

HELBIG, G.; BUSCHA, J. Deutsche Grammatik; ein Handbuch für den Ausländerunterricht. Berlin et al.: Langenscheidt, 1988.

HILPERT, S.; KALENDER, S.; KERNER, M. Schritte International 5; Kursbuch + Arbeitsbuch Niveau B1/1. Ismaning: Hueber, 2011.

JOHNSON, M. A philosophy of second language acquisition. London/New Haven: Yale University Press, 2004.

JOVANOVIC, A. Ensino de línguas e o papel da gramática. Revista da Faculdade de Educação, 12 (1/2), jan./dez. 1986. p. 145-156.

Língua materna vs. língua estrangeira: uma relação fundamental (porém menosprezada) no ensino-aprendizagem de línguas. Revista da Faculdade de Educação, 18 (2), jul./dez. 1992. p. 174-184.

JUNG, L."Fremdsprachenunterricht ohne Grammatik? Nein, danke!" In: HARDEN, T.; CLÍONA, C. (Orgs.) Wieviel Grammatik braucht der Mensch? Munique: iudicium, 1993. p. 65-90.

KALENDER, S.; KLIMASZYK, P. Schritte International 5; Lehrerhandbuch. Ismaning: Hueber, 2011.

KAPLAN, R. M.; BRESNAN, J. "Lexical-functional grammar; a formal system for grammatical representation". In: BRESNAN, J. (Org.). The mental representation of grammatical relations. Cambridge: MIT Press, 1982. p. 173-281. 
KENEDY, E. Análise de corpus, a intuição do linguista e metodologia experimental na pesquisa sobre as orações relativas do PB e do PE. Linguística, v. 4, 2009. p. 30-51.

KLEIN, W. Second language acquisition. Cambridge: Cambridge University Press, 1984.

KLEPPIN, K. Fehler und Fehlerkorrektur. Berlin et al.: Langenscheidt, 1998.

"Formen und Funktionen von Fehleranalyse, -korrektur und -therapie". In: GÖTZE, L. et al. Handbuch Deutsch als Fremdsprache, vol. II. Berlin/New York: De Gruyter, 2000. p. 986-993.

KOCH, I. G. V. Introdução à linguística textual. São Paulo: Martins Fontes, 2011.

KÖNIG, M.; FUNK, H.; NEUNER, G. Grammatik lehren und lernen. Berlin et al.: Langenscheidt, 1996.

KRASHEN, S. D. Principles and practice in second language acquisition. Oxford: Pergamon, 1982.

Second language acquisition and second language learning. Oxford: Pergamon, 1981.

KRENN, W. "Alles ist Grammatik. Ein Plädoyer für die Erweiterung des Grammatikbegriffs in der Didaktik Deutsch als Fremdsprache". In: PORTMANNTSELIKAS et al. (Orgs.) Grammatik und Sprachaufmerksamkeit. Innsbruck/Viena/Munique/Bozano: StudienVerlag, 2001.

KUMARAVADIVELU, B. Understanding language teaching; from method to postmethod. Mahwah: Lawrence Erlbaum Associates, 2006.

TESOL methods: changing tasks; challenging trends. TESOL Quarterly, v. 40, n. 1, 2006a. p. 59-81.

LEÃO, D. M. M. Paradigmas contemporâneos de educação: escola tradicional e escola construtivista. Cadernos de Pesquisa, n 107, julho/1999. p. 187-206.

LEFFA, V. J. "Metodologia do ensino de línguas". In: BOHN, H.I.; VANDRESEN, P. (Orgs.) Tópicos de linguística aplicada; o ensino de línguas estrangeiras. Florianópolis: Editora da UFSC, 1988. p. 211-236.

LENNEBERG, E. H. Biological foundations of language. New York: Wiley, 1967.

LEVELT, W. J. M. Speaking; from intention to articulation. Cambridge: MIT Press, 1989.

LIBERALI, F. C. O papel do coordenador no processo reflexivo do professor. Dissertação (Mestrado em Linguística Aplicada e Estudos da Linguagem). São Paulo: PUC-SP, 1994. 
McLAUGHLIN, B. "Algunas consideraciones metodológicas sobre el modelo del monitor”. In: LICERAS, J.M. (ed.) La adquisición de las lenguas extranjeras. Madrid: Visor, 1978. p. 153-176.

. Restructuring. Applied Linguistics 11, 1990. p. 113-128.

. Second language acquisition in childhood. New Jersey, Hillsdale, 1978a.

Theories of second language learning. London: Edward Arnold, 1987.

MARCINIUK, R. M. B. A teoria da processabilidade e a aquisição de L2. Analecta, v. 8, no 2, 2007. p. 11-27.

McKAY, S. L. Researching second language classrooms. Mahwah: Laurence Earlbaum, 2006.

MELO, L. E. "Principais teorias/abordagens da aquisição de linguagem". In:

(Org.). Tópicos de linguística aplicada. São Paulo: Humanitas, 2005. p. 25-53.

MESQUITA, A. A. F. Crenças e práticas de avaliação no processo interativo e na mediação de um par no tandem à distância; um estudo de caso. Dissertação (Mestrado em Estudos Linguísticos). São José do Rio Preto: UNESP, 2008.

MING, A. La ubicación de la gramática (explícita) en el seno de los métodos y enfoques de enseñanza de lenguas extranjeras: ¿al norte, en el centro o en las afueras? Onomázein, v. 25. Santiago: PUC de Chile, 2012. p. 107-124.

MITCHEL, R. \& F. MYLES. Second language learning theories. London: Hodder Education, 2004.

MONTENEGRO, P. C. F.; OLIVEIRA, A. A. O mito do falante nativo e a construção de identidade de futuros professores de língua inglesa como língua estrangeira. Atas do XI Congresso Internacional da ABECAN: 20 anos de interfaces Brasil-Canadá. 2011, p. 1-5.

MORESI, E. Metodologia da pesquisa. Brasília: UCB, 2003.

MULTHAUP, U. "Grammatikunterricht aus psycholinguistischer und informationsverarbeitender Sicht”. In: BÖRNER, W.; VOGEL, K. (Orgs.) Grammatik und Fremdsprachenerwerb; kognitive, psycholinguistische und erwerbstheoretische Perspektiven. Tübingen: Narr, 2002. p. 71-97.

NASCIMENTO, P. M. P. Cursos de língua estrangeira para leitura; teoria e prática, com exemplos para o alemão. Dissertação (Mestrado em Língua e Literatura Alemã). São Paulo: FFLCH-USP, 2007.

NEUNER, G.; HUNFELD, H. Methoden des fremdsprachlichen Deutschunterrichts; eine Einführung. Berlim: Langenscheidt, 1993. 
NEUNER, G.; KRÜGER, M.; GREWER, U. Übungstypologie zum kommunikativen Deutschunterricht. Berlin et al.: Langenscheidt, 1981.

NEVES, M. H. M. A gramática; história, teoria e análise, ensino. São Paulo: Editora UNESP, 2001.

NICKEL, H. "Scientific Grammar (SG) vs. Pedagogical Grammar (PG)". In: HARDEN, T. (Org.) Wieviel Grammatik braucht der Mensch? Munique: iudicium, 1993. p. 47-55.

O'MALLEY, J.; CHAMOT, A. Learning strategies in second language acquisition. Cambridge: Cambridge University Press, 1990.

PEIRCE, C. S. Abdução, dedução e indução. In: Semiótica. $4^{\mathrm{a}}$ ed. São Paulo: Perspectiva, 2010. p. 32-34.

PERCEGONA, M. S. A fossilização no processo de aquisição de segunda língua. Dissertação (Mestrado em Letras). Curitiba: UFPR, 2005.

PETERFALVI, J. M. Introdução à psicolinguística. São Paulo, Cultrix: 1970.

PIAGET, J. Biologia e conhecimento. Petrópolis: Vozes, 1996.

PICA, T. Tradition and transition in English language teaching methodology. System, v. 28, $\mathrm{n}^{\circ} 1$, mar. 2000. p. 1-18.

PIENEMANN, M. Language processing and second language development; Processability Theory. Amsterdam \& Philadelphia: John Benjamins Publishing Company, 1998.

PIENEMANN, M. "An introduction to processability theory". In: (Org.). Crosslinguistic aspects of processability theory. Amsterdam/ Philadelphia: John Benjamins, B. V., 2003. p. 1-60.

PONCIANO, I. Questionando o uso do livro didático de língua estrangeira em sala de aula. Dissertação (Mestrado em Letras). Rio de Janeiro: PUC-Rio, 2008.

PRABHU, N. S. Second language pedagogy. Oxford: Oxford University Press, 1987. 176. There is no best method - why? TESOL Quarterly, v. 24, n² 2, 1990. p. 161-

PRADO, L. A.; MING, A. A gramática em exclusivo: por que e para quê? Um estudo de crenças e expectativas discentes. Projekt (Curitiba), v. 49, 2011. p. 30-34.

PUPP SPINASSÉ, K. Os conceitos língua materna, segunda língua e língua estrangeira e os falantes de línguas alóctones minoritárias no sul do Brasil. Contingentia, vol. 1, 2006. p. 1-10. 
QUITES, A. P. O emprego das declinações por alunos de alemão como língua estrangeira em Santa Catarina. Dissertação (Mestrado em Linguística). Florianópolis: UFSC, 1997.

RAMPILLON, U. Aufgabentypologie zum autonomen Lernen. Ismaning: Hueber, 2000.

RASTER, P. "Der Ursprung der Grammatik in Indien und Europa und die Achsenzeit der Weltgeschichte". In: YOUSEFI, H. R.; FISCHER, K. (Orgs.). Interkulturalität: Diskussionsfelder eines umfassenden Begriffs. Nordhausen: Bautz, 2010. p. 287-309.

RAUPACH, M. "'Explizit/implizit' in psycholinguistischen Beschreibungen - eine unendliche Geschichte?" In: BÖRNER, W.; VOGEL, K. Grammatik und Fremdsprachenerwerb; Kognitive, psycholinguistische und erwerbstheoretische Perspektiven. Tübingen: Gunter Narr, 2002. p. 99-117.

RAUTH, H.W. Sequência de desenvolvimento de aquisição de português língua estrangeira. Dissertação (Mestrado em Letras), Curitiba: UFPR, 2003.

RICHARDS, J. The role of textbooks on a language program. Disponível em: <http://www.professorjackrichards.com/wp-content/uploads/role-of-textbooks.pdf>. Último acesso em: 21 abr. 2014. s/d. p. 1-6.

ROSA, A. A. C.; BASSO, E. A. Estratégias de aprendizagem em língua estrangeira: investigando a prática da sala de aula. Revista NUPEM, v. 2, n 3, ago/dez 2010. p. 89100.

ROTHWEILER, M. Der Erwerb von Nebensätzen im Deutschen; eine Pilotstudie. Tübingen: Niemeyer, 1993.

SANTAELLA, L. Comunicação e pesquisa; projetos para mestrado e doutorado. São Paulo: Hacker Editores, 2001.

SANTOS, A. M. Análise de erros gramaticais na produção escrita de aprendizes brasileiros de espanhol; o papel da língua materna. Dissertação (Mestrado em Letras). Pelotas: Universidade Católica de Pelotas, 2006.

SANTOS, E. M. Gramatica e língua estrangeira numa escola de ensino médio; o que se ensina. Dissertação (Mestrado em Linguística Aplicada). Campinas: IEL/Unicamp, 2001.

SAUSSURE, F. Cours de linguistique générale. Paris: Payot, 1970 [1916].

SAVILLE-TROIKE, M. Introducing second language acquisition. Cambridge: Cambridge University Press, 2006.

SCHÄFER, A. C. A gramática alemã sob a perspectiva de seus aprendizes: crenças discentes e estratégias de aprendizagem. Pandaemonium Germanicum, v. 16, $\mathrm{n}^{\circ} 21$, 2013. p. 190-213.

SCHÜTZ, R. Assimilação natural x ensino formal. English Made in Brazil. Disponível 
em: <http://www.sk.com.br/sk-laxll.html>. Último acesso em: 01 dez. 2013.

SELINKER, L. Interlanguage. International Review of Applied Linguistics, v. 10, 1972. p. 209-231. Rediscovering interlanguage. Londres: Longman, 1992.

SEVERINO, A. J. Metodologia do trabalho científico. $21^{\text {a }}$ ed. rev. amp. São Paulo: Cortez, 2000.

SIGNORINI, I. "Do residual ao múltiplo e ao complexo: o objeto da pesquisa em linguística aplicada". In: SIGNORINI, I.; CAVALCANTI, M. Linguística aplicada e transdisciplinaridade. Campinas: Mercado de Letras, 1998.

SILVA, C. A. Coesão e coerência na produção escrita na língua estrangeira; uma investigação da influência da língua materna. Dissertação (Mestrado em Linguística Aplicada). Brasília: UnB, 2006.

SILVA, G. A. A era pós-método; o professor como um intelectual. Linguagens \& Cidadania, n. 12, 12/04, Santa Maria: UFSM, 2008. Disponível em < http://coral.ufsm.br/lec/02_04/Gisvaldo.htm>, último acesso em 25 nov. 2013.

SILVA, S. P. Livro didático de língua estrangeira: (in)dispensável? E-scrita. Nilópolis, v.3, n 1 A , Jan. - Abr. 2012. p. 179-187.

SINCLAIR, J.M.; RENOUF, A. "A lexical syllabus for language learning". In: CARTER, R.A.; McCARTHY, M. (Orgs.). Vocabulary and language learning. Harlow: Longman, 1988. pp. 140-160.

SOARES, D. A. A escrita na escola: teoria e prática. Cadernos do XVII Congresso Nacional de Linguística e Filologia - Minicursos e Oficinas, v. XVII, $\mathrm{n}^{\circ}$ 03. Rio de Janeiro: CiFEFiL, 2013. p. 19-32.

SOBROZA, L. S. Aquisição x aprendizagem da língua estrangeira. Linguagens \& Cidadania, v. 10, $\mathrm{n}^{\circ} 1,2008$. p. 1-20.

SPANNHAKE, B.; BOGACZ-GROSS, A. "Grammatik im DaZ-Unterricht". In: KAUFMANN, S. et al. (Orgs.). Fortbildung für Kursleitende Deutsch als Zweitsprache. Band 2. Didaktik. Methodik. Ismaning: Hueber Verlag, 2008.

SPIEKERMANN, H. "Variation in der deutschen Sprache". In: KRUMM, H.-J. et al. (Orgs.). Deutsch als Fremd- und Zweitsprache; ein internationales Handbuch, vol 1. Berlin/New York: De Gruyter, 2010. p. 343-359.

SPOLSKY, B.; HULT, F. M. The handbook of educational linguistics. Oxford: Blackwell Publishing, 2008.

SQUIRE, L. R.; ZOLA-MORGAN, S. The medial temporal lobe system. Science, n. 253, 1991.p. 1380-1386. 
STANICH, K. Análise de erros em português e alemão como línguas estrangeiras. Pesquisa de Iniciação Científica (Processo FAPESP 99/03932-2). São Paulo: FFLCHUSP, 2000 (manuscrito não publicado).

Aspectos do processamento cognitivo relacionado à produção em língua estrangeira e aprendizagem de falantes não-nativos de alemão; hipótese explicativa. Tese (Doutorado em Língua e Literatura Alemã). São Paulo: USP, 2008.

; MEIRELES, S. Processamento cognitivo relacionado à produção em língua estrangeira e aprendizagem de falantes não-nativos de alemão. Pandaemonium Germanicum, n 14, vol. 2, 2009. p. 179-205.

TOWELL, R.; HAWKINS, R. Approaches to second language acquisition. Clevedon: Multilingual Matters, 1994.

UPHOFF, D. Leistungsmessung, Fehlerkorrektur und das Bild des Lehrers im Diskurs der Fernstudieneinheiten Deutsch als Fremdsprache. Anais do $8^{\circ}$ Congresso Brasileiro de Professores de Alemão, ABRAPA, 2011. p. 1-11.

O caráter institucional do uso do livro didático no ensino de língua estrangeira. Intercâmbio, v. XVII, 2008. p. 131-141.

O poder do livro didático e a posição do professor no ensino de alemão como língua estrangeira. Tese (Doutorado em Linguística Aplicada). Campinas: IEL/Unicamp, 2009.

A área de alemão como língua estrangeira: desenvolvimento histórico e perspectivas atuais. Pandaemonium Germanicum, v. 16, n 22, 2013. p. 219-241.

VENTURI, M. A. Tópicos de aquisição e ensino de línguas estrangeiras. São Paulo: Humanitas, 2008.

VITULLO, M. E. O papel da gramática no ensino e na aprendizagem de francês língua estrangeira; importância, função e delimitação. Tese (Doutorado em Estudos Linguísticos, Literários e Tradutológicos em Francês). São Paulo: FFLCH/USP, 2011.

WILKINS, D. A. Notional Syllabus; a taxonomy and its relevance to foreign language curriculum development. London: Oxford University Press, 1978. 
APÊNDICE 
Apêndice 1a: Lista das escolas de alemão de São Paulo (cursos livres para adultos) e LDs adotados para cursos regulares dos níveis $\mathrm{A} 1$ a $\mathrm{B} 1 \mathrm{do} \mathrm{QECR}^{217}$

\begin{tabular}{|c|c|c|}
\hline ESCOLA & LOCALIDADE & LD ADOTADO - $1^{\circ}$ sem. 2014 \\
\hline AKTION IDIOMAS & São Paulo & Themen aktuell \\
\hline ALE IDIOMAS & Marília & \\
\hline ALLE IDIOMAS & São Paulo & Schritte International \\
\hline ALL FAMILY & São Paulo & Berliner Platz \\
\hline ALIANÇA CULTURAL & Santo André & Themen aktuell \\
\hline ALIANÇAIDIOMAS & São Carlos & studio $d$ \\
\hline APG-ITA & São José dos Campos & studio d \\
\hline ÁPICE & Mogi Guaçu & \\
\hline ASAP & Sorocaba & Schritte International \\
\hline BAHNHOF & $\begin{array}{l}\text { São Bernardo } \\
\text { do Campo }\end{array}$ & Schritte International \\
\hline BAUSTEINE & São Paulo & $\begin{array}{l}\text { Schritte International } \\
\text { studio d }\end{array}$ \\
\hline BERLIN.DE & São Carlos & Schritte International \\
\hline BEST SCHOOL & Araraquara & \\
\hline BILDUNGSHAUS & Jundiaí & \\
\hline
\end{tabular}

${ }^{217}$ Foi utilizada a lista de escolas parceiras do Instituto Goethe no estado de São Paulo, disponível em 〈http://www.goethe.de/ins/br/lp/prj/fal/stu/sao/ptindex.htm>, acessos em: 25 nov. 2013 e 26 mai. 2014 (diretório online "Falemão!"). 


\begin{tabular}{|c|c|c|}
\hline CAVC IDIOMAS & São Paulo & Schritte International \\
\hline CCEURO & São Paulo & studio 21 \\
\hline CIK - KOELLE & Rio Claro & $\begin{array}{l}\text { Tangram aktuell } 1 \\
\text { studio } d A 2 / B 1\end{array}$ \\
\hline $\begin{array}{l}\text { CULTURA AMERICANA } \\
\text { CAMBRIDGE }\end{array}$ & Araraquara & Themen aktuell \\
\hline CULTURAL CENTER & Mogi das Cruzes & Themen aktuell \\
\hline CEL-LEP & $\begin{array}{l}\text { São Paulo } \\
\text { Piracicaba }\end{array}$ & Berliner Platz \\
\hline DerDieDas & São Carlos & Schritte International \\
\hline $\begin{array}{l}\text { DEUTSCHES } \\
\text { KULTURZENTRUM } \\
\end{array}$ & Campinas & $\begin{array}{l}\text { Berliner Platz / studio d / } \\
\text { Themen aktuell }\end{array}$ \\
\hline DEUTSCHPUR & Araraquara & $\begin{array}{l}\text { Menschen } \\
\text { DaF-Kompakt }\end{array}$ \\
\hline DIALÍNGUAS & São José dos Campos & studio d \\
\hline DIALOG & São Paulo & $\begin{array}{l}\text { Cada professor decide qual usar; } \\
\text { todos utilizam algum }\end{array}$ \\
\hline EXPRESSÃO & Campinas & Themen aktuell \\
\hline FALE LÍNGUA！ & São Paulo & $\begin{array}{l}\text { Schritte International } \\
\text { studio } 21\end{array}$ \\
\hline HAVAD & Campinas & studio $d$ \\
\hline $\begin{array}{l}\text { HD IDIOMAS } \\
\text { (LUMINA PRIME) }\end{array}$ & São Paulo & Themen aktuell \\
\hline ICHIBAN & $\begin{array}{l}\text { Guaratinguetá } \\
\text { São José dos Campos }\end{array}$ & Menschen \\
\hline IEBA & Ribeirão Preto & studio d \\
\hline $\begin{array}{l}\text { IGREJA EVANGÉLICA } \\
\text { LUTERANA }\end{array}$ & Santo André & Tangram aktuell \\
\hline
\end{tabular}




\begin{tabular}{|c|c|c|}
\hline IN BERLIN & Guaratinguetá & studio d \\
\hline INSTITUTO STEIGER & São Paulo & \\
\hline INTERLÍNGUA & Santo André & Schritte International \\
\hline $\begin{array}{l}\text { INSTITUTO ANGLO- } \\
\text { GERMÂNICO }\end{array}$ & Santos & studio $d$ \\
\hline INST. BERLINER & São Paulo & Schritte International \\
\hline INST. GOETHE & São Paulo & studio d \\
\hline KREATIV & $\begin{array}{l}\text { Campinas } \\
\text { Valinhos }\end{array}$ & Optimal \\
\hline LANGUAGE COMPANY & São Paulo & - \\
\hline LESSA IDIOMAS & São Bernardo do Campo & Themen aktuell \\
\hline LIFE IDIOMAS & São Bernardo do Campo & Schritte International \\
\hline LINGUAE & São Paulo & studio $d$ \\
\hline LINGUISTIK & São Paulo & studio d \\
\hline LOGISCH LANGUAGE & Valinhos & Optimal \\
\hline LOTUS & São Paulo & Themen aktuell \\
\hline MASTER LANGUAGES & São Paulo & Berliner Platz \\
\hline MULTI CULTURA & Araçatuba & \\
\hline MUTH TALENT & Nova Odessa & studio $d$ \\
\hline OFICINA DE IDIOMAS & São Paulo & Tangram aktuell \\
\hline
\end{tabular}




\begin{tabular}{|c|c|c|}
\hline POLIGLOTA & São Paulo & Berliner Platz \\
\hline SAL DA TERRA & São Paulo & Schritte International \\
\hline SELF IDIOMAS & Piracicaba & studio $d$ \\
\hline SET IDIOMAS & São Paulo & Menschen \\
\hline SKYWARDS IDIOMAS & São Paulo & studio d \\
\hline STUDIO DE IDIOMAS & Campo Limpo Paulista & $\begin{array}{l}\text { Wir neu (LD para jovens usado com } \\
\text { adultos na escola) }\end{array}$ \\
\hline TEUTO IDIOMAS & São Paulo & Schritte International \\
\hline TÜBINGEN & Jundiaí & Schritte International \\
\hline WORKSHOP & Franca & Schritte International \\
\hline WUNDERWELT A & $\begin{array}{l}\text { Atibaia } \\
\text { São Paulo }\end{array}$ & Schritte International \\
\hline YESKY IDIOMAS & São Caetano do Sul & Linha Alemão (material próprio) \\
\hline YUCCA & Sorocaba & Berliner Platz \\
\hline ZWEI & São Carlos & studio d \\
\hline
\end{tabular}

\section{Observações sobre o apêndice 1a:}

1. Todas as informações contidas neste apêndice foram obtidas junto à coordenação pedagógica ou à diretoria de cada escola, por telefone ou e-mail. A indicação de dois títulos significa que a escola alterna seu uso a depender do público ou que são empregados em diferentes cursos/estágios. 
2. O traço significa que, nas tentativas realizadas no final do $2^{\circ}$ semestre de $2013 \mathrm{e}$ também no final do $1^{\circ}$ semestre de 2014 , não se obteve resposta por telefone nem por e-mail (foram feitas sempre as duas tentativas), considerados os dados fornecidos pelo Goethe-Institut São Paulo no site "Falemão!" para o estado de São Paulo, sendo que, em alguns casos, o número de telefone não é válido e/ou o e-mail retornou sem alcançar um destinatário. Foram excluídas da lista as escolas contidas no site Falemão! <http://www.goethe.de/ins/br/lp/prj/fal/erw/sao/ptindex.htm> do Goethe-Institut São Paulo que, entretanto, não existem ou funcionam mais (CCBEU e D'Kurs).

3. Somente foram incluídas na lista escolas que oferecem "cursos livres" de alemão para adultos, à semelhança dos cursos junto aos quais se deu a coleta de dados. Excluíram-se, assim, as escolas alemãs (ensino fundamental e médio) de São Paulo, bem como os cursos de bacharelado em Letras/Alemão, dada a sua natureza e objetivos diferenciados.

4. Com 16 escolas adotando Schritte International e 17 escolas adotando studio d (ou sua versão mais atual, studio 21), conforme nos mostra a tabela acima, podese afirmar que esses dois LDs são os mais empregados pelas escolas de idiomas que oferecem cursos livres de ALE para adultos no estado de São Paulo. 
Apêndice 1b: Lista dos cursos livres de alemão de São Paulo para adultos oferecidos pelas universidades públicas paulistas ao público geral (observar restrições) e LDs adotados nesses cursos dos níveis A1 a B1 do QECR

\begin{tabular}{|l|l|l|}
\hline \multicolumn{1}{|c|}{ CURSO E IES } & LD ADOTADO 2014 & $\begin{array}{l}\text { ABERTO AO } \\
\text { PÚBLICO } \\
\text { EXTERNO }\end{array}$ \\
\hline $\begin{array}{l}\text { ALEMÃO NO CAMPUS } \\
\text { (USP) }\end{array}$ & Menschen / studio 21 & Sim \\
\hline $\begin{array}{l}\text { CENTRO DE E. DE } \\
\text { LÍNGUAS (Unicamp) }\end{array}$ & Blaue Blume & Em partes \\
\hline $\begin{array}{l}\text { CENTRO DE LÍNGUAS } \\
\text { (UNESP Assis) }\end{array}$ & $\begin{array}{l}\text { apostilas de elaboração } \\
\text { própria }\end{array}$ & Em partes \\
\hline $\begin{array}{l}\text { CENTRO DE LÍNGUAS } \\
\text { (UNESP Araraquara) }\end{array}$ & \multicolumn{1}{|c}{} & Em partes \\
\hline
\end{tabular}

1. Como informa o site do Centro de Línguas e Desenvolvimento de Professores da UNESP de Assis, "o Centro de Línguas Estrangeiras e Desenvolvimento de Professores da UNESP-Assis oferece cursos bimestrais de inglês, espanhol, francês, italiano, alemão, japonês, chinês e português - língua estrangeira, nos níveis Básico 1 e 2, Intermediário 1 e 2 e Avançado 1 e 2, a alunos, professores e funcionários da Faculdade de Ciências e Letras de Assis e a alunos das escolas públicas do município. Esses seis níveis estão em sintonia com o Quadro Europeu Comum de Referência para as Línguas", como informado em http://unespassiscentrodelinguas.weebly.com/cursos-de-liacutenguasestrangeiras.html, acesso em: 25 nov. 2013.

2. Assim como consta no site do Centro de Ensino de Línguas (CEL) da Unicamp, "o CEL tem como segunda prioridade a oferta de cursos de extensão para a comunidade em geral”. Desse modo, além dos cursos de línguas (incluído o alemão) oferecidos à comunidade universitária (como disciplinas de graduação), eventualmente abrem-se cursos oferecidos a interessados externos. No segundo semestre de 2013, não houve cursos de extensão em alemão. Informações 
disponíveis

em

$<$

http://www.cel.unicamp.br/index.php?option=com_content\&view=article\&id=8 6\&Itemid=492 >, acesso em: 25 nov. 2013. 


\section{Apêndice 2a: Entrevista com o professor do Grupo A (Schritte International)}

Pergunta: Você poderia me contar como se desenvolveu a aula baseada na proposta do LD [Schritte International 5] das págs. 24, 25 e 29?

Resposta: Eu acho um tema difícil de explicar. Esse é um tema da gramática que eu tento de alguma maneira pensar como é que pode ser diferente. Então, se a gente conversa alguma coisa sobre o fim de semana, eu procuro tirar daquela conversa que a gente está falando, se se falou de comida, de amigos, eu pergunto "então ta, pensem aí em algum amigo de vocês, e caracteriza alguma coisa desse amigo", então o aluno faz alguma frase caracterizando o amigo Fulano, enfim, deixa eu lembrar... Aí você vai, por exemplo, conversar a dois, depois de um exemplo em Plenum [plenário], “quais são os amigos em que você pensou, quem é, o Pedro?", eu tento levar o aluno a precisar usar a frase relativa, “o Pedro é aquele que alguma coisa”. Isso não é fácil, tento ir por aí, digo "eu acho que sei o que você está querendo dizer", ponho o exemplo com a oração relativa na lousa e, depois de dado o exemplo na lousa, vamos para o livro, para o que o livro mostra. O livro faz os alunos completarem frases com os pronomes relativos a partir de uma correlação de gênero com o elemento de referência da oração anterior, o aluno vai lá completar o pronome relativo ainda sem saber o que que é, mas tudo leva ele a deduzir que onde é o masculino ele vai usar o "der", o "das" para o neutro e o "die" para o feminino. Mas dificilmente ele assimila realmente, naquele momento, isso como o pronome relativo, e que deve ser assim, porque a tendência é até o préavançado, como a gente tem lá na escola, a tendência é usar o "das", eles querem sempre usar o "das" e a gente tem que mostrar e explicar que não é assim, e apresentar os pronomes relativos, sempre que possível. Depende da dinâmica e das capacidades dos grupos, porque os grupos são diferentes. Tem grupos que permitem que a gente coloque um desafio, tem aluno que consegue chegar a realizar sem a gente ter que explicar, mas sempre tem alguns que, em algum momento, a gente precisa mastigar bastante o tema e fazer bastante exercícios. Os exercícios do livro eu acho que não são suficientes e aí procuro trazer com outros temas, aproveitar algum tema de conversa, retomar o tema, ir devagar e ir colocando com preposição no passo seguinte. Um problema sério é que o pessoal fala muito errado o português, há muito problema para construir frase relativa em português, eles dizem "o amigo que o pai morreu", "o amigo que eu fui viajar junto", e geralmente assim, é uma menor parte das pessoas que fala 
isso corretamente e assim consegue aprender com mais facilidade. Eu acho que a maioria dos meus alunos, na hora de escrever em português, faria certo, sim. São estudantes da USP, têm um nível muito bom no geral, mas sempre tem uns com certeza que escrevem mal, a gente percebe no próprio texto em alemão que não percebem qual é o sujeito, não tem concordância, "o amigo que eu trabalho" é uma estrutura que está por trás e é preciso retomar a norma culta do português para fazer o contraste com o alemão, porque tirando a declinação o princípio é o mesmo.

Pergunta: Em que tipologia de exercícios, ou tipologias, você baseia a condução da sua aula?

Resposta: Eu sou uma pessoa muito intuitiva, tenho uma coisa muito boa, de talento, no tetê-à-tête com os alunos, mas o próprio Schritte é muito baseado em princípio numa graduação, que eu nem sempre concordo muito, uma graduação que vai do enunciado em preto, com tudo dado para o aluno, são os exercícios mais simples, depois o azul e cinza, exercícios em que o aluno vai sendo mais independente, no caso das orações relativas o aluno já não coloca mais só o pronome, ele faz a frase, e depois eu peço sempre um texto, eventualmente, peço para aplicarem no caso as relativas ou o tema que for o tema da vez num texto, ou seja, de menos para mais independência. Esse nível em que aparece frases relativas, a gente trabalha um livro inteiro por módulo, os dois primeiros livros são divididos em três módulos de curso e depois é um livro por módulo, o que é bom por um lado, porque motiva o aluno, que vê que está indo pra frente mesmo, mas é muita coisa e eu confesso que às vezes não dá pra fazer todas as fases não, a gente vai retomando mais pra frente, dá lição de casa, não dá pra em todo tema fazer uma sequência de quatro, cinco exercícios, às vezes eu dou três, sempre do mais dado pro que exige mais liberdade. Mas enfim, você falou tipologia de exercício, eu diria progressão, enfim, não foi com a coordenação da escola que eu cheguei nessa progressão, foi em seminários da APPA e no Goethe.

Pergunta: Você trabalha em meio institucional mediante a adoção de um livro didático pré-selecionado pela instituição. Na sua visão, de que formas você pode determinar o uso que faz do material e em que pontos, se for o caso, sente que há limitações nesse sentido? 
Resposta: Eu na verdade posso fazer como me der na telha, mas assim, o curso é dividido em duas provas, são x lições para a primeira prova e x para a segunda, mas a ordem em que eu faço as coisas dentro dessas determinações é livre, posso substituir coisas do livro por material de fora. É sempre interessante trazer outra coisa quando der tempo, mas sobretudo em frase relativa não é difícil encontrar, mentira, é difícil sim, mas achar músicas com frase relativa, nesse sentido tenho, sim, bastante liberdade, mas não posso pular lições e é claro que jamais pular a gramática da lição, nunca realmente, não pode, não dá e eu acho que levaria bronca [risos].

Pergunta: Com relação ao modelo linguístico de orações relativas apresentado aos alunos pelo livro, você operou alguma modificação, exclusão ou acréscimo?

Resposta: Ah, não, eu não mostro tudo o que existe, não, porque tem coisas às vezes que eu falo até mais por curiosidade para que não se assustem, agora não lembro o quê, mas posso falar como curiosidade para que não se espantem, porque é uma língua dinâmica, na fala aparece de tudo, nos dialetos, mas no geral eu ensino mesmo o que é correto e o que está no livro, a não ser que eu tenha vivenciado muito, que faça verdadeiramente parte da minha experiência e aí eu faço questão de ter essa troca com eles, mas senão não, e nos casos das frases relativas, apenas os pronomes relativos que estão no livro.

Pergunta: Quanto às funções das orações relativas no discurso, como você introduz essa questão de forma semântica e pragmático-funcional?

Resposta: Bom, naquele início que eu falo, como vocês caracterizam os amigos de vocês, como vocês caracterizam esses amigos, procuro colocar uma situação, ou falar de um filme, de um livro, de determinados atores ou a cidade em que você esteve, enfim, coisas da vida que precisamos explicar, especificar, deixo claro que é para isso, mas na comparação com o português fica muito fácil. É fácil assim chegar na situação em que eles precisem da frase relativa para se expressar e estou convencida de que comparar com o português resolve essa questão, porque você falou em função e a função é a mesma, ou as funções são as mesmas, explicar, especificar. 
Pergunta: Você combina atividades comunicativas a atividades baseadas em preceitos de outros métodos e abordagens?

Resposta: A parte de traduzir, por exemplo, eventualmente tem o livro que uso no préavançado, o Ziel, ele traz alguns exercícios e propõe a tradução para a língua materna. Nem sempre acho necessário, mas quando percebo que é necessário, por exemplo incluo a tradução, deixo claro até que às vezes basta traduzir o que o aluno disse para que ele se toque do erro dele, então acho que a tradução, usar a tradução, é o melhor exemplo. Raramente repetir várias vezes alguma coisa muito raramente, essa coisa de drills, só se eu percebo que ele não sentiu aquilo que está dizendo. Tem aluno que esquece de se dedicar à fala completa. Uma vez que ele comunica, fica preguiçoso, não está se tocando, então tem que pedir "fala isso, repete isso", eventualmente, até para gravar alguma estrutura, essa coisa de verbo lá no fim, mesmo a conjugação, mas uma coisa que acontece espontaneamente e não planejadamente. Planejadamente minha aula é comunicativa, como o livro é comunicativo e a proposta lá da escola.

Pergunta: Como você definiria, de forma espontânea, suas concepções de ensino, didática, práticas docentes, Lehrerverhalten [comportamento do professor em sala de aula], e as da instituição em que você trabalha?

Resposta: Prática de ensino, tudo isso junto, as minhas e as da escola, a escola na verdade interfere muito pouco, mas a coordenadora atual participa muito pouco, temos pouquíssimas reuniões pedagógicas, mas a escola é comunicativa, claro, qual não é? Pela minha experiência, independentemente da proposta da escola, eu mesma gosto de gramática, da língua, de perceber as peculiaridades da língua, então se o aluno tem esse perfil ele aprende mais comigo, alunos que gostam de aprender como criança não aprenderiam bem comigo. Mas eu acho que o aluno tem que usar a língua, ver como é útil, que ela serve para alguma coisa, para fazer coisas com ela na vida, fazer atividades o tempo todo porque senão não tem quem aguente uma aula de 3 horas, é ativar, ativar, ativar, participar, usar, ser gente dentro da sala de aula, usar a língua na realidade pessoal, buscar sempre um link com a experiência pessoal de cada um.

Pergunta: Qual é a sua formação acadêmica para ser professor de alemão, e qual é a sua experiência profissional?Você já viveu em um país de língua alemã? 
Resposta: Olha, engraçado você me perguntar isso, porque eu já tinha perdido as contas, mas comecei a dar aula na raça há 19 anos e sei te falar isso de cor porque tivemos que calcular esse tempo de experiência num seminário que eu participei esses dias, para professores. Estou lá [na instituição em que trabalha atualmente] desde 2005, mais os particulares, que eu sempre tenho. Bom, que mais era, formação, eu fiz Letras Alemão na [universidade federal brasileira], fiz DLA, as duas partes, quero dizer, os dois cursos. A parte na Alemanha também, e fiz vários seminários na Alemanha, eu sempre vou, agora em dezembro estive em Salzburg e Wien [Viena], encontrei ex-aluno na rua, acredita? Mas nunca morei lá de verdade, sempre vou nas férias, dois, três meses quando dá.

Pergunta: O que você poderia me contar sobre o trabalho com essa turma em particular?

Resposta: Era uma turma ruim, vou te dizer. Tinha um que não era excelente, mas ele era um carinha razoável, inteligente, tal, no geral um perfil de alunos muito dispersos, embora sejam interessados, um paradoxo. O que acontecia muito frequentemente, não existe um tempo ideal para trabalhar todas as coisas, eles chegam nesse nível para aprender a frase relativa trazendo na verdade um acúmulo de problemas, desde a conjugação dos verbos, não lembrar que "vocês" é "ihr", trocar as coisas, os gêneros, então acontece muito de ser bem complicado na real, você quer explorar bem o assunto, esse tema das relativas e corrigir problemas bem mais básicos, e eu vi que teve ali nos seus exercícios problemas desse tipo. Mas eles são alunos de um bom nível, primeiro que o alemão já é muitas vezes a terceira língua deles, muitos deles já têm francês além do inglês, então já têm uma facilidade, uma compreensão que também ajuda, mas aí estou sendo contraditória, porque ao mesmo tempo surpreende como alunos desse nível, mestres, gente da USP, vir com as defasagens que eles vêm, no geral não têm dificuldades não, mas a gente se surpreende com coisas que seriam óbvias, mas é aquela coisa, óbvias para nós professores. Tenho uma vantagem grande comparada aos meus colegas professores de inglês, porque muita gente vai aprender inglês como primeira língua estrangeira, por obrigação, eles não têm o respaldo que meus alunos poliglotas têm. Vou ser bem direta, são inteligentes, muito inteligentes, jamais burros, mas têm uma porrada de outras coisas pra fazer, o mestrado, o estudo, não têm aquela dedicação ideal que a gente sabe, e muitas vezes é falta de oportunidade de uso, todo professor 
deveria pedir mais produção de texto, claro que depois de fixada a matéria. Tem aluno que acaba falando menos na aula, a gente não pode forçar, mas depois isso se reflete. $\mathrm{O}$ alemão é muito estranho, demora bastante para se familiarizar com a estrutura do alemão, eles se habituam, a primeira coisa que eles aprendem, que vai lá no fim da frase, além de usar os verbos separáveis, mas é o particípio, eles se habituam bastante com o particípio no fim da frase, e se habituam a colocar o particípio quando têm que colocar o infinitivo no fim da frase, e sai coisas horríveis, "ich kann nicht gekauft" [eu não posso comprado], "ich kann nicht gesprochen" [eu não posso/sei falado], mas com mais tempo de estudos seriam ótimos, tenho sorte, gente muito inteligente. Essas turmas pequenas que a gente tem fluem melhor, têm mais oportunidade para se exporem, no basicão a turma é grande, eles praticam menos e fica uma defasagem pra gente sanar.

Pergunta: Qual foi a preparação dos alunos para a aplicação dos exercícios?

Resposta: Olha, basicamente o negócio do Roman que você pediu, mas eles já sabiam, eu achei isso. Expliquei que era para um trabalho de mestrado e a reação deles foi ótima, encararam aquilo tudo como oportunidade para treinar mais.

Muito obrigado! 


\section{Apêndice 2b: Entrevista com o professor do Grupo B (studio d)}

Pergunta: Você poderia me contar como se desenvolveu a aula baseada na proposta do LD [studio d A2 Gesamtband] das págs. 184 e 185?

Resposta: Ok. Inicialmente, pedi que os alunos lessem o texto da página 184 e que, sozinhos, marcassem as palavras que não entendem. Depois, eles compararam entre eles e só quando não havia mais perguntas com relação ao vocabulário é que eu iniciei a questão 4. Nesta questão, por se tratar de frases relativas, eu pedi que os alunos procurassem no livro onde esse assunto já havia aparecido. Aí um grupo disse que achou, na lição 6, e eu perguntei em que casos os exemplos estavam. Depois que me responderam nominativo e acusativo, eu voltei para a questão 4 e pedi que alunos lessem em voz alta as frases do exemplo. Um aluno lia os dois exemplos juntos e um outro o exemplo onde as duas frases aparecem juntas. Depois que lemos todas as frases juntos, eu pedi que sozinhos nos grupos eles discutissem se conseguiam entender os exemplos. A resposta foi positiva e, então, depois eu solicitei que eles preenchessem a tabela do exercício b, e informei que estas informações são achadas nos exemplos. Depois, corrigimos im Plenum [plenário]. Meu próximo passo foi solicitar que os alunos escrevessem frases com os exemplos vistos no exercício 5. Depois, pedi que uma pessoa de cada grupo lesse uma frase. Depois dessa atividade, escrevi na lousa em alemão "Das ist die Wohnung, ..." e pedi que eles completassem com um exemplo oralmente em cada grupo. Depois ouvimos os exemplos de todos os alunos. Depois de termos ouvido todos os exemplos, pedi que fizessem o exercício número 9 do Sprachtraining, onde os alunos precisam escrever uma oração relativa com informação que já aparece no diálogo. Depois, corrigimos as frases na lousa, e aqui os alunos perceberam que há a possibilidade de frases relativas sem as preposições in e mit, que são apresentadas inicialmente.

Pergunta: Em que tipologia de exercícios, ou tipologias, você baseia a condução da sua aula?

Resposta: Seguindo a seguinte lógica: 1) o assunto é apresentado aos alunos, 2) eles precisam preencher algo que já está presente na questão, eles não precisam pensar em nada, pois a resposta já está lá; 3) depois, um exercício em que eles precisem completar 
algo que já foi previamente apresentado, como uma frase, mas já criando algo, e 4) eles precisam produzir algo escrito, como um texto de tema livre usando a estrutura. No DLA [Deutschlehrerausbildung, curso de formação de professores do Goethe-Institut São Paulo para os níveis A1 - B1 do QECR, atualmente reformulado como DLL Deutsch lehren lernen] eles falavam do A-B-C-D.

Pergunta: Na aula em que você ensinou os pronomes relativos no nominativo e acusativo, como foi a dinâmica?

Resposta: Na primeira aula, foram feitas atividades onde ficou claro para os alunos que os exemplos em questão estavam todos no nominativo. Na aula seguinte, no início houve uma rápida revisão sobre esse assunto e depois trabalhei com outros exemplos, mas, desta vez, todos no acusativo. Depois pedi que eles comparassem os exemplos da primeira e da segunda aula e então perguntei se havia alguma diferença. Todos concordaram que sim e pedi que eles explicassem qual era essa diferença. Então eles disseram que os exemplos não eram iguais, pois na segunda aula não havia exemplos de orações no nominativo, só acusativo.

Pergunta: Você trabalha em meio institucional mediante a adoção de um livro didático pré-selecionado pela instituição. Na sua visão, de que formas você pode determinar o uso que faz do material e em que pontos, se for o caso, sente que há limitações nesse sentido?

Resposta: Onde eu trabalho, tenho total autonomia para trabalhar com o livro didático. Isso quer dizer que não preciso seguir exatamente toda a sequência dos exercícios, posso pular questões que considere desnecessárias, exageradas ou confusas, posso adaptar questões à realidade sociocultural dos alunos e ainda tenho o suporte de um livro extra de exercícios. Todavia, essa liberdade tem limites. Eu não tenho permissão para, por exemplo, não seguir a cronologia das lições em sala de aula, mesmo que eu ache que a sequência seguida pelo livro não contribui para o aprendizado dos alunos, eu sou obrigado pela instituição a seguir exatamente a ordem das lições. Também não posso pular uma novidade gramatical ou coisas que vêm com o sinalzinho do GER [Quadro Europeu Comum de Referência]. O diretor sempre diz que espera de nós o uso inteligente do livro didático. Bom, eu acho que é irrelevante seguir todos os textos do 
livro, porque você pode também não se lembrar de jeito nenhum de onde o assunto aparece e dar um exemplo aleatório com uma oração relativa. Não acho que somos obrigados a seguir o livro em tudo. Mas sim, onde eu trabalho é impossível ministrar as aulas sem a utilização desse livro didático, o máximo que posso fazer é adaptar exercícios, mas exercícios que estejam no livro. Lógico que eu posso abordar o assunto dentro de uma outra temática, mas aí trata-se de uma Arbeitsblatt [folha de material extra]. Eu troco às vezes a ordem dos exercícios para fazer o A-B-C-D, às vezes com o livro já dá, mas não naquela ordem. Nem sempre.

Pergunta: Com relação ao modelo linguístico de orações relativas apresentado aos alunos pelo livro, você operou alguma modificação, exclusão ou acréscimo?

Resposta: Como o assunto orações relativas é muito vasto e pode aparecer com várias preposições, eu prefiro introduzir o assunto apenas com os exemplos que aparecem $a$ priori no livro. Eu acho que dar exercícios englobando exemplos demais pode confundir ou desestimular o interesse dos alunos pelo assunto. O máximo que eu faço é adaptar questões que eu acho não estarem muito bem feitas. Não, eu não incluo outros pronomes relativos que não esses do livro. Não nesse nível.

Pergunta: Quanto às funções das orações relativas no discurso, como você introduz essa questão de forma semântica e pragmático-funcional?

Resposta: Eu faço que os alunos percebam que a função da oração relativa é explicar o significado de um termo que apareceu na oração principal. A explicação desse termo vai ser, lógico, uma oração subordinada, e que para isso, em alemão, não podemos utilizar como em português só uma palavra. Geralmente, no português o falante em discurso livre utiliza a palavra "que". Ele precisa perceber que, em alemão, esse "que" vai depender do gênero da palavra e da função sintática que exerce na frase.

Pergunta: Você combina atividades comunicativas a atividades baseadas em preceitos de outros métodos e abordagens?

Resposta: Sim. Como eu mesmo fui aluno de alemão há algum tempo atrás, eu me lembro claramente dos exercícios que eu fiz quando eu era aluno e que me ajudaram a 
efetivamente entender determinados assuntos. Quando é condizente, ou eu xeroco esses exercícios, ou eu os reproduzo e aplico em sala de aula. Às vezes, estes exercícios foram elaborados com a metodologia bastante diferente da que eu uso atualmente. Nesse tipo de situação, eu os readapto à minha realidade e à necessidade dos alunos.

Pergunta: Como você definiria, de forma espontânea, suas concepções de ensino, didática, práticas docentes, Lehrerverhalten [comportamento do professor em sala de aula], e as da instituição em que você trabalha?

Resposta: Acho que eles são muito claros quanto ao que eles querem, e eles querem padronizar, mesmo que não nos tolham, mesmo que digam que podemos ser nós mesmos. Quando a gente chega lá, precisa rever uma série de práticas para se adaptar à metodologia da casa. Tem a sequência das aulas, você por exemplo começar projetando a imagem, fazendo a Semantisierung [semantização], ativando conhecimentos prévios, enfim, daí você praticar a estrutura ou vocabulário novo com lacunas, e tal, e depois passar uma atividade criativa, em que eles criem efetivamente, enfim. Com a mudança das mesinhas para Café-Tische [mesinhas de café] eles disseram que estava provado que os alunos interagiriam mais, e temos que fazer eles pensarem, formular todas as regras, o SOS, participar com a história de vida deles, com as necessidades deles, o perfil do grupo. Essa coisa da interação e de fazer junto é imprescindível lá, e eu concordo plenamente com isso.

Pergunta: Qual é a sua formação acadêmica para ser professor de alemão, e qual é a sua experiência profissional?Você já viveu em um país de língua alemã?

Resposta: Eu trabalho aqui faz pouco mais de dois anos, mas na verdade já trabalhava na filial de [outra capital brasileira], o que totaliza uns 10 anos na instituição. Sou graduado em Letras, fiz o DLA e a especialização em ensino de alemão da UFBA. Estive na Alemanha diversas vezes fazendo cursos de Landeskunde [aspectos culturais na aula de ALE] e outros assuntos de didática, mas nunca passei mais de dois meses lá.

Pergunta: O que você poderia me contar sobre o trabalho com essa turma em particular? 
Resposta: A turma era composta por 8 pessoas, mas vieram 6 alunos no dia da aplicação do exercício. Esse grupo me chamava muito a atenção por se tratar de alunos bastante heterogêneos. Porém, em um aspecto eles estavam bastante equilibrados: um conhecimento superficial das estruturas básicas da língua alemã. Apesar de durante as aulas eles terem demonstrado a compreensão do assunto, toda vez, quando era necessária a criação de um exemplo cem por cento elaborado por eles, além das relativas, havia problemas de vocabulário, posição verbal, conjugação, pronúncia e, principalmente, interferência do português. Eles foram meus alunos no curso antes e ninguém sabia nada de alemão quando começaram no A1. É gente bem de vida, eu diria que pertencentes às classes $\mathrm{A}$ e $\mathrm{B}$ de acordo com os critérios do governo, graduados, vários pós-graduados, viajam muito. É até engraçado, você pergunta a eles como foram as férias para treinar o "Perfekt" [tempo verbal do passado do alemão] e eles respondem Griechenland [Grécia], Türkei [Turquia], USA... Alemanha, Áustria... ou fizeram USP ou particulares caríssimas. Na hora em que você explica a matéria nova, eles sempre demonstram com clareza que entenderam. Eles não têm dificuldade de aprendizado, mas depois esquecem tudo. Eles têm dificuldade na hora de produzir, de usar a língua, e de retomar aspectos passados, coisas estudadas alguns meses ou cursos antes.

Pergunta: Qual foi a preparação dos alunos para a aplicação dos exercícios?

Resposta: Eu expliquei que eles responderiam a uma pesquisa em que o assunto abordado era o mesmo que nós estávamos vendo em sala de aula. Atendendo ao seu pedido, expliquei antes de distribuir as folhas, em português mesmo, o significado da palavra "Roman". Eles se sentiram muito especiais ao colaborar com uma pesquisa de mestrado. Mas eu passei Hausaufgaben [deveres de casa] do Sprachtraining [livro de exercícios do kit studio d] também.

\section{Muito obrigado!}


Apêndice 3: A lista de exercícios

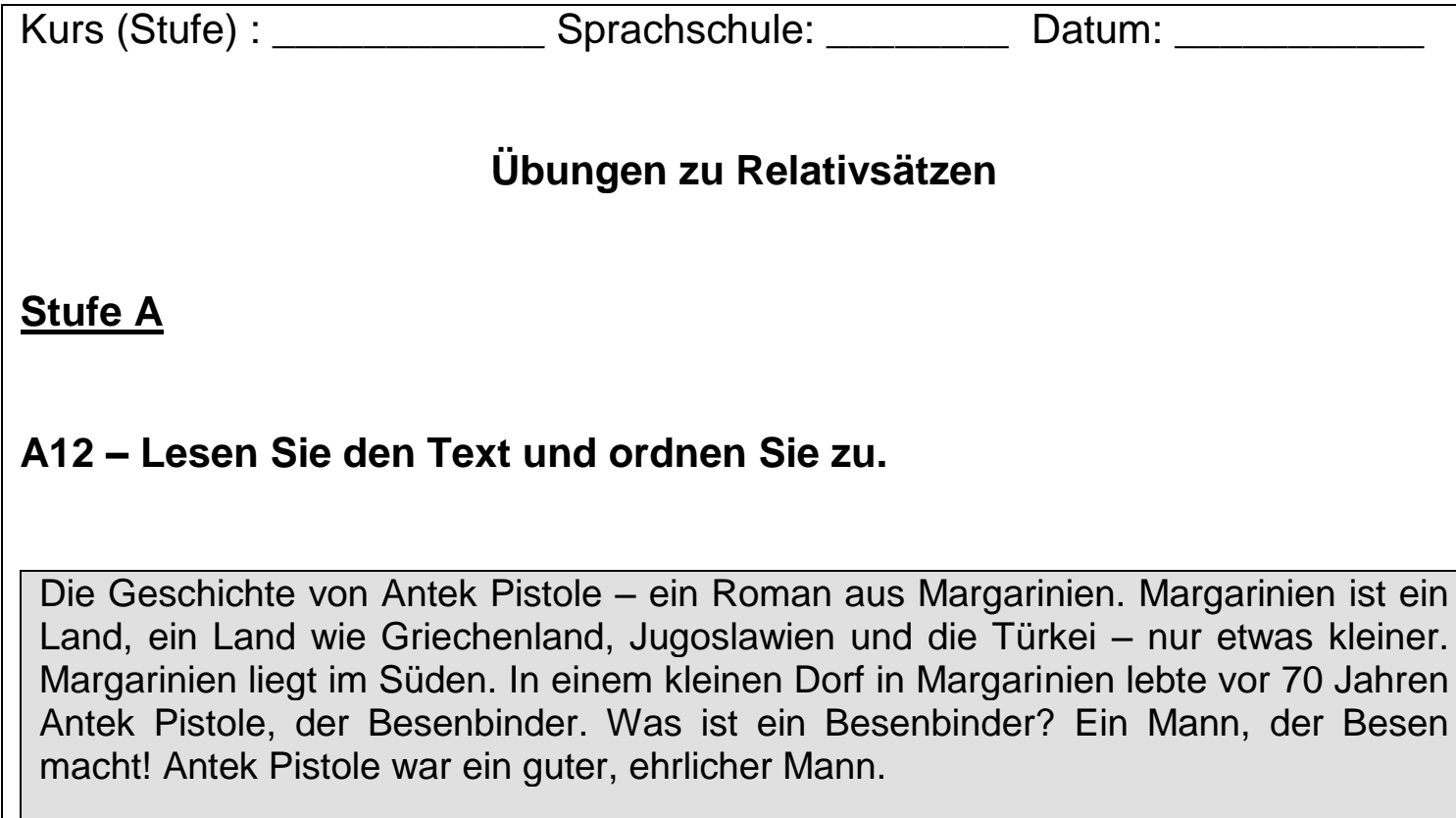

(Quelle: Deutsche Aktiv, Lehrbuch 1, S.120) - Neuner et al., 1981, p. 63.
a. Margarinien ist das Land,
1. der Besen machte.
b. Vor 70 Jahren lebte Antek,
2. das Antek produzierte.
c. Besen waren das Produkt,
3. in dem Pistole wohnte.
d. Man sagt, dass Antek ein Mann ist,
4. das größer ist.
e. Die Türkei ist ein Land,
5. der ehrlich war.

\section{Stufe B}

B12 - Ergänzen Sie die Sätze.

1. Das ist der Mann, den

2. Ich rede immer mit meiner Ärztin, der

3. Wir haben drei Kinder,

4. In der Sprachenschule, wir lernen,

5. Margarinien ist ein kleines Land, wohnte. 


\section{Stufe C}

C2 - Schreiben Sie die Sätze weiter.

\begin{tabular}{|l|l}
\hline Die Geschichte von & ist der Roman,
\end{tabular}

Antek Pistole

Zwischen Europa und liegt die Türkei,

Asien

\section{Stufe D}

Schreiben Sie einen Text (freies Thema), in dem mindestens 5 Relativsätze ercheinen (ca. 150 Wörter). 
ANEXO 
Anexo 1: Termo de consentimento livre e esclarecido

TERMO DE CONSENTIMENTO LIVRE E ESCLARECIDO

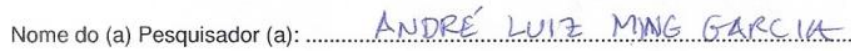

Você está sendo convidada (o) a participar desta pesquisa. Ao integrar este estudo estará permitindo a utilização dos dados aqui fornecidos. Você tem liberdade de se recusar a participar e ainda se recusar a continuar participando em qualquer fase da pesquisa, sem qualquer prejuízo pessoal.

Todas as informações coletadas neste estudo são estritamente confidenciais, você não precisará se identificar. Somente o (a) pesquisador (a) terá acesso às suas informaçōes e após o registro destas o documento será destruído.

\section{Consentimento Livre e Esclarecido}

Tendo em vista o esclarecimento acima apresentados, eu, manifesto livremente meu consentimento em participar da pesquisa.

\begin{tabular}{|l|l|l|}
\hline No & Nome do participante & Assinatura do participante \\
\hline 01 & & \\
\hline 02 & & \\
\hline 03 & & \\
\hline 04 & & \\
\hline 05 & & \\
\hline 06 & & \\
\hline 07 & & \\
\hline 08 & & \\
\hline 09 & & \\
\hline 10 & & \\
\hline 11 & & \\
\hline 12 & & \\
\hline 13 & & \\
\hline 14 & & \\
\hline 15 & & \\
\hline 16 & & \\
\hline 17 & & \\
\hline 18 & & \\
\hline 19 & & \\
\hline 20 & & \\
\hline 21 & & \\
\hline 22 & & \\
\hline 23 & & \\
\hline 24 & & \\
\hline 25 & & \\
\hline
\end{tabular}




\section{Anexo 2a: Exercícios grupo A (6 informantes, frente e verso)}

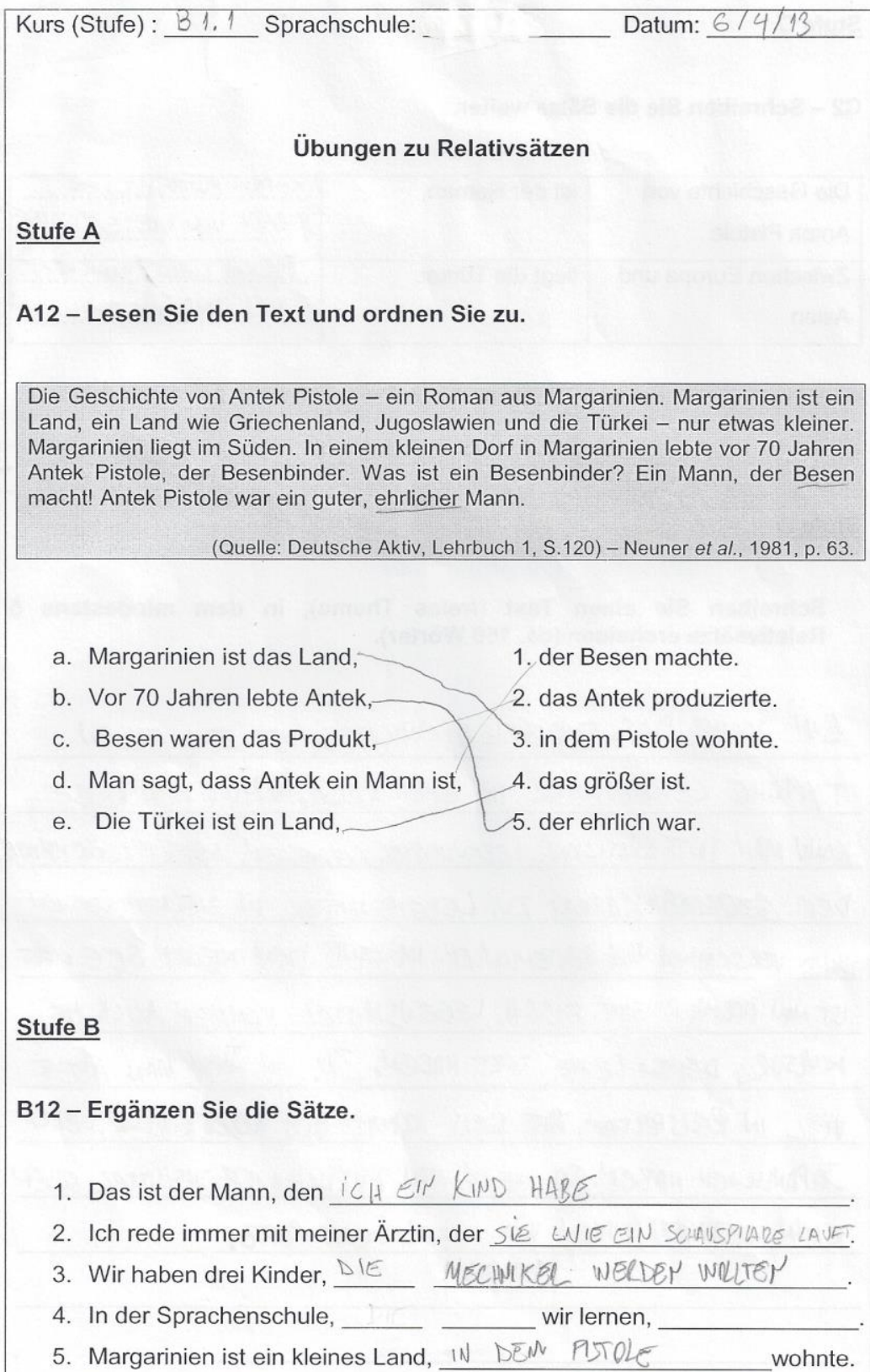




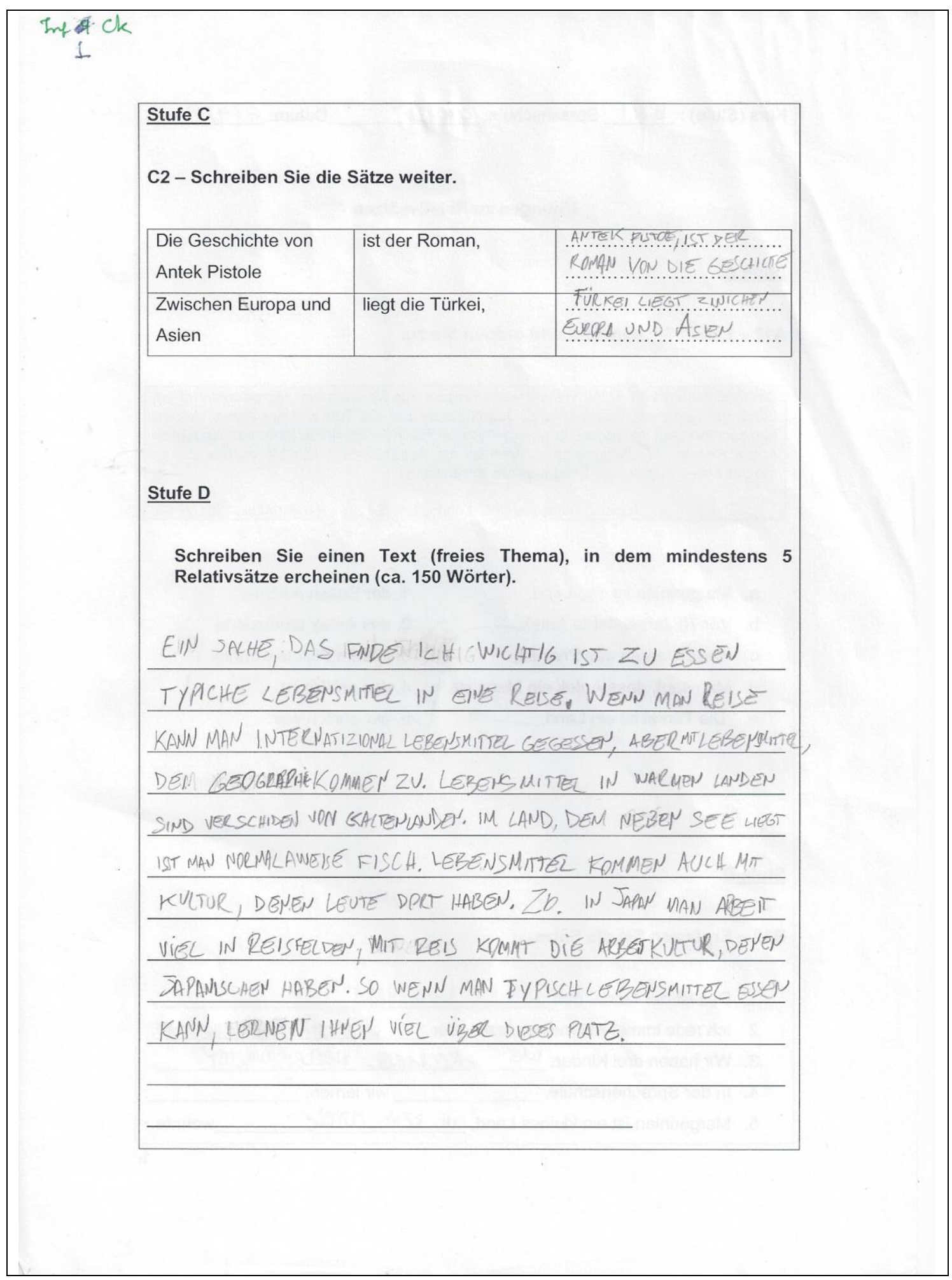




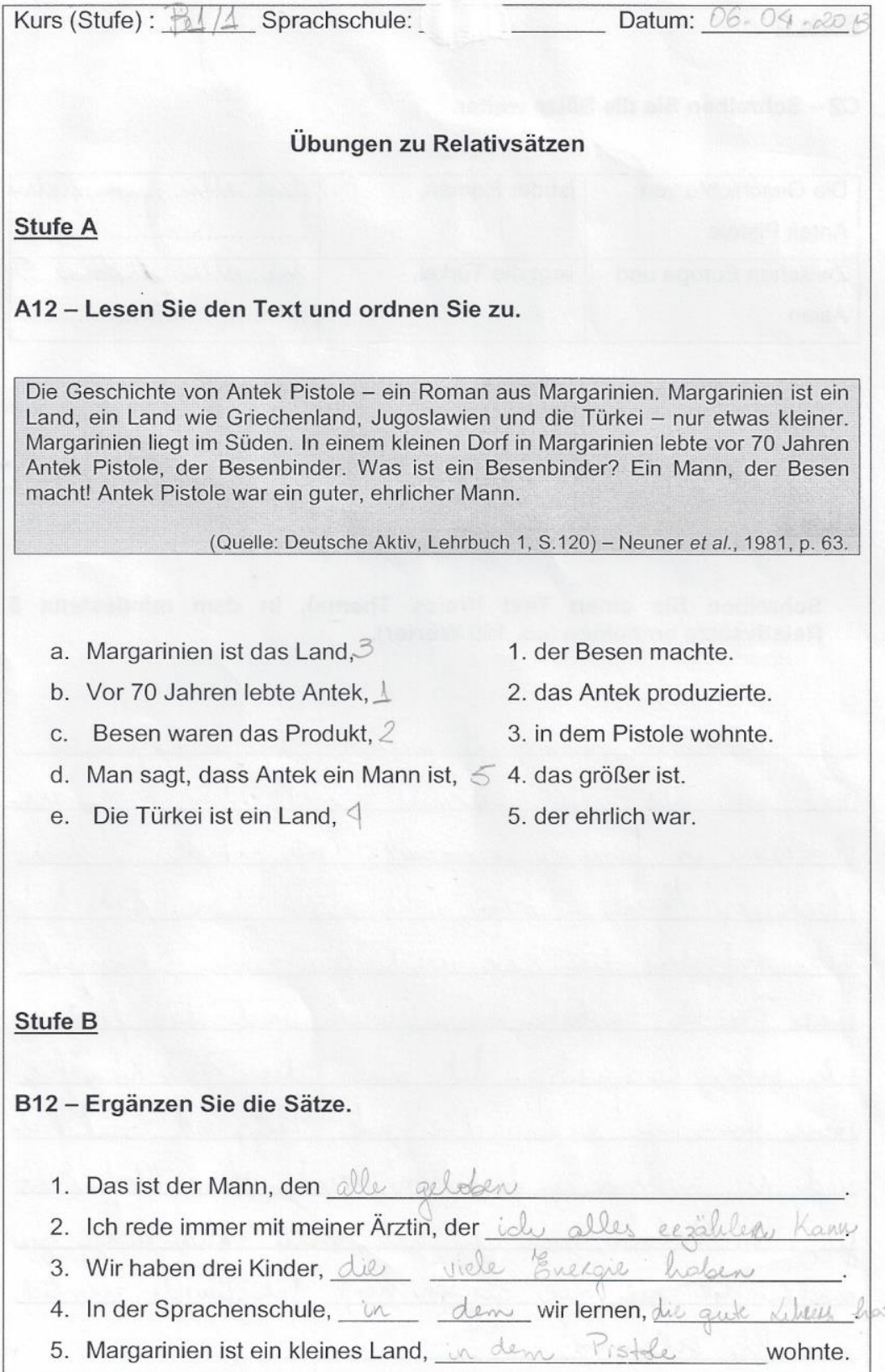


Inf \& ck

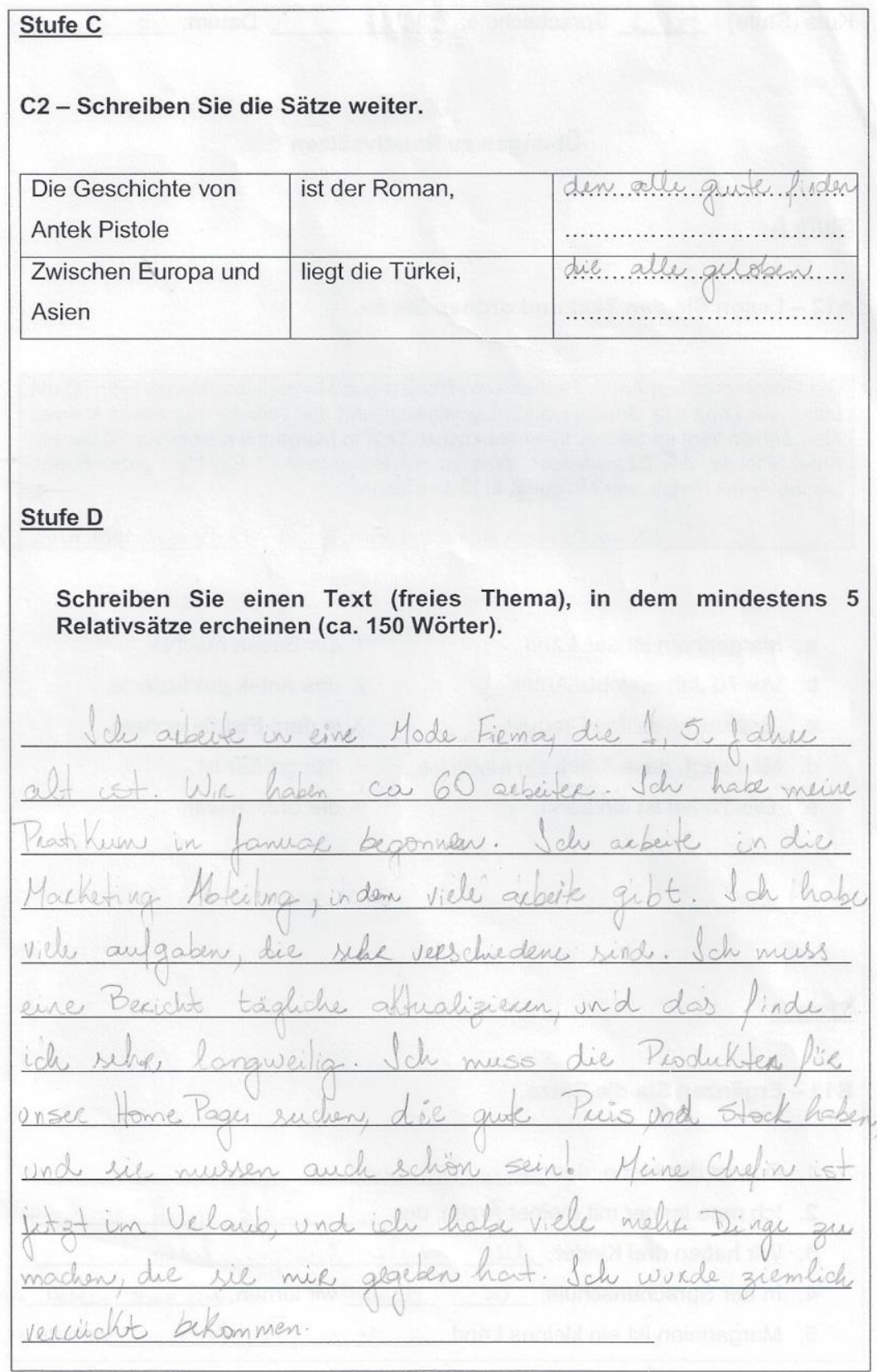




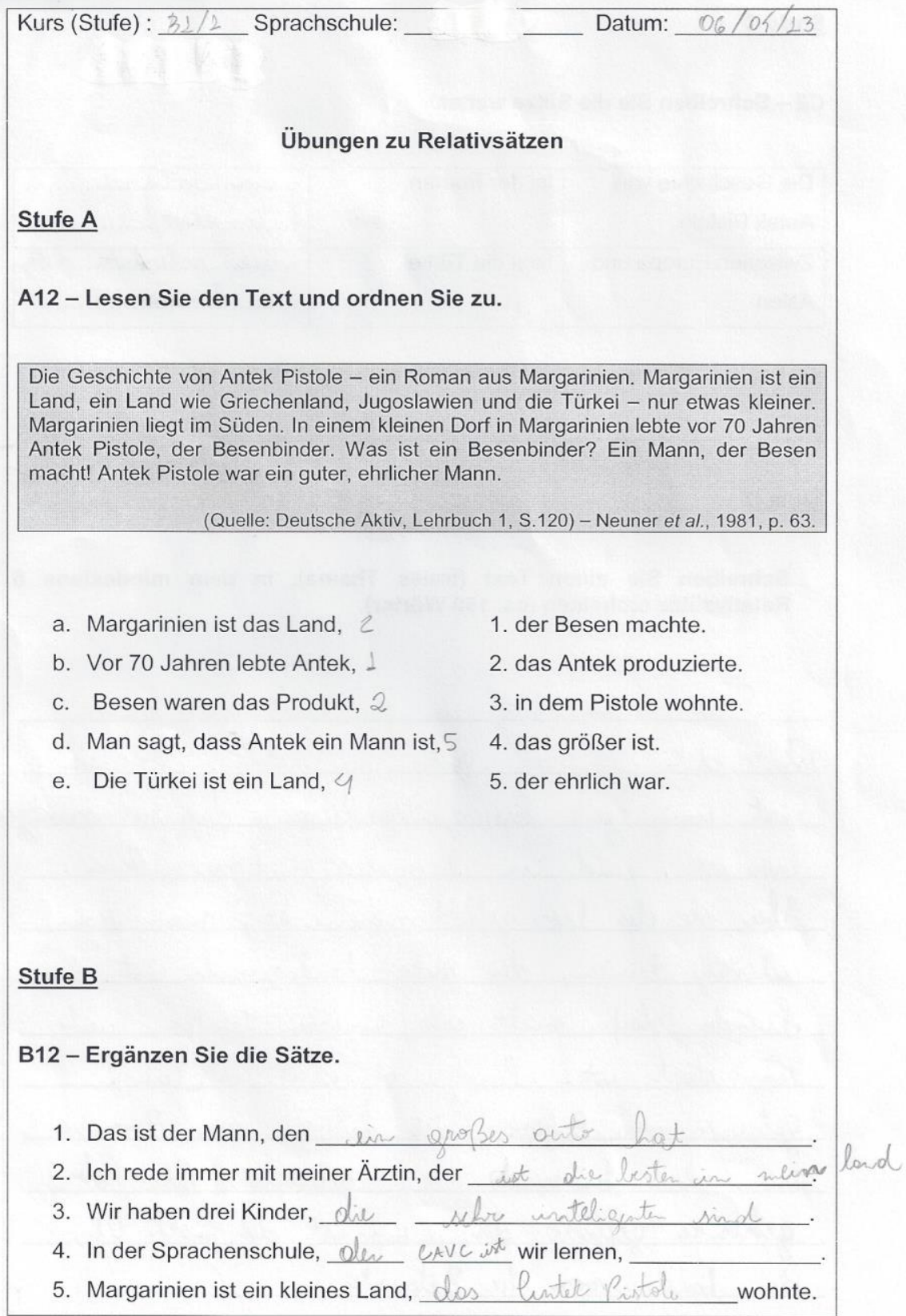


Inf ${ }_{3} \mathrm{CK}$

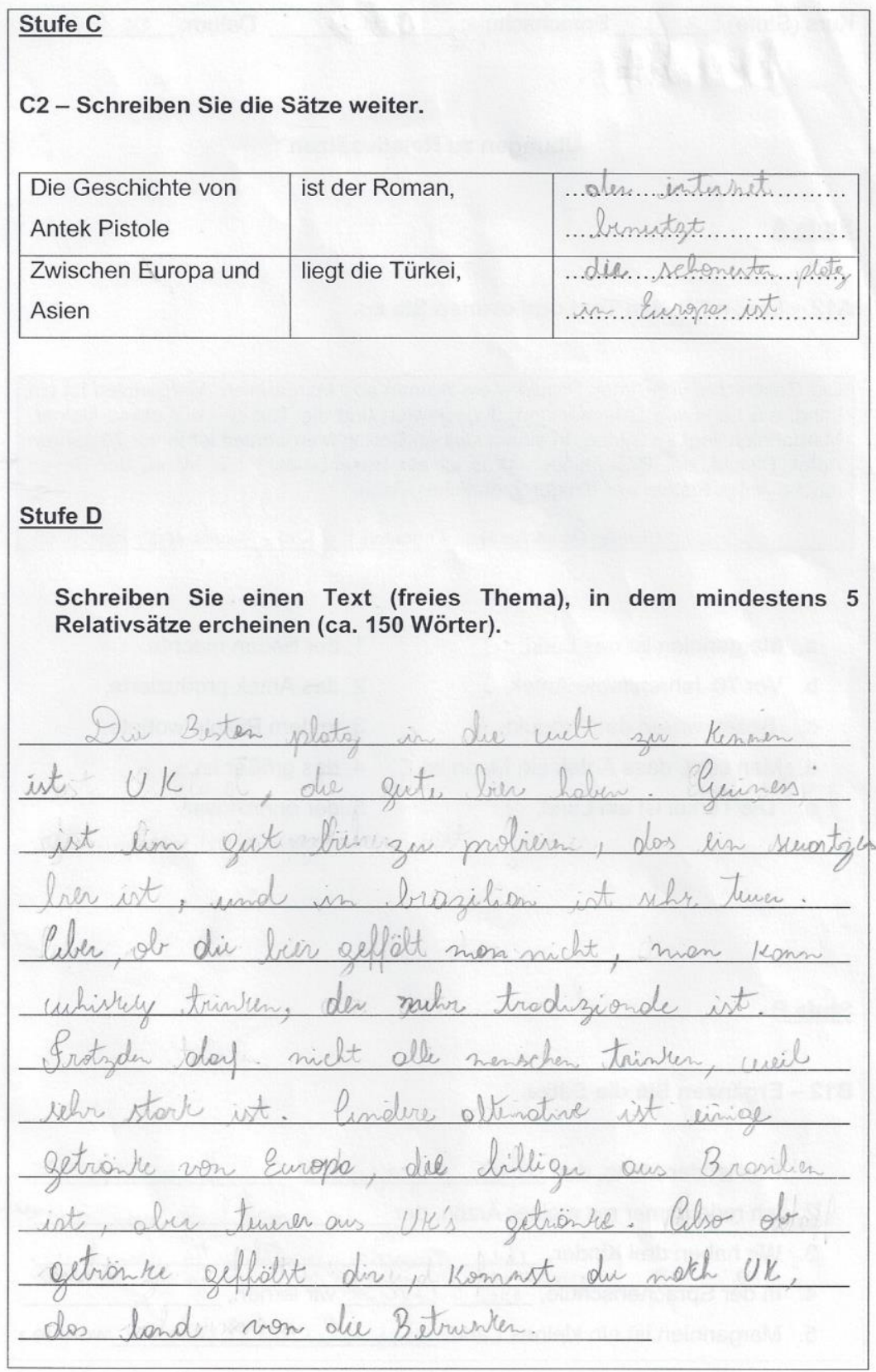




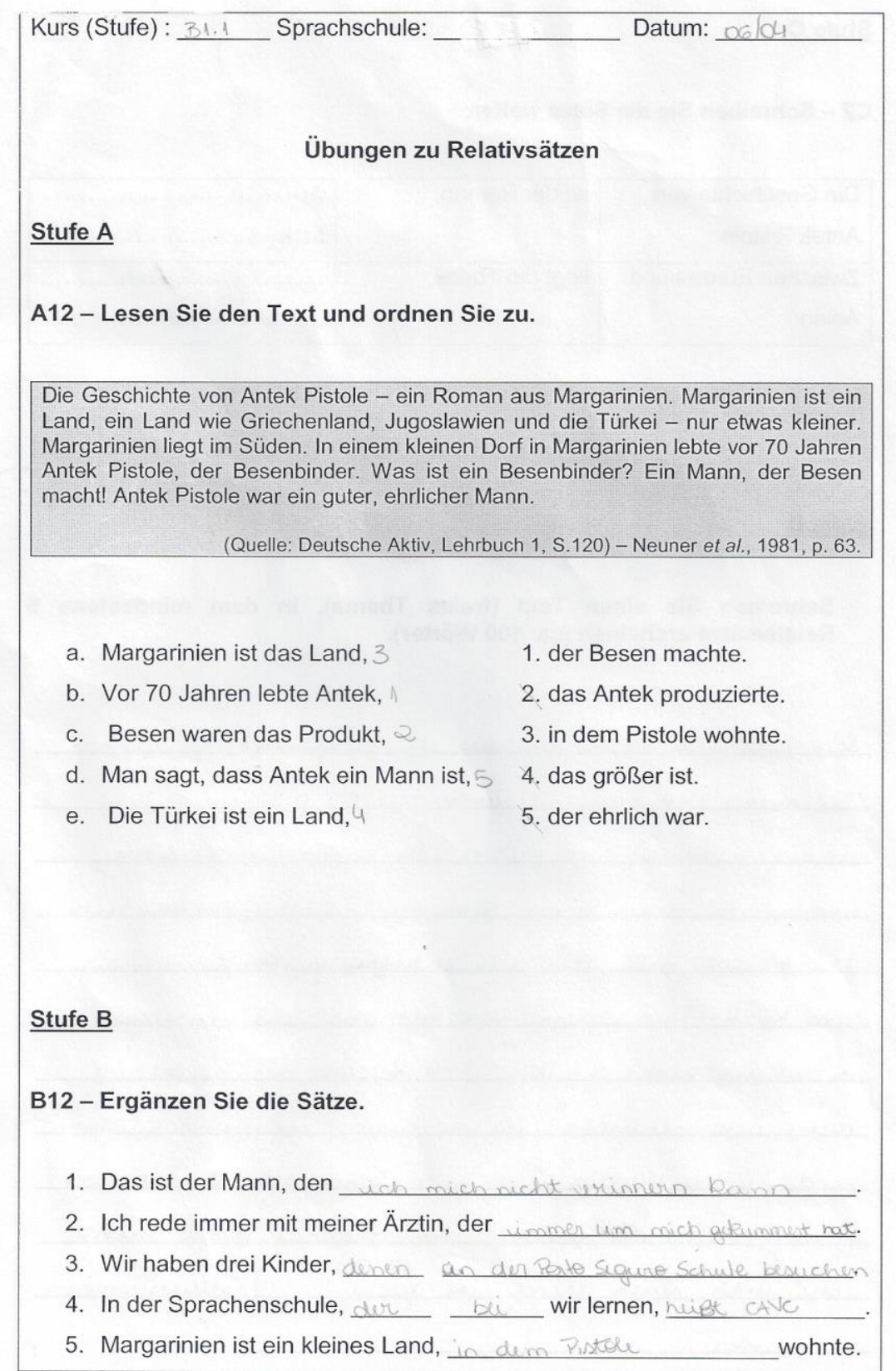


Inf 1 CK

Stufe C
C2 - Schreiben Sie die Sätze weiter.
\begin{tabular}{|l|l|l|}
\hline $\begin{array}{l}\text { Die Geschichte von } \\
\text { Antek Pistole }\end{array}$ & ist der Roman, & \\
\hline $\begin{array}{l}\text { Zwischen Europa und } \\
\text { Asien }\end{array}$ & liegt die Türkei, & \\
\hline
\end{tabular}

$\underline{\text { Stufe D }}$

Schreiben Sie einen Text (freies Thema), in dem mindestens 5 Relativsätze ercheinen (ca. 150 Wörter).

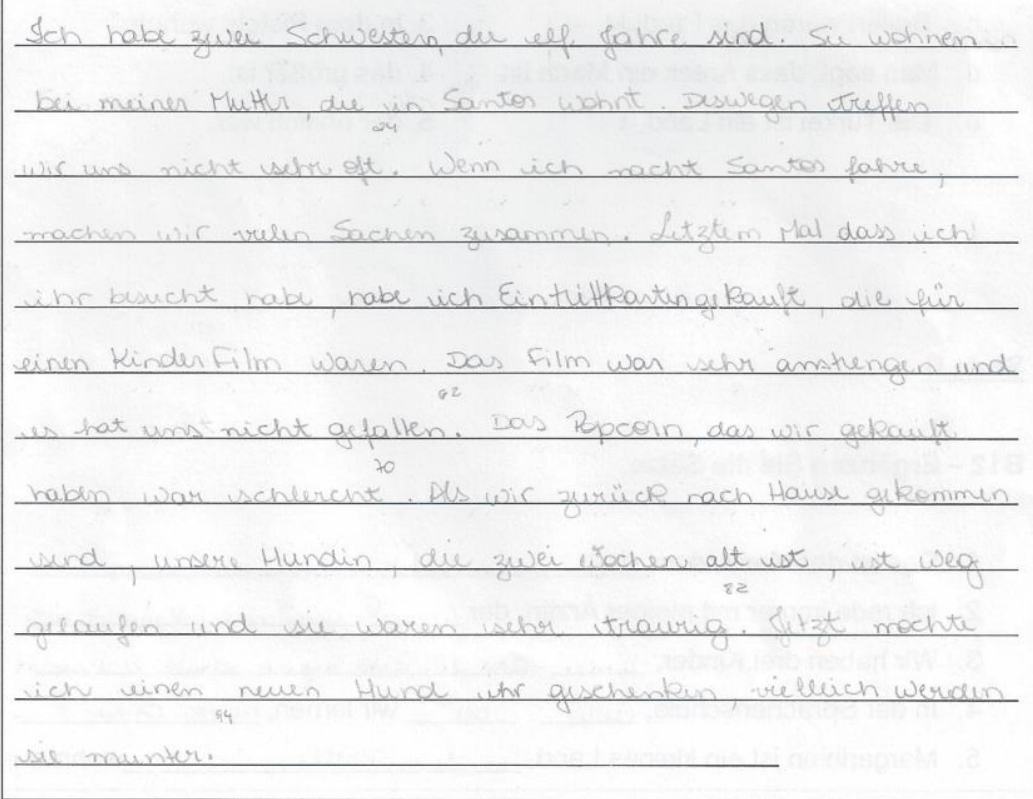




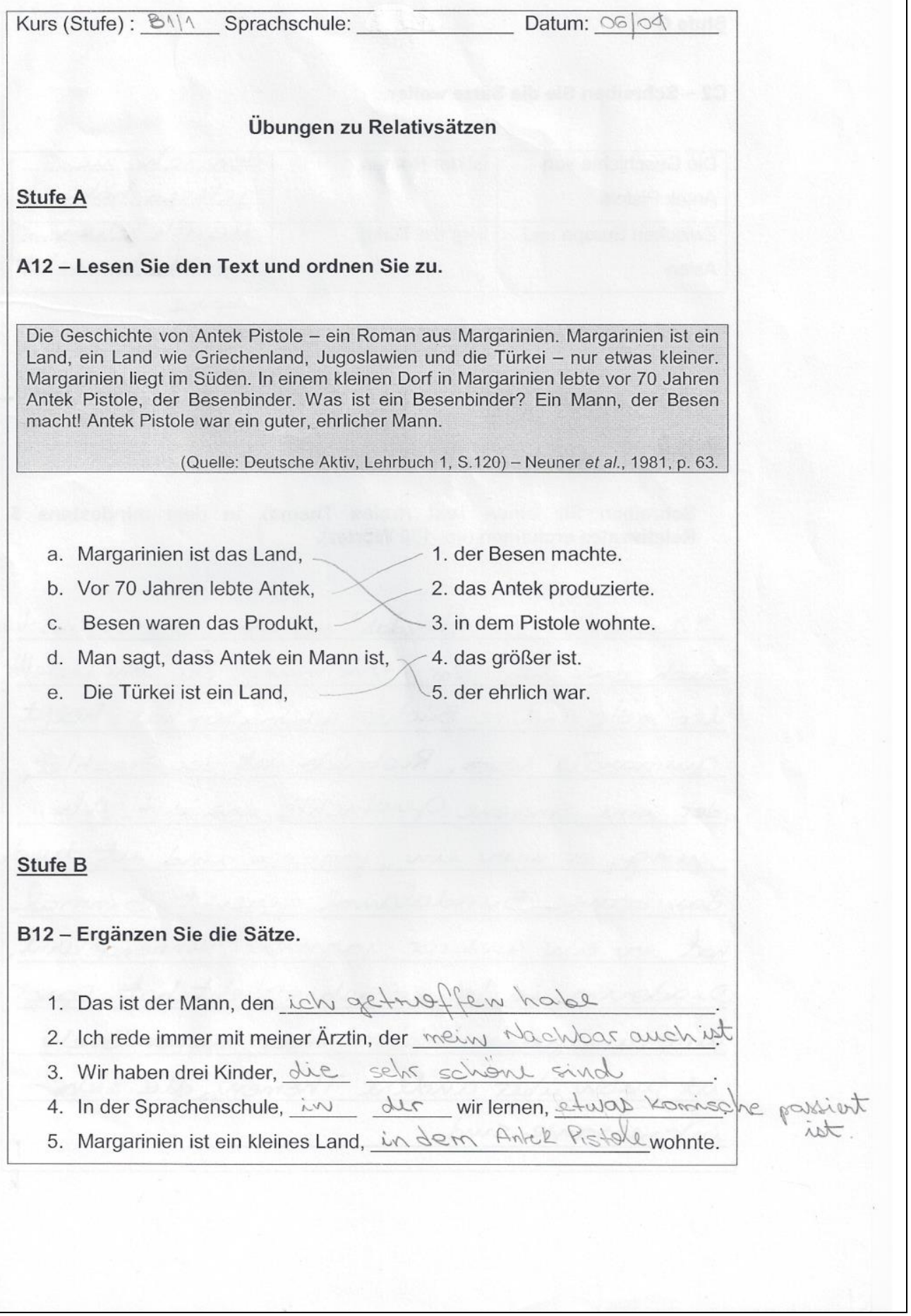


Int $\frac{1}{5} \mathrm{Ck}$

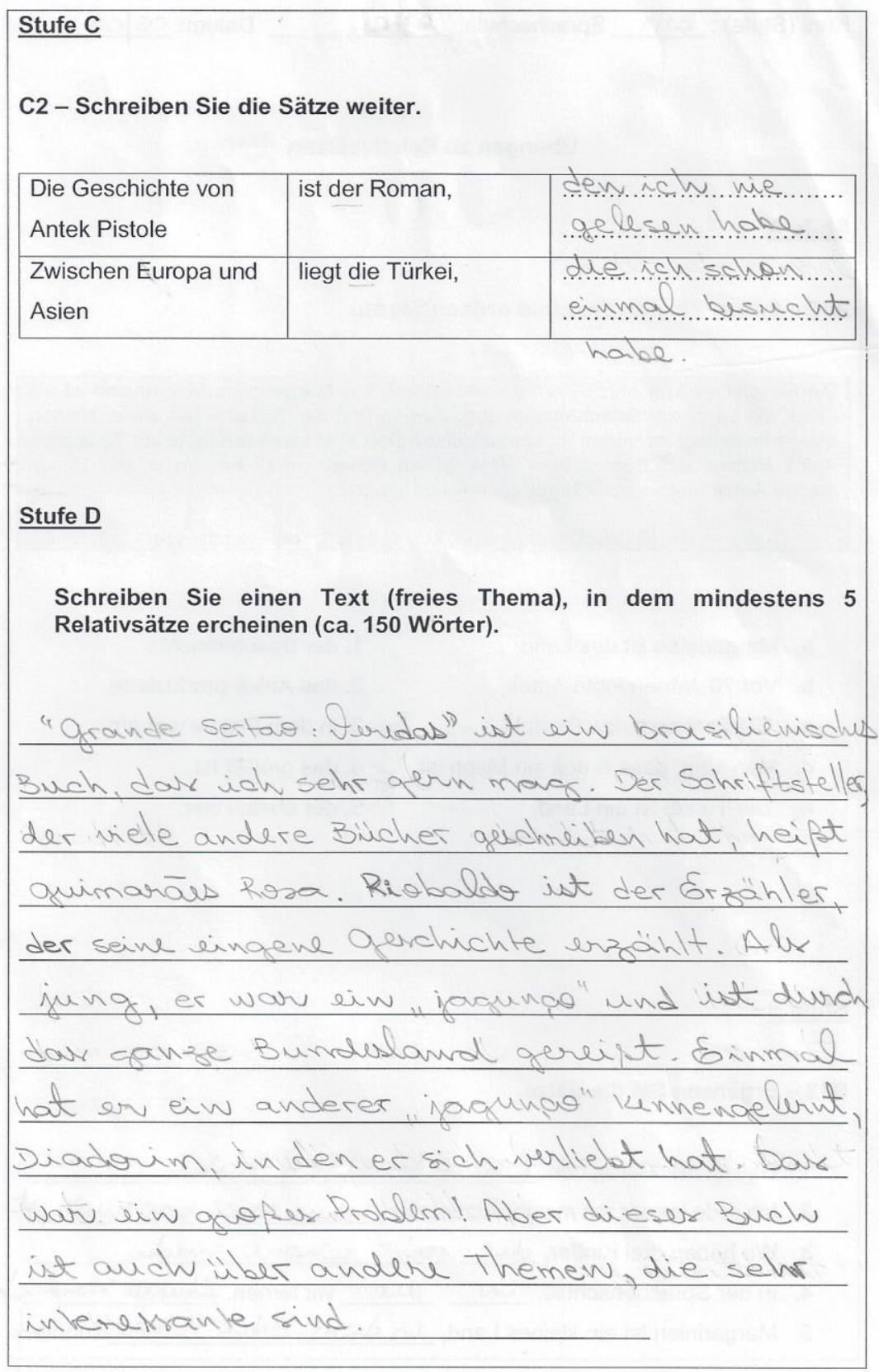




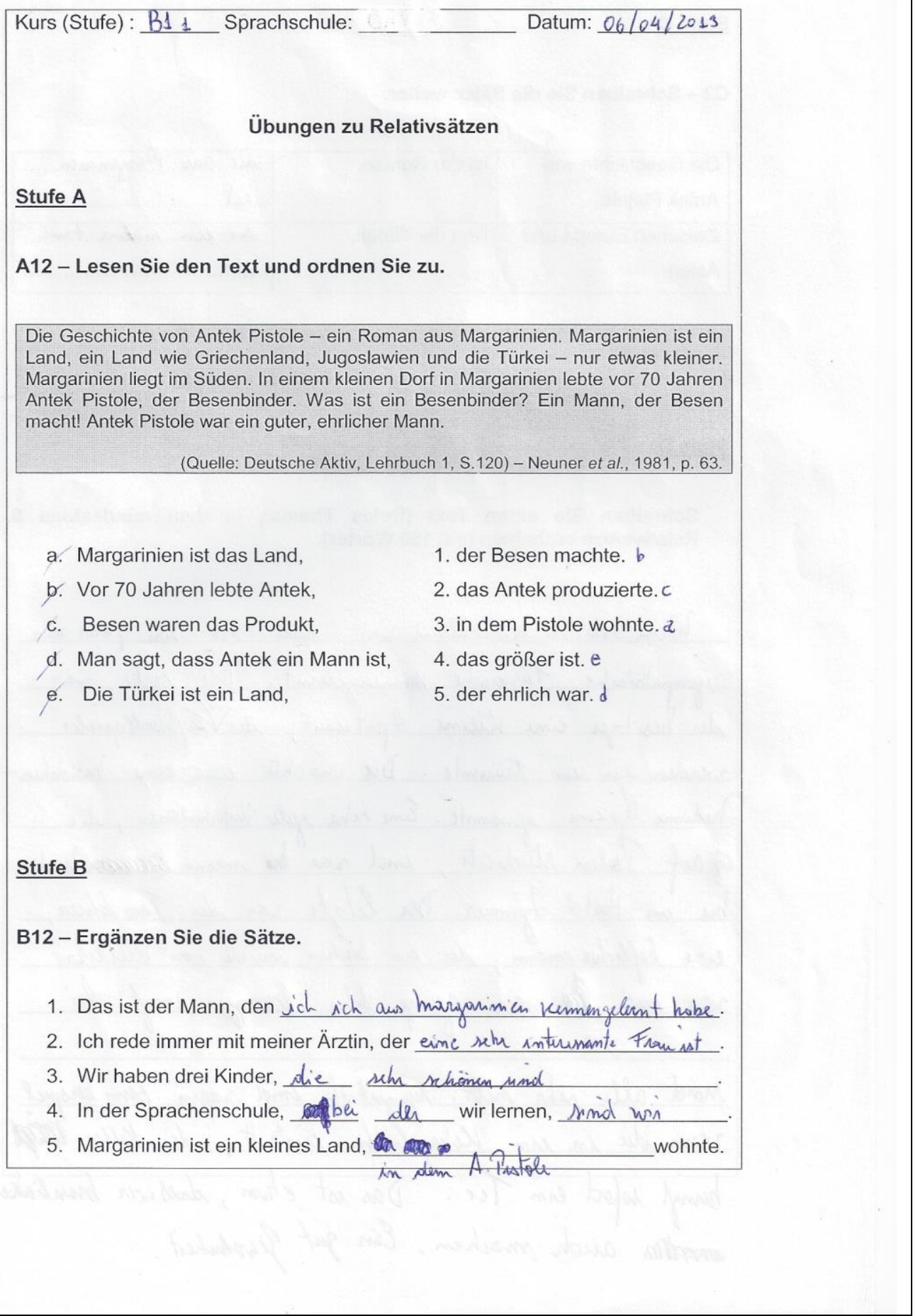


Int Cle

6

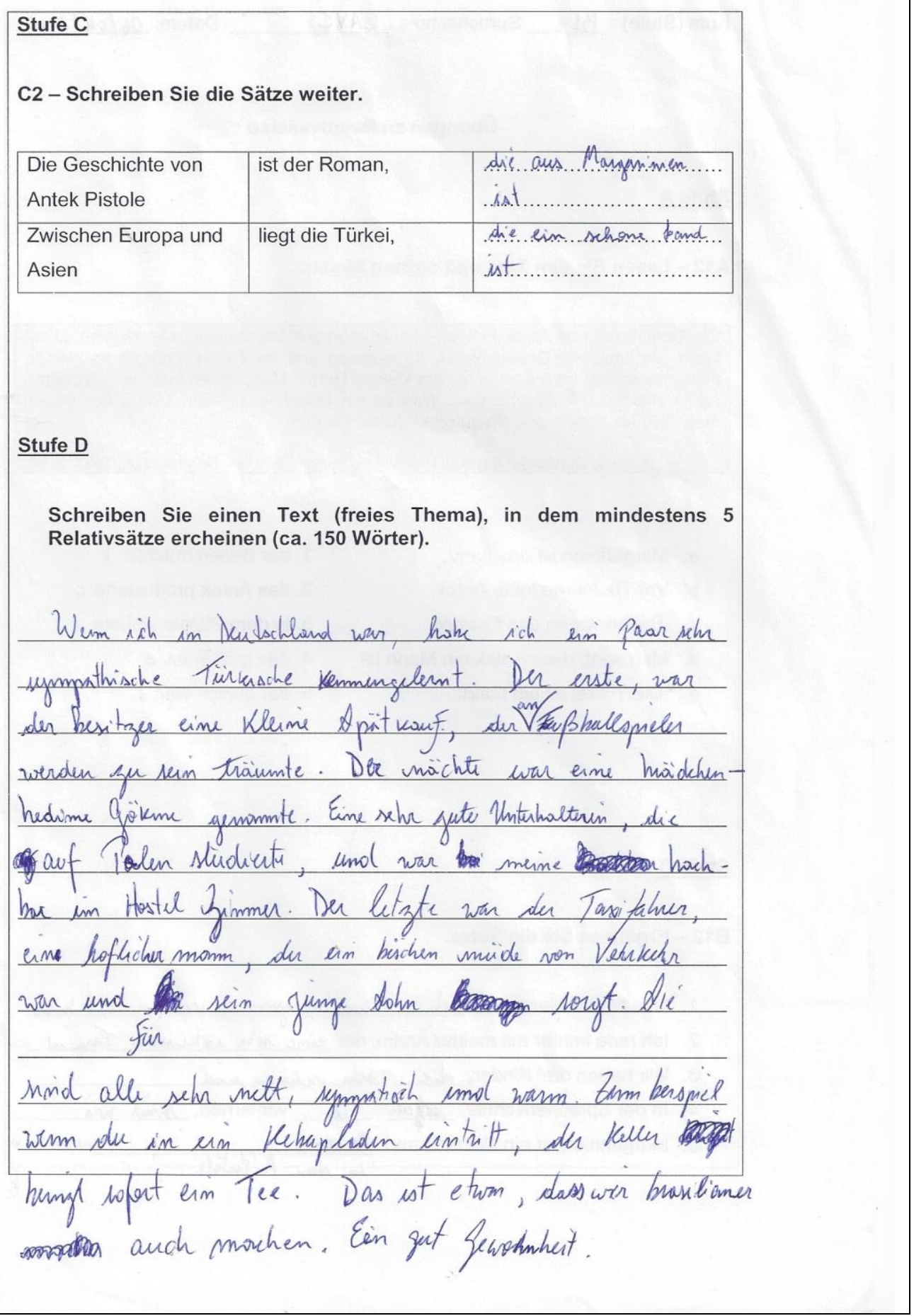




\section{Anexo 2b: Exercícios grupo B (6 informantes, frente e verso)}

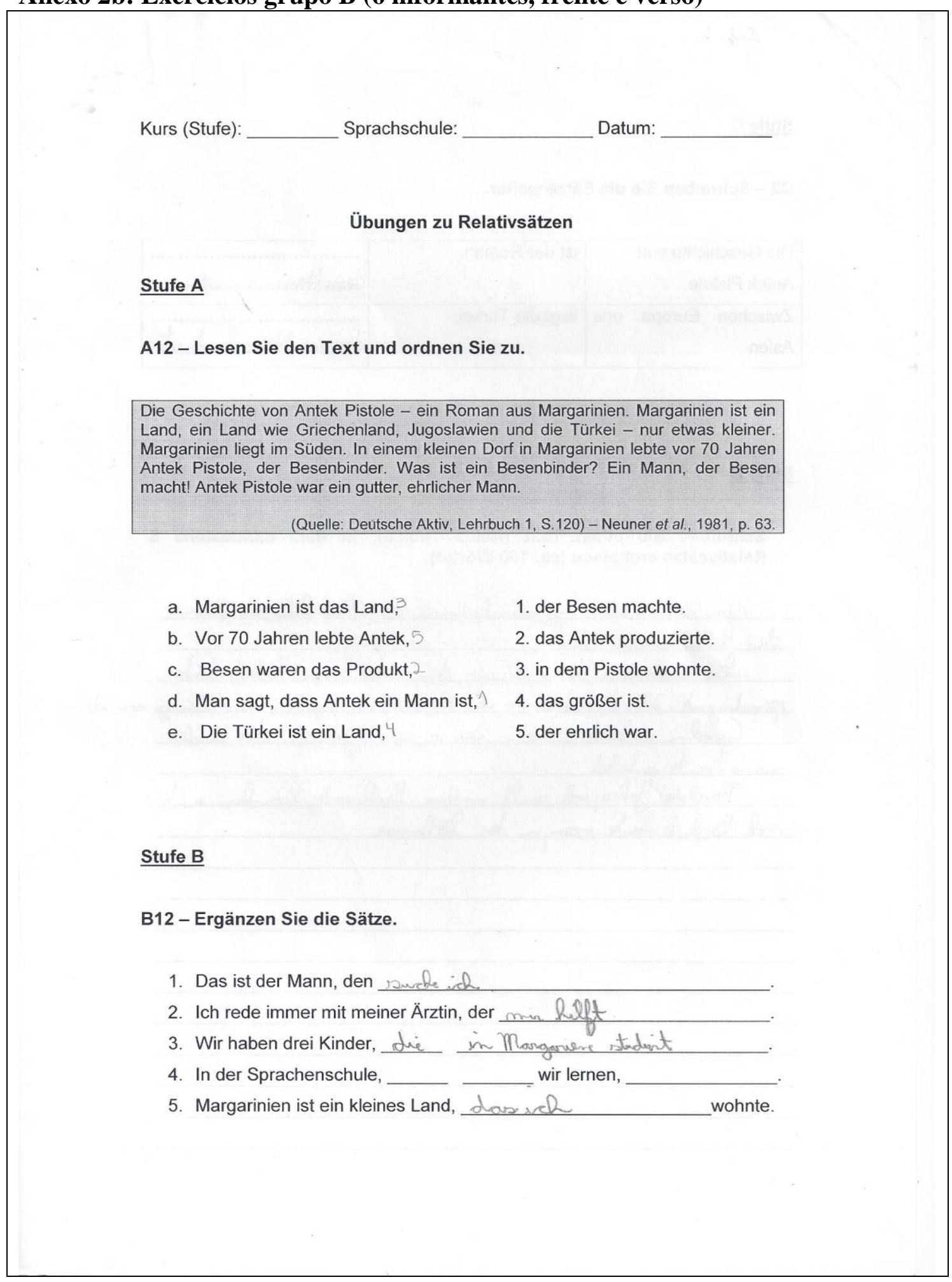


Inf. 1

$\underline{\text { Stufe C }}$

C2 - Schreiben Sie die Sätze weiter.

\begin{tabular}{|c|c|c|}
\hline $\begin{array}{l}\text { Die Geschichte von } \\
\text { Antek Pistole }\end{array}$ & ist der Roman, & 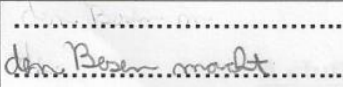 \\
\hline $\begin{array}{l}\text { Zwischen Europa uns } \\
\text { Asien }\end{array}$ & liegt die Türkei, & 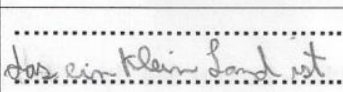 \\
\hline
\end{tabular}

\section{$\underline{\text { Stufe D }}$}

Schreiben Sie einen Text (freies Thema), in dem mindestens 5 Relativsätze ercheinen (ca. 150 Wörter).

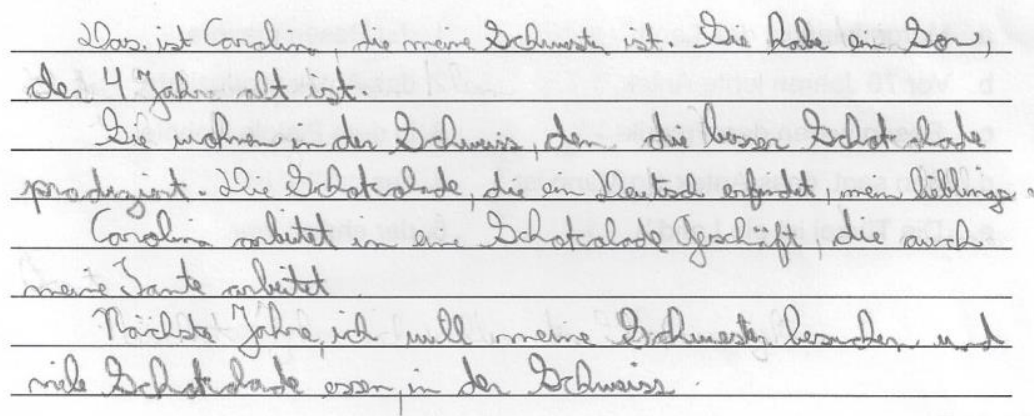


Kurs (Stufe): Sprachschule: Datum:

\section{Übungen zu Relativsätzen}

\section{$\underline{\text { Stufe A }}$}

\section{A12 - Lesen Sie den Text und ordnen Sie zu.}

Die Geschichte von Antek Pistole - ein Roman aus Margarinien. Margarinien ist ein Land, ein Land wie Griechenland, Jugoslawien und die Türkei - nur etwas kleiner. Margarinien liegt im Süden. In einem kleinen Dorf in Margarinien lebte vor 70 Jahren Antek Pistole, der Besenbinder. Was ist ein Besenbinder? Ein Mann, der Besen macht! Antek Pistole war ein gutter, ehrlicher Mann

(Quelle: Deutsche Aktiv, Lehrbuch 1, S.120) - Neuner et al., 1981, p. 63.
a. Margarinien ist das Land,
1. der Besen machte.
b. Vor 70 Jahren lebte Antek,
2. das Antek produzierte.
c. Besen waren das Produkt,
3. in dem Pistole wohnte.
d. Man sagt, dass Antek ein Mann ist,
4. das größer ist.
e. Die Türkei ist ein Land,
5. der ehrlich war.

\section{$\underline{\text { Stufe B }}$}

\section{B12 - Ergänzen Sie die Sätze.}

1. Das ist der Mann, den ich letze Montrog loto orolivet.

2. Ich rede immer mit meiner Ärztin, der ich arotul ient hobe.

3. Wir haben drei Kinder, die sin sehule sind..

4. In der Sprachenschule, ___ wir lernen,

5. Margarinien ist ein kleines Land, ir dem Piitale wohnte. 
$\operatorname{Inf} \cdot 2$

$\underline{\text { Stufe C }}$

C2 - Schreiben Sie die Sätze weiter.

\begin{tabular}{|c|c|c|}
\hline $\begin{array}{l}\text { Die Geschichte von } \\
\text { Antek Pistole }\end{array}$ & ist der Roman, & 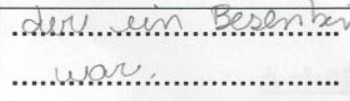 \\
\hline $\begin{array}{l}\text { Zwischen Europa un\$ } \\
\text { Asien }\end{array}$ & liegt die Türkei, & 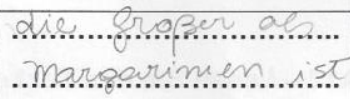 \\
\hline
\end{tabular}

$\underline{\text { Stufe D }}$

Schreiben Sie einen Text (freies Thema), in dem mindestens 5 Relativsätze ercheinen (ca. 150 Wörter).

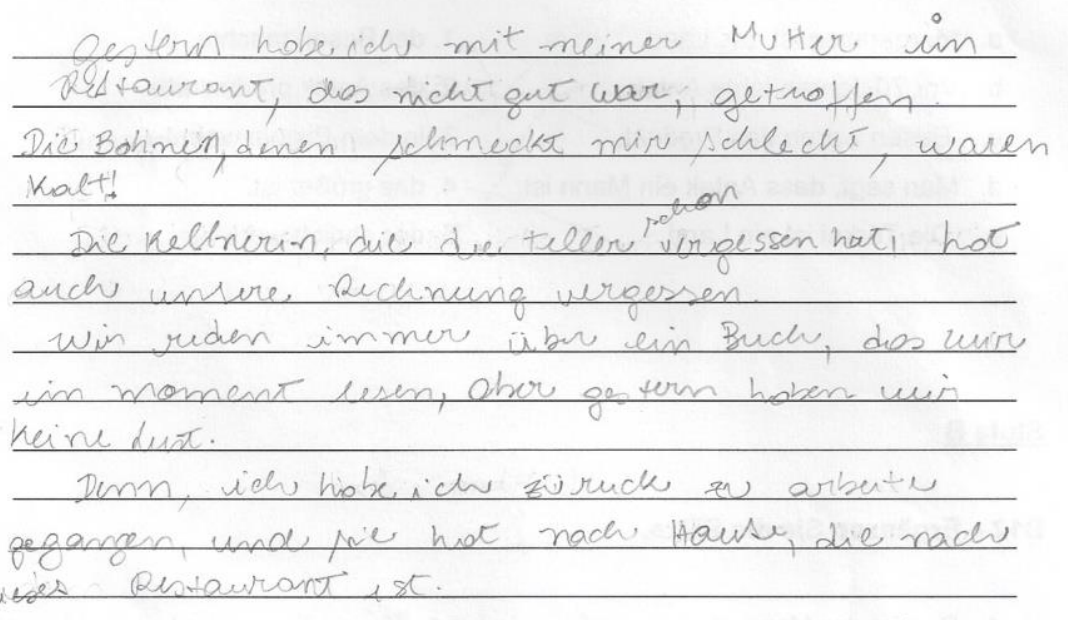

Lises Restautant ist. 
Kurs (Stufe): A.2.2 Sprachschule: _ _ Datum: 07.11 .2012

\section{Übungen zu Relativsätzen}

\section{$\underline{\text { Stufe A }}$}

\section{A12 - Lesen Sie den Text und ordnen Sie zu.}

Die Geschichte von Antek Pistole - ein Roman aus Margarinien. Margarinien ist ein
Land, ein Land wie Griechenland, Jugoslawien und die Türkei - nur etwas kleiner.
Margarinien liegt im Süden. In einem kleinen Dorf in Margarinien lebte vor 70 Jahren
Antek Pistole, der Besenbinder. Was ist ein Besenbinder? Ein Mann, der Besen
macht! Antek Pistole war ein gutter, ehrlicher Mann.
(Quelle: Deutsche Aktiv, Lehrbuch 1, S.120) - Neuner et al., 1981, p. 63.
a. Margarinien ist das Land,
1. der Besen machte.
b. Vor 70 Jahren lebte Antek,
2. das Antek produzierte.
c. Besen waren das Produkt,
(3.) in dem Pistole wohnte.
d. Man sagt, dass Antek ein Mann ist,
4. das größer ist.
e. Die Türkei ist ein Land,
5. der ehrlich war.

\section{$\underline{\text { Stufe B }}$}

\section{B12 - Ergänzen Sie die Sätze.}

1. Das ist der Mann, den ich nicht kenne

2. Ich rede immer mit meiner Ärztin, der ich seit

3. Wir haben drei Kinder, mit denen wir leben

4. In der Sprachenschule, in der wir lernen, machen wir viel. Spaß

5. Margarinien ist ein kleines Land, das meine Tante wohnte. 
Inf 3

$\underline{\text { Stufe C }}$

C2 - Schreiben Sie die Sätze weiter.

\begin{tabular}{|c|c|c|}
\hline $\begin{array}{l}\text { Die Geschichte von } \\
\text { Antek Pistole }\end{array}$ & ist der Roman, & 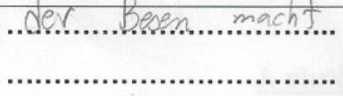 \\
\hline $\begin{array}{l}\text { Zwischen Europa uns } \\
\text { Asien }\end{array}$ & liegt die Türkei, & 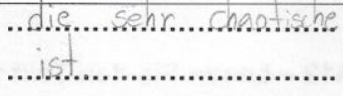 \\
\hline
\end{tabular}

\section{Stufe D}

Schreiben Sie einen Text (freies Thema), in dem mindestens 5 Relativsätze ercheinen (ca. 150 Wörter).

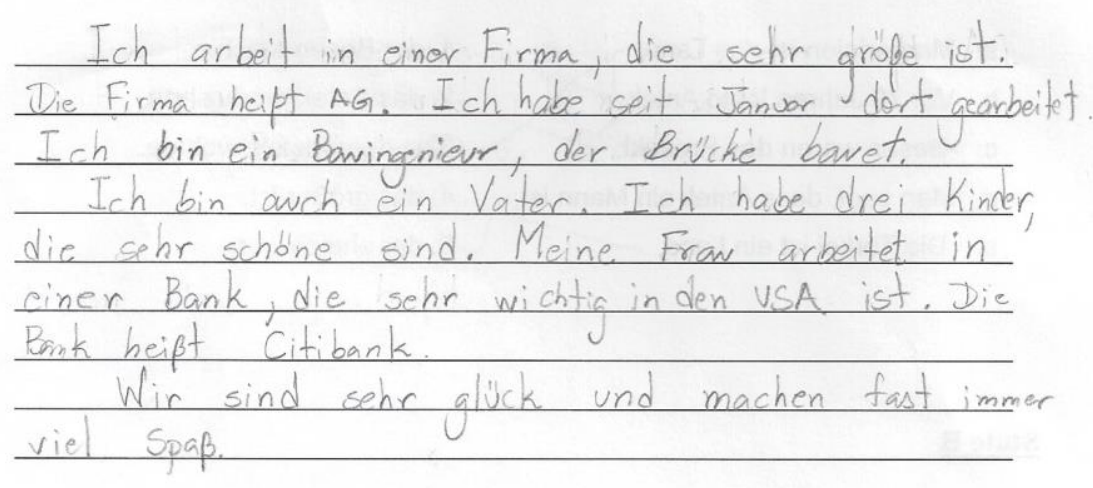




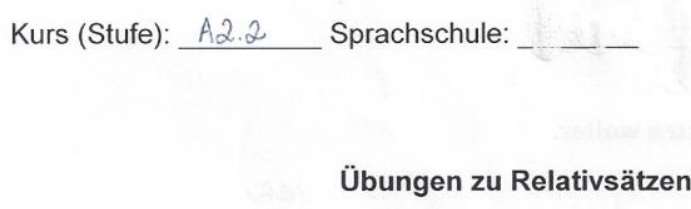

Datum: $7 \mid 11 / 2012$

\section{$\underline{\text { Stufe A }}$}

A12 - Lesen Sie den Text und ordnen Sie zu.

Die Geschichte von Antek Pistole - ein Roman aus Margarinien. Margarinien ist ein Land, ein Land wie Griechenland, Jugoslawien und die Türkei - nur etwas kleiner. Margarinien liegt im Süden. In einem kleinen Dorf in Margarinien lebte vor 70 Jahren Antek Pistole, der Besenbinder. Was ist ein Besenbinder? Ein Mann, der Besen macht! Antek Pistole war ein gutter, ehrlicher Mann.

(Quelle: Deutsche Aktiv, Lehrbuch 1, S.120) - Neuner et al., 1981, p. 63.
a. Margarinien ist das Land, 1. der Besen machte.
b. Vor 70 Jahren lebte Antek, 2. das Antek produzierte.
C. Besen waren das Produkt, 3 . in dem Pistole wohnte.
d. Man sagt, dass Antek ein Mann ist, 4. das größer ist.
e. Die Türkei ist ein Land, 5. der ehrlich war.

\section{$\underline{\text { Stufe B }}$}

B12 - Ergänzen Sie die Sätze.

1. Das ist der Mann, den ich gesehen habe.

2. Ich rede immer mit meiner Ärztin, der ich gratuliert habe

3. Wir haben drei Kinder, die sehe trourig sind

4. In der Sprachenschule, in wir lernen, gibt est viele feute

5. Margarinien ist ein kleines Land, in dem ich wohnte. 


\section{Inf 4}

\section{$\underline{\text { Stufe C }}$}

C2 - Schreiben Sie die Sätze weiter.

der

\begin{tabular}{|c|c|c|}
\hline $\begin{array}{l}\text { Die Geschichte von } \\
\text { Antek Pistole }\end{array}$ & ist der Roman, & 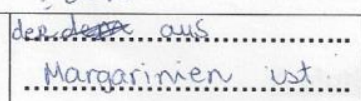 \\
\hline $\begin{array}{l}\text { Zwischen Europa uns } \\
\text { Asien }\end{array}$ & liegt die Türkei, & madie...sehr....shbon. \\
\hline
\end{tabular}

\section{$\underline{\text { Stufe D }}$}

Schreiben Sie einen Text (freies Thema), in dem mindestens 5 Relativsätze ercheinen (ca. 150 Wörter).

Ioh wohne in Sáo Paulo, die eine grope Stadt ist, aber ich pomme aus Rio de Janeiro, die schöner als sáo paulo ist.

Ich arbeite bei ein Verlag, das nur Bücher produziert. Da arbeite ich gern mit meine kollegen, die interessante sind.

Am Wochenende fahre ich oft mach Rio wo meine familie wohnt. In meine familie gehören meine Mutter, mein vater und meine Schwester, die dehrerin ist. 
Kurs (Stufe): Sprachschule: Datum: 7. 11.12

\section{Übungen zu Relativsätzen}

\section{$\underline{\text { Stufe A }}$}

\section{A12 - Lesen Sie den Text und ordnen Sie zu.}

Die Geschichte von Antek Pistole - ein Roman aus Margarinien. Margarinien ist ein Land, ein Land wie Griechenland, Jugoslawien und die Türkei - nur etwas kleiner. Margarinien liegt im Süden. In einem kleinen Dorf in Margarinien lebte vor 70 Jahren Antek Pistole, der Besenbinder. Was ist ein Besenbinder? Ein Mann, der Besen macht! Antek Pistole war ein gutter, ehrlicher Mann

(Quelle: Deutsche Aktiv, Lehrbuch 1, S.120) - Neuner et al., 1981, p. 63.
a. Margarinien ist das Land, 3
1. der Besen machte.
b. Vor 70 Jahren lebte Antek, 5
2. das Antek produzierte.
c. Besen waren das Produkt, 2
3. in dem Pistole wohnte.
d. Man sagt, dass Antek ein Mann ist, 1
4. das größer ist.
e. Die Türkei ist ein Land, 4
5. der ehrlich war.

\section{$\underline{\text { Stufe B }}$}

\section{B12 - Ergänzen Sie die Sätze.}

1. Das ist der Mann, den Ich mag nicht

2. Ich rede immer mit meiner Ärztin, der Lopfschmenen th habe.

3. Wir haben drei Kinder, die in die schule aehen

4. In der Sprachenschule, _— wir lernen, Deutsch

5. Margarinien ist ein kleines Land, das Ante $K$ wohnte. 
Inf S

$\underline{\text { Stufe C }}$

C2 - Schreiben Sie die Sätze weiter.

\begin{tabular}{|c|c|c|}
\hline $\begin{array}{l}\text { Die Geschichte von } \\
\text { Antek Pistole }\end{array}$ & ist der Roman, & der...Resen...macht... \\
\hline $\begin{array}{l}\text { Zwischen Europa uns } \\
\text { Asien }\end{array}$ & liegt die Türkei, & 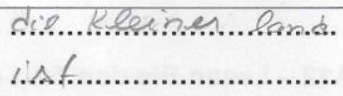 \\
\hline
\end{tabular}

$\underline{\text { Stufe D }}$

Schreiben Sie einen Text (freies Thema), in dem mindestens 5 Relativsätze ercheinen (ca. 150 Wörter).

Ich habe ein son, den 4 rahie alt ist meine Fram ist student, die gonze too anbeitet. die gonge Ich will meh zeit mit meinem son habe, der ju viele jeit in der schule hat 
Kurs (Stufe): Sprachschule: Datum:

\section{Übungen zu Relativsätzen}

\section{$\underline{\text { Stufe A }}$}

A12 - Lesen Sie den Text und ordnen Sie zu.

Die Geschichte von Antek Pistole - ein Roman aus Margarinien. Margarinien ist ein Land, ein Land wie Griechenland, Jugoslawien und die Türkei - nur etwas kleiner. Margarinien liegt im Süden. In einem kleinen Dorf in Margarinien lebte vor 70 Jahren Antek Pistole, der Besenbinder. Was ist ein Besenbinder? Ein Mann, der Besen macht! Antek Pistole war ein gutter, ehrlicher Mann.

(Quelle: Deutsche Aktiv, Lehrbuch 1, S.120) - Neuner et al., 1981, p. 63.
a. Margarinien ist das Land, 3
1. der Besen machte.
b. Vor 70 Jahren lebte Antek,
2. das Antek produzierte.
c. Besen waren das Produkt, 2
3. in dem Pistole wohnte.
d. Man sagt, dass Antek ein Mann ist, 5
4. das größer ist.
e. Die Türkei ist ein Land, 4
5. der ehrlich war.

\section{$\underline{\text { Stufe B }}$}

\section{B12 - Ergänzen Sie die Sätze.}

1. Das ist der Mann, den bentschkury lenst

2. Ich rede immer mit meiner Ärztin, der meinen freund lielt

3. Wir haben drei Kinder, deven in Schule sturdienew.

4. In der Sprachenschule, mit dew wir lernen, ist fröper.

5. Margarinien ist ein kleines Land, den Antek Psthle wohnte. 
Inf 6

$\underline{\text { Stufe C }}$

C2 - Schreiben Sie die Sätze weiter.

\begin{tabular}{|c|c|c|}
\hline $\begin{array}{l}\text { Die Geschichte von } \\
\text { Antek Pistole }\end{array}$ & ist der Roman, & 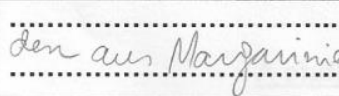 \\
\hline $\begin{array}{l}\text { Zwischen Europa uns } \\
\text { Asien }\end{array}$ & liegt die Türkei, & dem in füden ist. \\
\hline
\end{tabular}

\section{$\underline{\text { Stufe D }}$}

Schreiben Sie einen Text (freies Thema), in dem mindestens 5 Relativsätze ercheinen (ca. 150 Wörter).

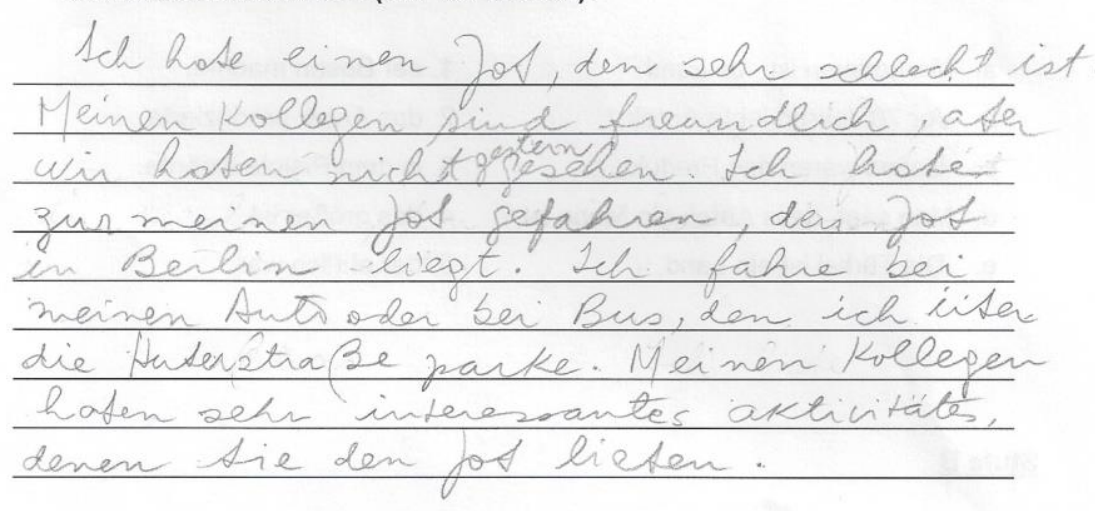




\section{Anexo 3: Questionário de perfil}

\section{QUESTIONÁRIO - Pesquisa de mestrado de}

A sua participação é anônima e a referência às informações aqui contidas também será feita anonimamente. Você autoriza expressamente a utilização dessas informações numa dissertação de mestrado. Você tem a opção de se negar a continuar participando da pesquisa e de negar a utilização de seus dados em qualquer fase do experimento. Muito obrigado pela colaboração!

1) Qual a sua idade? anos.

2) Qual a sua profissão? -

Trabalha em multinacional alemã? ( ) sim ( ) não

Se estudante, em qual ( ) escola ou ( ) universidade? -

3) Seu primeiro contato com a língua alemã foi:

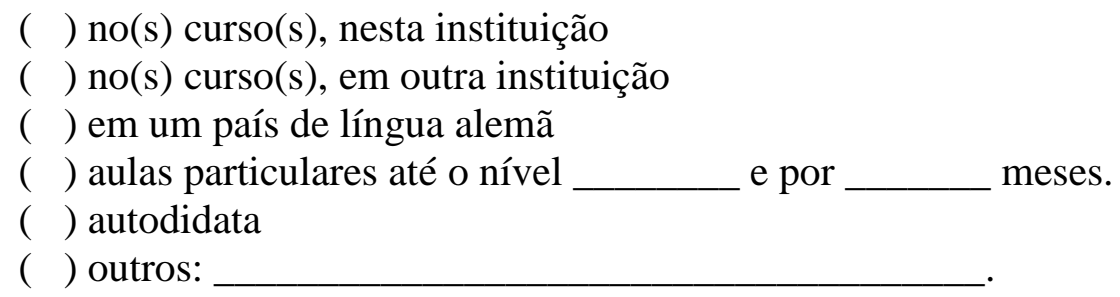

4) Desde que curso, semestre e ano você estuda nesta instituição?

Curso: Ano: Semestre: 
5) O que você almeja conseguir mediante o estudo da língua alemã?

6) Seu interesse pela língua alemã está relacionado a:

( ) necessidades ou questões de ordem acadêmica

( ) necessidades ou questões de ordem profissional

( ) hobby ou gosto por aprender línguas

( ) outro(s) motivo(s):

Muito obrigado! 


\section{Rund ums Essen}

Beruf Restaurantfachfrau

a) Lesen Sie den Text und beantworten Sie die Fragen.

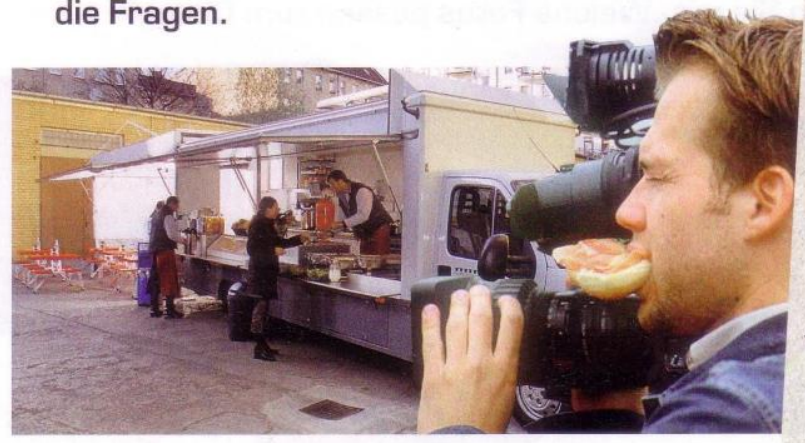

Lena, 21, Restaurantfachfrau Lena hat ihre Ausbildung bei einer Cateringfirma gemacht. Die Firma organisiert das Essen für Filmteams, 5 die in Köln Filme machen. Lena hat bei der Menüwahl und beim Einkaufen geholfen. In der Ausbildung musste sie auch kochen, Geschirr spülen, servieren, Speisekarten 10 schreiben und Tische decken. Lenas Arbeitsort war der große Cateringwagen. Die Ausbildung hat zwei Jahre gedauert. Lena hatte viele Kontakte zu den Schauspielern.

1. Wo hat Lena ihre Ausbildung gemacht?

2. Wie lange hat die Ausbildung gedauert?

3. Wo hat Lena gearbeitet?

4. Welche Aufgaben hat eine Restaurantfachfrau?

b) Hören Sie das Interview mit Lena. Welche Informationen sind neu?

Relativsätze: Personen oder Sachen genauer beschreiben. Ordnen Sie zu.

\section{Hauptsatz}

Eine Restaurantfachfrau ist eine Frau, 1 Ein Koch ist ein Mann, 2

Kaffee ist ein Getränk, 3

Küchenhilfen sind Leute, 4 .

\section{Relativsatz}

a der für Gäste im Restaurant kocht.

b das in Deutschland sehr beliebt ist.

c die die Gäste im Restaurant berät.

d die dem Koch in der Küche helfen.

3 Was ist das? Ergänzen Sie die Relativpronomen.

1. Eine After-Work-Party ist eine Party, gleich nach der Arbeit beginnt.

2. Ein „Gespritzter“ ist in Österreich ein Getränk, Mineralwasser besteht.

3. Restaurantkritiker sind Journalisten, Essen im Restaurant testen.

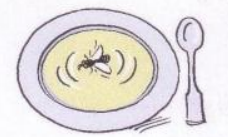
aus Apfelsaft und Herr Ober, was ist das?

4. Ein griechischer Bauernsalat ist ein Salat, Käse und Zwiebeln besteht. aus Tomaten, Gurken, Paprika,

Das ist eine Fliege, in Ihrer Suppe schwimmt.

\section{Regeln. Ordnen Sie zu.}

Latte Macchiato ist ein Getränk, das aus Milch und Kaffee besteht.

Der Relativsatz ist ein Nebensatz. Das Verb steht am Ende.

Der Relativsatz erklärt ein Nomen im Hauptsatz.

Das Relativpronomen steht nach dem Komma. 
5 Relativsätze in der Satzmitte. Lesen Sie das Beispiel. Schreiben Sie die Sätze.

Der Koch: Er arbeitet im Restaurant „Krone“. Er macht die besten Schnitzel in der Stadt.

Der Koch, der im Restaurant "Krone" arbeitet, macht die besten Schnitzel in der Stadt.

1. Die Restaurantfachfrau: Sie hat gerade ihre Ausbildung beendet.

Sie arbeitet bei einer Cateringfirma.

2. Die Journalistin: Sie hat einen Restaurantskandal aufgedeckt.

Sie schreibt für die „Frankfurter Rundschau“.

3. Der Kellner: Er bringt die Karte. Er ist sehr freundlich.

\section{Spezialitäten: Wie macht man das?}

a) Relativpronomen im Akkusativ. Lesen Sie das Beispiel und vergleichen Sie die Sätze.
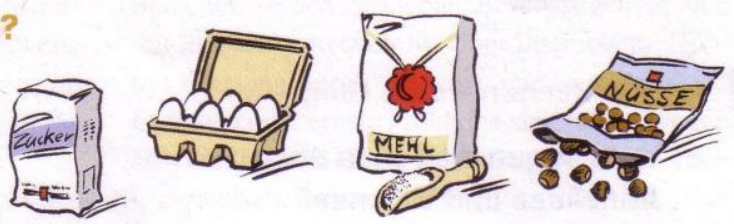

Baklava: ein türkischer Kuchen; aus Mehl, Wasser, Nüssen und Zucker.

Baklava ist ein türkischer Kuchen. Man macht den Kuchen aus Mehl, Wasser, Nüssen und Zucker.

Baklava ist ein türkischer Kuchen, den man aus Mehl, Wasser, Nüssen und Zucker macht).

b) Beschreiben Sie wie in Aufgabe a).

Toast Hawaii: ein Toast; aus Toastbrot, Schinken, Ananas und Käse Sushi: eine japanische Spezialität; aus Reis, Gemüse und Fisch Käse-Fondue: ein Schweizer Gericht; aus Käse, Wein und Brot Tsatsiki: eine griechische Soße; aus Joghurt, Gurke und Knoblauch Frankfurter: Würstchen; aus Schweinefleisch

c) ... und was sind Wiener, Amerikaner, Kameruner und Krakauer? Recherchieren Sie. Beschreiben Sie im Kurs.

d) Und Ihre Spezialität? Berichten Sie.

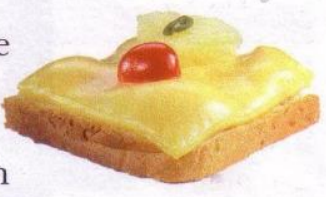

Logisch, oder? Lesen Sie im Kurs.

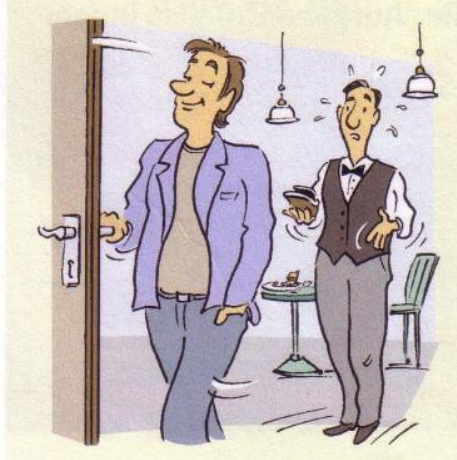

Der Kellner bringt dem Gast ein Stück Apfelkuchen. Der Gast schaut sich das Stück Kuchen kurz an und sagt zum Kellner: „Ich hätte doch lieber ein Stück Erdbeerkuchen. “Der Kellner bringt ihm den Erdbeerkuchen. Der Gast isst den Erdbeerkuchen mit großem Appetit und will dann das Lokal verlassen.

Kellner: „Hey, Sie haben den Erdbeerkuchen noch nicht bezahlt!“ Gast:„Aber den hab ich doch für den Apfelkuchen bekommen!“ Kellner: „Den haben Sie aber auch nicht bezahlt!“ Gast:„Den hab ich ja auch nicht gegessen ..."

studio d A2; Kurs- und Arbeitsbuch - unidade 6 (KUHN et al., 2010a, p. 93) 


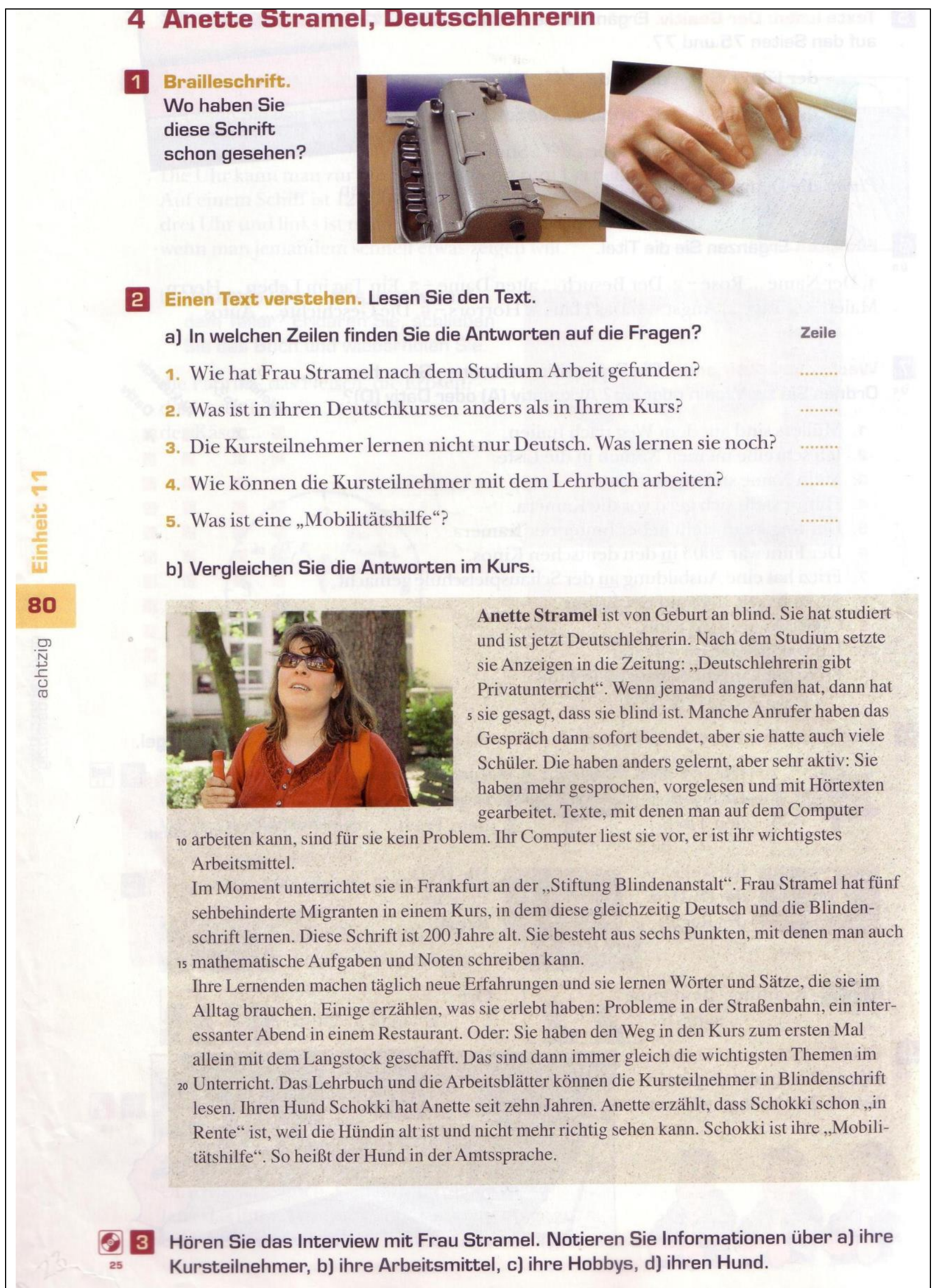

studio d A2; Kurs- und Arbeitsbuch - unidade 11 (KUHN et al., 2010, p. 80) 
Relativaátze: in, mit + Dativ

a) Markieren Sie den Relativsatz. Vergleichen Sie mit Einheit 6/3.

Der Kurs besteht aus fünf Migranten. Frau Stramel arbeitet im Moment in dem Kurs.

Der Kurs, in dem Frau Stramel im Moment arbeitet, besteht aus fünf Migranten.

Das Lehrbuch ist in Brailleschrift übertragen. Sie arbeiten mit dem Lehrwerk im Kurs.

Das Lehrbuch, mit dem sie im Kurs arbeiten, ist in Brailleschrift übertragen.

Die Schrift ist 200 Jahre alt. Mit ihr kann man auch Noten schreiben.

Die Schrift, mit der man auch Noten schreiben kann, ist 200 Jahre alt.

Die Rãume sind groß und haben Internetanschluss. Sie arbeiten in den Räumen.

Die Răume, in denen sie arbeiten, sind groß und haben Internetanschluss.

\section{b) Ergänzen Sie die Tabelle.}

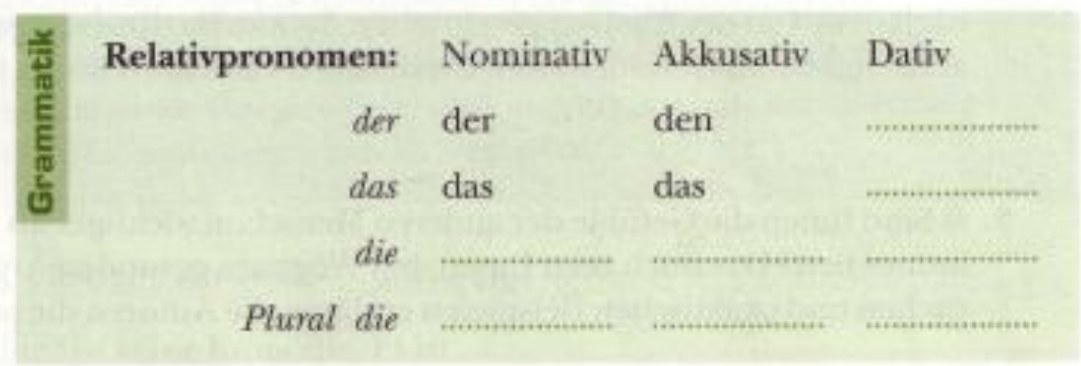

5 Wünsche und Ideale. Beschreiben Sie.

Deutschkurs: Es gibt nur nette Teilnehmerinnen.

Lehrbuch: Es gibt nur interessante Texte.

Lehrerin: Sie macht viele Projekte mit uns.

Der ideale Deutschkurs ist ein Kurs, in dem.

Urlaub:... - Auto: ... - Partner: ...

Hören und sehen in Redewendungen. Zweimal sehen, zweimal hören - welche Sätze passen zu welcher Redewendung? Ordnen Sie zu und lesen Sie vor.

1. Unsere Firma hat jetzt drei harte Jahre und viele Probleme gehabt. Aber ich sehe Licht am Ende des Tunnels.

3. Gestern hat unser Personalchef gesagt, dass wir drei Leute zu viel sind. Man konnte eine Stecknadel fallen hören.

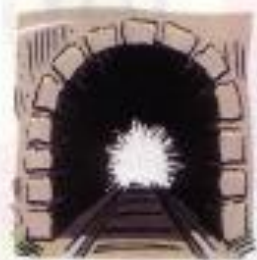

2. Meine neue Kollegin kritisiert mich jeden Tag dreimal. Ich sehe schon rot, wenn sie in den Raum kommt.
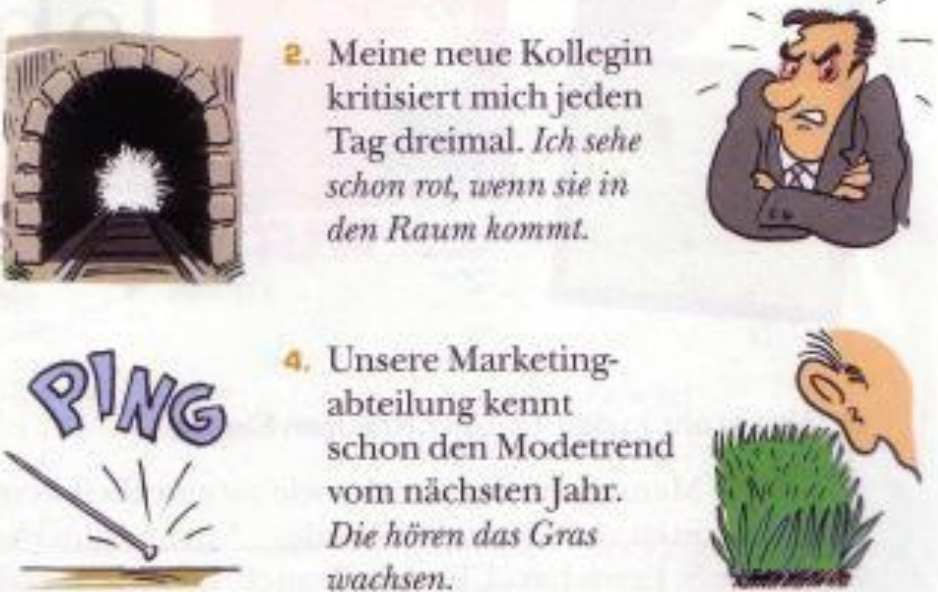

4. Unsere Marketingabteilung kennt schon den Modetrend vom nächsten Jahr. Die hören das Gras wachsen.

a) Ich bin jetzt ein bisschen optimistischer für die Zukunft.

b) Niemand hat etwas gesagt. Es war ganz ruhig.

c) $\mathrm{Er} / \mathrm{Sie}$ hat / Sie haben einen guten Sinn für neue Entwicklungen.

d) Ich werde sofort wūtend, wenn er/sie kommt. 


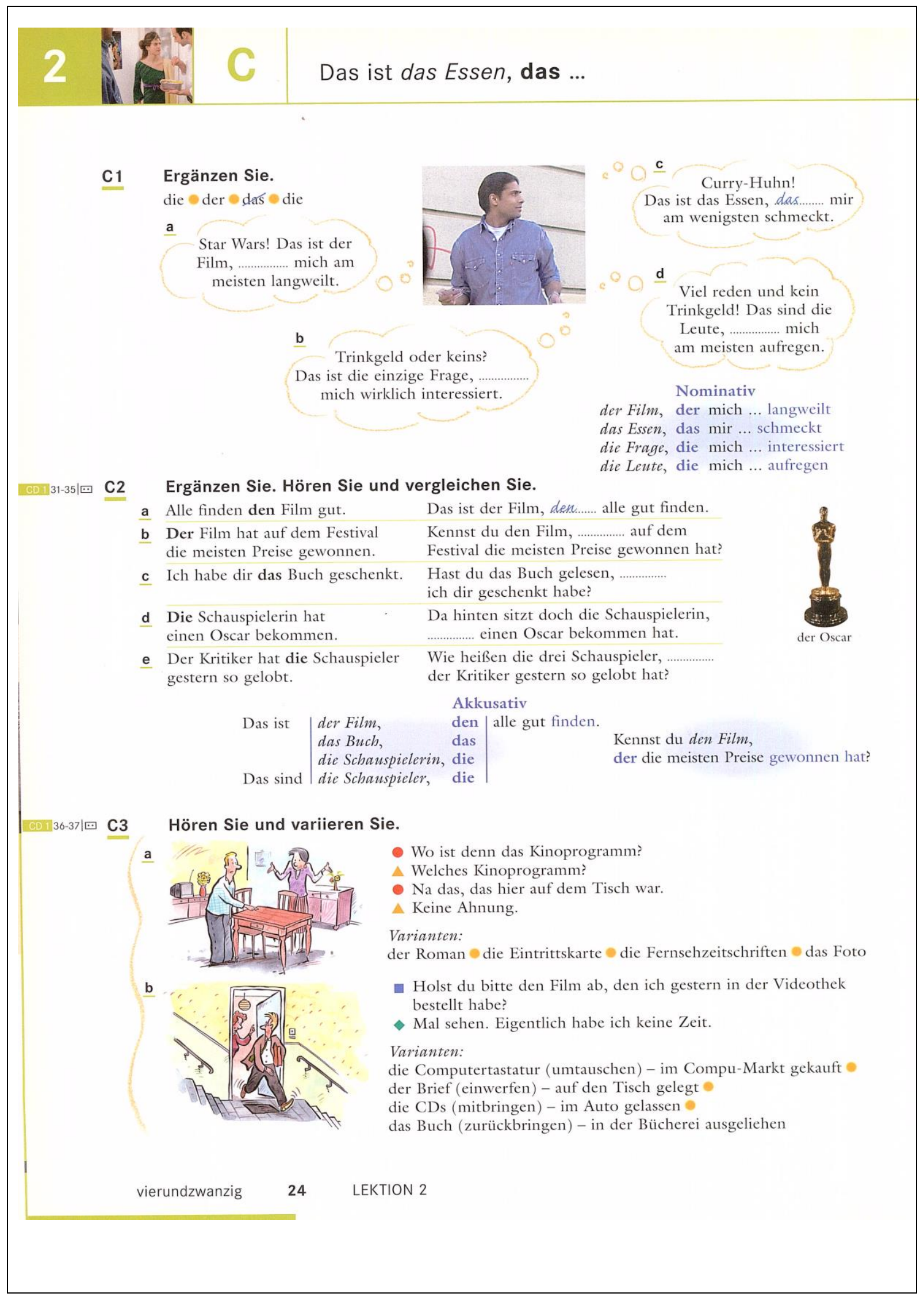

Schritte International 5; Kursbuch + Arbeitsbuch - lição 2 (HILPERT et al., 2011, p. 


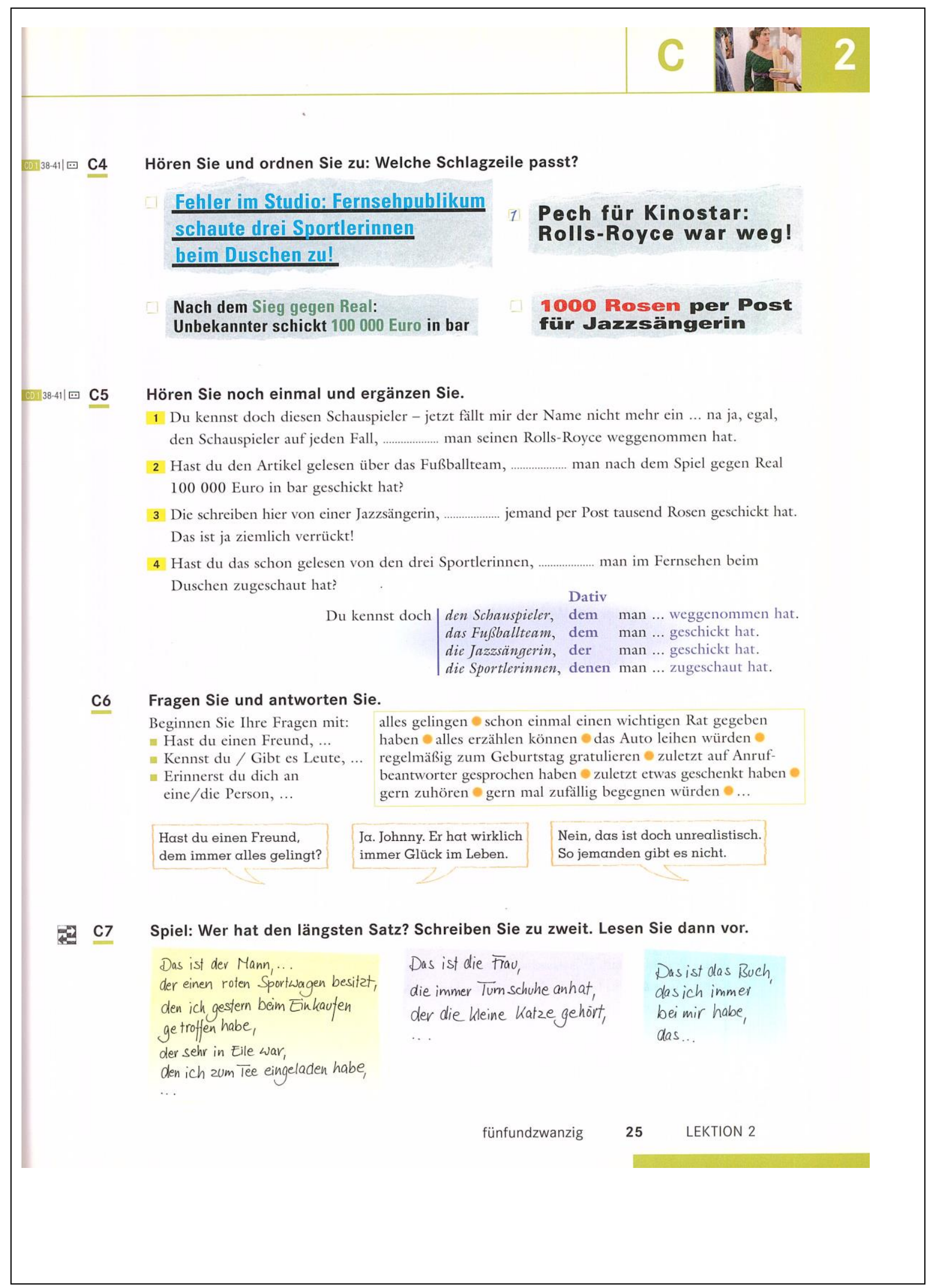

Schritte International 5; Kursbuch + Arbeitsbuch - lição 2 (HILPERT et al., 2011, p.

25) 


\section{Grammatik}

1 Konjunktion: obwohl

Bettina soll das Essen bezahlen,

(Bettina soll das Essen bezahlen.)

\section{Konjunktion}

obwohl sie keinen Hunger

(Sie hat keinen Hunger.)

2 Relativpronomen und Relativsatz

maskulin

Nominativ

Akkusativ

Dativ

Das ist der Mann,

neutral

Nominativ

Akkusativ

Dativ

feminin

Nominativ

Akkusativ

Dativ

Plural

Nominativ

Akkusativ

Dativ

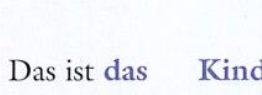

Das ist die Frau,

,

Männer

Das sind die Kinder,

Frauen,

\section{der}

den

dem

berühmt

ich gestern

ich alles

das berühmt

das ich gestern

dem ich alles

die berühmt

die

der

ich gestern

ich alles

berühmt

die

denen
Ende

hat.

$\left(\frac{10}{0}\right.$

\section{Gradpartikel}

\begin{tabular}{l|l} 
total $\bullet$ echt $\bullet$ wirklich $\bullet$ besonders $\bullet$ ziemlich $\bullet$ & langweilig/interessant/ ... \\
nicht so $\bullet$ nicht besonders $\bullet$ gar nicht $\bullet$ überhaupt nicht & nible
\end{tabular}

\section{Wichtige Wendungen}

\section{gegensätzliche Meinungen äußern}

Ich bin der Meinung, dass ... $\bullet \mathrm{Ja}$, das ist schon möglich, aber ...• Das können wir schon, obwohl ...• Ich mache ... lieber, weil ... $\bullet$ Glaubst du wirklich, dass ...? $\bullet$ Da irrst du dich aber gewaltig.

\section{sich nach Personen erkundigen und diese beschreiben}

Hast du einen Freund, dem ...?• Kennst du Leute, denen ...?• Gibt es / Erinnerst du dich an eine Person, der ...?

\section{ablehnen / einen Gegenvorschlag machen}

Du weißt doch, $\ldots \bullet$ Das möchte ich wirklich nicht. •

Das kommt für mich nicht in Frage. •

Ich würde (doch) lieber ... einen Konsens suchen

\section{und finden}

Wir könnten doch ...•

Wie wäre es, wenn ...?•

Lasst uns doch ...•

Wir sollten ...• Ich finde ...•

Das ist doch viel besser als ...

Findest du nicht? •

Genau! • Natürlich!•

Da hast du völlig recht. •

Das finde ich auch.•

Gut, dann ... Einverstanden! •

In Ordnung!

\section{das Wort ergreifen}

Darf ich auch mal was sagen?• Jetzt rede ich. 
